Review

\title{
Asymmetric Synthesis of Naturally Occuring Spiroketals
}

\author{
B. Rama Raju and Anil K. Saikia * \\ Department of Chemistry, Indian Institute of Technology Guwahati, Guwahati 781039, India \\ E-mail: rajchem44@gmail.com
}

* Author to whom correspondence should be addressed; E-mail: asaikia@iitg.ernet.in.

Received: 21 July 2008; in revised form: 22 August 2008 / Accepted: 22 August 2008 / Published: 28 August 2008

\begin{abstract}
Spiroketals are widely found as substructures of many naturally occurring compounds from diverse sources including plants, animals as well as microbes. Naturally occurring spiroketals are biologically active and most of them are chiral molecules. This article aims at reviewing the asymmetric synthesis of biologically active spiroketals for last 10 years (1998-2007).
\end{abstract}

Keywords: Synthesis; Asymmetric; Natural product; Spiroketal

\section{Introduction}

Spiroketals occur in Nature as subunits of miscellaneous natural products and are found in microbes, fungi, plants, insects and marine organisms. Spiroketals are cyclic ketals in which two rings are joined by a single atom, the spiro atom, and the two ketal oxygens flanking the spiro atom, each belonging to one of the rings. The spiroketal ring system exists in a wide variety of natural products of varying complexity. Most of the naturally occurring spiroketals are biologically active compounds [13], such as, for example, the reveromycins [4, 5], which contains spiroketal skeletons, and are inhibitors of the mitogenic activity of epidermal growth factor. Similarly, the cephalostatins are highly potent cell growth inhibitors $[6,7]$. Moreover, the telomerase-inhibiting activity of griseorhodin and rubromycin is attributed to the presence of a spiroketal moiety in these natural products $[8,9]$. Various spiroketals from insects are volatile, simple molecules and act as pheromones [10]. Over years, these natural products have become important synthetic targets not only for the challenges they present but also because of their pharmacological importance. 
The major challenge frequently encountered in the asymmetric synthesis of spiroketals is the stereoselective assembly of the spirocyclic structure with a linking carbon atom, which usually is a sterogenic centre but can easily isomerize under mild acidic conditions. On the other hand the advantage is that most of the natural products possess the thermodynamically favored configuration and conformation of the spirocentre thus favoring ring closure under equilibrium conditions [11].

\section{Asymmetric Total Synthesis of Natural Spiroketals}

\subsection{Enantioselective Total Synthesis of Okaspirodiol}

Okaspirodiol (1) was isolated as a secondary metabolite from Streptomyces species Gö TS 19 [12]. Okaspirodiol readily isomerizes under mild acidic conditions to three additional isomers: 1a, 1b, and 1c (Figure 1). The six membered rings of all isomers possess a chair-like conformation with a sterically favored equatorial methyl group. Structures 1 and 1a, both having $(S)$-configuration at C-5, benefit from two anomeric effects because of the axial-quasi-axial arrangement of the spiro C-O bonds, and therefore are more stable than the other two $(R)$-configured isomers $\mathbf{1 b}$ and $\mathbf{1 c}$. On the other hand, natural product $\mathbf{1}$ is thermodynamically less stable than 1a, most probably due to the cis relationship between C-3 and C-4 substituents in 1. The hydrogen bond between C-4 hydroxyl group and O-6 also makes $\mathbf{1}$ and $\mathbf{1 a}$ more stable.

Figure 1. Structures of compounds 1, 1a-1c.

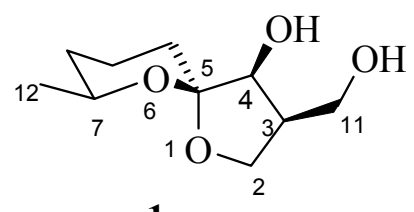

1

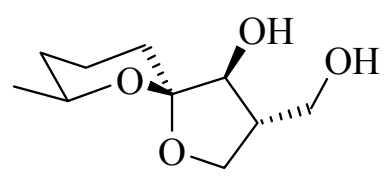

$1 \mathbf{a}$

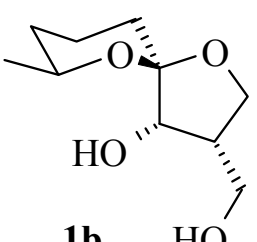

1b $\mathrm{HO}$

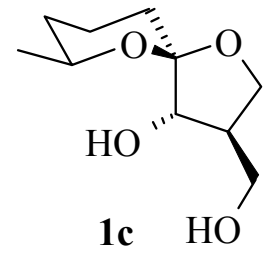

1c $\mathrm{HO}$

From the above discussions it is deduced that total synthesis of $\mathbf{1}$ from a spirocyclisation of an acyclic or monocyclic precursor under equilibrium conditions might be possible. Bender et al. have reported the total synthesis of okaspirodiol [12]. In this total synthesis, addition of a lithiated terminal alkyne bearing protected hydroxyl group to a lactone followed by hydrogenation of the triple bond and ring closure strategy is used $[13,14]$. The retrosynthetic pathway is shown in Scheme 1.

Scheme 1. Retrosynthetic analysis of okaspirodiol.
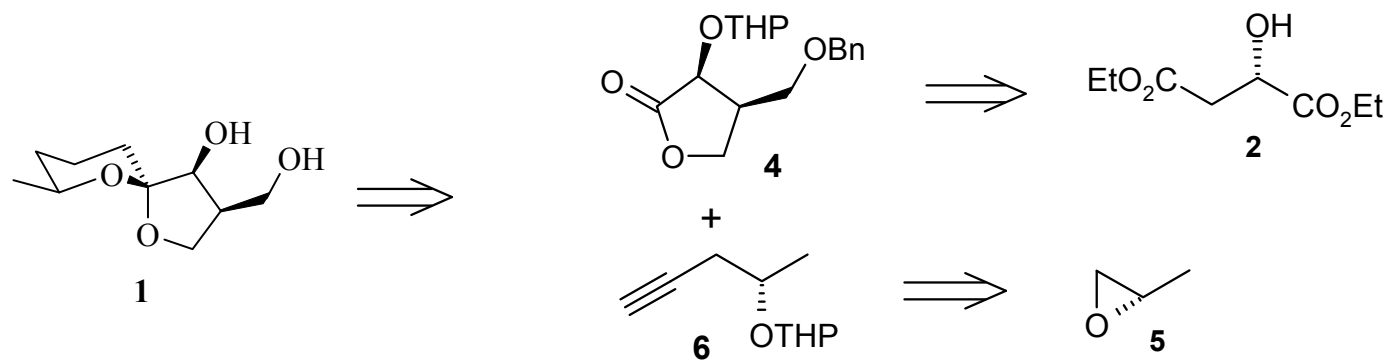
Both the fragments 4 and $\mathbf{6}$ are prepared separately according to known procedures and then combined in a later stage of the synthesis. Fragment 4 is prepared in eight steps and $53 \%$ overall yield starting from (S)-diethyl malate (2), according to known procedures (Scheme 2) $[15,16]$. Similarly, fragment 6 is prepared from $(S)$-propylene oxide (5) in three straightforward transformations giving the desired THP-protected, $(S)$-configured alkynol 6 in 58\% overall yield [17]. Compound 6 is then lithiated and added to the lactone 4 . The crude product 7 is treated with methanolic $\mathrm{HCl}$ to give the acetal 8, which is obtained as a single diastereomer with an $(R)$-configured anomeric carbon. Hydrogenation with $\mathrm{Rh} / \mathrm{Al}_{2} \mathrm{O}_{3}$ led to incomplete conversions, which resulted in the formation of the tricyclic diacetal $\mathbf{1 0}$ as a side product after cyclization [18]. This can be overcome using the Adams catalyst $\left(\mathrm{PtO}_{2}\right)$ in ethyl acetate, with carefully monitoring of the reaction by TLC to prevent the hydrogenation of the phenyl ring. During this process cyclization takes place to give the desired compound 9 as a single isomer. Finally, hydrogenolysis of the benzyl ether furnishes okaspirodiol.

Scheme 2. Synthesis of okaspirodiol.
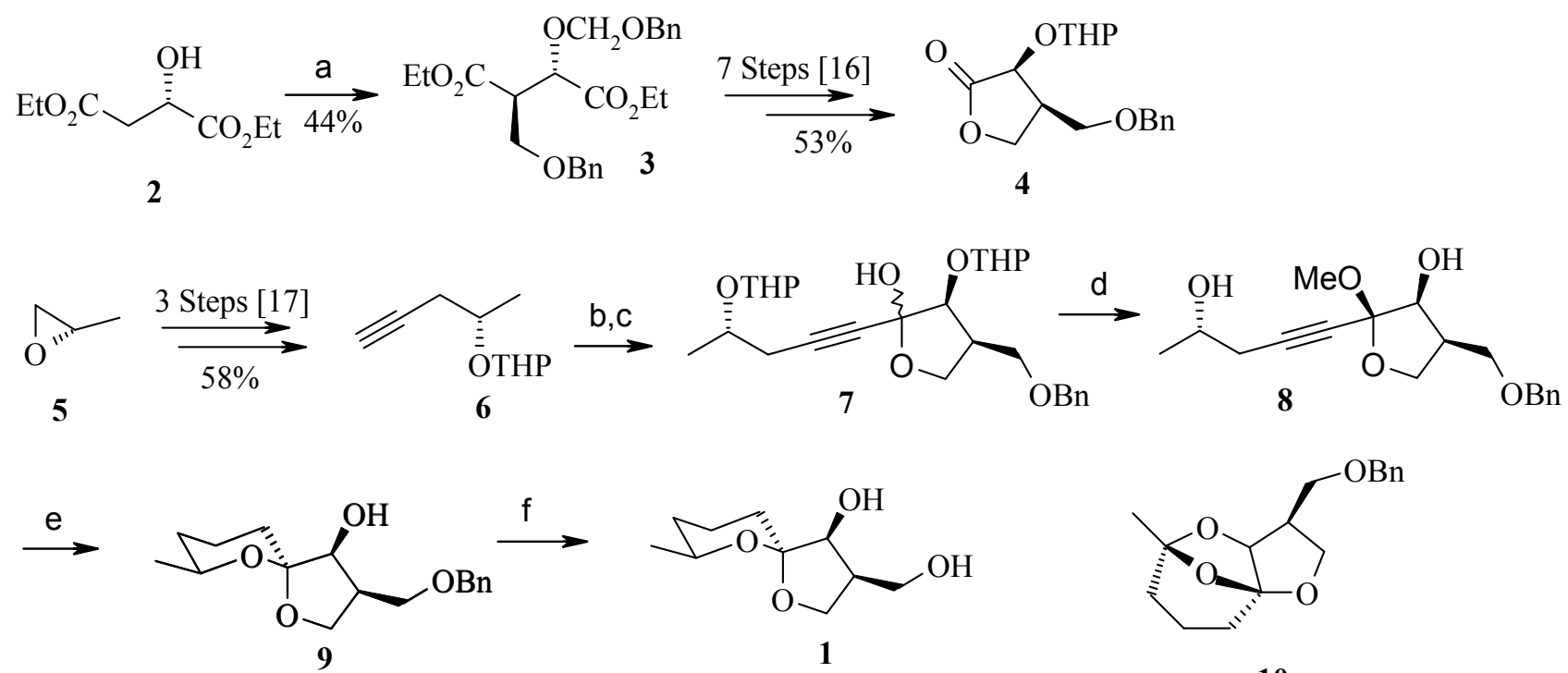

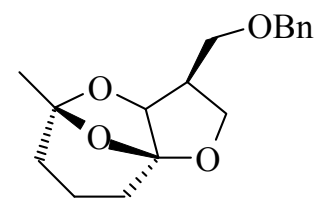

10

Reagents and conditions: (a) $\mathrm{LDA}, \mathrm{ClCH}_{3} \mathrm{OBn}, 44 \%$; (b) $\mathrm{MeLi}_{2} \mathrm{Et}_{2} \mathrm{O}, 0{ }^{\circ} \mathrm{C}$ (c) 4, $\mathrm{Et}_{2} \mathrm{O}, 0{ }^{\circ} \mathrm{C}$ to $\mathrm{rt}$; (d) $\mathrm{HCl}$, $\mathrm{MeOH}, \mathrm{rt}, 1 \mathrm{~h}$; (e) i) $\mathrm{H}_{2}, \mathrm{Rh} / \mathrm{Al}_{2} \mathrm{O}_{3}, \mathrm{MeOH}$, rt, ii) $\mathrm{HCl}, \mathrm{MeOH}$, rt or i) $\left.\mathrm{H}_{2}, \mathrm{PtO}_{2}, \mathrm{EtOAc}, \mathrm{rt}, \mathrm{ii}\right) \mathrm{CSA} \mathrm{CH}_{2} \mathrm{Cl}_{2}, \mathrm{rt}$; (f) $\mathrm{H}_{2}, \mathrm{Pd} / \mathrm{C}, \mathrm{MeOH}, \mathrm{rt}, 82 \%$.

\subsection{Enantiospecific synthesis of the heparanase inhibitor (+)-trachyspic acid and its stereoisomer} from a common precursor.

Trachyspic acid was isolated from the culture broth of Talaromyces trachyspermu SANK 12191 and was identified as a potent inhibitor of heparanase, with an $\mathrm{IC}_{50}$ of $36 \mu \mathrm{M}$ [19]. Heparanase is an endo- $\beta$-glucuronidase that cleaves the heparin sulfate (HS) side chains of proteoglycans that are found on cell surfaces and as a major constituent of the extracellular matrix (ECM) and basement membrane surrounding cells [20].

Rizzacasa and his coworkers have reported the enantiospecific synthesis of (+)-trachyspic acid and its stereoisomer [21]. The synthesis is based on the author's previous synthesis of (-)-trachyspic acid 
[22]. The retrosynthetic pathway of (-)-trachyspic acid is shown in Scheme 3. (-)-Trachyspic acid can be synthesized from the lactol precursor $\mathbf{1 1}$ by acid hydrolysis of the dioxalane and spirocyclisation of the resulting aldehyde, followed by lactol acetylation and ozonolysis of the terminal alkenes. Lactol 11 in turn can be synthesized from vinyl bromide 13 and lactone 12 that can be obtained from the 2deoxy-D-ribose derivative 14. Stereochemistry at C-3 is obtained by an Ireland-Claisen rearrangement performed on 14 in the presence of a $\beta$-leaving group [23]. On the other hand vinyl bromide 13 can be obtained from dimethyl malonate (15).

Scheme 3. Retrosynthetic analysis of (-)-trachyspic acid.

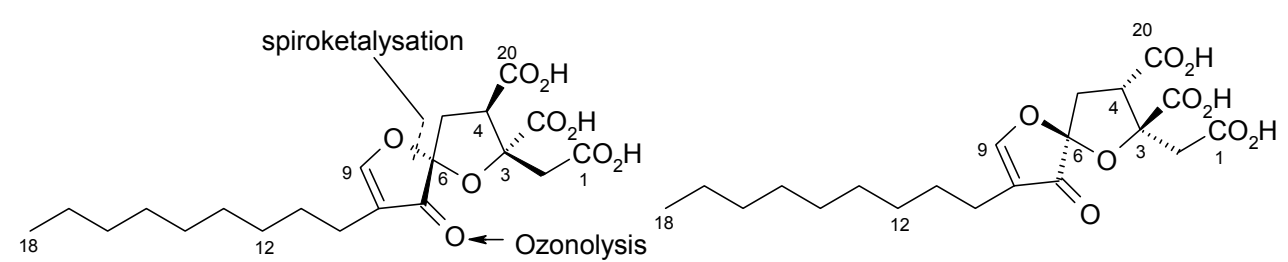

(-)-Trachyspic acid

$\downarrow$

(+)-Trachyspic acid

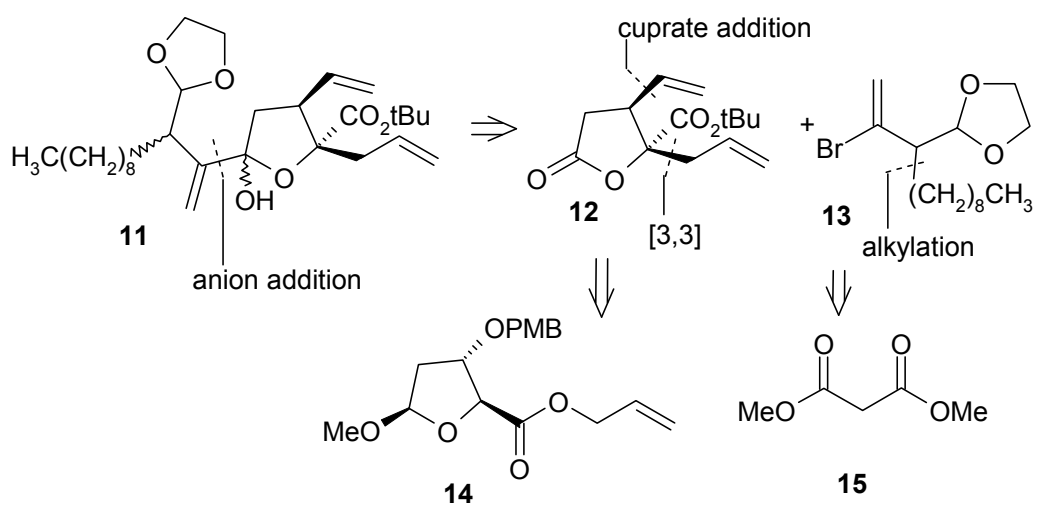

The fragment $\mathbf{1 4}$ is prepared as the corresponding $p$-methoxybenzyl (PMB) ether from known alcohol $\mathbf{1 6}$ in good yield in four steps (Scheme 4) [24]. Ireland-Claisen rearrangement of 14 followed by hydrolysis and esterification gives the $t$-butyl ester $\mathbf{1 8}$ as a single isomer [23].

The Claisen adduct is subjected to acid hydrolysis to afford a lactol, and then is oxidized to the lactone 19. Lactone $\mathbf{1 9}$ is converted to the $\alpha, \beta$-unsaturated lactone 20, which is subjected to conjugate addition with vinylmagnesium bromide in the presence of $\mathrm{CuI}$ and $\mathrm{Me}_{2} \mathrm{~S}$ to give two-alkene isomers 21 and 12, with a slight preference for isomer 21, which turned out to have the incorrect relative stereochemistry [25]. This is confirmed by the conversion of $\mathbf{1 2}$ into the crystalline tri-tert-butylester 22 by double ozonolysis, oxidation and ester formation.

Alkylation of dimethylmalonate $\mathbf{1 5}$ followed by reduction and monoprotection give the tert-butyldiphenylsilyl (TBDPS) ether 25 [26, 27]. Oxidation of the primary alcohol in $\mathbf{2 5}$ and Corey-Fuchs extension yields alkyne 26 [28]. From 26 the vinyl bromide 13 is obtained in four steps (Scheme 5).

Lithiation of 13 and then treatment with lactone 22 affords the lactol 11 along with some starting lactone 22. Acid induced cyclisation and acetylation of $\mathbf{1 1}$ followed by ozonolysis affords the desired $\alpha, \beta$-unsaturated spiroketal isomers 29 and 30, in a ratio of approximately 9:1 [29]. Treatment of 29 with TFA then gives (-)-ent-trachyspic acid (Scheme 6). 
Scheme 4. Synthesis of fragment 22.
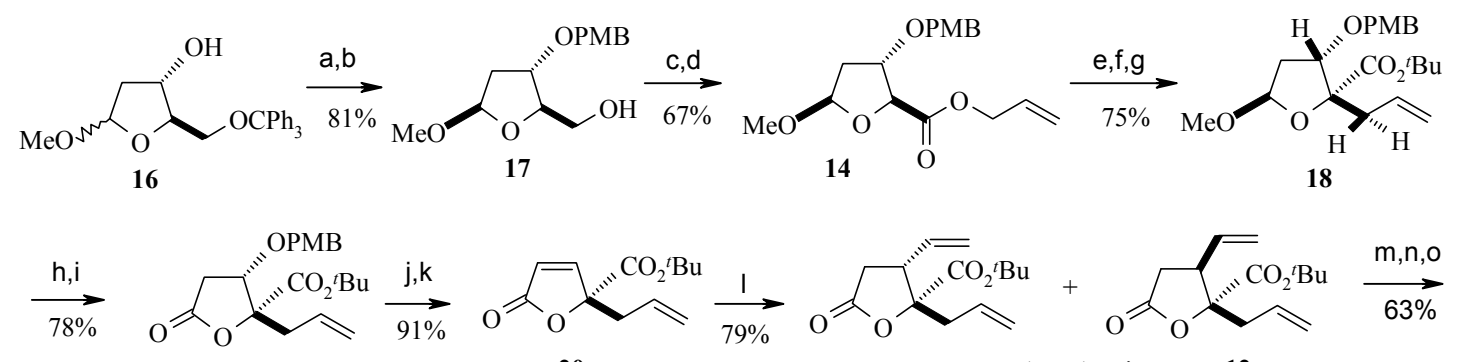

19

20

21

$1.5: 1$ ratio $\quad \mathbf{1 2}$

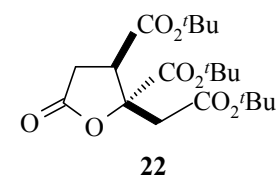

Reagents and conditions: (a) NaH, PMBCl; (b) $\mathrm{HCl}, \mathrm{MeOH}, 81 \%$; (c) $\mathrm{NaOCl}, \mathrm{NaClO}_{2}$, TEMPO; (d) DCC, DMAP, allyl alcohol, 67\%; (e) TMSCl-NEt 3 , LDA, THF-HMPA, $-95{ }^{\circ} \mathrm{C}$; (f) aq. $\mathrm{NaOH}$; (g) $N, N^{\prime}-$ diisopropyl-O-tert-butylisourea, 75\%; (h) HCl; (i) PCC, 78\%; (j) DDQ; (k) $\mathrm{MsCl}$, Py, 91\%; (l) CuI, vinylMgBr, $\mathrm{Me}_{2} \mathrm{~S},-45{ }^{\circ} \mathrm{C}, 79 \%$; (m) $\mathrm{O}_{3}, \mathrm{Me}_{2} \mathrm{~S}$; (n) $\mathrm{NaClO}_{2}, \mathrm{NaH}_{2} \mathrm{PO}_{4}$; (o) N,N'-diisopropyl-O-tertbutylisourea, $63 \%$.

Scheme 5. Synthesis of fragment 13.

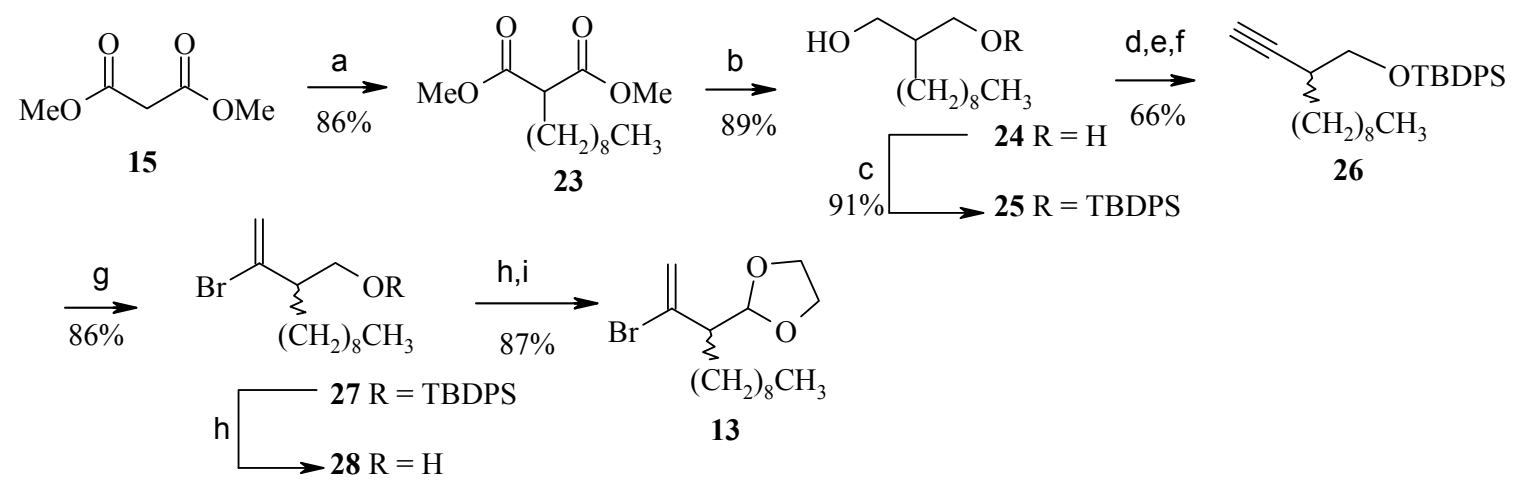

Reagents and conditions: (a) $\mathrm{NaOMe}$, nonyl bromide, $\mathrm{MeOH}$, reflux, $86 \%$; (b) $\mathrm{LiAlH}_{4}, 0{ }^{\circ} \mathrm{C}, 89 \%$; (c) $\mathrm{NaH}$, TBDPSCl, 91\%; (d) Dess-Martin reagent, (e) $\mathrm{Ph}_{3} \mathrm{P}, \mathrm{CBr}_{4}, 0{ }^{\circ} \mathrm{C}$; (f) $\mathrm{BuLi},-78{ }^{\circ} \mathrm{C}, 66 \%$; (g) $\mathrm{B}$-Br-9-BBN, $\mathrm{AcOH}, 0{ }^{\circ} \mathrm{C}, 86 \%$; (h) TBAF, $100 \%$; (i) Dess-Martin reagent; (j) $p$-TsOH, $\mathrm{HOCH}_{2} \mathrm{CH}_{2} \mathrm{OH}$, benzene, $87 \%$.

Scheme 6. Total synthesis of (-)-trachyspic acid.

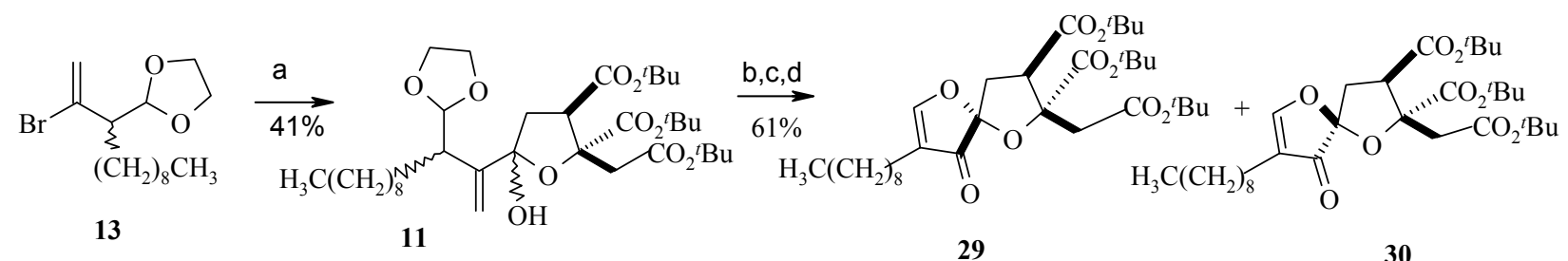<smiles>CCCCCCCCCCC1=COC2(OC(=O)O)CC(C(=O)O)[C@@](CC(=O)O)(O2)C1=O</smiles>

29 30

(-)-Trachyspic acid

Reagents and conditions: (a) $t$-BuLi, $\mathrm{Et}_{2} \mathrm{O}$-hexene, $-78{ }^{\circ} \mathrm{C}$, lactone 22; THF, 41\%; (b) $3 \mathrm{M} \mathrm{HClO}_{4}$, $\mathrm{THF}$; (c) $\mathrm{Ac}_{2} \mathrm{O}$, DMAP, Py; (d) $\mathrm{O}_{3}, \mathrm{NaHCO}_{3}, \mathrm{Me}_{2} \mathrm{~S}, 61 \%$; (e) TFA, $\mathrm{CH}_{2} \mathrm{Cl}_{2}, 99 \%$. 
For the synthesis of the enantiomer $(+)$-trachyspic acid, the lactone ent-22 is used. This can be obtained from the same deoxy-D-ribose derivative 16 used for the synthesis of $\mathbf{2 2}$. As the stereochemistry at C-4 is responsible for the stereochemistry of Ireland-Claisen rearrangement product at C-3, the inverted stereogenic center at C-4 in the precursor 31 would allow for the introduction of the $3 R$ stereochemistry required for the production of the natural $(+)$-trachyspic acid (Scheme 7).

Scheme 7. Proposed synthesis of ent-22.

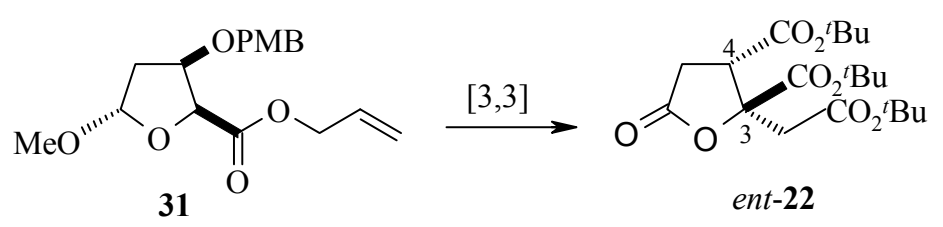

Scheme 8. Synthesis of ent-22 and (+)-trachyspic acid.

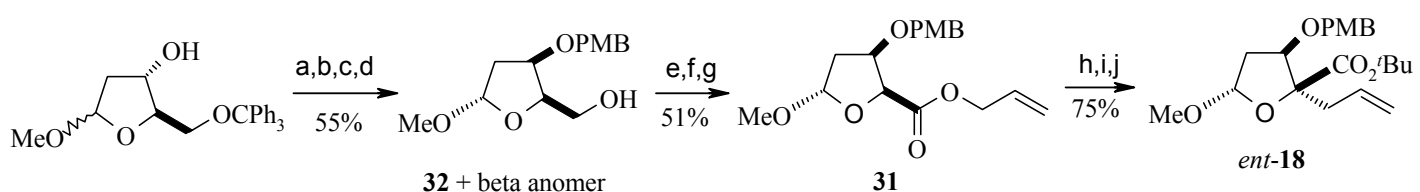

16

$32+$ beta anomer ent-18

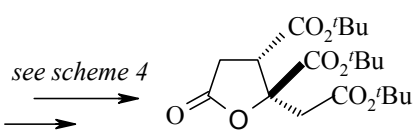

ent-22
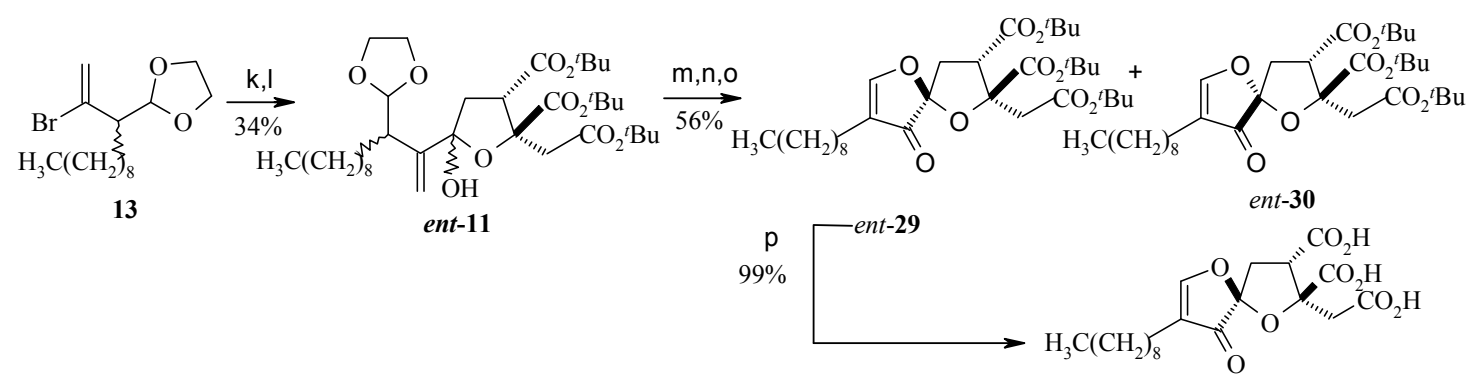

(+)-Trachyspic acid

Reagents and conditions: (a) $\mathrm{Ph}_{3} \mathrm{P}$, DIAD, $p$ - $\mathrm{NO}_{2} \mathrm{C}_{6} \mathrm{H}_{4} \mathrm{CO}_{2} \mathrm{H}$; (b) $\mathrm{K}_{2} \mathrm{CO}_{3}$, $\mathrm{MeOH}$; (c) $\mathrm{NaH}, \mathrm{PMBCl}$; (d) $10 \%$ $\mathrm{HCl}-\mathrm{MeOH}$; (e) Dess-Martin reagent; (f) $\mathrm{Ag}_{2} \mathrm{O}, \mathrm{KOH}$; (g) DCC, DMAP, allyl alcohol, 51\%; (h) TMSCl$\mathrm{NEt}_{3}$, LDA, THF-HMPA, $-95{ }^{\circ} \mathrm{C}$; (i) aq. $\mathrm{NaOH}$; (j) $N, N^{\prime}$-diisopropyl-O-tert-butylisourea, 75\%; (k) $t$-BuLi, $\mathrm{Et}_{2} \mathrm{O}-$ hexane, $-78{ }^{\circ} \mathrm{C}$; (1) lactone ent-22, THF, 34\%; (m) $3 \mathrm{M} \mathrm{HClO}_{4}$, THF; (n) $\mathrm{Ac}_{2} \mathrm{O}$, DMAP, Py; (o) $\mathrm{O}_{3}$, $\mathrm{NaHCO}_{3}, \mathrm{Me}_{2} \mathrm{~S}, 56 \%$; (p) TFA, $\mathrm{CH}_{2} \mathrm{Cl}_{2}, 99 \%$.

Modified Mitsunobu inversion of $\mathbf{1 6}$ and subsequent methanolysis, benzylation and trityl group hydrolysis affords 32, along with the corresponding $\beta$-anomer [30]. Oxidation of $\mathbf{3 2}$ and subsequent esterification gives allyl ester 31, which is subjected to Ireland-Claisen rearrangement and esterification to give ent-18. Repetition of the same sequence as done for $\mathbf{1 8}$ eventually gives ent-22. Addition of the anion derived from 13 to ent-22 gives a mixture of lactols, which on acid induced cyclisation and ozonolysis gives the spiroketals ent-29 and ent-30. Deprotection of ent-29 with TFA affords (+)-trachyspic acid (Scheme 8). 
2.3. Enantioselective total synthesis of the anti-Helicobacter pyroli agent $(+)$-spirolaxine methyl ether.

Spirolaxine and spirolaxine methyl ether are isolated from cultures of Sporotrichum laxum and phanerochaetepruinosum [31]. They have the inhibitory activity against the micro-aerophilic Gramnegative bacterium Helicobacter pylori and are therefore useful compounds for the treatment of gastroduodenal disorders and the prevention of gastric cancer. Spirolaxine methyl ether contain a 5,7dimethoxyphthalide nucleus linked to a 6,5-spiroacetal group by a five-membered methylene chain.

\subsubsection{Brimble Synthesis}

Brimble and her coworkers described the first enantioselective total synthesis of $(+)$-spirolaxine methyl ether [32]. The retrosynthetic pathway is shown in Scheme 9. This analysis shows that it is a union of aldehyde $\mathbf{3 3}$ and sulfone $\mathbf{3 4}$ by a modified Julia olefination. The phthalide aldehyde $\mathbf{3 3}$ can be obtained from lactonisation of $\mathbf{3 5}$, whereas the sulfone fragment $\mathbf{3 4}$ can be accessed from the protected trihydroxy ketone $\mathbf{3 6}$. Ketone $\mathbf{3 6}$ can be prepared from lithium acetylide $\mathbf{3 8}$ and aldehyde $\mathbf{3 7}$. The $(R)$ stereochemistry is obtained by using commercially available $(R)$-acetylide. The aldehyde 37 can be prepared from (L)-aspartic acid (39).

Scheme 9. Retrosynthetic analysis of $(+)$-spirolaxine methyl ether.

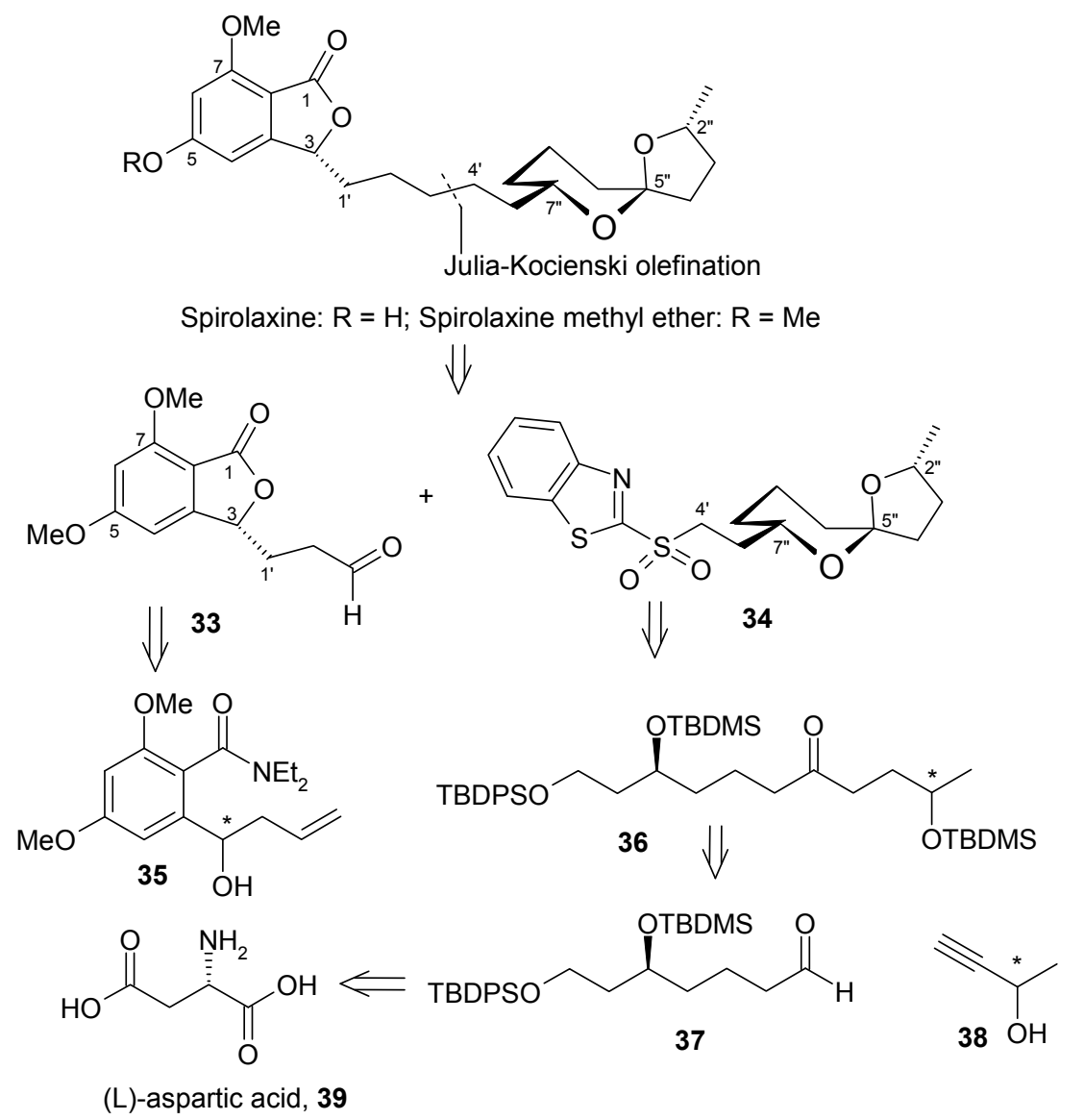


Synthesis of $(3 R)$-aldehyde $\mathbf{3 3}$ is achieved by initial synthesis of $(R)$-homoallyl alcohol from phthalide aldehyde 40 via titanium $(+)$-BINOL mediated asymmetric synthesis [33]. Regioselective bromination of the aromatic ring and subsequent diethylcarbamate formation followed by cyclisation gives compound $\mathbf{4 4}$, which on hydroboration and oxidation provides the desired phthalide aldehyde $\mathbf{3 3}$ (Scheme 10).

Scheme 10. Synthesis of phthalide aldehyde 33.
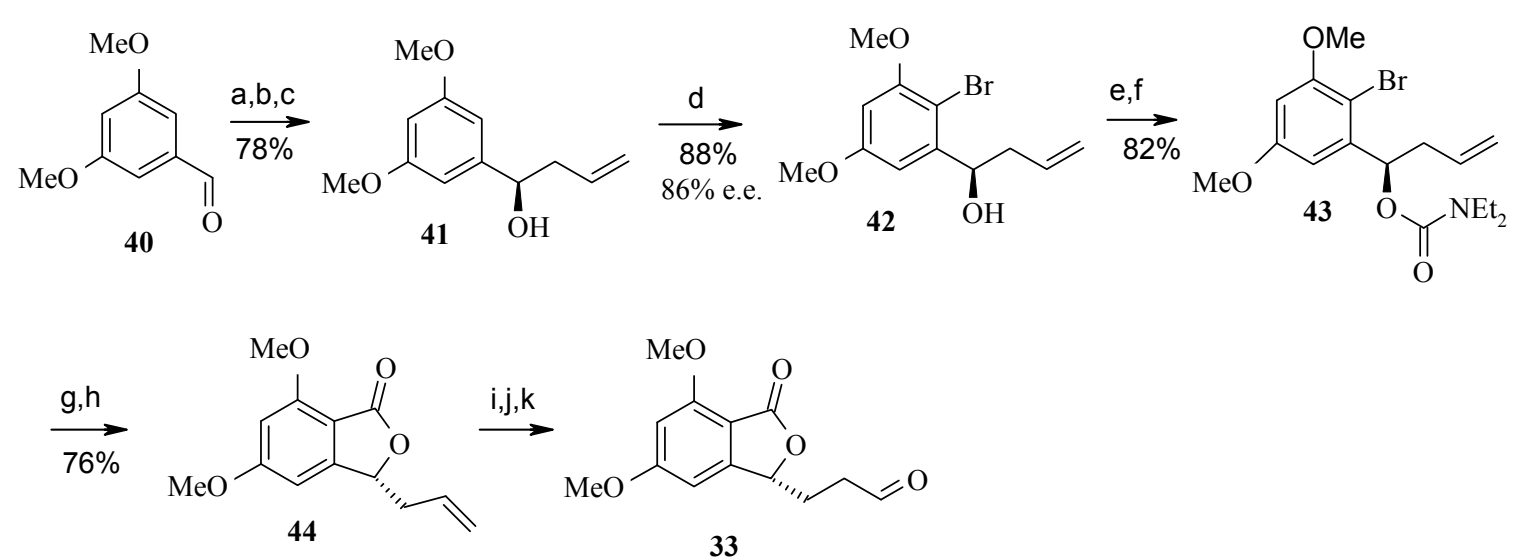

Reagents and conditions: (a) $\mathrm{TiF}_{4},(+)-\mathrm{BINOL}$; (b) allyltrimethylsilane, $\mathrm{CH}_{2} \mathrm{Cl}_{2}-\mathrm{MeCN}(97: 3),-20{ }^{\circ} \mathrm{C}$; (c) $n$ $\mathrm{Bu}_{4} \mathrm{NF}, 78 \%$; (d) NBS, $\mathrm{CHCl}_{3}, 88 \%$; (e) NaH, THF, $0{ }^{\circ} \mathrm{C}$; (f) $N, N^{\prime}$-diethylcarbamoyl chloride, $82 \%$; (g) $t$ BuLi, THF, $-78{ }^{\circ} \mathrm{C}$; (h) $p$-toluenesulfonic acid, $20{ }^{\circ} \mathrm{C}, 76 \%$; (i) $\mathrm{BH}_{3} . \mathrm{SMe}_{2}, \mathrm{THF}, 0{ }^{\circ} \mathrm{C}$; (j) $\mathrm{NaOH}, \mathrm{H}_{2} \mathrm{O}, \mathrm{H}_{2} \mathrm{O}_{2}$, $56 \%$; (k) PCC, Celite, $0{ }^{\circ} \mathrm{C}, 72 \%$.

The $(S)$-stereochemistry of the aldehyde $\mathbf{3 7}$ is installed in four steps by using $(R)$-epoxide $\mathbf{4 6}$, which provides the $(S)$-stereochemistry at C-7 of the spiroacetal ring. The epoxide 46 is obtained from Laspartic acid (39). Similarly, lithium $(R)$-acetylide 48 can be used to form C-2 of the spiroacetal ring with the desired $(R)$-stereochemistry [34]. Thus addition of aldehyde 37 to lithium acetylide $\mathbf{4 8}$ at -78 ${ }^{\circ} \mathrm{C}$ in the presence of lithium bromide provides alcohol 49 [35]. Oxidation of the alcohol to ketone followed by reduction of the acetylene, affords the protected trihydroxy ketone 50. Deprotection of the tert-butyldimethylsilyl ethers with camphorsulfonic acid also assists the spirocyclization, which on deprotection of the tert-butyldiphenylsilyl ether with tetrabutylammonium fluoride gives spiroacetal 51. The spiroacetal $\mathbf{5 1}$ is the major thermodynamically favored isomer due to its stabilization by the anomeric effect. The side chain alcohol is then converted to sulfone 34, which is then treated with phthalide aldehyde $\mathbf{3 3}$ to give olefin by using heterocycle-activated modified Julia olefination reaction $[36,37]$. Finally the olefin is carefully hydrogenated to give the spirolaxine methyl ether (Scheme 11).

\subsubsection{Dallavalle Synthesis}

Dallavalle and his coworkers have synthesized $(+)$-spirolaxine methyl ether by condensing phosphonate $\mathbf{5 2}$ and aldehyde $\mathbf{5 3}$ as shown in Scheme 12 [38]. In this case the spiroketal system is achieved by an oxidative cyclisation of hydroxyalkyl-substituted tetrahydropyran $\mathbf{5 5}$. The tetrahydropyran $\mathbf{5 5}$ itself is prepared from Prins cyclisation reaction, which gives all-cis stereochemistry [39]. 
The $(R)$-stereochemistry at C-7" of the spiroketal moiety is installed by synthesizing optically pure homoallylic $(R)$-alcohol 60 having side chains for the condensation with phosphonate 52. This compound is prepared from the reaction of aldehyde $\mathbf{5 8}$ and $\beta$-allyldiisopinocampenylborane $\mathbf{5 9}$ [40]. Aldehyde 58 is prepared from diol 56 by protection, deprotection and oxidation sequence from a known procedure by Brown (Scheme 13). The required stereochemistry at C-2" is obtained from the hemiacetal of 4- $(R)$-hydroxypentanal 61. Titanium tetrachloride mediated Prins cyclisation between 60 and 61 affords the 2,6-disubstituted-4-chlorotetrahydropyran 62 with the desired configuration [41].

Scheme 11. Total synthesis of (+)-spirolaxine methyl ether.

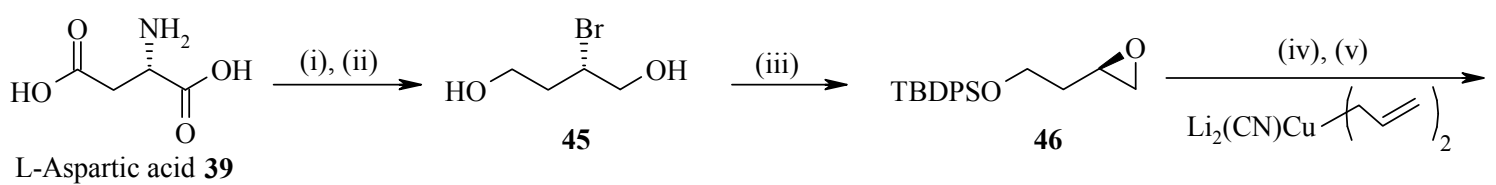

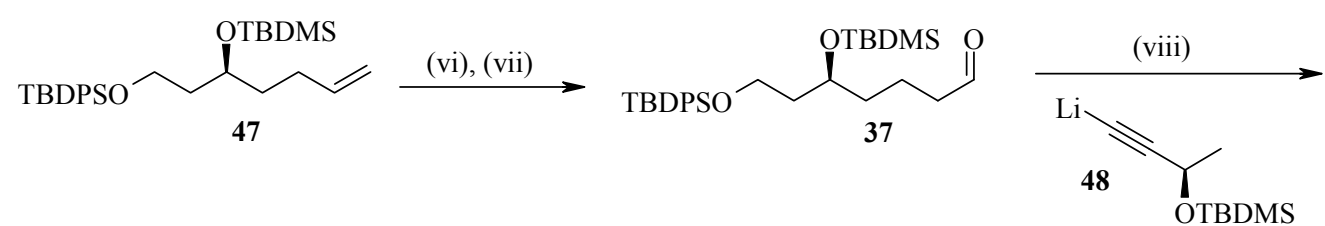

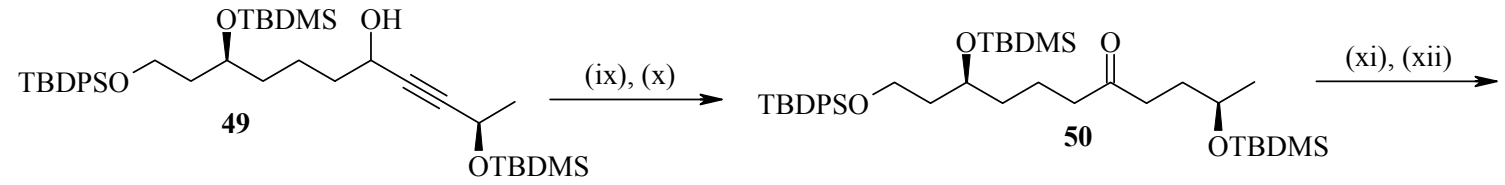<smiles>COc1cc(OC)c2c(c1)[C@@H](CCC=O)OC2=O</smiles>

(+)-Spirolaxine methyl ether

Reagents and conditions: (i) $\mathrm{NaNO}_{2}, \mathrm{KBr}, \mathrm{H}_{2} \mathrm{SO}_{4}, 0{ }^{\circ} \mathrm{C}, 2 \mathrm{~h}, 92 \%$; (ii) $\mathrm{BH}_{3} \cdot \mathrm{SMe}_{2}, \mathrm{THF}, 0{ }^{\circ} \mathrm{C}$ then $\mathrm{MeOH}$, 97\%; (iii) $\mathrm{NaH}$ (2equiv.), THF, $0{ }^{\circ} \mathrm{C}$ then TBDMSCl, 82\%; (iv) Cuprate, $\mathrm{THF},-78{ }^{\circ} \mathrm{C}, 2 \mathrm{~h}, 90 \%$; (v) TBDMSCl, imidazole, DMAP, $\mathrm{CH}_{2} \mathrm{Cl}_{2}, 98 \%$; (vi) $\mathrm{BH}_{3} . \mathrm{SMe}_{2}$, THF, $0{ }^{\circ} \mathrm{C}, \mathrm{NaOH}, \mathrm{H}_{2} \mathrm{O}_{2}, 83 \%$; (vii) DessMartin periodinane, pyridine, $\mathrm{CH}_{2} \mathrm{Cl}_{2}, 86 \%$; (viii) $\mathrm{LiBr}$, THF, $-78{ }^{\circ} \mathrm{C}, 76 \%$; (ix) TPAP, $\mathrm{NMO}, \mathrm{CH}_{2} \mathrm{Cl}_{2}, 78 \%$; (x) $\mathrm{H}_{2}, \mathrm{PtO}_{2}$, THF, 6h, 95\%; (xi) CSA, $\mathrm{CH}_{2} \mathrm{Cl}_{2}, 85 \%$; (xii) TBAF, THF, $0{ }^{\circ} \mathrm{C}, 83 \%$; (xiii) DEAD, $\mathrm{Ph}_{3} \mathrm{P}, 2-$ mercaptobenzothiazole; (xiv) $m$-CPBA, $\mathrm{CH}_{2} \mathrm{Cl}_{2}, 51 \%$ over two steps; (xv) LDA, THF, $-78{ }^{\circ} \mathrm{C}$ then aldehyde 33; (xvi) $\mathrm{PtO}_{2}, \mathrm{H}_{2}$, THF, 2h, 40\% over two steps. 
Scheme 12. Retrosynthetic analysis of $(+)$-spirolaxine methyl ether.<smiles>[R6]c1cc(OC)c2c(c1)[C@H](CCCCC[C@@H]1CCC[C@]3(CC[C@@H](C)O3)O1)OC2=O</smiles>

Spirolaxine: $\mathrm{R}=\mathrm{H}$; Spirolaxine methyl ether: $\mathrm{R}=\mathrm{Me}$<smiles>COc1cc(OC)c2c(c1)C(=O)OC2=O</smiles>

$\downarrow$

52<smiles>[R]CCCC[C@H]1CCC[C@]2(CC[C@@H](C)O2)O1</smiles><smiles>C[C@H](O)CC[C@H]1CCC[C@@H](CCCCCO)O1</smiles>

Scheme 13. Synthesis of homoallylic $(R)$-alcohol 60.

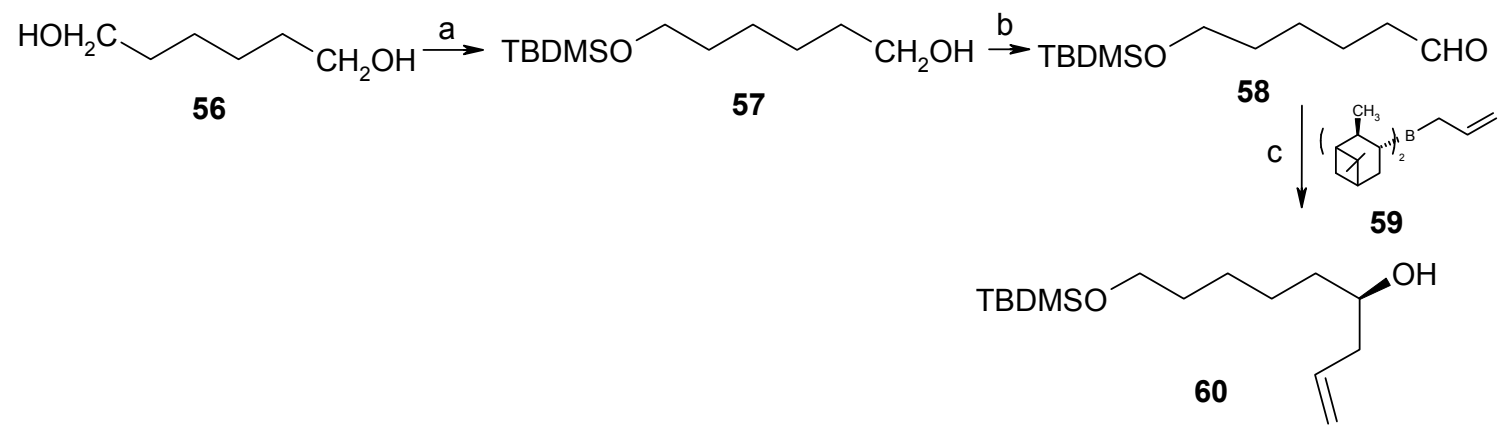

Reagents and conditions: (a) TBDMSCl, $\mathrm{Et}_{3} \mathrm{~N}, \mathrm{DMAP}, \mathrm{THF}, \mathrm{rt}, 18 \mathrm{~h}, 57 \%$, (b) $\mathrm{NaOCl}$, Polymer supported TEMPO, $\mathrm{KBr}, \mathrm{CH}_{2} \mathrm{Cl}_{2}, \mathrm{rt}, 6 \mathrm{~h}, 100 \%$, (c) (i) $\mathbf{5 9},-78{ }^{\circ} \mathrm{C}, 1 \mathrm{~h}$, then $1 \mathrm{~h}$ at rt, (ii) $\mathrm{NaOH}, \mathrm{H}_{2} \mathrm{O}_{2}(35 \%), 1 \mathrm{~h}$ of reflux, $82 \%$.

Reductive dechlorination and oxidative cyclisation gives the desired spiroketal $\mathbf{5 4}$ with low yield (21\%). This is overcome by selectively protecting the primary alcoholic group and subsequent oxidative cyclisation to give spiroketal 64 (Scheme 14). Deprotection of the hydroxyl group of 64 and subsequent oxidation gives aldehyde $\mathbf{5 3}$ for condensation with phosphonate $\mathbf{5 2}$. The phosphonate $\mathbf{5 2}$ is prepared by a literature procedure [42]. Condensation of phosphonate $\mathbf{5 2}$ with aldehyde $\mathbf{5 3}$ affords alkene $\mathbf{6 5}$ as a mixture of $E / Z$ isomers. Finally the synthesis is completed by reduction of double bond using $\mathrm{Pd} / \mathrm{C}$ as a catalyst, which led to a mxture of two stereoisomers from which the $(+)-$ spirolaxine methyl ether is separated by preparative HPLC. 
Scheme 14. Total synthesis of (+)-spirolaxine methyl ether.<smiles>C=CCC(O)CCCCCOC</smiles>

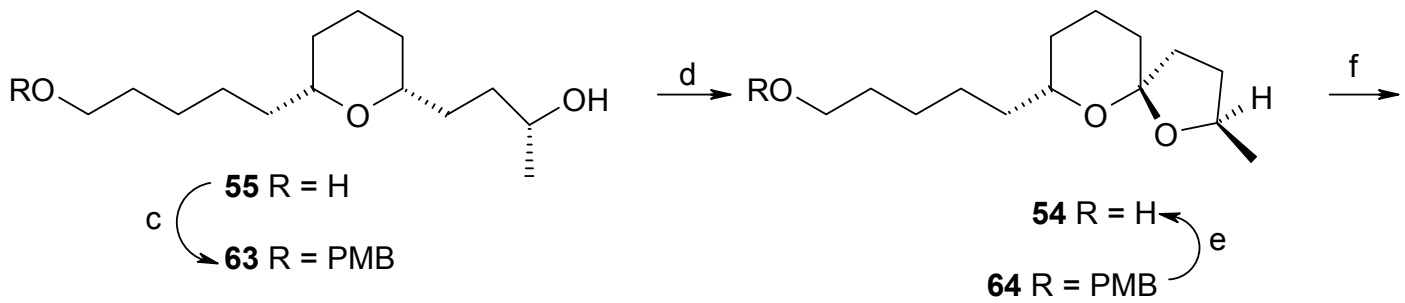<smiles>COc1cc(OC)c2c(c1)/C(=C/CCCC[C@H]1CCC[C@@]3(CCC(C)(C)O3)O1)OC2=O</smiles><smiles>COc1cc(OC)c2c(c1)[C@H](CCCCC[C@@H]1CCC[C@]3(CC[C@H](C)O3)O1)C(=O)O2</smiles>

(+)-Spirolaxine methyl ether

Reagents and conditions: (a) $\mathrm{TiCl}_{4}, \mathrm{CH}_{2} \mathrm{Cl}_{2},-70{ }^{\circ} \mathrm{C}, 4 \mathrm{~h}$, then $-20{ }^{\circ} \mathrm{C}, 1 \mathrm{~h}, 63 \%$, (b) $\mathrm{NaBH}_{4}$, DMSO, $130{ }^{\circ} \mathrm{C}$, 8h, 96\%, (c) PMBCl, NaH, DMF, rt, 3 days, 50\%, (d) $\mathrm{HgO}, \mathrm{I}_{2}, h v$, cyclohexane, 9h, 68\%, (e) CAN, $\mathrm{CH}_{3} \mathrm{CN} / \mathrm{H}_{2} \mathrm{O}$, rt, $2 \mathrm{~h}, 68 \%$, (f) TEMPO, KBr, NaOCl, 3h, 100\%, (g), 52, NaH, THF, rt, 24h, 62\%, (h) $10 \%$ $\mathrm{Pd} / \mathrm{C}, \mathrm{AcOH}, 4 \mathrm{~h}, 45 \%$.

\subsubsection{Phillips Synthesis}

Philips and coworkers applied cyclopropanol-based strategy for the subunit coupling as shown in Scheme 15 [43]. The synthesis starts with the coupling of readily available olefin 68 with commercially available $(R)-\gamma$-valerolactone $(67)$ to give cyclopropanol $\mathbf{6 6}$, according to the Kulinkovich cyclopropanation reaction [44]. Subsequent ring opening and deprotection gives spiroketal 51, which is then transformed into its bromide 70. Next, the bromide $\mathbf{7 0}$ is coupled with olefin 44 obtained from 40 by Brimble procedure (Scheme 16), using the alkyl-alkyl Suzuki coupling reported by Fu to give directly (+)-spirolaxine methyl ether (Scheme 17) [32, 45].

In all three approaches the coupling of two moieties, phthalide and spiroketal, gives the final products. The Brimble synthesis is longer than the Dallavalle and Phillips ones. The former consisting of 21 total steps, whereas the Dallavalle and Phillips syntheses consist of only 11 and 10 steps, respectively. The coupling of two moieties having all stereocenters makes these syntheses modular in nature, which opens up the utilization of these approaches for the synthesis of other diastereomers of 
spirolaxine methyl ether, paving the way for synthesis of analogs of these natural products for structure-activity studies.

Scheme 15. Retrosynthetic analysis of $(+)$-spirolaxine methyl ether.<smiles></smiles>

(+)-Spirolaxine methyl ether

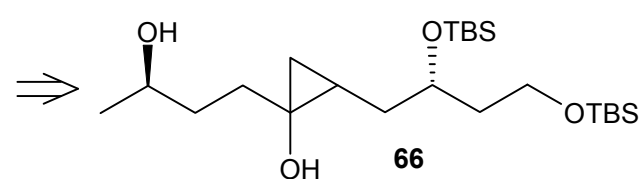<smiles>C[C@@H]1CCC(=O)O1</smiles>

67 $\downarrow$<smiles>C=CC[C@@H](CC[SeH])O[SbH3]</smiles>

68

Scheme 16. Synthesis of spiroketal bromide 70.<smiles>C=CC[C@@H](CC[OH+])O[SbH2]C(C)C</smiles><smiles>C[C@@H](O)CCC(=O)CCC[C@H](CC[SeH])O[SbH3]</smiles>

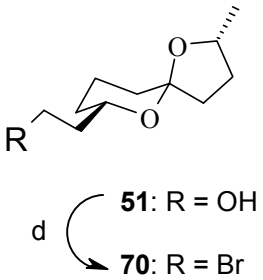

Reagents and conditions: (a) $c-\mathrm{C}_{6} \mathrm{H}_{11} \mathrm{MgBr}$, Ti(i-PrO) $)_{4}$, toluene, $92 \%$; (b) $\mathrm{Fe}\left(\mathrm{NO}_{3}\right)_{3}, \mathrm{Bu}_{3} \mathrm{SnH}$, DMF, 75\%; (c) $\mathrm{HF}, \mathrm{MeCN}, 89 \%$; (d) NBS, $\mathrm{Ph}_{3} \mathrm{P}, \mathrm{CH}_{2} \mathrm{Cl}_{2}, 99 \%$.

Scheme 17. Total synthesis of (+)-spirolaxine methyl ether.<smiles>CC=CCC(OC(=O)NCC)c1cc(OC)cc(OC)c1Br</smiles><smiles>C=CC[C@H]1OC(=O)c2c(OC)cc(OC)cc21</smiles>

(+)-Spirolaxine methyl ether

Reagents and conditions: (a) (-)- $\mathrm{Ipc}_{2} \mathrm{~B}$ (allyl), $\mathrm{Et}_{2} \mathrm{O}, 75 \%$ (b) $\mathrm{NBS}, \mathrm{CHCl}_{3}, 80 \%$; (c) $\mathrm{NaH}, \mathrm{Et}_{2} \mathrm{NCOCl}, \mathrm{THF}$, $82 \%$; (d) $t$-BuLi, THF, $p$-TsOH, 79\%; (e) 9-BBN, THF; (f) 70, aq. $\mathrm{Cs}_{2} \mathrm{CO}_{3}, \mathrm{Pd}(\mathrm{OAc})_{2}, \mathrm{Cy}_{3} \mathrm{P}$, dioxane, $40{ }^{\circ} \mathrm{C}$, $79 \%$. 
Dekker et al. isolated seven 5,7-dimethoxyphthalide antibiotics with specific anti-Helicobacter pylori activity from the basidiomycete Phanerochaete velutina CL6387 and out of these two more potent compounds were CJ-12,954 and its C-5" epimer CJ-13,014 (Figure 2) [46]. These are structurally related to the two helicobactericidal compounds spirolaxine and spirolaxine methyl ether [31].

\section{Figure 2. Structures of compounds CJ-12,954 and CJ-13,014.}

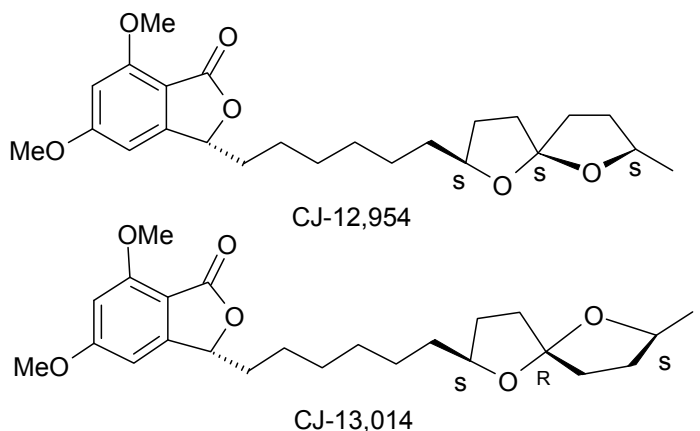

Brimble et al. first synthesized the anti-helicobacter pylori agents CJ-12,954 and CJ-13,014 based on the union of hetercycle-activated spiroacetal-containing sulfone fragment with a phthalidecontaining aldehyde fragment [47]. The key step in this synthesis is a modified Julia olefination of phthalide aldehyde and heterocycle-activated sulfones.

Scheme 18. Synthesis of phthalide aldehyde 77.<smiles>C=CC[C@H](O)c1cc(OC)cc(OC)c1Br</smiles><smiles>C=CCC1OC(=O)c2c(OC)cc(OC)cc21</smiles>

Reagents and conditions: (a) (R)-MeCBS, $\mathrm{BH}_{3}-\mathrm{SMe}_{2}, 15 \mathrm{~min}$, then THF, $2 \mathrm{~h}, 92 \%, 94 \%$ ee; (b) NBS, $\mathrm{NH}_{4} \mathrm{OAc}, \mathrm{Et}_{2} \mathrm{O}, 24 \mathrm{~h}, 90 \%$; (c) $\mathrm{NaH}, \mathrm{THF}, 0^{\circ} \mathrm{C}$, then $N, N$-diethylcarbamoyl chloride, $90 \%$, (d) $t$-BuLi, THF, $-78{ }^{\circ} \mathrm{C}$, 2h, then CSA, $20{ }^{\circ} \mathrm{C}, 12 \mathrm{~h}, 70 \%$, (e) 2-methyl-2-butene, $\mathrm{BH}_{3}-\mathrm{SMe}_{2}$, THF, $0{ }^{\circ} \mathrm{C}$, then $\mathrm{MeOH}, \mathrm{NaOH}$, $30 \% \mathrm{H}_{2} \mathrm{O}_{2}, 71 \%$; (f) TPAP, NMO, $\mathrm{CH}_{2} \mathrm{Cl}_{2}$, MS4A, $6 \mathrm{~h}, 20{ }^{\circ} \mathrm{C}, 72 \%$. 
At first the ketone $\mathbf{7 2}$ is reduced asymmetrically to give compound $\mathbf{7 3}$ with $(S)$-configuration [48]. This on regioselective bromination, diethylcarbamate formation and then lactonisation gives compound 76, which on hydroboration and subsequent oxidation affords the aldehyde 77 (Scheme 18). Next, the $(S)$-configuration at C-2" and C-7" is installed from $(S)$-homoallylic alcohol 79 and lithium $(S)$-acetylide derived from $\mathbf{8 2}$. Alcohol 79 is obtained from asymmetric reduction of aldehyde 78 [49]. Compound $\mathbf{7 9}$ is converted to aldehyde $\mathbf{8 1}$ by protection, hydroboration and oxidation steps.

Scheme 19. Synthesis of epi-CJ-12,954 and epi-CJ-13,014.
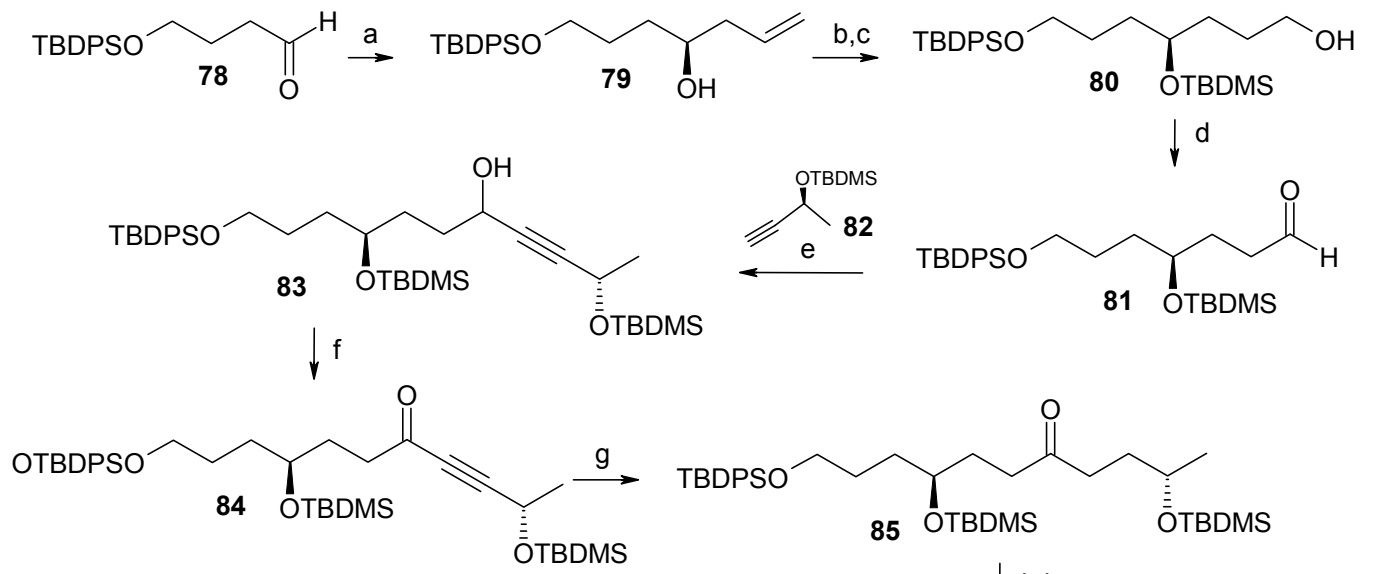

$\downarrow h, i$

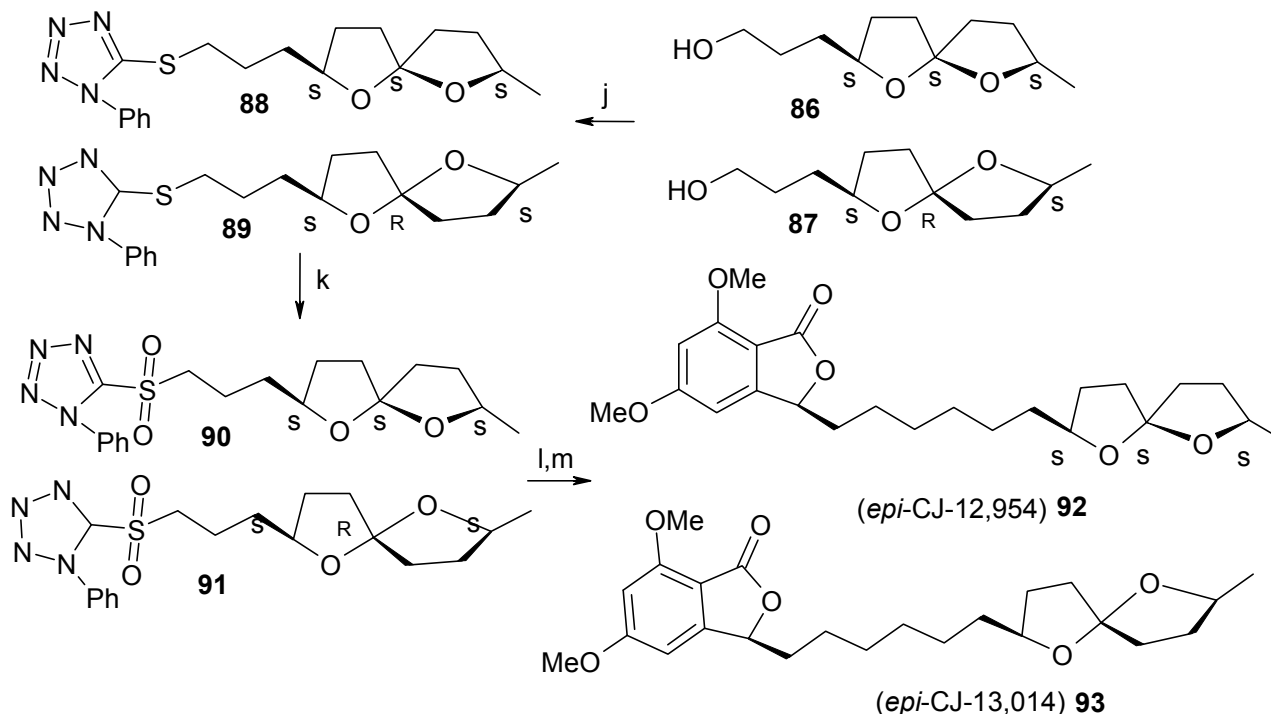

Reagents and conditions: (a) allyl bromide, $\mathrm{Mg},(+)-\beta$-diisopinocamphenylmethoxyborane, $\mathrm{Et}_{2} \mathrm{O},-78{ }^{\circ} \mathrm{C}$, 82\%, 94\% ee: (b) TBDMSCl, imidazole, DMAP, $\mathrm{CH}_{2} \mathrm{Cl}_{2}, 20{ }^{\circ} \mathrm{C}, 12 \mathrm{~h}, 90 \%$; (c) 2-methyl-2-butene, $\mathrm{BH}_{3}$ $\mathrm{SMe}_{2}, 0{ }^{\circ} \mathrm{C}, 76 \%$; (d) Dess-Martin periodinane, $\mathrm{Py}, \mathrm{CH}_{2} \mathrm{Cl}_{2}, 20{ }^{\circ} \mathrm{C}, 77 \%$, (e) 82, $n$-BuLi, LiBr, THF, $-78{ }^{\circ} \mathrm{C}$, then 81, 84\%; (f) TPAP, NMO, MS4A, $\mathrm{CH}_{2} \mathrm{Cl}_{2}, 20{ }^{\circ} \mathrm{C}, 94 \%$; (g) $\mathrm{H}_{2}, \mathrm{PtO}_{2}, \mathrm{~K}_{2} \mathrm{CO}_{3}$, THF-MeOH (1:1), 94\%, (h) $\mathrm{CSA}, \mathrm{CH}_{2} \mathrm{Cl}_{2}, 20{ }^{\circ} \mathrm{C}$, 4h, 93\%; (i) TBAF, $\mathrm{CH}_{2} \mathrm{Cl}_{2}, 20{ }^{\circ} \mathrm{C}, 3 \mathrm{~h}, 77 \%$; (j) 1-phenyl-1H-tetrazole-5-thiol, $\mathrm{Ph}_{3} \mathrm{P}, \mathrm{DEAD}, 78 \%$; (k) $m$-CPBA, $\mathrm{NaHCO}_{3}, 71 \%$; (l) KHMDS, THF, $-78{ }^{\circ} \mathrm{C}$ then 77, 84\%, (m) $\mathrm{H}_{2}, \mathrm{PtO}_{2}$, $\mathrm{K}_{2} \mathrm{CO}_{3}$, THF-MeOH (1:1), $85 \%$.

Reaction of aldehyde $\mathbf{8 1}$ with lithium acetylide 82, followed by oxidation with TPAP and NMO affords ketone 84, which is then selectively reduced to saturated ketone $\mathbf{8 5}$ using $\mathrm{PtO}_{2}$ as a catalyst 
(Scheme 19). Ketone $\mathbf{8 5}$ is then subjected to spirocyclisation with camphorsulfonic acid to give two anomeric compounds $\mathbf{8 6}$ and $\mathbf{8 7}$ as an inseparable 1:1 mixture. Heterocycle-activated modified Julia olefination of $\mathbf{8 8}$ and $\mathbf{8 9}$ with aldehyde 77 affords spiroacetals 92 and 93 after hydrogenation over $\mathrm{PtO}_{2}$ [50].

NMR spectroscopy reveals that the stereochemistry at C-3 in these two compounds is opposite to that of natural products. The opposite stereochemistry at C-3 is obtained by performing Julia reaction with the known compound $\mathbf{3 3}$ to give olefins, which on subsequent reduction affords natural compounds CJ-12,954 and CJ-13,014 (Scheme 20) [32].

Scheme 20. Total synthesis of anti-Helicobacter pylori agents CJ-12,954 and CJ-13,014.

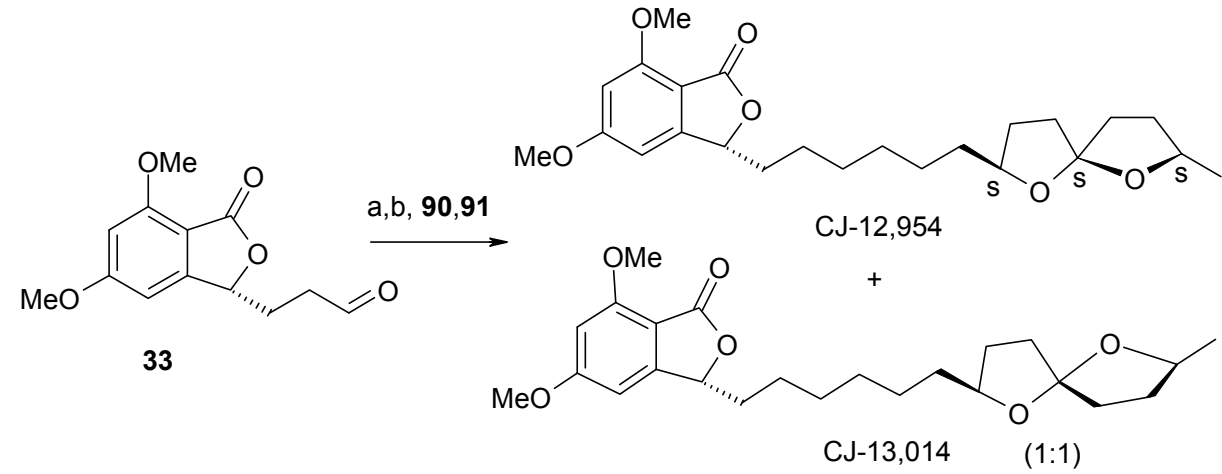

Reagents and conditions: (a) 90, 91 (1:1), KHMDS, THF, $-78{ }^{\circ} \mathrm{C}$, then 33, 76\%; (b) $\mathrm{H}_{2}, \mathrm{PtO}_{2}, \mathrm{~K}_{2} \mathrm{CO}_{3}$, THF$\mathrm{MeOH}(1: 1), 90 \%$.

\subsection{Enantioselective Synthesis of aculeatins A, B, D and 6-epi-aculeatin D}

The aculeatins A and B are two epimeric spiroacetals isolated from the terrestrial plant species Amomum aculeatum Roxb. (fam. Zingiberaceae) [51]. These compounds are found to display antiprotozoal activity against some Plasmodium and Trypanosoma species. In addition they show antibacterial activity and are cytotoxic against the KB cell line. The aculeatins A-D represent a novel type of natural compounds containing an unusual 1,7-dioxadispiro[5.1.5.2]pentadecane system.

\subsubsection{Falomir Synthesis}

Falomir and his coworkers described the enantioselective synthesis of spiroketals Aculeatin A, B, D and epi-D [51]. The retrosynthetic pathway for aculeatins A and B is shown in Scheme 21. This synthesis is based on the phenolic oxidation of an appropriately substituted ketone 94 and subsequent spirocyclisation. The ketone can be obtained from protected triol 95, which in turn is accessible from aldol condensation of 96 and $\mathbf{9 7}$, whereas 96 can be obtained by asymmetric allylation of suitably protected aldehyde $\mathbf{9 8 .}$

The synthesis starts with asymmetric allylation of 3-(p-benzyloxyphenyl)propanal 99 using the chiral allylborane prepared from allylmagnesium bromide and (-)-DIP-Cl [(-)-diisopinocamphenylchloroborane] leading to homoallyl alcohol 100 with $96 \%$ ee $[52,53]$. 
Scheme 21. Retrosynthetic analysis of aculeatins A-B.<smiles>C=C[C@H]1CC(O)CC2(CCC3(C=CC(=O)C=C3)O2)O1</smiles><smiles></smiles>

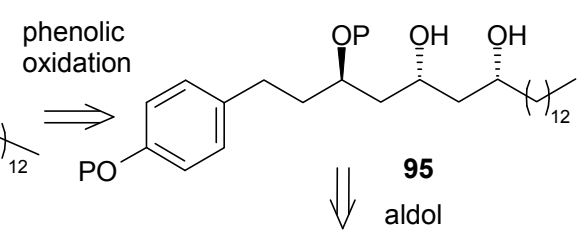

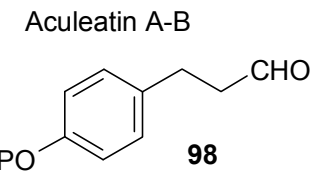<smiles>CC(=O)CC(CCc1ccc(Br)cc1)CC(C)=O</smiles>

Scheme 22. Total synthesis of aculeatins A-B.

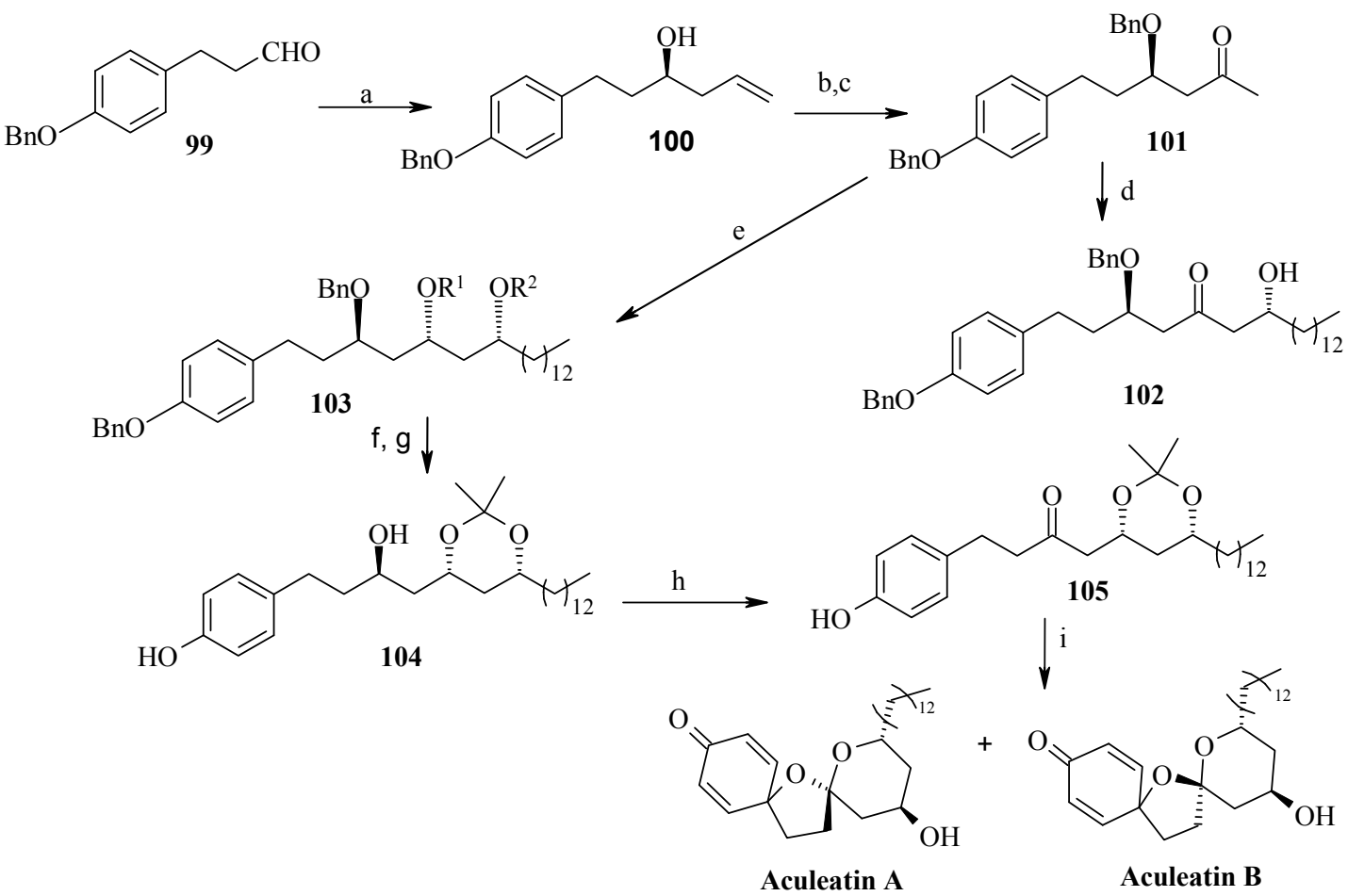

Reaction conditions: (a) allylBIpc ${ }_{2}$ from (-)- $\mathrm{Ipc}_{2} \mathrm{BCl}$ and allylmagnesium bromide, $\mathrm{Et}_{2} \mathrm{O}, 3 \mathrm{~h},-90{ }^{\circ} \mathrm{C}$; (b) $\mathrm{NaH}$, THF then $\mathrm{BnBr}$, rt, $85 \%$ overall from starting material (c) $\mathrm{PdCl}_{2}, \mathrm{CuCl}_{2}$, aq. DMF, $\mathrm{O}_{2}, 2$ days, $75 \%$; (d) $\mathrm{Bu}_{2} \mathrm{BOTf}, \mathrm{EtN} i \mathrm{Pr}_{2}, \mathrm{CH}_{2} \mathrm{Cl}_{2},-78{ }^{\circ} \mathrm{C}, 1 \mathrm{~h}$, followed by addition of $n$-tetradecanal, $3 \mathrm{~h},-78{ }^{\circ} \mathrm{C}, 70 \%$; (e) $\mathrm{Bu}_{2} \mathrm{BOTf}, \mathrm{EtNi} \mathrm{Pr}_{2}, \mathrm{CH}_{2} \mathrm{Cl}_{2},-78^{\circ} \mathrm{C}$, $1 \mathrm{~h}$, followed by addition of n-tetradecanal, $3 \mathrm{~h},-78^{\circ} \mathrm{C}$, then $\mathrm{LiBH}_{4}, 2 \mathrm{~h},-$ $78{ }^{\circ} \mathrm{C}, 65 \%$ overall; (f) 2,2-dimethoxypropane, $\mathrm{CSA}$ (cat), $\mathrm{Me}_{2} \mathrm{CO}$, rt. $1 \mathrm{~d}, 72 \%$; (g) $\mathrm{H}_{2}$, (1 atm.) $10 \% \mathrm{Pd} / \mathrm{C}$, EtOAc, rt, $6 \mathrm{~h}, 70 \%$; (h) $(\mathrm{COCl})_{2}$, DMSO, $\mathrm{CH}_{2} \mathrm{Cl}_{2},-78{ }^{\circ} \mathrm{C}$, then $\mathrm{Et}_{3} \mathrm{~N},-78{ }^{\circ} \mathrm{C}$ to $0{ }^{\circ} \mathrm{C}, 87 \%$; (i) $\mathrm{PhI}\left(\mathrm{OOCCF}_{3}\right)_{2}$, $\mathrm{Me}_{2} \mathrm{CO}-\mathrm{H}_{2} \mathrm{O}(9: 1)$, rt, 24h, 65\% overall, 5.5:1 mixture of aculeatins A and $\mathrm{B}$. 
Benzylation and Wacker oxidation followed by boron aldol reaction of allyl alcohol $\mathbf{1 0 0}$ provides the desired aldol 102 as a single disastereomer [54-56]. The aldol is then reduced in situ to the monobenzylated anti, syn-1,3,5-triol 103 with $\mathrm{LiBH}_{4}$. Protection of the two free hydroxyl groups as an acetonide, followed by hydrogenolytic debenzylation affords 104, which on Swern oxidation furnishes ketone 105. The ketone $\mathbf{1 0 5}$ is then subjected to hydrolytic cleavage of the acetonide moiety but the yield of expected $\beta, \delta$-dihydroxy ketone is low $(<35 \%)$. The treatment of acetonide 104 with phenyliodonium bis(trifluoroacetate) not only causes the desired phenolic oxidation, but also acetonide hydrolysis and subsequent spiroacetalization (Scheme 22) [57,58]. This cleanly gives a 5.5:1 mixture of two optically active products with spectral properties identical to those reported for aculeatins A and $\mathrm{B}$.

Scheme 23. Total synthesis of (+)-aculeatin D and (+)-6-epi-aculeatin D.

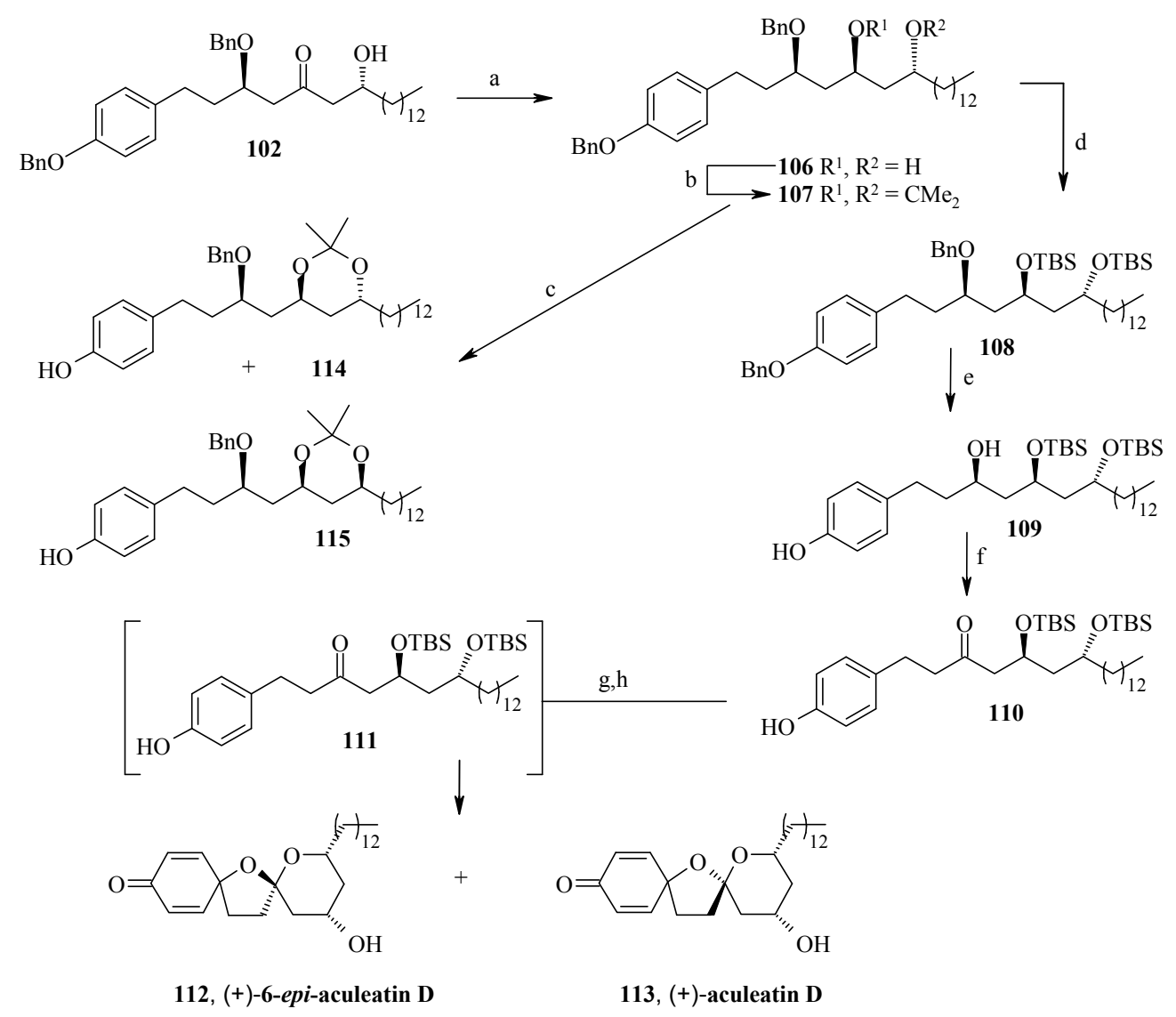

Reaction conditions: (a) TABH, AcOH-MeCN, $-30{ }^{\circ} \mathrm{C}, 12 \mathrm{~h}, 86 \%$; (b) 2,2-dimethoxypropane, CSA (cat), $\mathrm{Me}_{2} \mathrm{CO}$, rt, 12h, 89\%; (c) $\mathrm{H}_{2}$, (1 atm), 10\% Pd/C, EtOAc, rt, 6h, 40\%; (d) TBSOTf, 2,6-lutidine, $\mathrm{CH}_{2} \mathrm{Cl}_{2}$, heat, 91\%; (e) $\mathrm{H}_{2}$, (1 atm), 10\% Pd/C, EtOAc, rt, $15 \mathrm{~min}, 74 \%$; (f) $(\mathrm{COCl})_{2}, \mathrm{DMSO}, \mathrm{CH}_{2} \mathrm{Cl}_{2},-78{ }^{\circ} \mathrm{C}$, then $\mathrm{Et}_{3} \mathrm{~N},-78{ }^{\circ} \mathrm{C}$ to $0{ }^{\circ} \mathrm{C}, 81 \%$; (g) TASF, DMF, $0{ }^{\circ} \mathrm{C}, 90 \mathrm{~min}$, then rt, $4 \mathrm{~h}$; (h) $\mathrm{PHI}\left(\mathrm{OOCCF}_{3}\right)_{2}, \mathrm{Me}_{2} \mathrm{CO}-\mathrm{H}_{2} \mathrm{O}$ (9:1), rt, 30 min, 77\% over two steps, 2.7:1 mixture of aculeatin D (minor) and 6-epi-aculeatin D (major).

The synthesis of aculeatin D and 6-epi-aculeatin D is achieved by inversion of configuration at C-4. Thus, aldol 102 is stereoselectively reduced with TABH to afford the expected anti-1,3-diol 106 [59]. In this case the free hydroxyl groups of $\mathbf{1 0 6}$ are not protected as an acetonide because it gives 
unwanted rearranged acetonide $\mathbf{1 1 5}$ as major product under the hydrolytic conditions (Scheme 23). This problem can be solved by double silylation of diol 106 with TBSOTf, and subsequent hydrogenolysis to give compound 109. Swern oxidation and desilylation of $\mathbf{1 0 9}$ under mild conditions with TASF affords the diol 111 [60], which is subjected to oxidative spiroacetalization with $\mathrm{PhI}\left(\mathrm{OCOCF}_{3}\right)_{2}$ to yield a 2.7:1 mixture of compounds 113 (minor) and $\mathbf{1 1 2}$ (major), without any 4hydroxycyclohexa-2,5-dienone formation. Compounds 113 and 112 displays physical and spectral features identical to those reported for natural aculeatin D and 6-epi-aculeatin D.

\subsubsection{Chandrasekhar Synthesis of aculeatins $A$ and $B$}

Chandrasekhar et al. have synthesized aculeatin A and B via a tethered oxa-Michael approach [61]. The retrosynthetic pathway is shown in Scheme 24, where 4-benzyloxyphenyl acetylene 118 and tetradecanal (119) are the starting materials. The allylic alcohol $\mathbf{1 2 0}$ is synthesized from aldehyde $\mathbf{1 1 9}$ using a Maruoka allylation [62]. This compound is then converted to unsaturated ester 121 by ozonolysis and subsequent two-carbon homologation and is used for the tethered intramolecular oxaMichael reaction to install the second stereocenter. Thus, reaction of $\mathbf{1 2 1}$ with benzaldehyde and potassium tert-butoxide affords benzylidene acetal 122 with 95\% diastereoselectivity favouring the more stable syn-isomer [63]. Acetal 122 is then converted to Weinreb amide 117, which upon treatment with lithiated 4-benzyloxyphenylacetylene 118 affords fragment alkynone $\mathbf{1 1 6 .}$

Scheme 24. Retrosynthetic analysis of aculeatins A-B.

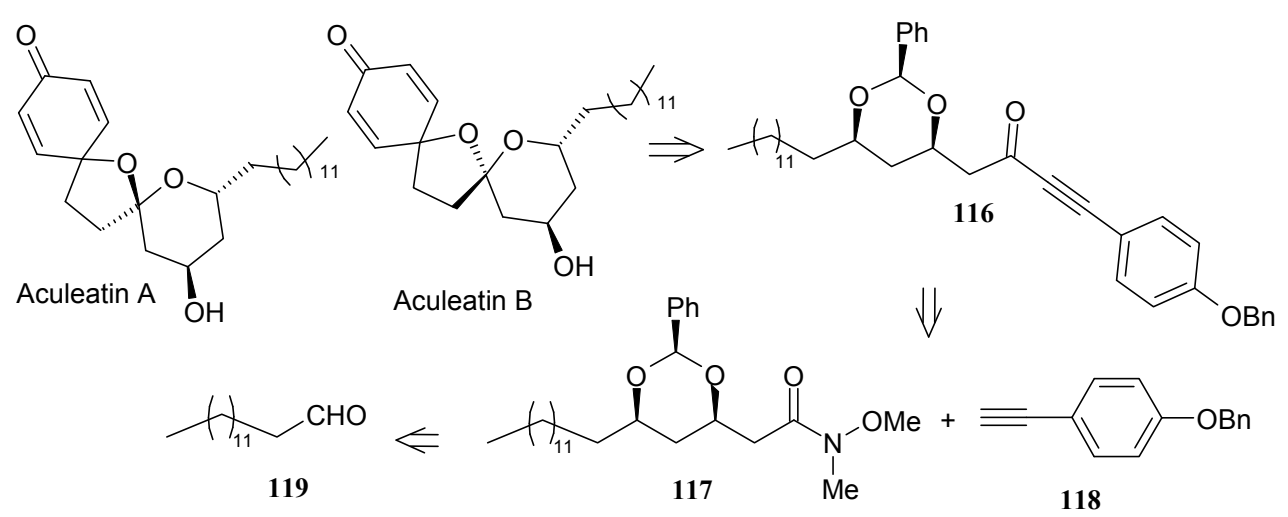

Catalytic hydrogenation of 116 gives intermediate 124, which on treatment with phenyliodonium (III) bis(trifluoroacetate) (PIFA) affords aculeatins A and B as a 5:2 mixture, which can be separated by column chromatography (Scheme 25) [64]. 
Scheme 25. Total synthesis of (+)-aculeatin D and (+)-6-epi-aculeatin D.

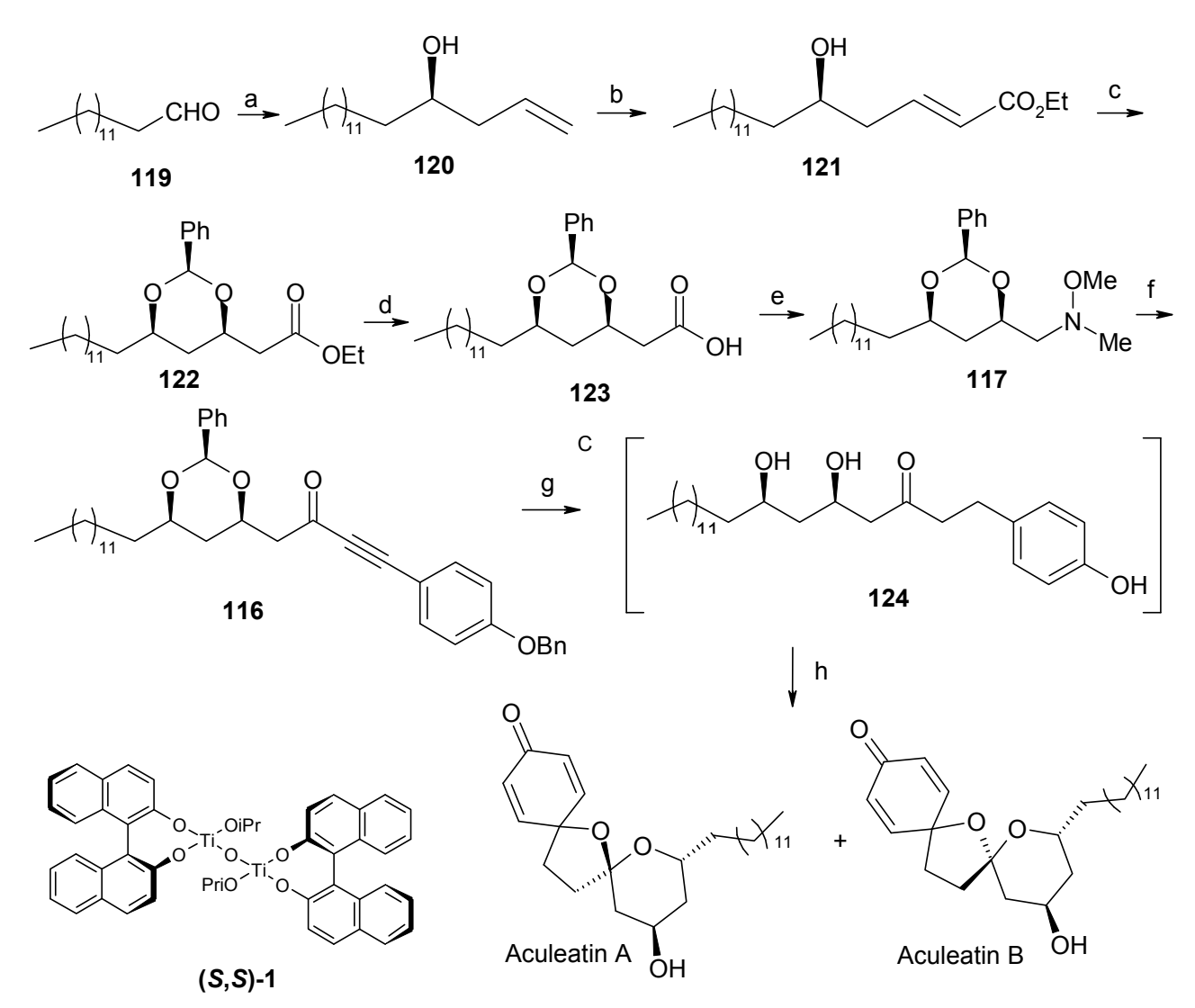

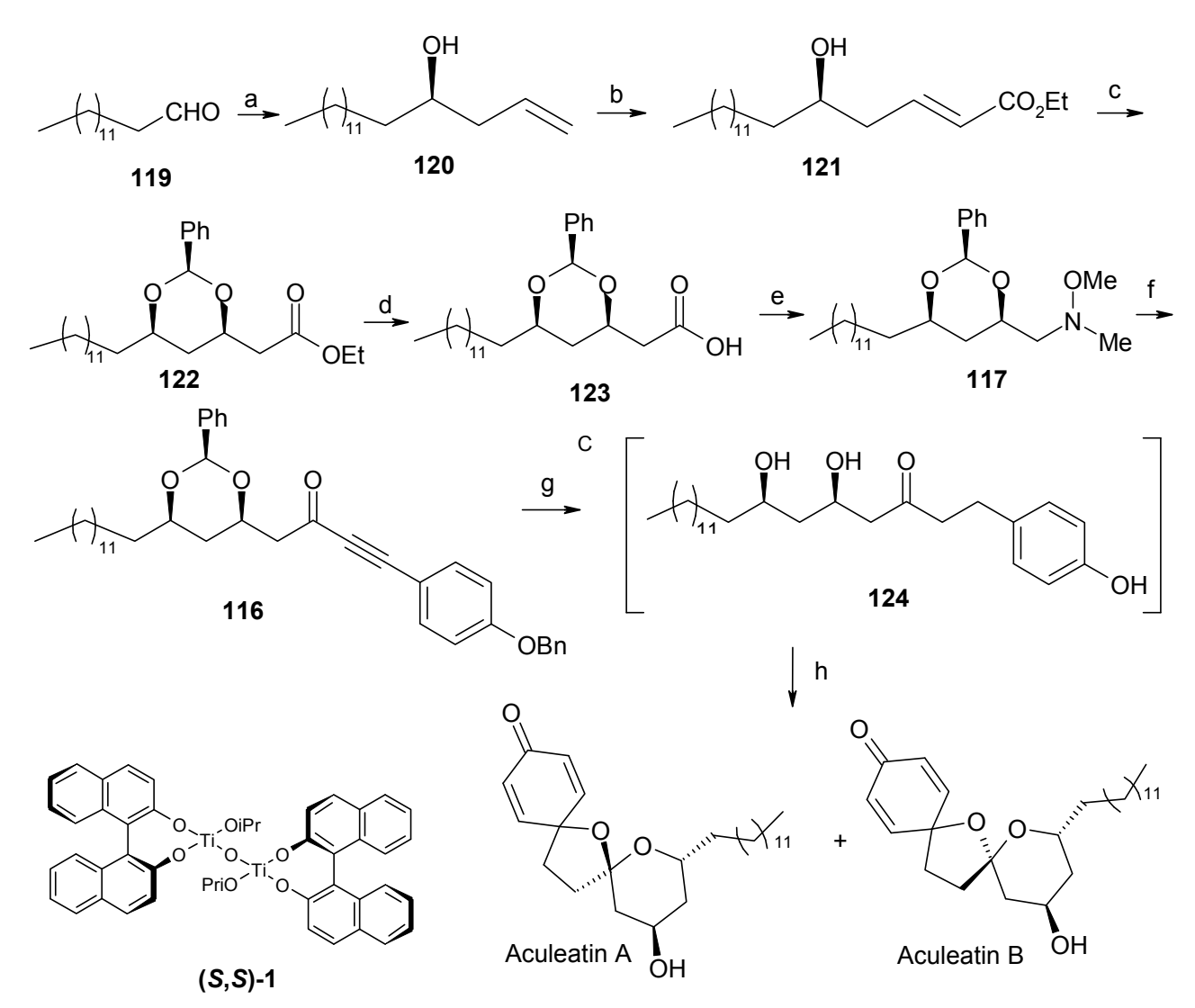

$(S, S)-1$

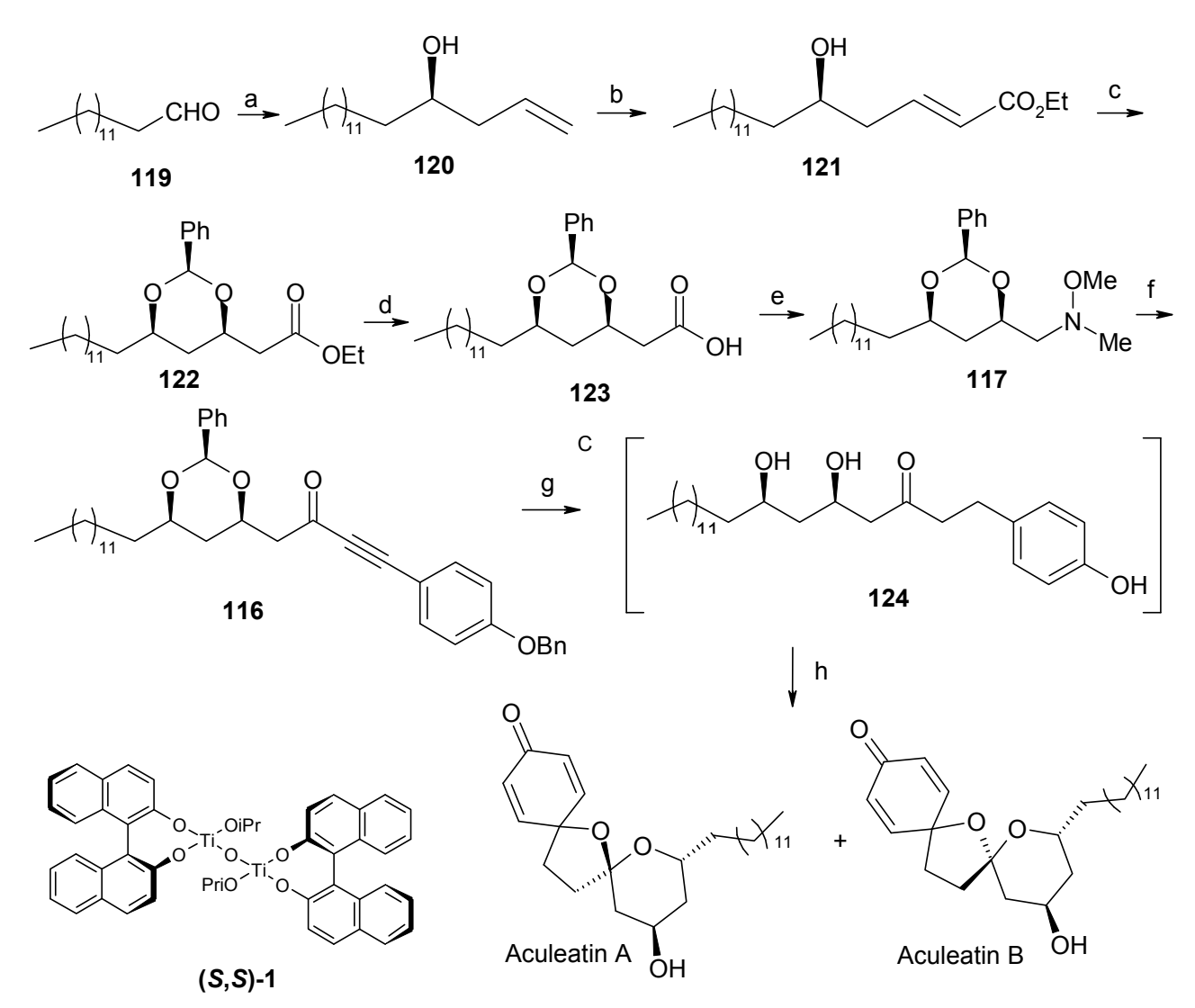
117

Reagents and conditions: (a) (S,S)-1 (10 mol \%), $\mathrm{Bu}_{3} \mathrm{SnCH}_{2} \mathrm{CH}=\mathrm{CH}_{2}, \mathrm{CH}_{2} \mathrm{Cl}_{2},-15{ }^{\circ} \mathrm{C}$ to $0{ }^{\circ} \mathrm{C}, 24 \mathrm{~h}, 86 \%$, (b) (i) $\mathrm{O}_{3}, \mathrm{CH}_{2} \mathrm{Cl}_{2},-78{ }^{\circ} \mathrm{C}, 45 \mathrm{~min}$, then $\mathrm{Ph}_{3} \mathrm{P}$, (ii) $\mathrm{Ph}_{3} \mathrm{P}=\mathrm{CHCO}_{2} \mathrm{Et}, \mathrm{CH}_{2} \mathrm{Cl}_{2}, \mathrm{rt}, 2 \mathrm{~h}, 80 \%$ (for two steps), (c) PhCHO, $t$-BuOK, THF, $0{ }^{\circ} \mathrm{C}, 45 \mathrm{~min}, 69 \%$, (d) $\mathrm{LiOH}$, THF- $\mathrm{H}_{2} \mathrm{O}(3: 1), 0{ }^{\circ} \mathrm{C}$, to rt, $4 \mathrm{~h}, 91 \%$, (e) $\mathrm{NH}(\mathrm{Me})(\mathrm{OMe}) \cdot \mathrm{HCl}, \mathrm{DCC}, \mathrm{Et}_{3} \mathrm{~N}$, DMAP, $\mathrm{CH}_{2} \mathrm{Cl}_{2}, 0{ }^{\circ} \mathrm{C}$ to rt, $90 \%$, (f) $n$-BuLi, 118, THF, $-78{ }^{\circ} \mathrm{C}$ to $-22{ }^{\circ} \mathrm{C}$, 75\%, (g) $\mathrm{Pd} / \mathrm{C}, \mathrm{H}_{2}$, EtOAc, rt, (h) $\mathrm{PhI}\left(\mathrm{OOCCF}_{3}\right)_{2}, \mathrm{Me}_{2} \mathrm{CO}-\mathrm{H}_{2} \mathrm{O}$ (9:1), rt, 10 min, 52\% (two steps), 2.5:1 mixture of aculeatins A and B.

\subsubsection{Wong Synthesis}

Wong and co-workers have synthesized aculeatins A, B, D and 6-epi-aculeatin D using a Mukaiyama aldol condensation as a key reaction [65]. The retrosynthesis reveals that the required fragments 125 and 126 can be obtained from homochiral $\beta$-alkoxy aldehyde 127 and enolsilane 128 in a diastereodivergent process (Scheme 26).

Several hydroxy-protected aldehydes $\mathbf{1 2 7}$ were prepared starting from alcohol 129 using Nokami's enantioselective crotylation, protection and oxidation sequence (Scheme 27) [66,67]. On the other hand the enolsilane 128 is synthesized from ketone 133. It was observed that the aldol reaction of 128 and aldehyde 127 having a PMB protecting group proceeded with a good 1,3-anti induction ( $\mathrm{dr}=$ 92:08) to give anti product, whereas with bulky silyl ether dramatically reduce the 1,3-anti induction. For TBS ether the anti/syn ratio is 60:40 and for TPS and TIPS there is no 1,3-induction. 
Scheme 26. Retrosynthetic analysis of aculeatins A, B, D and 6-epi-aculeatin D.

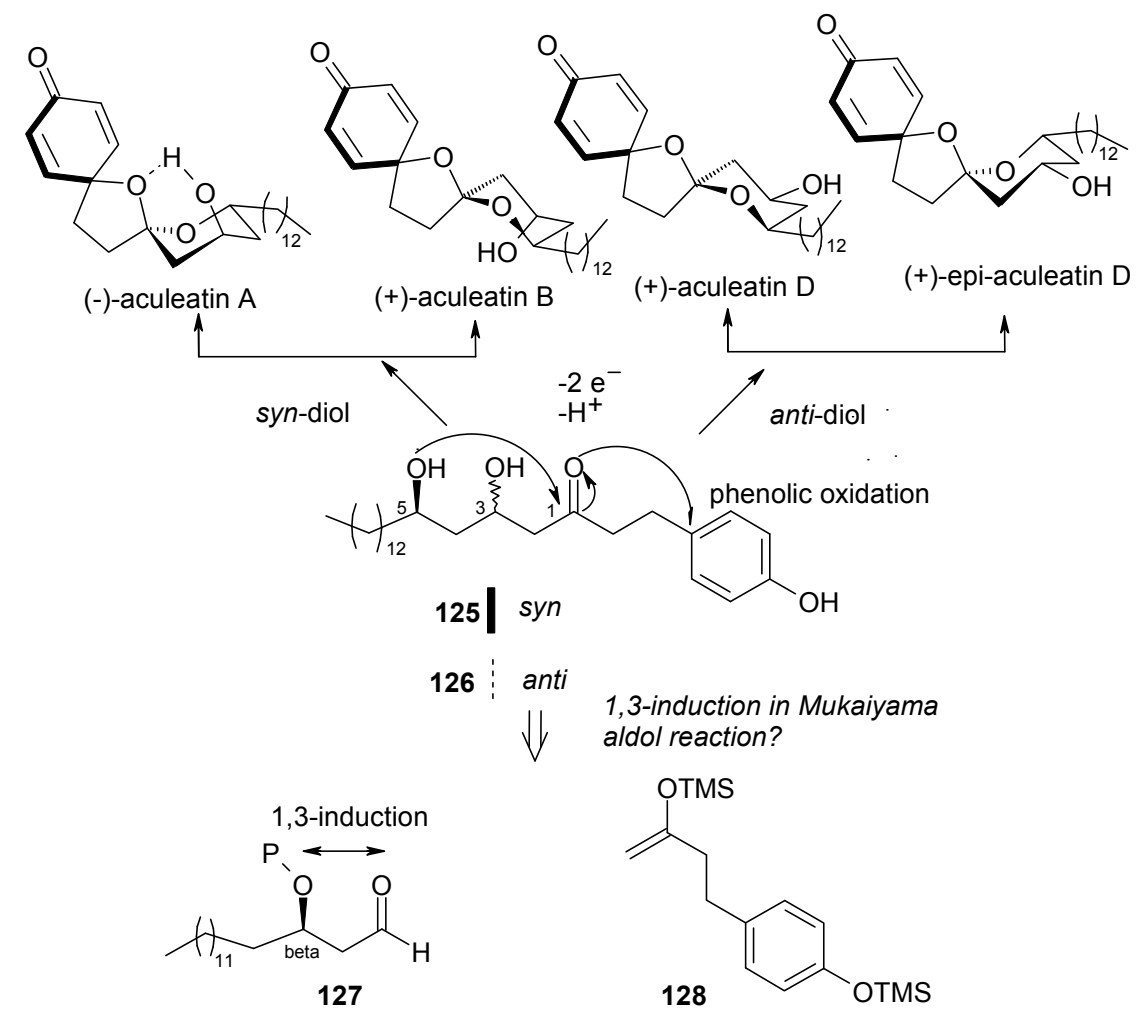

Scheme 27. Synthesis of fragment 128.

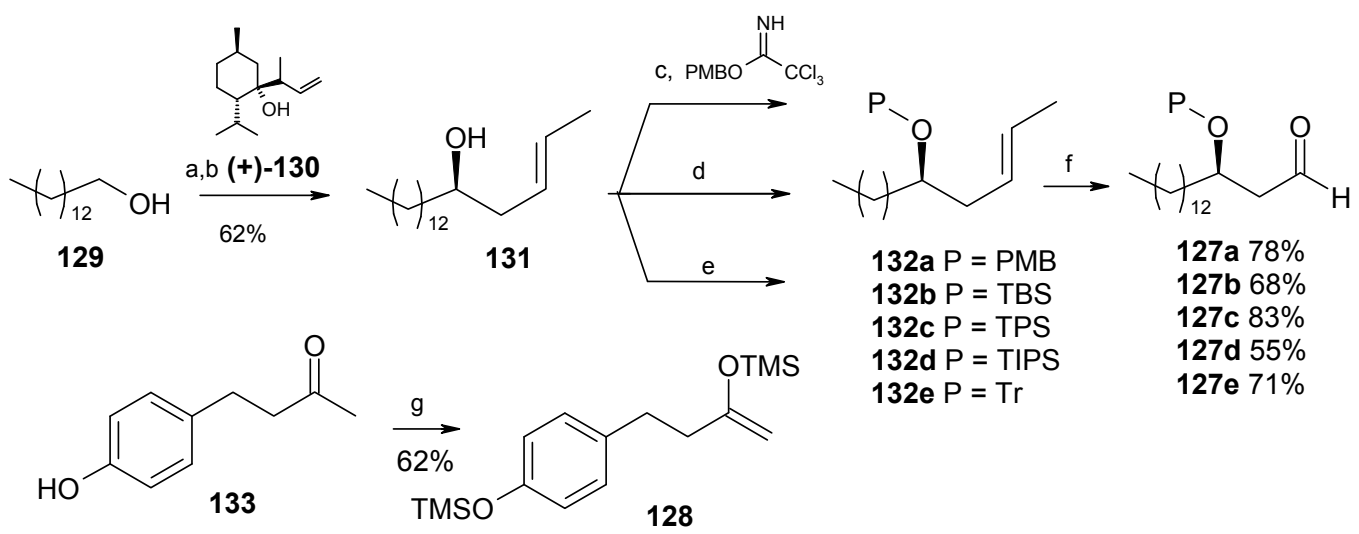

Reagents and conditions: (a) PCC; (b) (+)-130, p-TsOH, $\mathrm{CH}_{2} \mathrm{Cl}_{2}, 62 \%$; (c) $\mathrm{CSA}, \mathrm{CH}_{2} \mathrm{Cl}_{2}$; (d) $\mathrm{R}_{3} \mathrm{SiCl}$, imidazole; (e) $\mathrm{TrCl}, \mathrm{Et}_{3} \mathrm{~N}, \mathrm{CH}_{2} \mathrm{Cl}_{2}$; (f) $\mathrm{NMO}, \mathrm{OsO}_{4}, \mathrm{NaIO}_{4}$; (g) LDA, THF, $-78{ }^{\circ} \mathrm{C}, \mathrm{TMSCl}, 62 \%$.

During aldol reaction two compounds 125 and $(+)-134$ are isolated. Here the aldol product 125 does not cyclise due to the strong hydrogen bonding whereas product $(+)-\mathbf{1 3 4}$ is formed from the cyclisation of anti isomer 126, which lack of hydrogen bonding (Scheme 28). Next the compounds 125 and 134 are converted to methoxy-protected ketals 135 and 136 (Scheme 29). Finally the compounds 125, 134, 135 and 136 are subjected to spirocyclisation in different conditions to give aculeatins A, B, D and 6epi-aculeatin D. For all spirocyclisation water is an important medium. Thus, oxidation of 3,5-syn-diol 
ketone 125 with PIFA generates the reactive phenoxonium cation 137, which is responsible for further spirocyclisation via oxocarbonium ion 138 to give (-)aculeatin A and B with 48\% and 34\% respectively (Scheme 30).

Scheme 28. Synthesis of fragments $\mathbf{1 2 5}$ and $\mathbf{1 2 6}$.
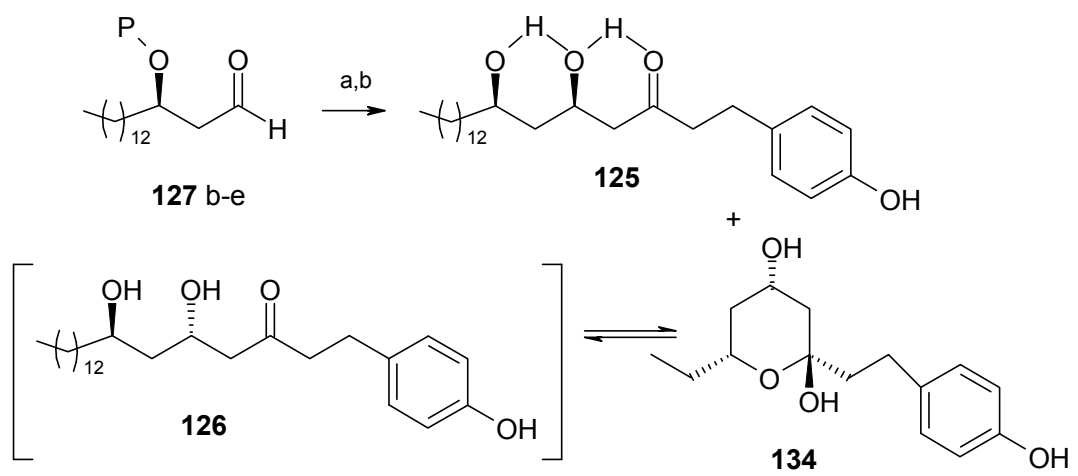

Reagents and conditions: (a) 128, $\mathrm{BF}_{3} \cdot \mathrm{Et}_{2} \mathrm{O},-78^{\circ} \mathrm{C}, \mathrm{CH}_{2} \mathrm{Cl}_{2}$; (b) $\mathrm{Bu}_{4} \mathrm{NF}$, THF.

Scheme 29. Synthesis of methoxy-protected ketals 135 and 136.<smiles>CCC1CC(CCCc2ccc(O)cc2)OCO1</smiles><smiles>CC[C@H]1CC(O)C[C@@](Cc2ccc(O)cc2)(OC(C)C)O1</smiles><smiles>CC[C@H]1CC(O)CC(O)(Cc2ccc(O)cc2)O1</smiles><smiles>CC[C@H]1C[C@@H](O)C[C@@](C)(Cc2ccc(O)cc2)O1</smiles>

Reagents and conditions: (a) $\mathrm{MeOH}$, reflux, 16h; (b) $\mathrm{MeOH}$, reflux, 5h

Scheme 30. Total synthesis of aculeatin A-B.

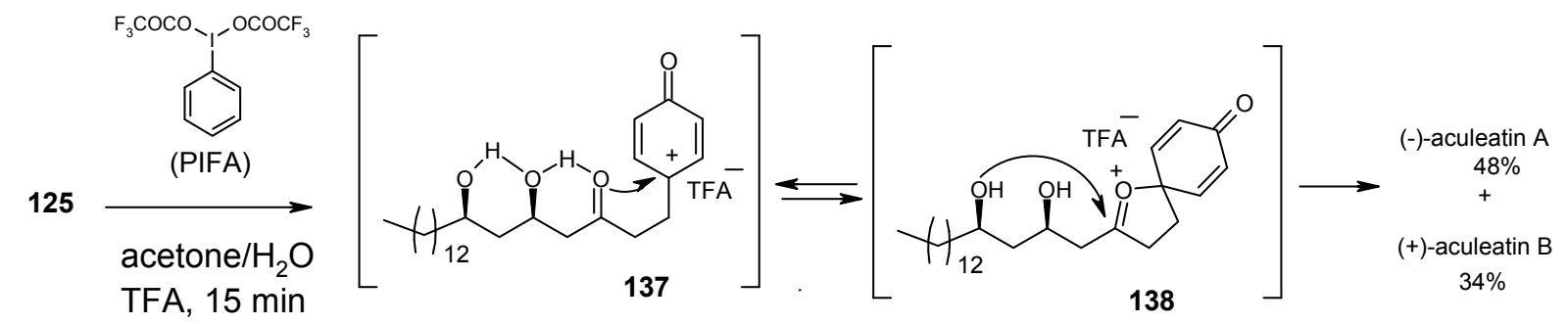


On the other hand the ketals 134-136 when treated with PIFA afforded aculeatin A and 6-epiaculeatin D and aculeatin B and D via pathways 1-2 (Scheme 31). The phenoxonium cation 139 can be trapped by an intramolecular OR group 139a $(\mathrm{R}=\mathrm{H}$, path 1$)$, rather than a less nucleophilic oxygen atom from the methoxy group in $139 \mathrm{~b}(\mathrm{R}=\mathrm{Me}$, path 2$)$, forming aculeatin A or 6-epi-aculeatin $\mathrm{D}$. The quenching the phenoxonium cation by water leads to intermediates $p$-quinols 140a and 140b which after $\mathrm{S}_{\mathrm{N}} 2$ reaction gives aculeatin $\mathrm{B}$ and $\mathrm{D}$ (Scheme 31$)$.

Scheme 31. Total synthesis of aculeatin A, B, D and 6-epi-aculeatin D.
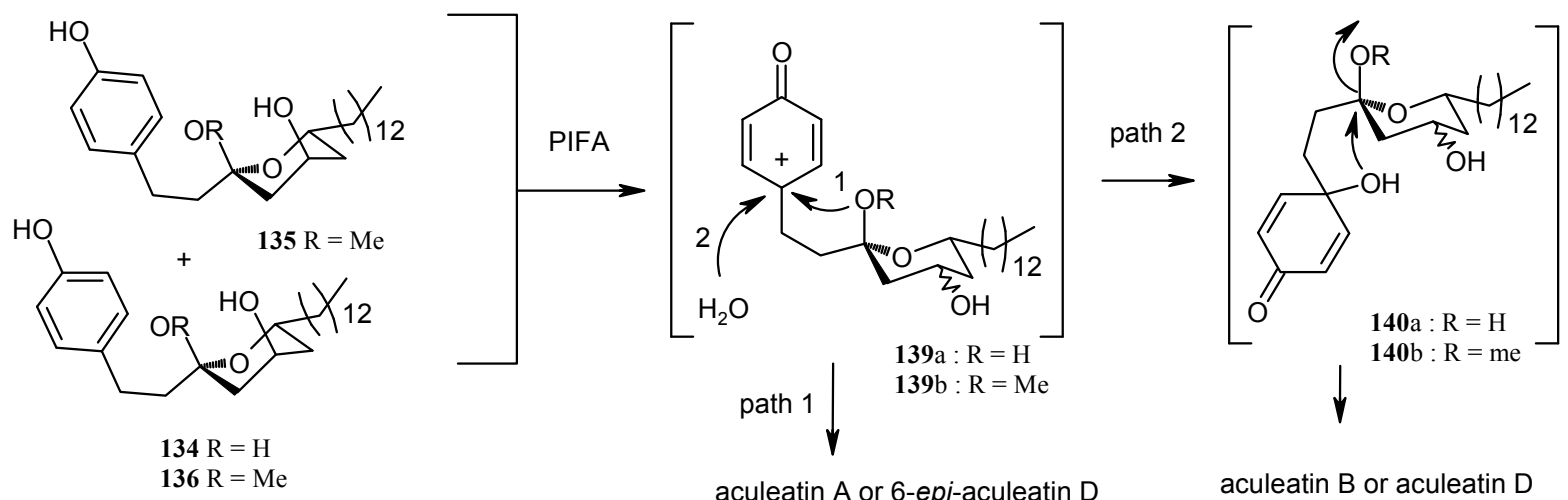

In summary all three methods utilize the same phenolic oxidation strategy for the construction of spiroketal moiety of aculeatins A, B and D. The Falomir and Wong groups applied the asymmetric aldol reaction to introduce the stereocenters whereas Chandrasekhar's group adopted the tethered oxaMichael approach. All the three approaches are short and completed within 6-8 steps.

\subsection{Enantioselective Total synthesis of (+)-Aigialospirol}

Isaka reported the isolation of (+)-aigialospirol, which was obtained after an extended fermentation of the marine fungus Aigialus parvus BCC 5311 that was found in the mangrove Ascomycete [68]. $(+)$-Aigialospirol possesses potent antimalarial and anticancer properties $[69,70]$.

Scheme 32. Retrosynthetic analysis of (+)-aigialospirol.
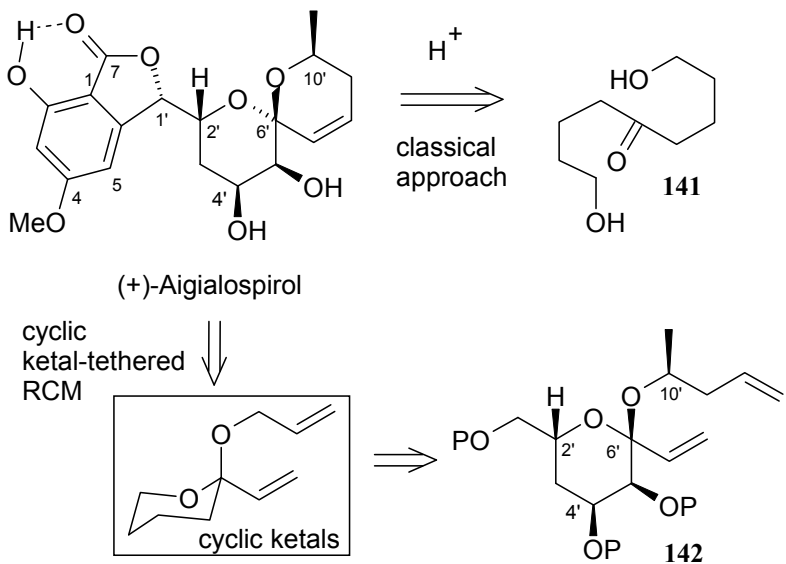
Hsung and coworkers have reported the synthesis of (+)-aigialospirol by using a cyclic ketaltethered ring-closing metathesis (RCM) strategy [71]. The retrosynthetic analysis is shown in Scheme 32. It reveals that the synthesis of unit $\mathbf{1 4 2}$ is the key step in the total synthesis.

Scheme 33. Synthesis of key cyclic ketal 148.
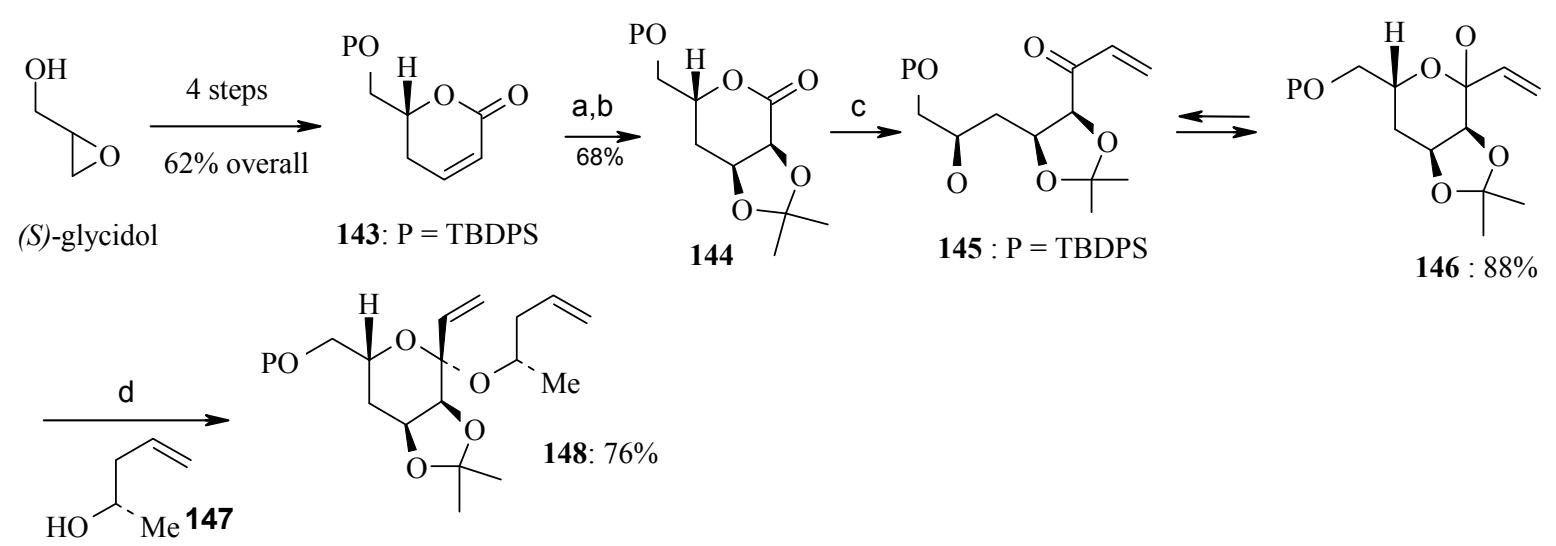

Reagents and conditions: (a) $6.0 \mathrm{~mol} \% \mathrm{OsO}_{4}, \mathrm{NMO}, \mathrm{Me}_{2} \mathrm{CO} / \mathrm{H}_{2} \mathrm{O}$, rt; (b) $p$ - $\mathrm{TsOH},\left(\mathrm{CH}_{3}\right)_{2} \mathrm{C}(\mathrm{OMe})_{2} ; \mathrm{Me}_{2} \mathrm{CO}$, rt, $68 \%$; (c) $\mathrm{CH}_{2}=\mathrm{CHMgBr}, \mathrm{Et}_{2} \mathrm{O},-78^{\circ} \mathrm{C}$; (d) $147, \mathrm{Tf}_{2} \mathrm{NH}, 4 \mathrm{~A}^{\circ}, \mathrm{CH}_{2} \mathrm{Cl}_{2},-78^{\circ} \mathrm{C}$.

The unit dihydro- $\alpha$-pyrone 143 for the synthesis of key unit 142 is prepared from $(S)$-glycidol, which provides the required stereochemistry at C-2' in 62\% yield over four steps (Scheme 33) [72]. The compound 143 on dihydroxylation followed by acetonide formation gives $\delta$-lactone 144, which on treatment with vinyl Grignard gives an equilibrating mixture of vinyl ketone 145 and lactol 146 [73]. The key intermediate $\mathbf{1 4 8}$ is achieved from the lactol-ketone mixture and the chiral homoallylic alcohol 147 by treatment with $\mathrm{TF}_{2} \mathrm{NH}$ (Scheme 33) [74, 75].

The cyclic ketal 148 is subjected to ring-closing metathesis employing Grubb's first generation catalyst to give 149 [76]. The acetonide group is removed under acidic conditions which also completely epimerize the spiroketal center to the desired C-6' stereocenter, as confirmed by NOE and $\mathrm{X}$-ray structure of diol 150 (Scheme 34).

Scheme 34. Cyclic ketal-tethered RCM and C-6' epimerization.<smiles>[M]C(CC=C)O[C@]1(C=C)O[C@H](C[18OH])C[C@@H]2OC(C)(C)O[C@H]21</smiles>

148

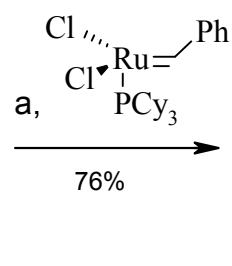<smiles>[M]C1CC=CC2(O1)OC(C)(C)C[C@H]1OC(C)(C)O[C@H]12</smiles>

$149: 86 \%$

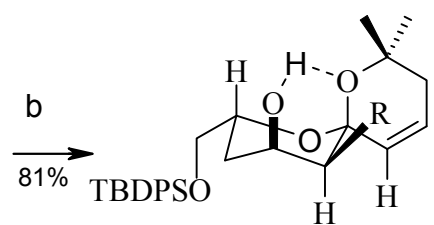

$150: \mathrm{R}=\mathrm{OH}$

Reagents and conditions: (a) Grubbs' Gen-1, toluene; (b) p-TsOH, $\mathrm{MeOH}$, rt. 
Scheme 35. Total synthesis of (+)-aigialospirol.

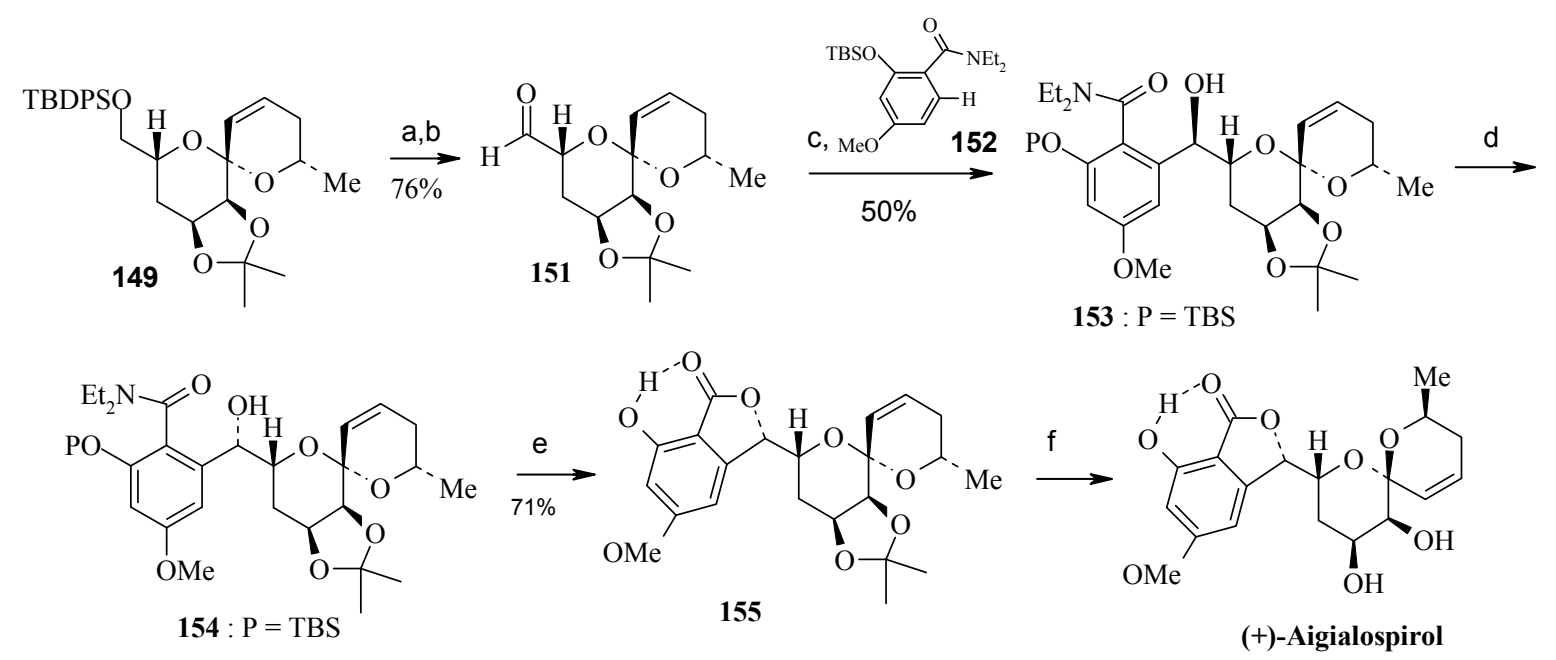

Reagents and conditions: (a) TBAF, THF, rt; (b) TEMPO, BAIB, $\mathrm{CH}_{2} \mathrm{Cl}_{2}, \mathrm{rt}, 76 \%$; (c) $s$-BuLi, TMEDA, THF, $-78{ }^{\circ} \mathrm{C}, 50 \%$; (d) w/silica gel; (e) $\mathrm{KOH}, \mathrm{MeOH} / \mathrm{H}_{2} \mathrm{O} / \mathrm{THF}$, rt; (f) $p$-TsOH, MeOH, rt, 53\%.

Desilylation and oxidation of 149 gives aldehyde 151 and subsequent addition of the aryl lithium intermediate, generated via a Snieckus' directed ortho-metallation of amide $\mathbf{1 5 2}$ affords a readily separable mixture of alcohols 153 and 154 with an isomeric ratio 1:1.4 [77, 78]. Both 153 and 154 lead to the same lactone 155 (with loss of the TBS group) (Scheme 35). Lactone 155 is hydrolyzed to give (+)-aigialospirol concomitant with C-6' epimerization.

2.7. Enantioselective Synthesis of 2,7-Dimethyl-1,6-dioxaspiro[4.6] undecane and 2,7-diethyl-1,6dioxaspiro[4.6] undecane using functionalized nitroalkane synthons

The vast majority of spiroketal pheromones fall either into spiro[5.5]- or spiro[4.4]- or spiro [4.6] groups of which the spiro [4.6] group are relatively rare.

Scheme 36. Total synthesis of 2,7-dimethyl-1,6-dioxaspiro[4.6]undecane and 2,7-diethyl1,6-dioxaspiro[4.6] undecane.
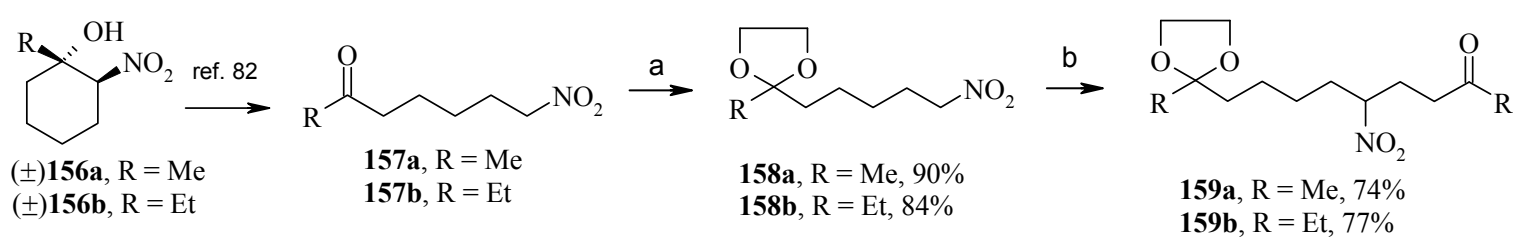<smiles>[R]C(=O)CCCCC(CCC([R])C)[N+](=O)[O-]</smiles>

( \pm ) $160 \mathrm{a}, \mathrm{R}=\mathrm{Me}, 95 \%$

( \pm ) $160 \mathrm{~b}, \mathrm{R}=\mathrm{Et}, 92.5 \%$<smiles>[R]C(O)CCCCC(CCC([R])O)[N+](=O)[O-]</smiles>

$(2 S, 10 S)-161 \mathrm{a}, \mathrm{R}=\mathrm{Me}, 55 \%$ $(3 S, 11 S)-161 b, R=E t, 67 \%$

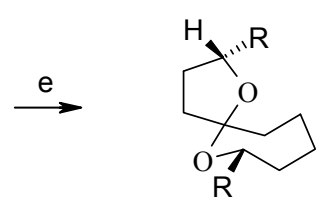

$(2 S, 5 R, 7 S)-162 a, \mathrm{R}=\mathrm{Me}, 75 \%$ $(2 S, 5 R, 7 S)-\mathbf{1 6 2} \mathbf{b}, \mathrm{R}=\mathrm{Et}, 72 \%$

Reagents and conditions: (a) $\mathrm{HO}\left(\mathrm{CH}_{2}\right)_{2} \mathrm{OH}$, benzene, $80{ }^{\circ} \mathrm{C}$; (b) MVK, amberlyst-A21; (c) $2 \mathrm{~N} \mathrm{HCl}, \mathrm{Me}_{2} \mathrm{CO}$; (d) Baker's yeast, glucose, $\mathrm{H}_{2} \mathrm{O}$, rt; (e) $\mathrm{NaOH}, 10 \% \mathrm{H}_{2} \mathrm{SO}_{4}$. 
Saikia et al. [79] developed a short enantioselective synthesis of both 2,7-dimethyl-1,6dioxaspiro[4.6] undecane $[(2 S, 5 R, 7 S)$-162a $]$ and 2,7-diethyl-1,6-dioxaspiro[4.6]undecane [(2S,5R,7S)-162b], the pheromones produced by Andrena Haemorrhoa [80] (2 isomers) and Andrena wilkella [81] (2 isomers), respectively. 7-Nitroheptan-2-one (157a) and 8-nitrooctan-3-one (157b) are prepared by refluxing $(+)-156 a$ and $(+)-\mathbf{1 5 6 b}$, respectively, in anhydrous benzene with anhydrous

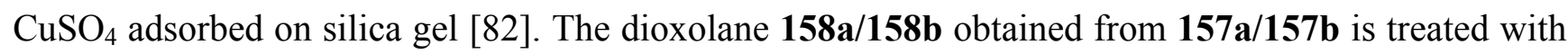
methyl vinyl ketone (MVK) and amberlyst A-21 resin at room temperature and in absence of solvent giving the Michael adduct $(+)-\mathbf{1 5 9} \mathbf{a} / \mathbf{1 5 9}$, which on heating with $5 \% \mathrm{HCl}$ gives the unsymmetrical 1,9-diketone $(+)-\mathbf{1 6 0 a} / \mathbf{1 6 0 b}$ in $95 \% / 92.5 \%$ yield as a gum. Bioreduction of $(+)-\mathbf{1 6 0 a} / \mathbf{1 6 0 b}$ with baker yeast affords the diol $(2 S, 10 S)-\mathbf{1 6 1 a} / \mathbf{1 6 1 b}$ in 55\%/67\% yield (Scheme 36). The $(S, S)$ stereochemistry has been assigned to the newly generated alcohol functionality at C-2 and C-10 in 161a/161b based on the observations made by Occhiato et al. that baker's yeast reduction of symmetrical diketones having two carbonyl groups in 1,4- or more distant positions occurs independently on the two oxo groups and in such compounds the bioreduction affords $(S, S)$ diols according to Prelog's rule [83]. In this case also the unsymmetrical diketone $\mathbf{1 6 0 a} / \mathbf{1 6 0 b}$ after bioreduction gives $(S, S)$-diols $(2 S, 10 S)$-161a. Treatment of 161a and 161b with $\mathrm{NaOH}$ in ethanol and then with the two-layer system, dilute $\mathrm{H}_{2} \mathrm{SO}_{4} /$ hexane affords $(2 S, 5 R, 7 S)$-162a and $\mathbf{1 6 2} \mathbf{b}$ respectively.

\subsection{A ketal-tethered RCM strategy towards the synthesis of spiroketal related natural products Synthesis of a simple insect pheromone}

Hsung and co-workers have used ketal-tethered ring closing metathesis (RCM) for a short total synthesis of an adrena bee pheromone (Scheme 37) [84, 85, 86]. The synthesis starts with the dihydropyranpyran 164. Addition of its 2-lithiated intermediate to crotyl bromide followed by the ketal formation using allyl alcohol and PPTS affords ketal 166 in 30\% overall yield with modest diastereoselectvity (dr 4:1) [87].

Scheme 37. Ketal tethered RCM: Synthesis of spiroketal.

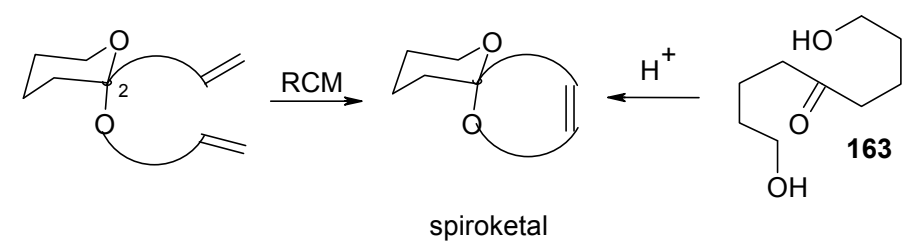

Application of RCM to ketal 166 using the Grubb's generation-I Ru-catalyst $\mathbf{1 6 7}$ leads to the formation of spiroketal 168, which on subsequent hydrogenation provides the bee pheromone 169 (Scheme 38) [88,89]. 
Scheme 38. Total synthesis of insect pheromone 169.

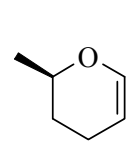

164

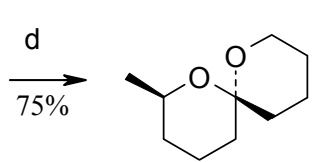

169
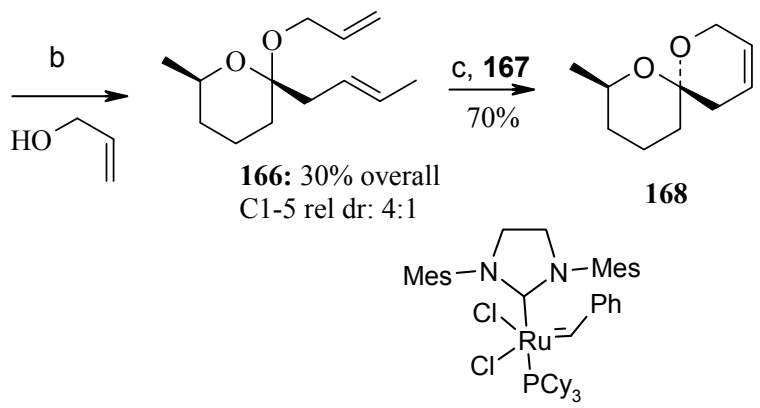

167

Reagents and conditions: (a) t-BuLi, THF, $-78{ }^{\circ} \mathrm{C}$, rt; (b) PPTS, $\mathrm{CH}_{2} \mathrm{Cl}_{2}$; (c) Grubbs Gen-1, 167, 73\%; (d) $\mathrm{H}_{2}, \mathrm{Pd} / \mathrm{C}, \mathrm{EtOAc}, 75 \%$.

\subsection{Total Synthesis of Reveromycin- $A$}

Reveromycin A is a member of a family of compounds isolated from the soil actinomycete Steptomyces sp [90]. Reveromycin A is a potent inhibitor (IC50 $0.7 \mu \mathrm{g} \mathrm{mL}^{-1}$ ) of the mitogenic activity of epidermal growth factor (EGF) in a mouse keratinocyte. In addition, reveromycin A exhibits antifungal activity (MIC) $2.0 \mu \mathrm{g} \mathrm{mL}-1, \mathrm{pH} 3$ ) [90]. Recently, reveromycin A has been identified as a specific inhibitor of Saccharomyces cerevisiae isoleucyl-tRNA synthetase (IleRS) using yeast genetics and biochemical studies [91].

\subsubsection{Rizzacasa Synthesis}

Rizzacasa and his coworkers reported a total synthesis of (-)-reveromycin A using a Lewis acid catalyzed inverse electron demand hetero-Diels-Alder (HDA) strategy to construct the challenging spiroketal moiety of this molecule [92]. The retrosynthetic disconnection is shown in Scheme 39.

Scheme 39. Retrosynthetic analysis of reveromycin A.

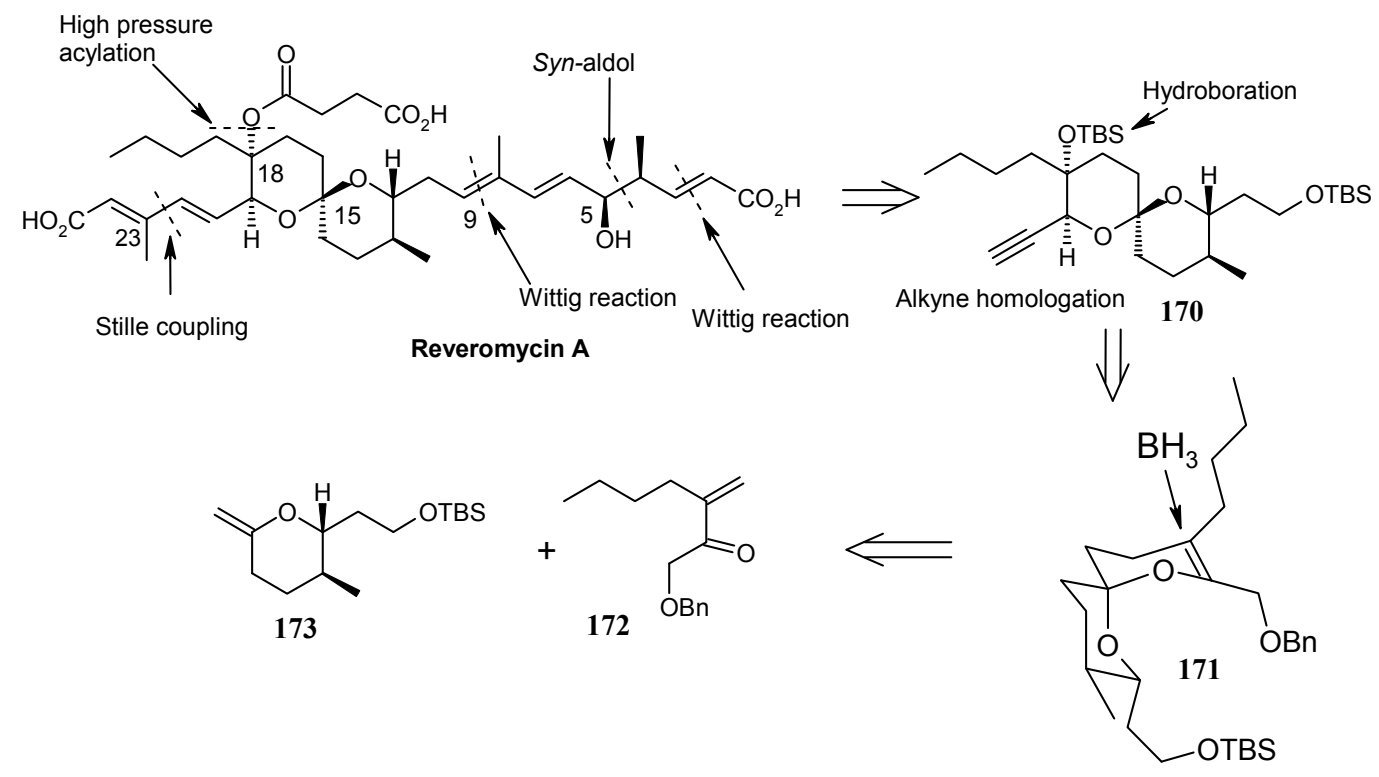


It is revealed that spiroketal $\mathbf{1 7 0}$ is the core unit, which can be obtained from unsaturated spiroketal $\mathbf{1 7 1}$ by regio and stereoselective hydroboration followed by alkyne homologation. Unit $\mathbf{1 7 1}$ in turn can be obtained by an inverse electron demand hetero Diels-Alder reaction between 172 and 173 [93]. This reaction will fix the stereochemistry at the spiro center by an axial approach of the carbonyl oxygen in the HDA transition state [94]. The strereochemistry at C-18 and C-19 can be set by hydroboration and oxidation sequence to circumvent the thermodynamic lability of the spiroketal present in reveromycin A.

Scheme 40. Synthesis of unsaturated spiroketal fragment 171.

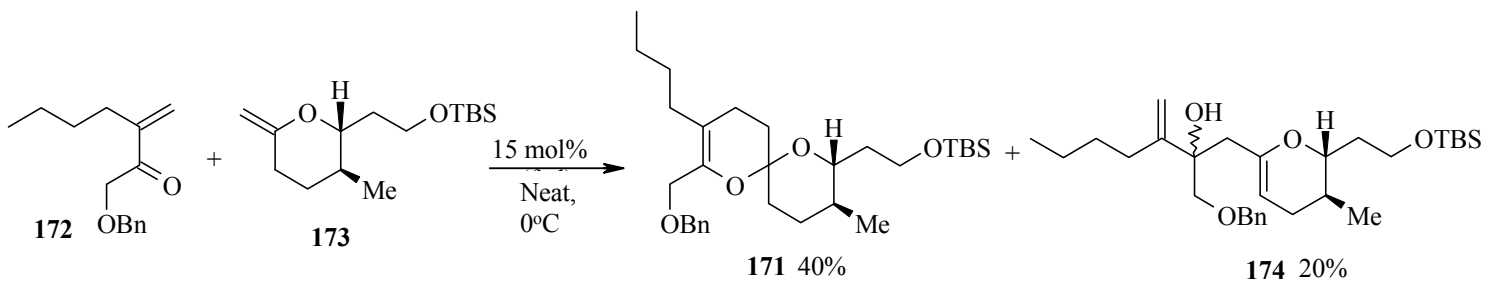

Thus, hetero-Diels Alder reaction between dianophile 173 and diene 172 in presence of 15 mol \% $\mathrm{Eu}(\mathrm{fod})_{3}$ affords the desired spiroketal $\mathbf{1 7 1}$ as one diastereoisomer, along with the byproduct diastereomeric mixture 174, resulting from an ene reaction (Scheme 40). The compound 171 on hydroboration followed by oxidation affords the tertiary alcohol $\mathbf{1 7 5}$ as a single isomer. Compound $\mathbf{1 7 6}$ is obtained by protection, deprotection sequence.

Oxidation of 176 and alkyne formation following the Bestmann protocol gives compound 170 [95]. Compound 177, prepared from $\mathbf{1 7 0}$ in four steps (Scheme 41), is then converted to $\mathbf{1 7 8}$ by a reduction and oxidation sequence (Scheme 42). This, after aldol reaction with 179 gives the desired synpropionate 180, which when exposed to $\mathrm{NaBH}_{4}$ gives the diol $\mathbf{1 8 1}$ after reductive cleavage of auxiliary group [96].

Scheme 41. Synthesis of spiroketal 177.

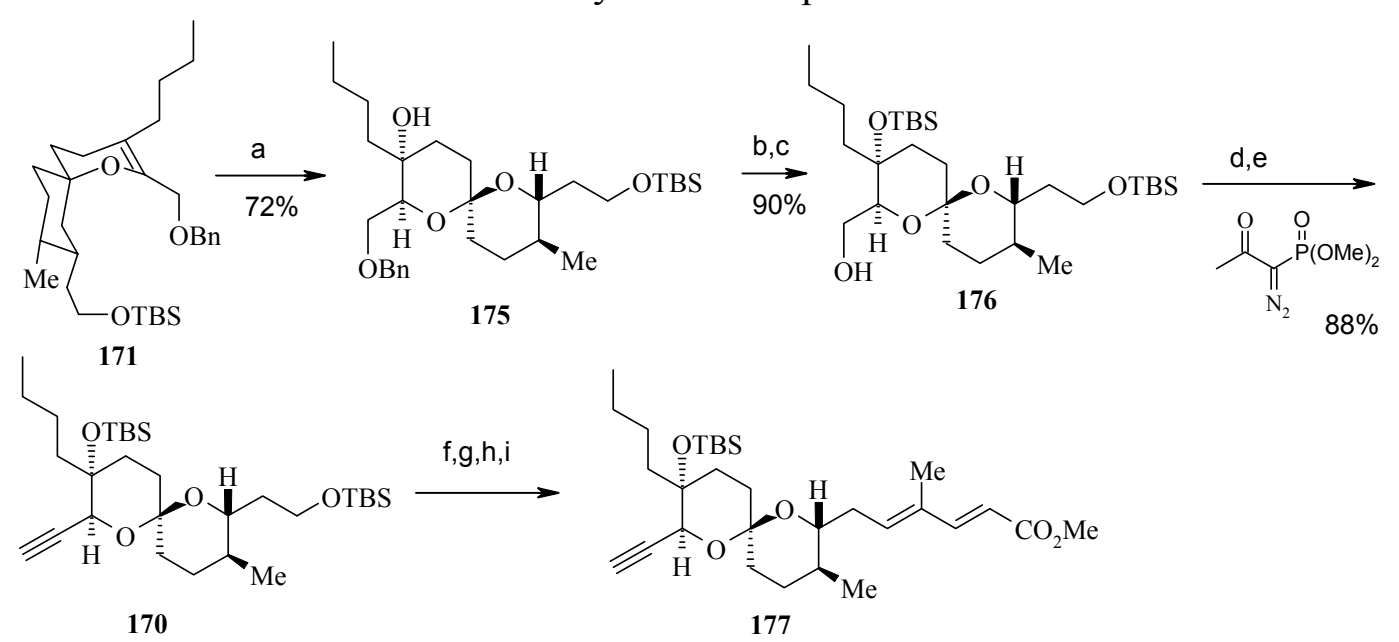

Reagents and conditions: (a) $\mathrm{BH}_{3}$.THF, $\mathrm{H}_{2} \mathrm{O}_{2}$, NaOH, 72\%; (b) TBSOTf, 2,6-lutidine; (c) $\mathrm{H}_{2}, \mathrm{Pd}(\mathrm{OH})_{2}, 90 \%$; (d) DMP; (e) $\mathrm{MeOH}, \mathrm{K}_{2} \mathrm{CO}_{3}, 88 \%$; (f) TBAF, THF, rt; (g) DMP; (h) $\mathrm{Ph}_{3}=\mathrm{C}\left(\mathrm{Me}\right.$ )CHO; (i) $\mathrm{Ph}_{3} \mathrm{P}=\mathrm{CHCO}_{2} \mathrm{Me}$, $70 \%$. 
Scheme 42. Synthesis of spiroketal 181.

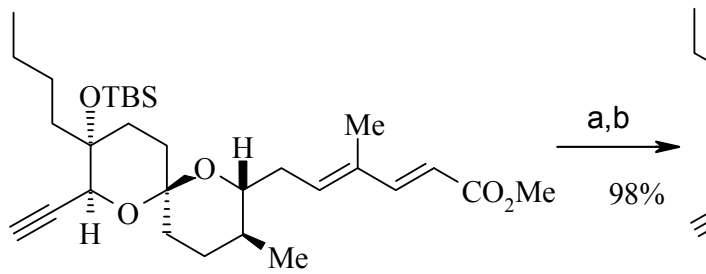

177

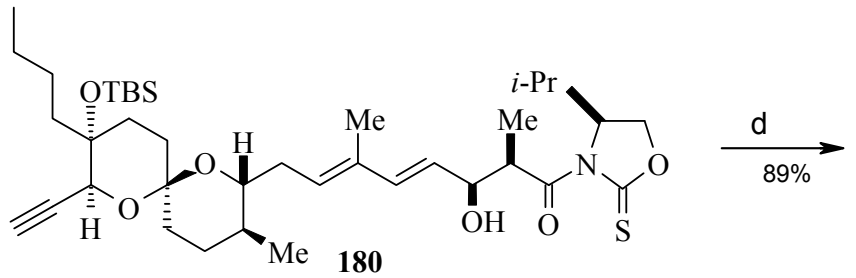
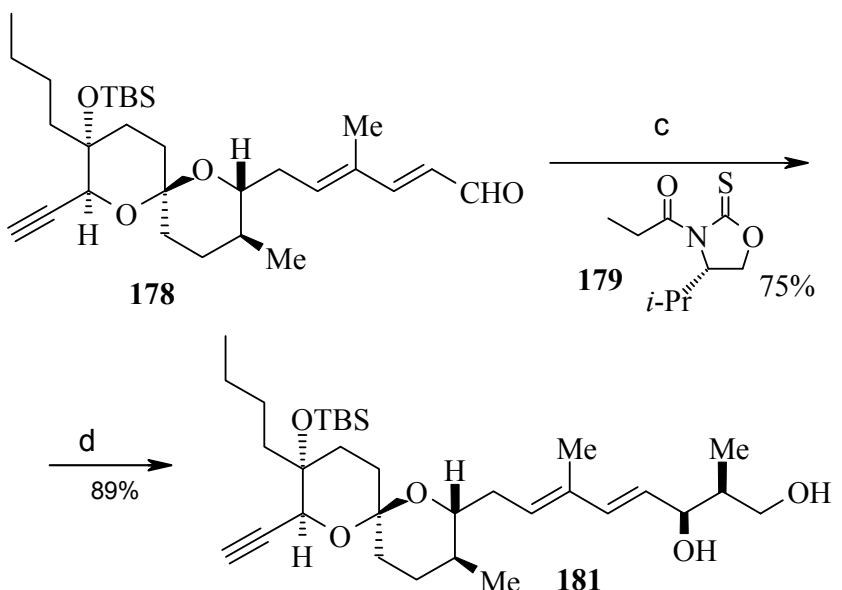

Reagents and conditions: (a) DIBALH; (b) DMP; (c) $\mathrm{Sn}(\mathrm{OTf})_{2}, N$-ethylpiperidine; (d) $\mathrm{NaBH}_{4}, \mathrm{THF}, \mathrm{H}_{2} \mathrm{O}, 89 \%$.

Scheme 43. Synthesis of vinyl stannane 186.

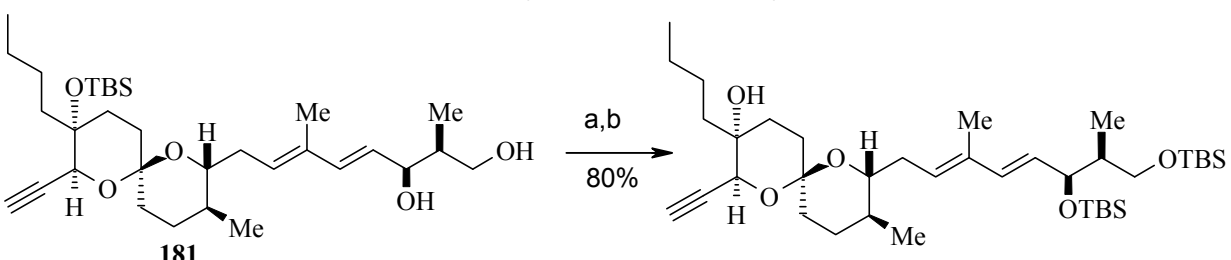

182

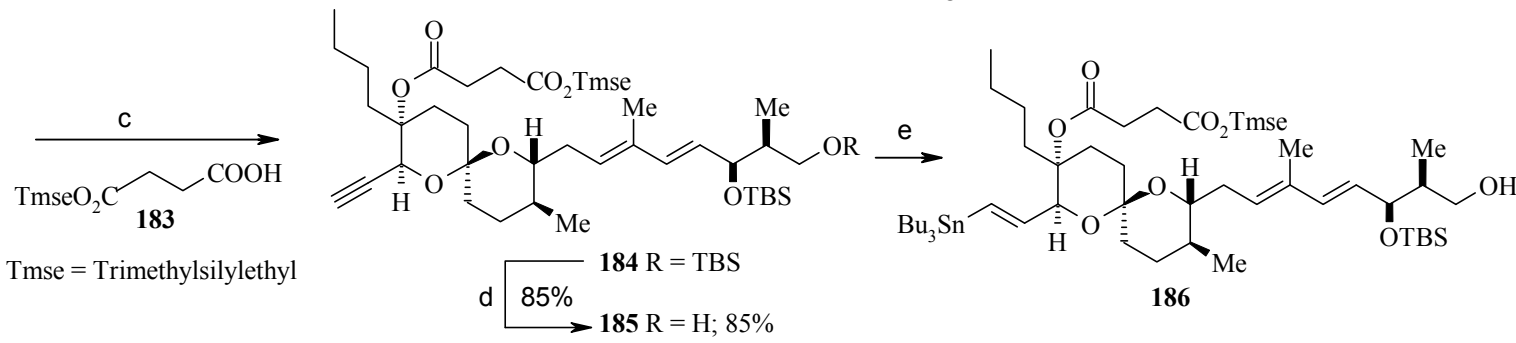

Reagents and conditions: (a) TBAF, $50{ }^{\circ} \mathrm{C}$; (b) TBSCl, imidazole; (c) 183, $0.4 \mathrm{Gpa}$, DCC, DMAP, $\mathrm{CH}_{2} \mathrm{Cl}_{2}$, 95\%; (d) HF.Py., Py, THF, $85 \%$; (e) $\mathrm{Bu}_{3} \mathrm{SnH}, \mathrm{Pd}\left(\mathrm{Ph}_{3} \mathrm{P}\right)_{2} \mathrm{Cl}_{2}$.

Scheme 44. Total synthesis of reveromycin A, 190.

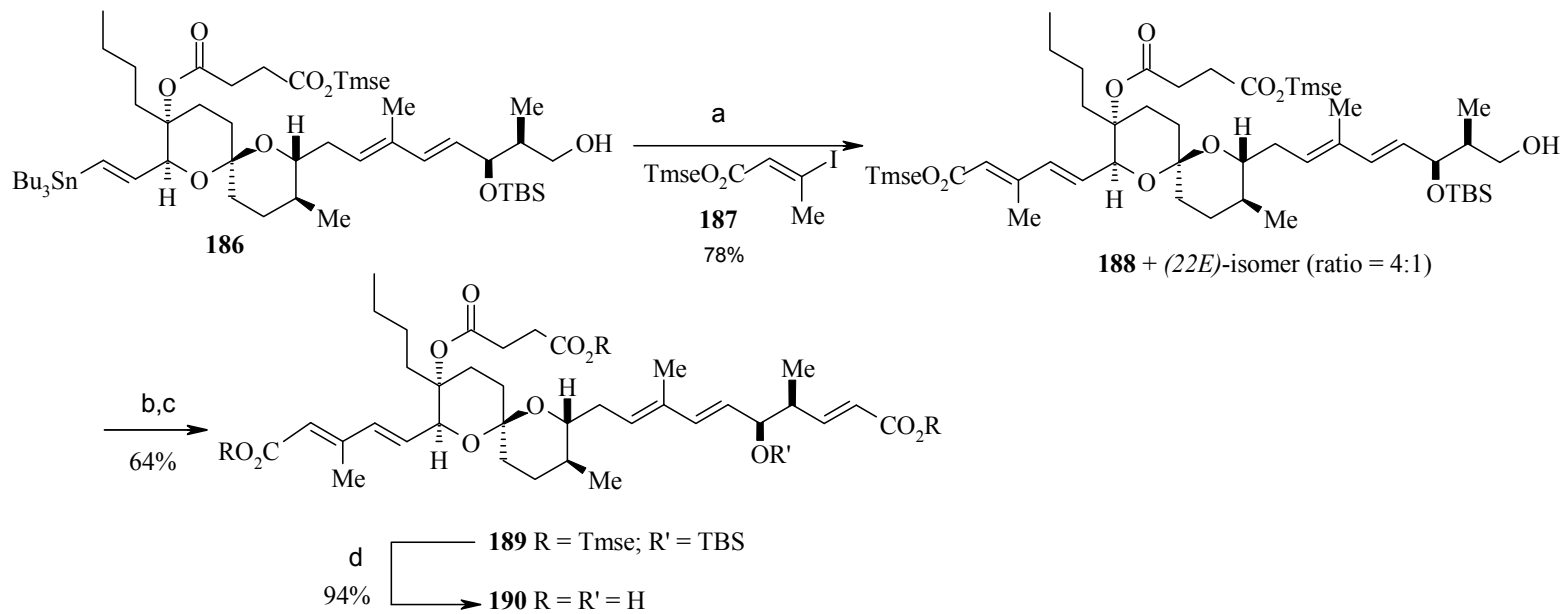

Reagents and conditions: (a) 187, $\mathrm{Pd}_{2}(\mathrm{dba})_{3}$, TFP, NMP, $60{ }^{\circ} \mathrm{C}, 78 \%$; (b) DMP; (c) $\mathrm{Ph}_{3} \mathrm{P}=\mathrm{CHCO}_{2} \mathrm{Tmse}$, 64\%; (d) TBAF, DMF, 94\%. 
Deprotection of the C-18 TBS ether and selective primary/secondary alcohol protection yields bisTBS ether 182 (Scheme 43) whose hindered tertiary alcohol is acylated at higher pressure using the Shimizu and Nakata procedure to give ester 184 [97]. Selective deprotection of the primary alcohol in 184 and subsequent hydrostannylation of the alkyne in 185 gives the vinyl stannane 186 [98]. Finally, Stille coupling between stannane 186 and vinyl iodide 187 affords the required tetraene 188 along with a small amount of $22 E$-isomer. Oxidation of the free primary alcohol of $\mathbf{1 8 7}$ and then Wittig reaction affords the fully protected reveromycin A, 189, which on deprotection gives reveromycin A, 190 in high yield (Scheme 44) [99].

\subsubsection{Shimizu and Nakata Synthesis}

Shimizu and Nakata have synthesized the reveromycin A by stereocontrolled intermolecular spirocyclisation of an appropriately substituted ketone [100]. The retrosynthetic analysis of the reveromycin A is shown in Scheme 45. The spiroketal 191 can be obtained from ketone 194, which in turn can be obtained from Weinreb amide 195 and alkyne 196.

Scheme 45. Retrosynthetic analysis of the reveromycin A.
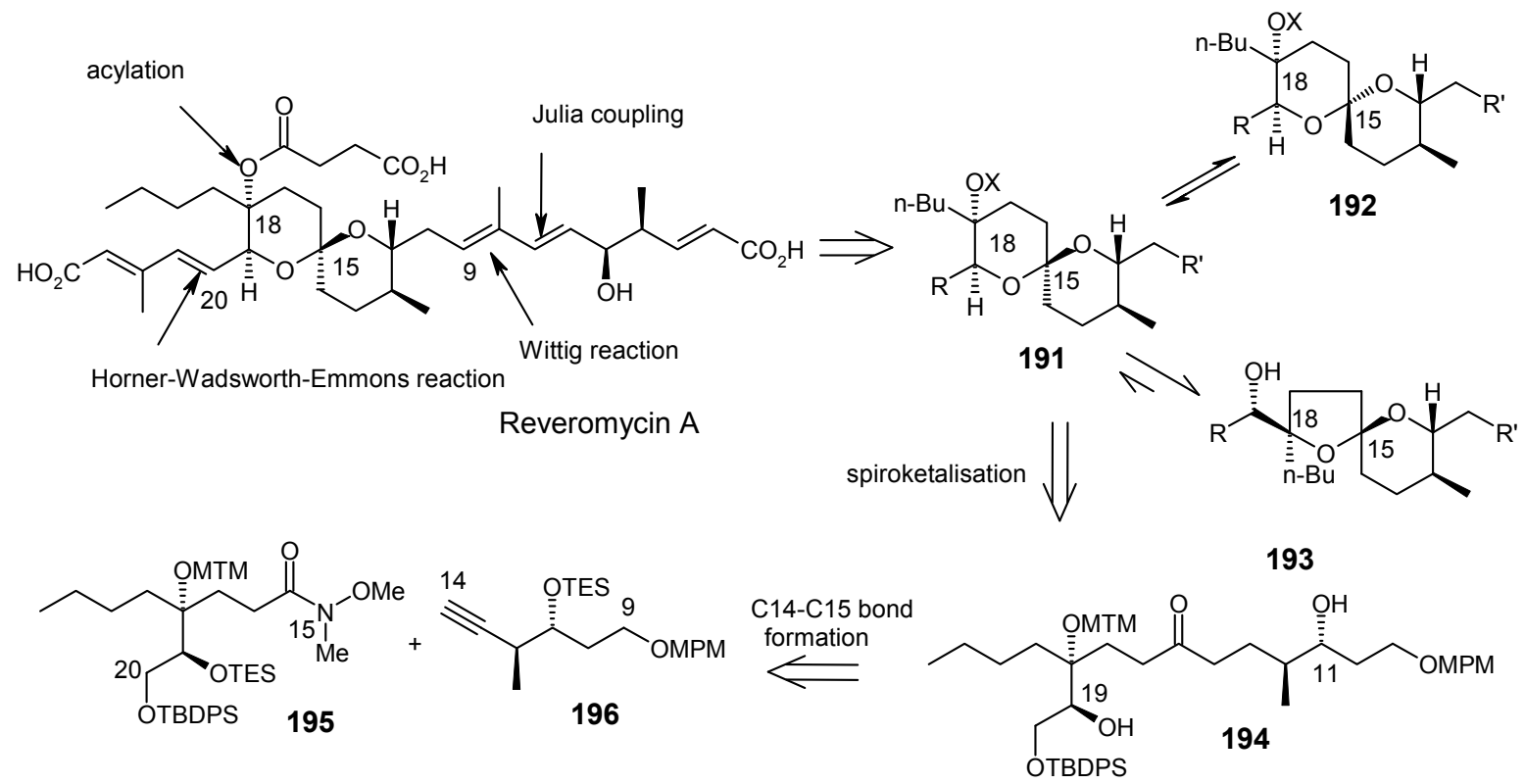

The spiroketal core unit $\mathbf{1 9 7}$ is prepared by condensation of Weinreb amide $\mathbf{1 9 5}$ and lithiated alkyne 196 followed by hydrogenation (Scheme 46). Selective deprotection of two TES groups furnishes the spiroketals 198 and 199. The MTM group of 198 is deprotected and then acylated at higher pressure to give 203 [101]. 
Scheme 46. Synthesis of spiroketals 198 and 199.

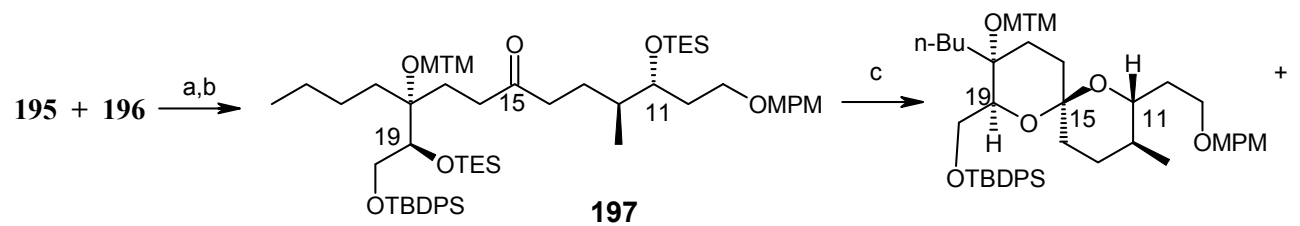

197

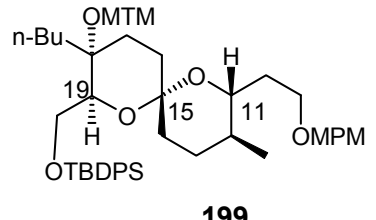

199

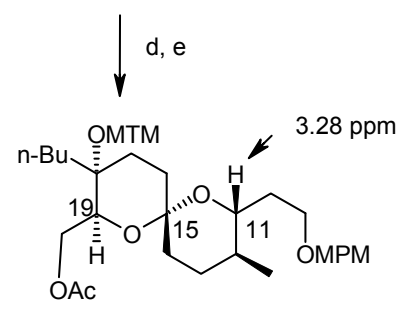

201

Reagents and conditions: (a) $n$-BuLi, THF, $0{ }^{\circ} \mathrm{C}$ to rt, $93 \%$, (b) $\mathrm{H}_{2}, \mathrm{Pd} / \mathrm{C}$, EtOAc, rt, $99 \%$, (c) CSA, $\mathrm{CHCl}_{3}$, $\mathrm{MeOH}, 0^{\circ} \mathrm{C}$ to rt, (198, 54\%; 199, 27\%), (d) TBAF, THF, rt, (e) $\mathrm{Ac}_{2} \mathrm{O}, \mathrm{Py}, \mathrm{CH}_{2} \mathrm{Cl}_{2}$, rt ,98\%, two steps).

Scheme 47. Synthesis of spiroketal 205.

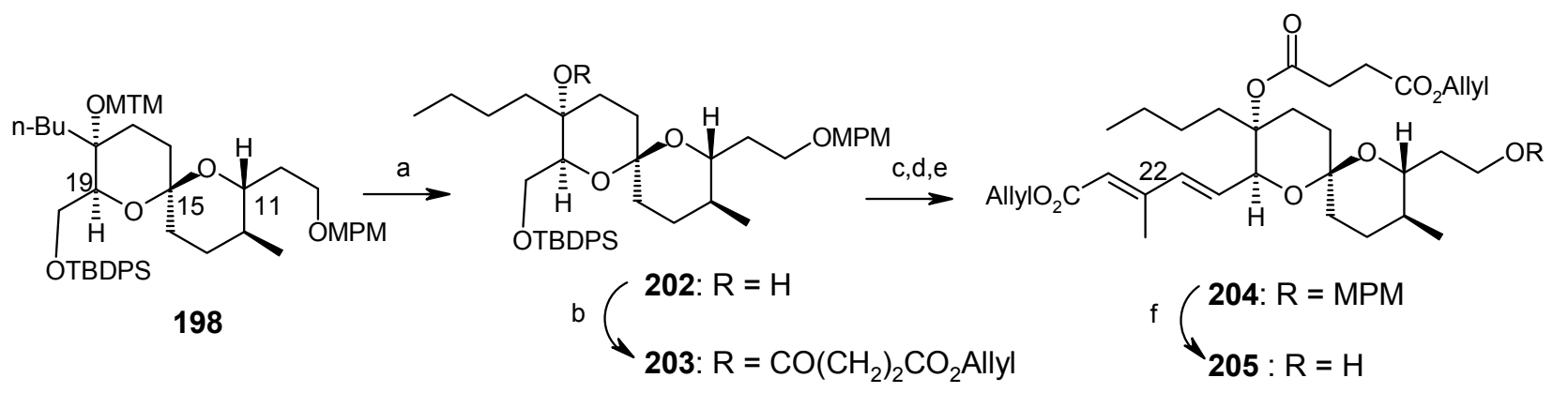

Reagents and conditions: (a) MeI, $\mathrm{NaHCO}_{3}, \mathrm{Me}_{2} \mathrm{CO}, \mathrm{H}_{2} \mathrm{O}, 60{ }^{\circ} \mathrm{C}, 96 \%$, (b) mono-allyl succinate, DCC, DMAP, $\mathrm{CH}_{2} \mathrm{Cl}_{2}, 1.5 \mathrm{Gpa}$, rt, 24h, 83\%, (c) HF.Py-Py (1:4), THF, rt, 92\%, (d) Dess-Martin periodinane, MS4A, $\mathrm{CH}_{2} \mathrm{Cl}_{2}$, rt, (e) diethyl (2E)-3-allyloxycarbonyl)-2-methylprop-2-enylphosphonate, LHMDS, HMPA, THF, -78 to $0{ }^{\circ} \mathrm{C}, 82 \%$, two steps; $22 E: 22 Z=14: 1$ ); (f) DDQ, $\mathrm{CH}_{2} \mathrm{Cl}_{2}, \mathrm{H}_{2} \mathrm{O}$, rt, $89 \%$.

Scheme 48. Conversion of spiroketal 199 to 205.

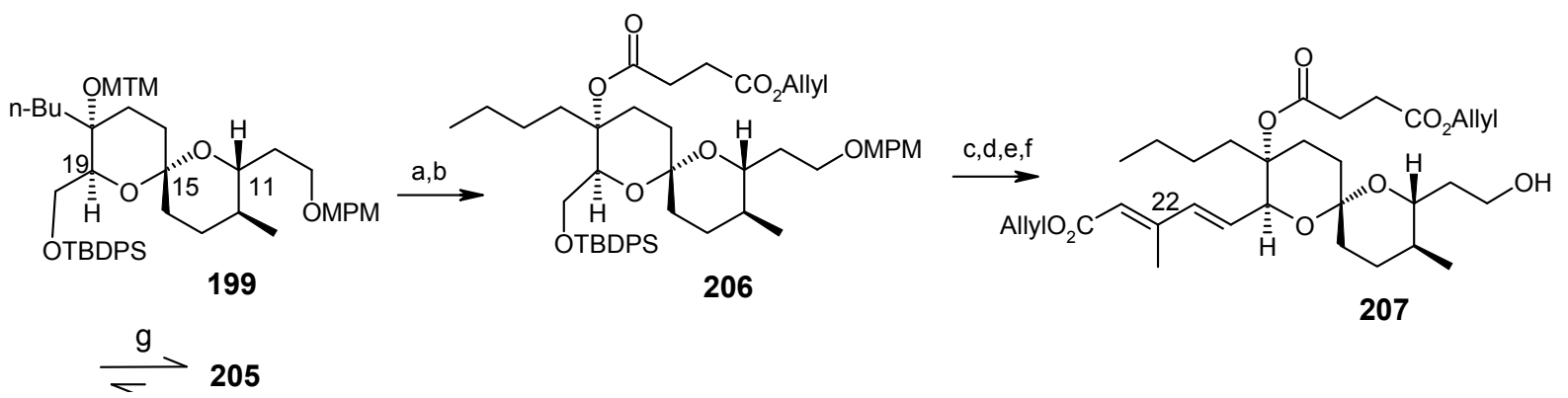

Reagents and conditions: (a) MeI, $\mathrm{NaHCO}_{3}, \mathrm{Me}_{2} \mathrm{CO}, \mathrm{H}_{2} \mathrm{O}, 60{ }^{\circ} \mathrm{C}$ (91\%), (b) mono-allyl succinate, DCC, DMAP, $\mathrm{CH}_{2} \mathrm{Cl}_{2}, 1.5 \mathrm{Gpa}$, rt, 24h (76\%), (c) HF.Py-Py (1:4), THF, rt, (95\%), (d) Dess-Martin periodinane, MS4A, $\mathrm{CH}_{2} \mathrm{Cl}_{2}$, rt, (e) diethyl (2E)-3-allyloxycarbonyl)-2-methylprop-2-enylphosphonate, LHMDS, HMPA, THF, -78 to $0{ }^{\circ} \mathrm{C}(88 \%$, two steps; $22 E: 22 Z=50: 1)$; (f) DDQ, $\mathrm{CH}_{2} \mathrm{Cl}_{2}, \mathrm{H}_{2} \mathrm{O}$, rt $(88 \%)$, (g) 0.1 equiv. CSA, $\mathrm{CHCl}_{3}, \mathrm{MeOH}, \mathrm{rt}, 24 \mathrm{~h}, 2$ times repeated $(19,82 \% ; 21,8 \%)$. 
Deprotection of silyl group, followed by Dess-Martin oxidation and a Horner-Wadsworth-Emmons reaction gives the desired $(20 E, 22 E)$-dienoic esters $\mathbf{2 0 4}$, along with its $(20 E, 22 Z)$-isomer, with a ratio of 14:1. Deprotection of MPM from 204 yields 205 (Scheme 47). The unnatural spiroketal 199 is then converted to 207 using the same reaction sequence as earlier $(\mathbf{1 9 8} \rightarrow \mathbf{2 0 4})$. Epimerisation of 207 with $\mathrm{CSA}$ in $\mathrm{CHCl}_{3}-\mathrm{MeOH}$ gives 205 (Scheme 48). Finally the molecule is synthesized using four important reactions, namely a Dess-Martin oxidation, a Wittig olefination, a modified Mitsunobu reaction and a Julia olefination, as shown in Scheme 49 [102, 103].

Scheme 49. Total synthesis of reveromycin A.
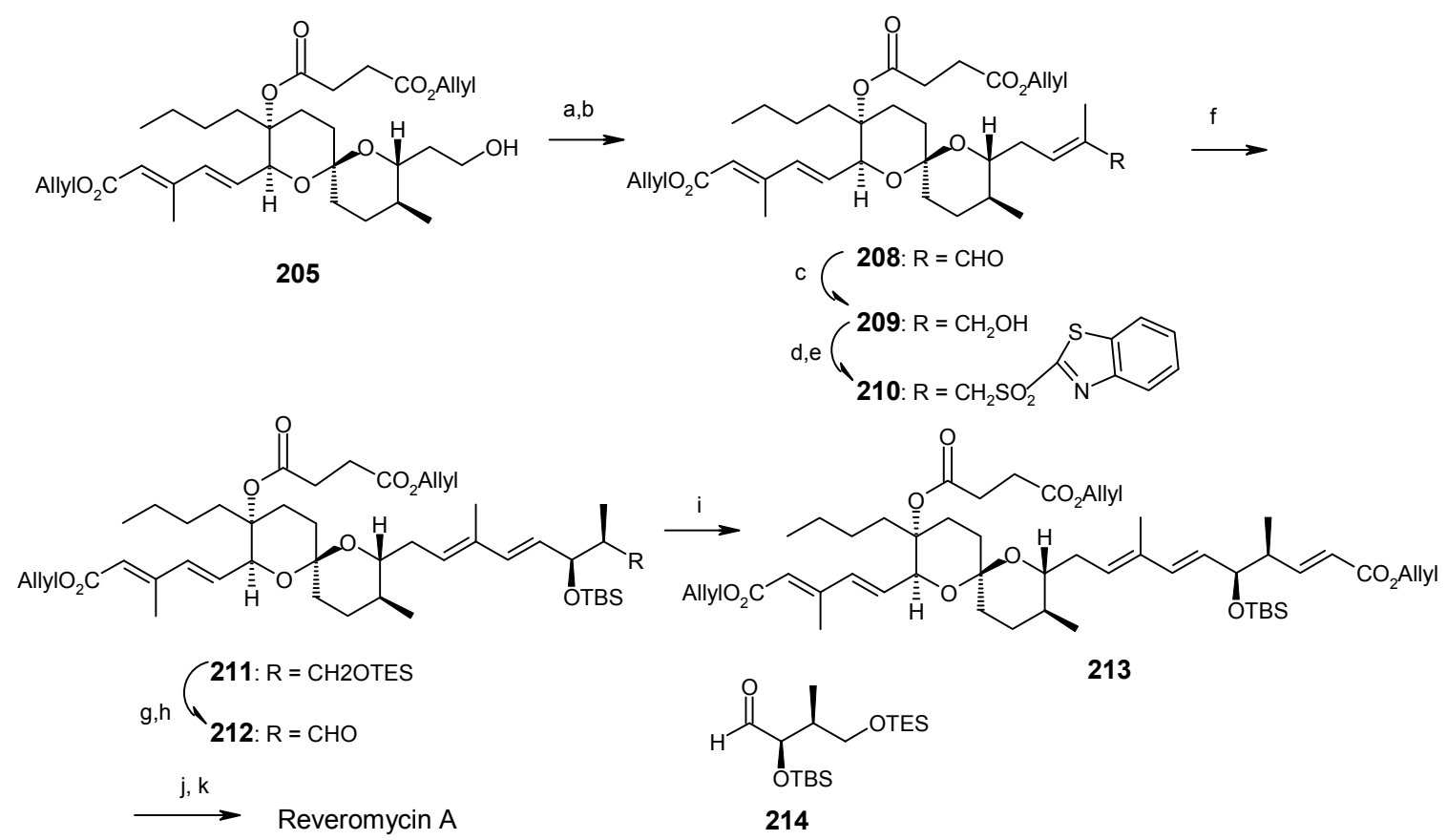

Reagents and conditions: (a) Dess-Martin periodinane, MS4A, $\mathrm{CH}_{2} \mathrm{Cl}_{2}$, rt, (b) $\mathrm{Ph}_{3} \mathrm{P}=\mathrm{C}(\mathrm{Me}) \mathrm{CHO}$, toluene, $110{ }^{\circ} \mathrm{C}$, (88\%, two steps), (c) $\mathrm{Zn}\left(\mathrm{BH}_{4}\right)_{2}, \mathrm{Et}_{2} \mathrm{O}, 0{ }^{\circ} \mathrm{C}, 99 \%$; (d) 2-mercaptobenzenzothiazole, $n$-Bu $3 \mathrm{P}, \mathrm{TMAD}$, benzene, $5{ }^{\circ} \mathrm{C}$ to rt, $87 \%$; (e), $\mathrm{Mo}_{7} \mathrm{O}_{24}\left(\mathrm{NH}_{4}\right)_{6} \cdot 4 \mathrm{H}_{2} \mathrm{O}, \mathrm{H}_{2} \mathrm{O}$, EtOH, $0{ }^{\circ} \mathrm{C}$ to rt, $79 \%$; (f) LHMDS, 214, THF, -78 ${ }^{\circ} \mathrm{C}$, to rt $(90 \%)$, (g) PPTS, $\mathrm{CHCl}_{3}, \mathrm{MeOH}, 0{ }^{\circ} \mathrm{C}$, (h) Dess-Martin periodinane, MS4A, $\mathrm{CH}_{2} \mathrm{Cl}_{2}, \mathrm{rt}$ (91\%), (i) $\mathrm{Ph}_{3} \mathrm{P}=\mathrm{CHCO}_{2}$ allyl, toluene, $80{ }^{\circ} \mathrm{C}$, (98\%); (j) $\mathrm{Pd}\left(\mathrm{Ph}_{3} \mathrm{P}\right)_{4}, \mathrm{Ph}_{3} \mathrm{P}$, pyrrolidine, $\mathrm{CH}_{2} \mathrm{Cl}_{2}, 0{ }^{\circ} \mathrm{C}$ to $\mathrm{rt}$, (k) TBAF. $3 \mathrm{H}_{2} \mathrm{O}, \mathrm{DMF}$, rt (71\%, two steps).

The two approaches for the synthesis of reveromycin A differ in their spiroketal synthesis. The Rizzacasa group applied the Lewis acid catalyzed inverse electron demand hetero-Diels-Alder (HAD) reaction followed by hydroboration/oxidation sequence for spiroketal synthesis whereas the Shimizu and Nakata group utilized the acid mediated spiroketalisation of suitably fuctionalized keto alcohol. In both the cases side products decreases the yield of the spiroketal moiety. The advantage of the Rizzacasa synthesis is that it avoids the use of large number of different protecting groups because the synthesis of core spiroketal unit is based on hetero-Diels-Alder strategy. It is also shorter (23 steps) than the Shimizu and Nakata approach (27 steps). 


\subsection{Total synthesis of (-)-Reveromycin B}

Reveromycin B, like Reveromycin A is a member of a novel family of bioactive spiroketalcontaining natural product isolated from a soil actinomycete belonging to the Streptomyces genus [90]. This is an inhibitor of the mitogenic activity of epidermal growth factor (EFG) and may represent a new class of antitumor agents [104].

\subsubsection{Rizzacasa Synthesis}

Rizzacasa and coworkers describes a novel, convergent, and stereoselective total synthesis of (-)reveromycin B [105]. The retrosynthetic analysis is shown in Scheme 50. This analysis reveals that intermediate $\mathbf{2 1 5}$ is the key unit for the synthesis of (-)-reveromycin B. Other side chain units can be synthesized by $\operatorname{Pd}(0)$-mediated cross coupling, acylation, Wittig and syn-aldol reaction, as shown in Scheme 50. Spiroketal unit 215 can be obtained from hetero-Diels-Alder reaction [106].

Scheme 50. Retrosynthetic analysis of (-)-reveromycin B.

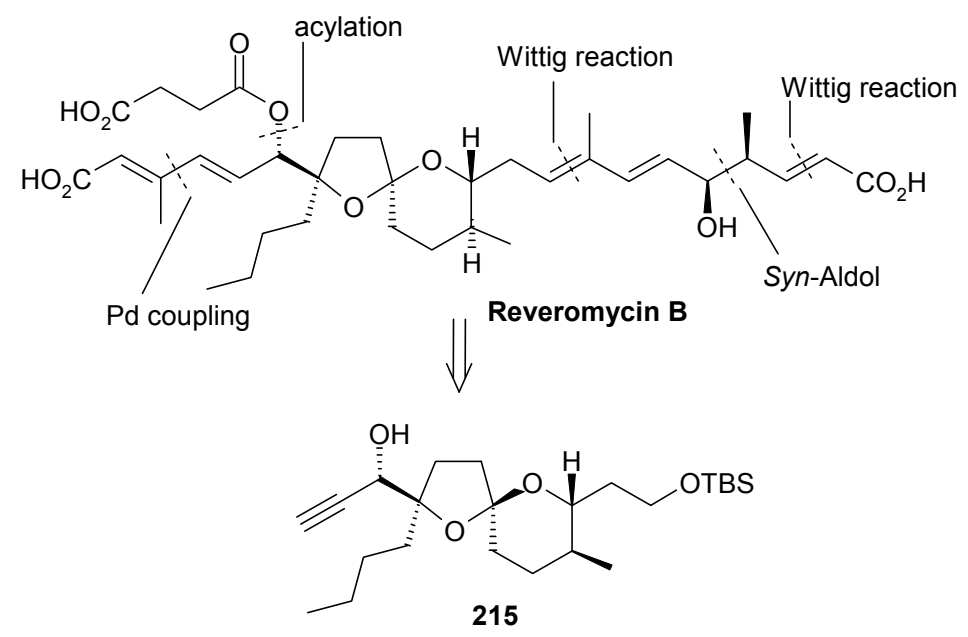

Scheme 51. Synthesis of spiroketal 219.

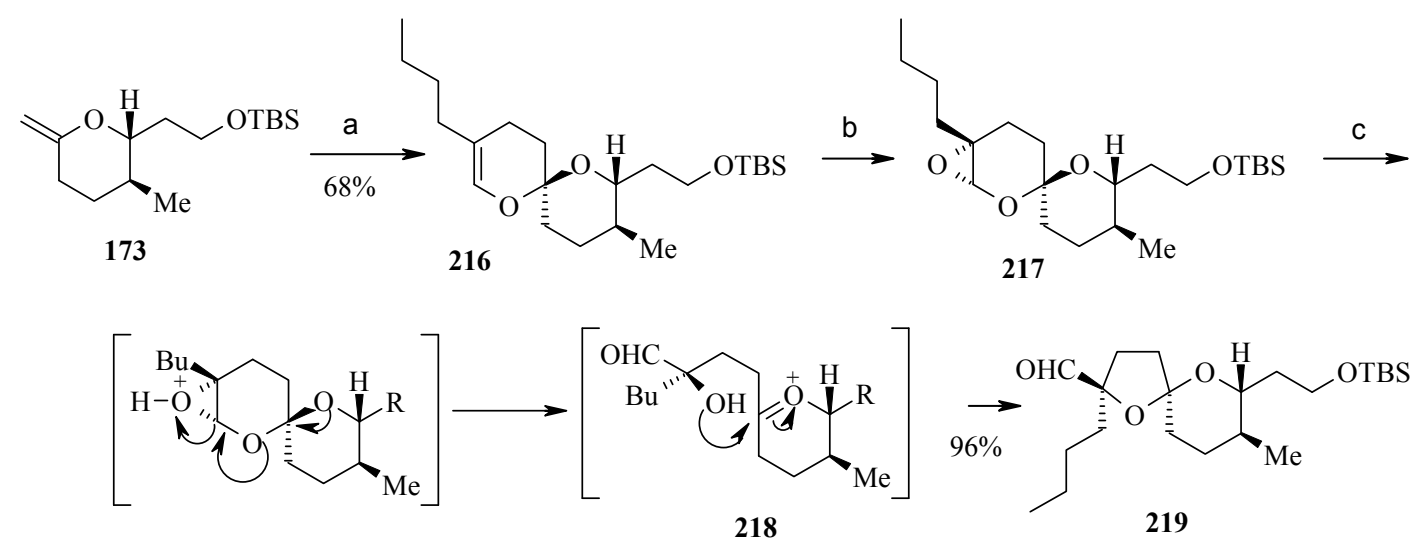

Reagents and conditions: (a) Butylacrolein, $\mathrm{K}_{2} \mathrm{CO}_{3}, 110{ }^{\circ} \mathrm{C}$; (b) dimethyldioxirane, $\mathrm{CH}_{2} \mathrm{Cl}_{2}, 0{ }^{\circ} \mathrm{C}$; (c) $\mathrm{CSA} \mathrm{CH}_{2} \mathrm{Cl}_{2}, \mathrm{rt}$. 
The synthesis of reveromycin B can be illustrated by a [4+2] cycloaddition reaction between the methylenepyran 173 and butylacrolein in the presence of $\mathrm{K}_{2} \mathrm{CO}_{3}$. The reaction proceeds smoothly at a slightly higher temperature $\left(110^{\circ} \mathrm{C}\right)$ than reported previously to give the 6,6-spiroketel 216 in good yield as one diastereoisomer (Scheme 51) [83, 106]. Epoxidation of the resulting enol ether 216 with dimethyldioxirane provides the labile epoxide 217, which rearranges to thermodynamically most stable 5,6-spiroketal 219 with the desired C-18 stereochemistry in 219 upon treatment with CSA [107].

Addition of lithium trimethylsilylacetylide to aldehyde 219 affords the alkyne 220 with the incorrect stereochemistry at C-19 as the only product, which on oxidation followed by reduction of the resultant ketone with L-Selectride and removal of the TMS group affords the desired alcohol 221 as a 9:1 mixture [106]. This is then converted to alcohol 222 by a protection, deprotection sequence (Scheme 52).

Scheme 52. Conversion of spiroketal 219 to 222.

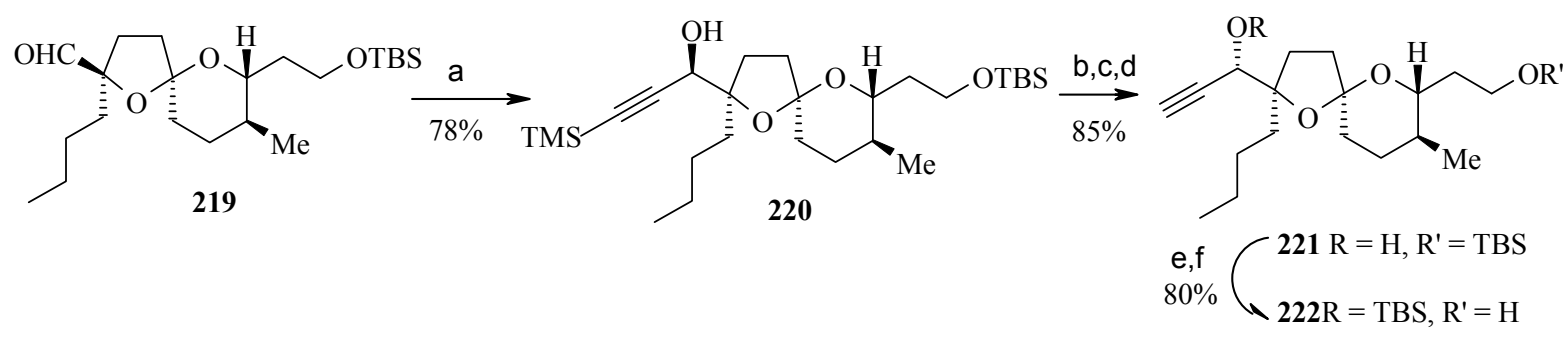

Reagents and conditions: (a) TMSC $\equiv \mathrm{CLi}$, THF, $-78{ }^{\circ} \mathrm{C}, 78 \%$; (b) Dess-Martin reagent, $\mathrm{CH}_{2} \mathrm{Cl}_{2}$; (c) $\mathrm{L}-$ selectride, THF, $-78{ }^{\circ} \mathrm{C}$; (d) $\mathrm{K}_{2} \mathrm{CO}_{3}, \mathrm{MeOH}$, rt, 85\%; (e) TBSOTf, 2,6-lutidine, $\mathrm{CH}_{2} \mathrm{Cl}_{2},-40{ }^{\circ} \mathrm{C}$; (f) HF.Py/Py, THF, rt, $80 \%$.

Scheme 53. Conversion of 222 to 227.

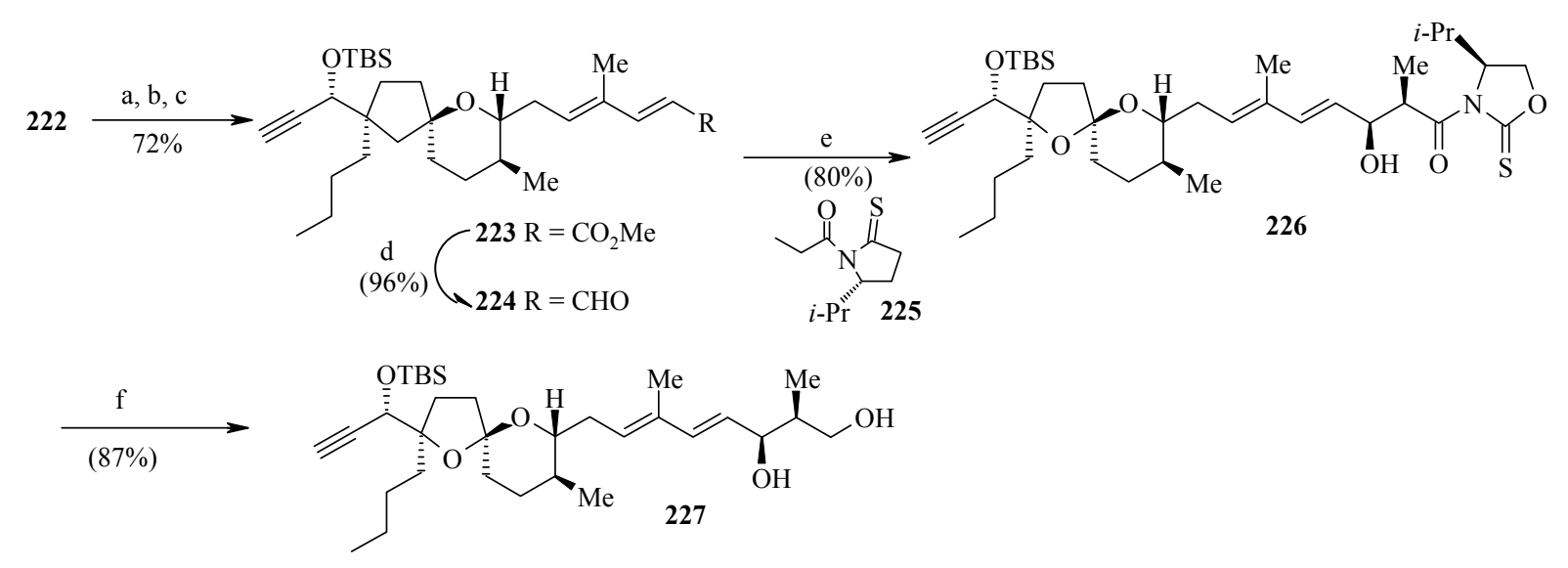

Reagents and conditions: (a) Dess-Martin periodinane, $\mathrm{CH}_{2} \mathrm{Cl}_{2}$; (b) $\mathrm{Ph}_{3} \mathrm{P}=\mathrm{C}(\mathrm{Me}) \mathrm{CHO}, \mathrm{C}_{6} \mathrm{H}_{5} \mathrm{Cl}, 100{ }^{\circ} \mathrm{C}, 72 \mathrm{~h}$; (c) $\mathrm{Ph}_{3} \mathrm{P}=\mathrm{CHCO}_{2} \mathrm{Me}$, benzene, reflux, 24h; (d) (i) DIBALH, $\mathrm{CH}_{2} \mathrm{Cl}_{2},-78{ }^{\circ} \mathrm{C}$; (ii) Dess-Martin periodinane, $\mathrm{Py}, \mathrm{CH}_{2} \mathrm{Cl}_{2}$; (e) oxazolidine-2-thione 225, $\mathrm{Sn}(\mathrm{OTf})_{2}, \mathrm{~N}$-ethylpiperidine, $\mathrm{CH}_{2} \mathrm{Cl}_{2},-55{ }^{\circ} \mathrm{C}$, then aldehyde 224, $-78{ }^{\circ} \mathrm{C}$; (f) $\mathrm{NaBH}$, $\mathrm{THF}$, $\mathrm{H}_{2} \mathrm{O}$. 
Oxidation of 222 and sequential Wittig reactions give the desired diene ester 223 in good overall yield. Reduction of ester $\mathbf{2 2 3}$ followed by oxidation affords the labile aldehyde $\mathbf{2 2 4}$. The stereochemistry at C-4 and C-5 is installed by tin mediated asymmetric aldol reaction of $\mathbf{2 2 4}$ with 1,3oxazolidine-2-thione $\mathbf{2 2 5}$ as chiral auxiliary. The resulting aldol product $\mathbf{2 2 6}$ is then converted to free alcohol 227 after removal of the chiral auxiliary group (Scheme 53).

Scheme 54. Synthesis of spiroketal 232 from 227.

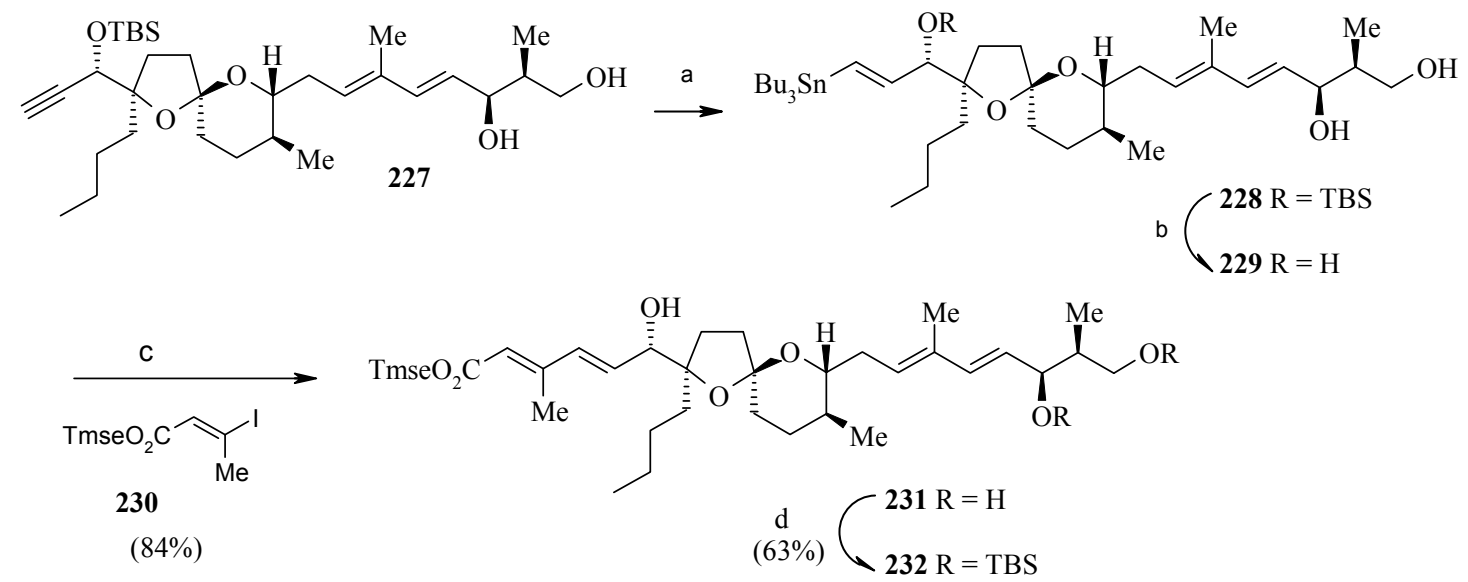

Reagents and conditions: (a) $\mathrm{Bu}_{3} \mathrm{SnH}$, cat. $\left(\mathrm{Ph}_{3} \mathrm{P}\right)_{2} \mathrm{PdCl}_{2}, \mathrm{CH}_{2} \mathrm{Cl}_{2}, 0{ }^{\circ} \mathrm{C}$, $1 \mathrm{~h}$; (b) TBAF, THF, $50{ }^{\circ} \mathrm{C}, 16 \mathrm{~h}$; (c) cat. $\mathrm{Pd}_{2}(\mathrm{dba})_{2}$, THF, NMP, $60{ }^{\circ} \mathrm{C}, 30 \mathrm{~min}$; (d) TBSCl, imidazole, DMF, $50{ }^{\circ} \mathrm{C}, 3 \mathrm{~h}$; Tmse $=-\mathrm{CH}_{2} \mathrm{CH}_{2} \mathrm{SiMe}_{3}$.

Scheme 55. Total synthesis of reveromycin B.

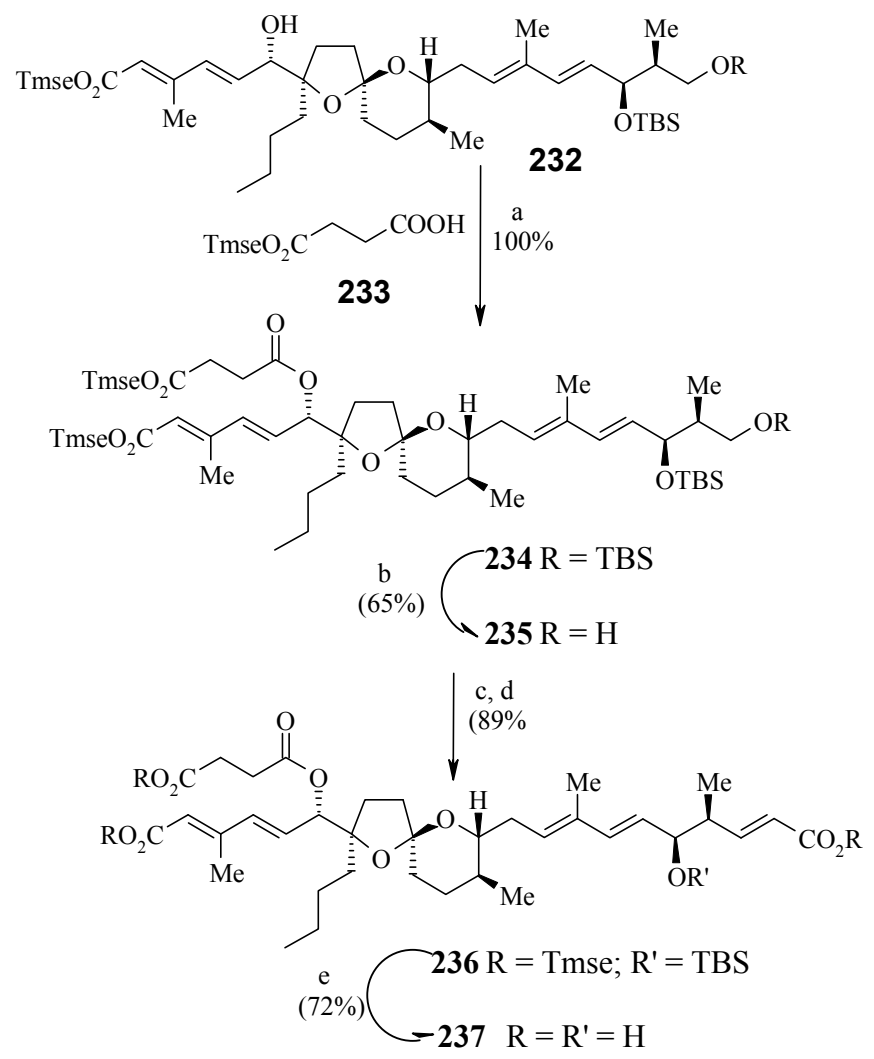

Reagents and conditions: (a) DCC, cat.DMAP, $35{ }^{\circ} \mathrm{C}, 24 \mathrm{~h}$; (b) HF.Py/Py, THF, rt., 7h; (c) Dess-Martin periodinane, $\mathrm{Py}, \mathrm{CH}_{2} \mathrm{Cl}_{2}$, rt, $1 \mathrm{~h}$; (d) $\mathrm{Ph}_{3} \mathrm{P}=\mathrm{CHCO}_{2}$ Tmse, $\mathrm{CH}_{2} \mathrm{Cl}_{2}$, rt, 24h; (e) TBAF, DMF, rt, 48h. 
The diol 227 is converted to stannate $\mathbf{2 2 8}$ by palladium-catalyzed hydrostannylation [108]. Removal of the hindered C-19 OTBS group furnishes triol 229, which is subjected to Stille cross-coupling with the vinyl iodide $\mathbf{2 3 0}$ under conditions reported by Farina to give tetraene $\mathbf{2 3 1}$ in excellent yield (Scheme 54) $[109,110]$. It is observed that the C-19 OTBS group is important for hydrostannylation, whereas Stille coupling is most effective with a free hydroxy group at C-19. The primary and secondary hydroxyl groups of $\mathbf{2 3 1}$ are silylated and then esterified to yield ester 234 [111]. Removal of primary TBS group in $\mathbf{2 3 4}$ followed by oxidation and subsequent Wittig reaction gives protected reveromycin B, 236, which upon deprotection of all protecting groups afford reveromycin B (237, Scheme 55).

\subsubsection{Theodorakis Synthesis}

Theodorakis and coworkers have synthesized reveromycin B using Negishi and Kishi-Nozaki coupling reactions [112]. The retrosynthetic analysis of the molecule reveals that iodides $\mathbf{2 3 8 , 2 3 9}$ and alkyne $\mathbf{2 4 0}$ are the main units for the construction of the reveromycin 239. Alkyne $\mathbf{2 4 0}$ further can be disconnected to unit $\mathbf{2 4 1}$ and $\mathbf{2 4 2}$ as shown in Scheme 56.

Scheme 56. Retrosynthetic analysis of (-)-reveromycin B.
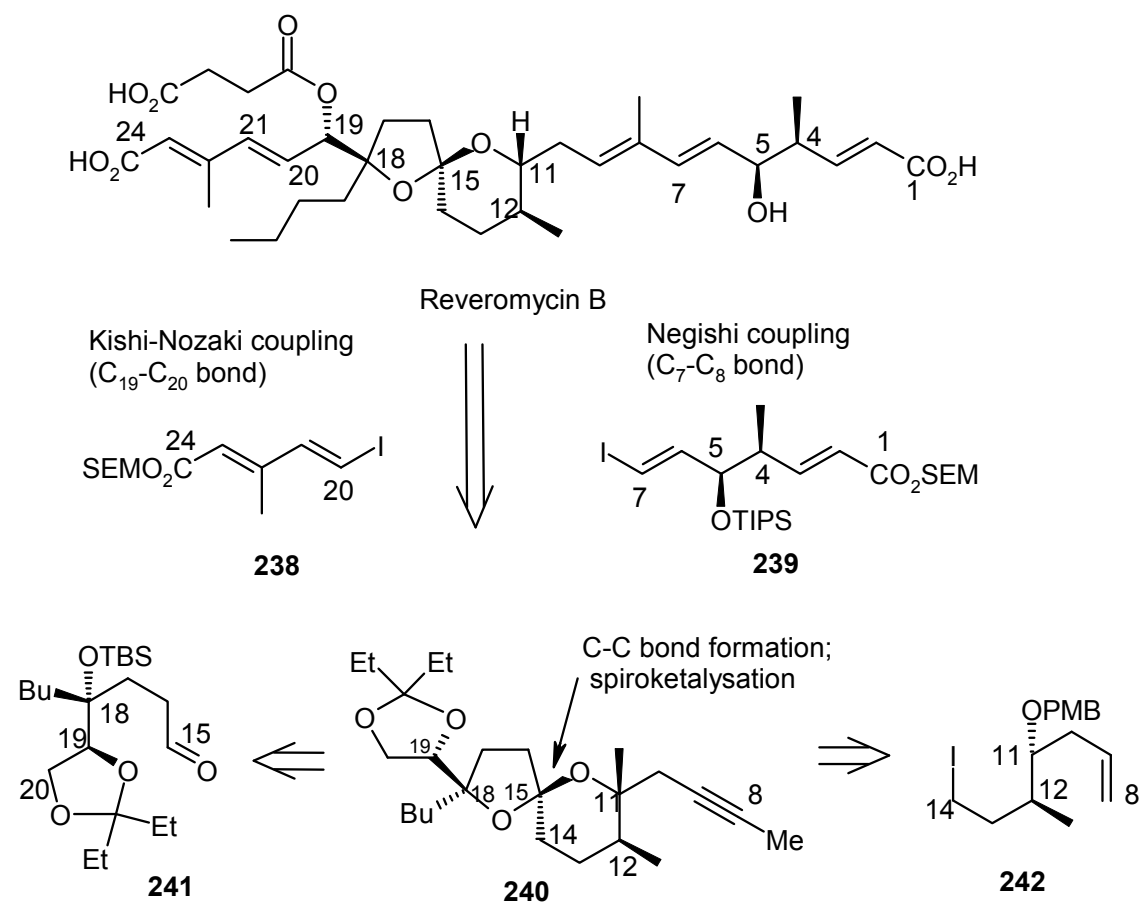

Fragment 240 is prepared from aldehyde 241 and iodide 242. Lithiation of iodide 242 and then addition to aldehyde 241 results alcohol, which in turn is oxidized to ketone 243 . Deprotection of 243 affords spiroketal 244, whose structure was determined from its known triacetate 245 [113]. Compound 244 is then converted to the required alkyne unit $\mathbf{2 4 0}$ by ozonolysis and subsequent CoreyFuchs reaction (Scheme 57) [114]. 
The fragment 239 is prepared from aldehyde 246 using Evan's asymmetric aldol reaction and subsequent transformations (Scheme 58) [115].

Scheme 57. Synthesis of alkyne fragment 240.

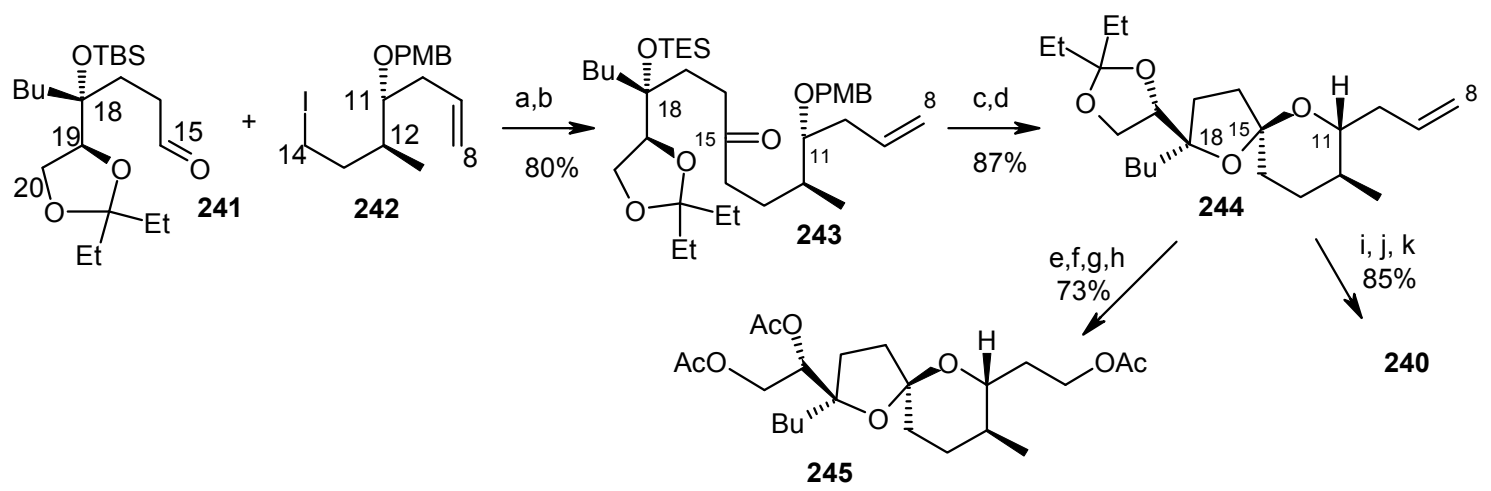

Reagents and conditions: (a) 1.0 equiv. of $\mathbf{2 4 2}, 2.1$ equiv. $t$ - $\mathrm{BuLi},-78{ }^{\circ} \mathrm{C}, \mathrm{Et}_{2} \mathrm{O}, 0.5 \mathrm{~h}$, then 1.4 equiv. of 241, $0.5 \mathrm{~h}, 84 \%$, (b) 1.2 equiv. Dess-Martin periodinane, $\mathrm{CH}_{2} \mathrm{Cl}_{2}, 25{ }^{\circ} \mathrm{C}, 1 \mathrm{~h}, 95 \%$, (c) 1.5 equiv. TBAF.THF, THF, $50{ }^{\circ} \mathrm{C}$, 2h, (d) 1.5 equiv. DDQ, wet $\mathrm{CH}_{2} \mathrm{Cl}_{2}, 15 \mathrm{~min}, 25{ }^{\circ} \mathrm{C}, 87 \%$ (over two steps), (e) 0.1 equiv. CSA, $\mathrm{CH}_{2} \mathrm{Cl}_{2}, 0{ }^{\circ} \mathrm{C}, 3 \mathrm{~h}, 97 \%$, (g) $\mathrm{O}_{3}, \mathrm{CH}_{2} \mathrm{Cl}_{2},-78{ }^{\circ} \mathrm{C}$, then 5.0 equiv. $\mathrm{NaBH}_{4}, \mathrm{MeOH}, 25{ }^{\circ} \mathrm{C}, 1 \mathrm{~h}, 97 \%$, (h) 1.5 equiv. $\mathrm{Ac}_{2} \mathrm{O}, 3$ equiv. $\mathrm{Py}, \mathrm{CH}_{2} \mathrm{Cl}_{2}, 25{ }^{\circ} \mathrm{C}, 15 \mathrm{~min}, 97 \%$, (i) $\mathrm{O}_{3}, \mathrm{CH}_{2} \mathrm{Cl}_{2},-78{ }^{\circ} \mathrm{C}$, then 1.5 equiv. $\mathrm{Ph}_{3} \mathrm{P}$, (j) 5 equiv $\mathrm{CBr}_{4}, 10$ equiv $\mathrm{HMPT}, \mathrm{THF},-30{ }^{\circ} \mathrm{C}, 30 \mathrm{~min}, 89 \%$ (over two steps), (k) 2.1 equiv, BuLi, THF, $-78{ }^{\circ} \mathrm{C}$ to $-20{ }^{\circ} \mathrm{C}, 20 \mathrm{~min}$, then 5 equiv MeI, $-78^{\circ} \mathrm{C}, 2 \mathrm{~h}, 95 \%$.

Scheme 58. Synthesis of iodide fragment 239.
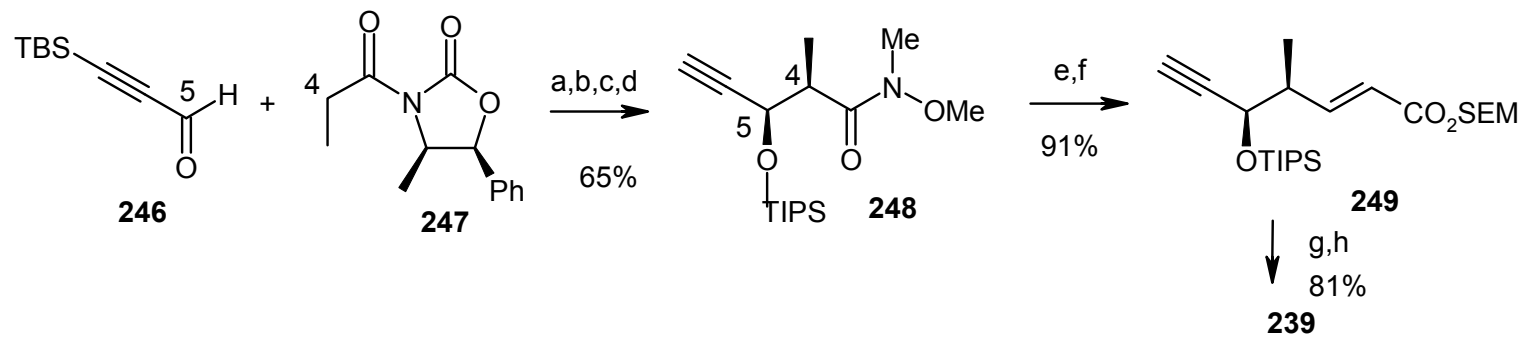

Reagents and conditions: (a) 1.0 equiv 12, 1.0 equiv $\mathrm{Bu}_{2} \mathrm{BOTf}, 1.2$ equiv $\mathrm{Et}_{3} \mathrm{~N}$, then 1.3 equiv 243 , $\mathrm{CH}_{2} \mathrm{Cl}_{2},-78{ }^{\circ} \mathrm{C}, 2 \mathrm{~h}, 80 \%$, (b) 9.0 equiv. $\mathrm{AlMe}_{3}, 9.0$ equiv $\mathrm{MeO}-\mathrm{NHMe} . \mathrm{HCl}, \mathrm{THF},-30$ to $0{ }^{\circ} \mathrm{C}, 2 \mathrm{~h}$, (c) 2.0 equiv. TBAF.SiO 2 , THF, $25{ }^{\circ} \mathrm{C}$, 3h, (d) 1.5 equiv TIPSOTf, 3.0 equiv 2,6-lutidine, $\mathrm{CH}_{2} \mathrm{Cl}_{2}, 25{ }^{\circ} \mathrm{C}, 15 \mathrm{~min}$, $81 \%$ (over 3 steps), (e) 2.5 equiv DIBALH, THF, $-78{ }^{\circ} \mathrm{C}, 0.5 \mathrm{~h}$, (f) 2.5 equiv $\mathrm{Ph}_{3} \mathrm{P}=\mathrm{CH}-\mathrm{CO}_{2} \mathrm{SEM}_{2} \mathrm{CH}_{2} \mathrm{Cl}_{2}, 25$ ${ }^{\circ} \mathrm{C}, 15 \mathrm{~h}, 91 \%$ (over two steps), (g) 0.02 equiv, $\left(\mathrm{Ph}_{3} \mathrm{P}\right){ }_{2} \mathrm{PdCl}_{2}, 1.5$ equiv, $\mathrm{Bu}_{3} \mathrm{SnH}$, benzene, $5{ }^{\circ} \mathrm{C}, 10 \mathrm{~min}$, $91 \%$, (h) $\mathrm{I}_{2}, \mathrm{CH}_{2} \mathrm{Cl}_{2}, 0{ }^{\circ} \mathrm{C}, 5 \mathrm{~min}, 90 \%$.

Next, units 239 and 240 are connected using a modified Negishi coupling to give compound 250 [116,117]. Deprotection followed by oxidative cleavage of $\mathbf{2 5 0}$ affords aldehyde 251, which is connected with iodide 238 using a Kishi-Nozaki coupling to give alcohol 252 [118]. The alcohol 252 is then esterified and finally deprotected to give the target reveromycin B (Scheme 59). 
Scheme 59. Total synthesis of reveromycin $\mathbf{B}$.
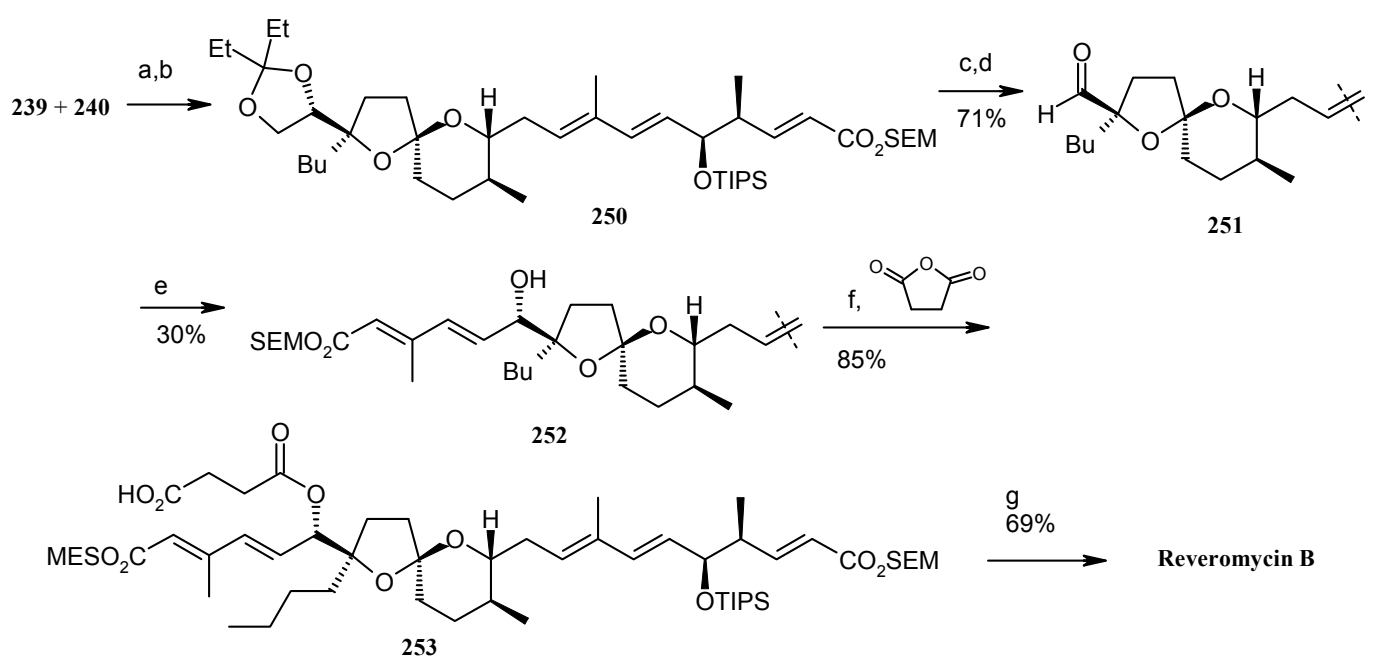

Reagents and conditions: (a) 1.0 equiv $\mathbf{C}, 2.0$ equiv $\mathrm{Cp}_{2} \mathrm{ZrHCl}$, THF, $50{ }^{\circ} \mathrm{C}$, $2 \mathrm{~h}$, (b) 3.0 equiv $\mathrm{ZnCl}_{2}, \mathrm{THF}, 5$ min, $25^{\circ} \mathrm{C}$, then 1.1 equiv 239, 0.05 equiv $\left(\mathrm{Ph}_{3} \mathrm{P}\right)_{4} \mathrm{Pd}$, THF, $2 \mathrm{~h}, 25^{\circ} \mathrm{C}, 84 \%$, (c) 3.0 equiv PPTS, $\mathrm{MeOH}, 3 \mathrm{~h}$, $40{ }^{\circ} \mathrm{C}, 75 \%$, (d) 6.0 equiv $\mathrm{NaIO}_{4}$, THF. $\mathrm{H}_{2} \mathrm{O}(2: 1), 2 \mathrm{~h}, 0{ }^{\circ} \mathrm{C}, 95 \%$, (e) 4.0 equiv 238,24 equiv $\mathrm{CrCl}_{2}$, (with 0.5 equiv $\mathrm{NiCl}_{2}$ ), DMF, $25^{\circ} \mathrm{C}, 3 \mathrm{~h}, 65 \%(1.2: 1$ ratio at $\mathrm{C}-19)$, (f) 10 equiv succinic anhydride, 12 equiv DMAP, $25^{\circ} \mathrm{C}, 3 \mathrm{~h}, 85 \%$, (g) 10 equiv TBAF.THF, THF, $2 \mathrm{~h}, 25^{\circ} \mathrm{C}, 69 \%$.

\subsubsection{Shimizu-Nakata Synthesis}

Shimizu and Nakata have also reported a stereoselective synthesis of reveromycin B [119]. Scheme 60 shows the retrosynthetic analysis of the molecule, which reveals that a one pot Julia olefination between sulfone $\mathbf{2 5 4}$ and aldehyde 255, followed by Wittig reaction, leads to the right part of the polyolefinic side chain. On the other hand, the left part of the molecule can be obtained from HornerWardsworth-Emmons reaction of phosphonate 256, followed by esterification. The spiroketal can be synthesized by coupling reaction between Weinreb amide $\mathbf{2 6 0}$ and alkyne $\mathbf{2 6 1}$.

The Weinreb amide is prepared from known epoxide 262. Epoxide $\mathbf{2 6 2}$ is converted to tetrahydrofuran 263, which on protection and oxidation using $\mathrm{RuCl}_{3}-\mathrm{NaIO}_{4}$ affords lactone 265 (Scheme 61) [120]. Amination of lactone 265 with $\mathrm{Me}_{2} \mathrm{AlCl}-\mathrm{MeNHOMe} \cdot \mathrm{HCl}$ gives Weinreb amide 266, which is converted to desired amide $\mathbf{2 6 0}$ after silylation and acetylation [121]. The alkyne $\mathbf{2 6 1}$ is prepared from known alcohol 268 in four steps as shown in Scheme 62 [113].

The coupling of Weinreb amide $\mathbf{2 6 0}$ and alkyne $\mathbf{2 6 1}$ is effected by $n$-BuLi to give the spiroketal core 259 after hydrogenation (Scheme 63). Selective deprotection of TES, TBS and MTM groups and spiroketalysation affords compound 271, which after deprotection/protection followed by acetylation gives compound 273. Deprotection of silyl group followed by oxidation affords aldehyde 274, which is subjected to Horner-Wadsworth-Emmons reaction with phosphonate 256 to give a mixture of dienoic esters with a ratio of 7:3. Esterification of this mixture with acid 257 provides the desired (20E,22E)275, along with the $20 E, 22 Z$ isomer, with a $14: 1$ ratio.

The component $\mathbf{2 5 5}$ is prepared using an Evans asymmetric aldol reaction, as shown in Scheme 64 [122]. Deprotection of the MPM group in $\mathbf{2 7 5}$ followed by oxidation gives aldehyde $\mathbf{2 8 0}$, which on Wittig reaction and subsequent reduction affords alcohol 282, which is converted to sulfone $\mathbf{2 5 4}$ by 
Mitsunobu reaction followed by oxidation [103]. Julia reaction of 254 with 255 affords $(6 E, 8 E)$-diene 283, which is converted to aldehyde $\mathbf{2 8 4}$ in two steps (Scheme 65). Wittig reaction of $\mathbf{2 8 4}$ affords ester 285, which after removal of TES and allyl protecting groups provide revermycin B [123].

Scheme 60. Retrosynthetic analysis of reveromycin B.

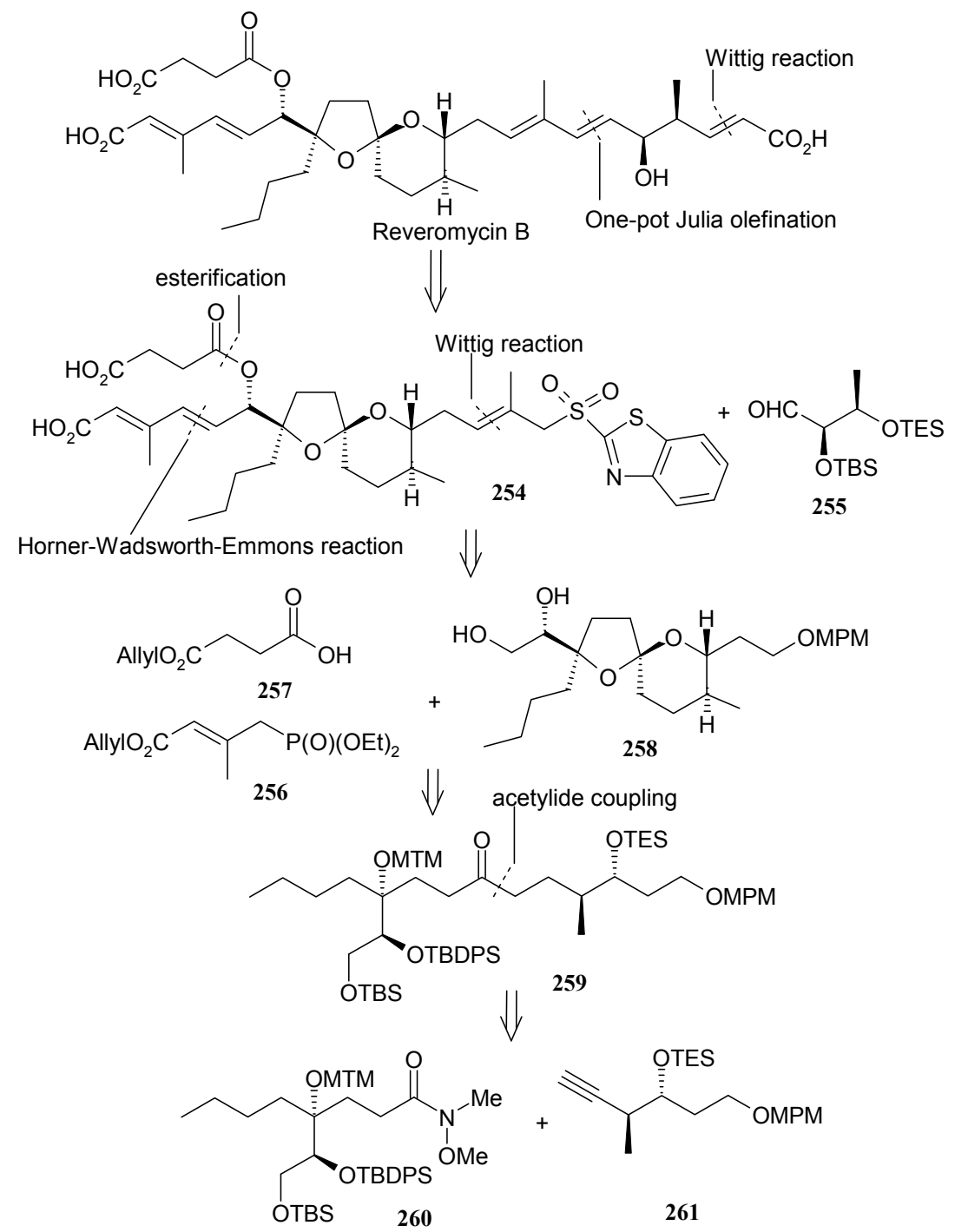

Scheme 61. Synthesis of Weinreb amide 260.

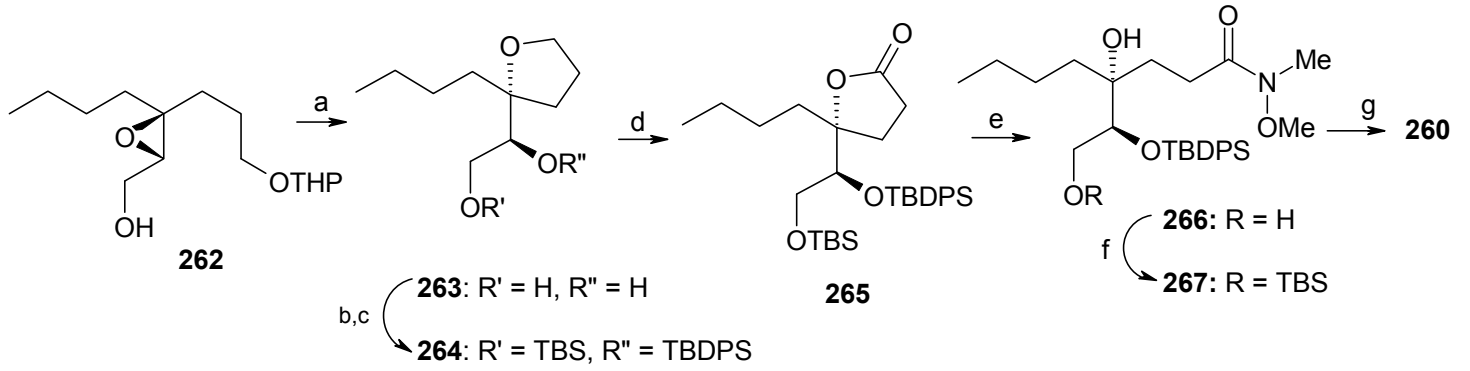

Reagents and conditions: (a) AcOH, THF, $\mathrm{H}_{2} \mathrm{O}$, rt, TsOH, MeOH, rt (88\%), (b) TBSCl, Et $\mathrm{t}_{3} \mathrm{~N}$, DMAP, DMF, $0{ }^{\circ} \mathrm{C}$ to rt, 96\%; (c) TBDPSOTf, lutidine, $\mathrm{CH}_{2} \mathrm{Cl}_{2}, 0{ }^{\circ} \mathrm{C}$ to rt, $95 \%$; (d) $\mathrm{RuCl}_{3}, \mathrm{NaIO}_{4}, \mathrm{CH}_{3} \mathrm{CN}, \mathrm{CCl}_{4}$, phosphate buffer ( $\mathrm{pH} 8$ ), rt, $92 \%$; (e) $\mathrm{Me}_{2} \mathrm{AlCl}$, MeNHOMe. $\mathrm{HCl}, \mathrm{CH}_{2} \mathrm{Cl}_{2}, 0{ }^{\circ} \mathrm{C}$ to rt; (f) $\mathrm{TBSCl}$, imidazole, DMAP, DMF, $0{ }^{\circ} \mathrm{C}$ to rt (65\% 2 steps); (g) DMSO, $\mathrm{Ac}_{2} \mathrm{O}$, rt (94\%). 
Scheme 62. Synthesis of alkyne fragment 261.

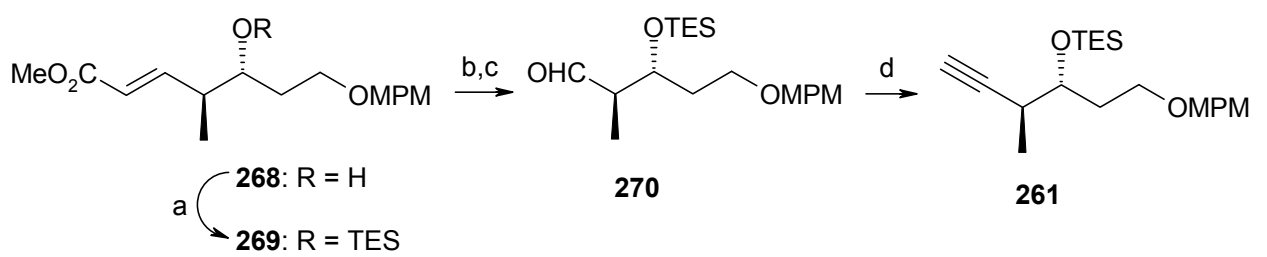

Reagents and conditions: (a) TESCl, imidazole, DMAP, DMF, $0{ }^{\circ} \mathrm{C}$ to rt, $96 \%$; (c) $\mathrm{OsO}_{4}, \mathrm{NMO}, \mathrm{Me}_{2} \mathrm{CO}$, $\mathrm{H}_{2} \mathrm{O}, 97 \%$; (d), TMSCHN $2, n$-BuLi, THF, $-78^{\circ} \mathrm{C}$ to $0{ }^{\circ} \mathrm{C}, 70 \%$.

Scheme 63. Synthesis of spiroketal 275.

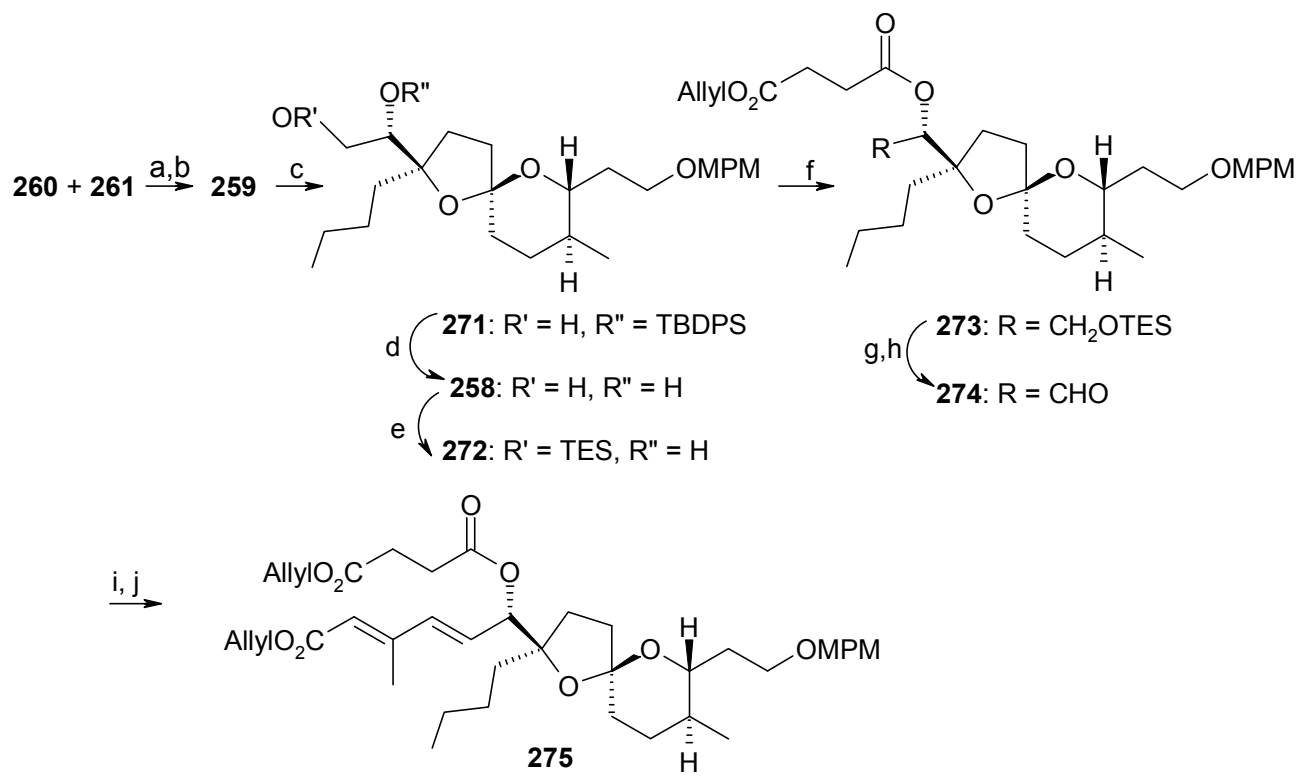

Reagents and conditions: (a) $n$-BuLi, THF, $0{ }^{\circ} \mathrm{C}$, (b) $\mathrm{Pd} / \mathrm{C}, \mathrm{H}_{2}$, EtOAc, rt, $94 \%$, (c) TsOH, $\mathrm{CHCl}_{3}$, EtOH, 0 ${ }^{\circ} \mathrm{C}$ to rt (83\%), (d) TBAF, THF, rt, (86\%), (e) TESCl, $\mathrm{Et}_{3} \mathrm{~N}, \mathrm{CH}_{2} \mathrm{Cl}_{2}, 0{ }^{\circ} \mathrm{C}$, (f) 257, DIC, DMAP, $\mathrm{CH}_{2} \mathrm{Cl}_{2}$, rt, 98\%; (g) PPTS, $\mathrm{CHCl}_{3}, \mathrm{MeOH}, 0{ }^{\circ} \mathrm{C}, 92 \%$; (h) TPAP, NMO, $\mathrm{CH}_{2} \mathrm{Cl}_{2}$, rt, 93\%; (i) 256, LiHMDS, THF, HMPA, $-78^{\circ} \mathrm{C}$ to rt; (j) 257, DIC, DMAP, $\mathrm{CH}_{2} \mathrm{Cl}_{2}$, rt 77\%, 2 steps.

Scheme 64. Synthesis of aldehyde 255.
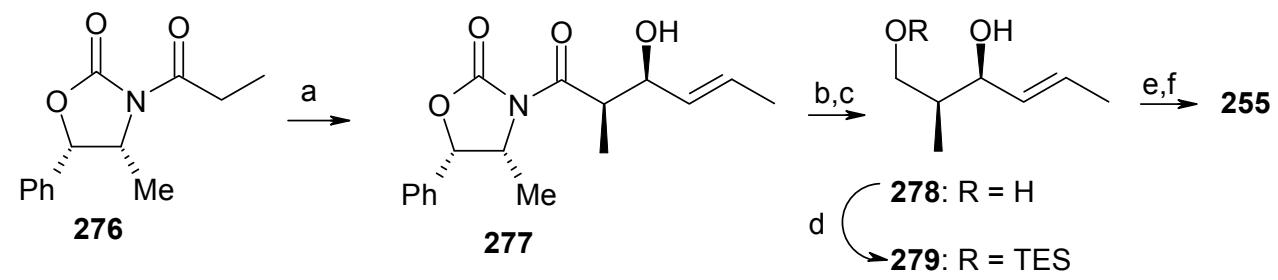

Reagents and conditions: (a) $n$ - $\mathrm{Bu}_{2} \mathrm{BOTf}, i \mathrm{Pr}_{2} \mathrm{NEt}$, crotonaldehyde, $\mathrm{CH}_{2} \mathrm{Cl}_{2},-78{ }^{\circ} \mathrm{C}$ to rt, $86 \%$; (b) TBSOTf, lutidine, $\mathrm{CH}_{2} \mathrm{Cl}_{2}, 0{ }^{\circ} \mathrm{C}, 100 \%$; (c) $\mathrm{NaBH}_{4}$, THF, $\mathrm{H}_{2}, \mathrm{rt}, 87 \%$; (d) TESCl, imidazole, DMF, $0{ }^{\circ} \mathrm{C}$ to rt, $100 \%$; (e) $\mathrm{OsO}_{4}, \mathrm{NMO}, \mathrm{Me}_{2} \mathrm{CO}, \mathrm{H}_{2} \mathrm{O}$, rt, $82 \%$, (f) $\mathrm{Pb}(\mathrm{OAc})_{4}$, toluene, rt, $97 \%$. 
Scheme 65. Total synthesis of reveromycin B.

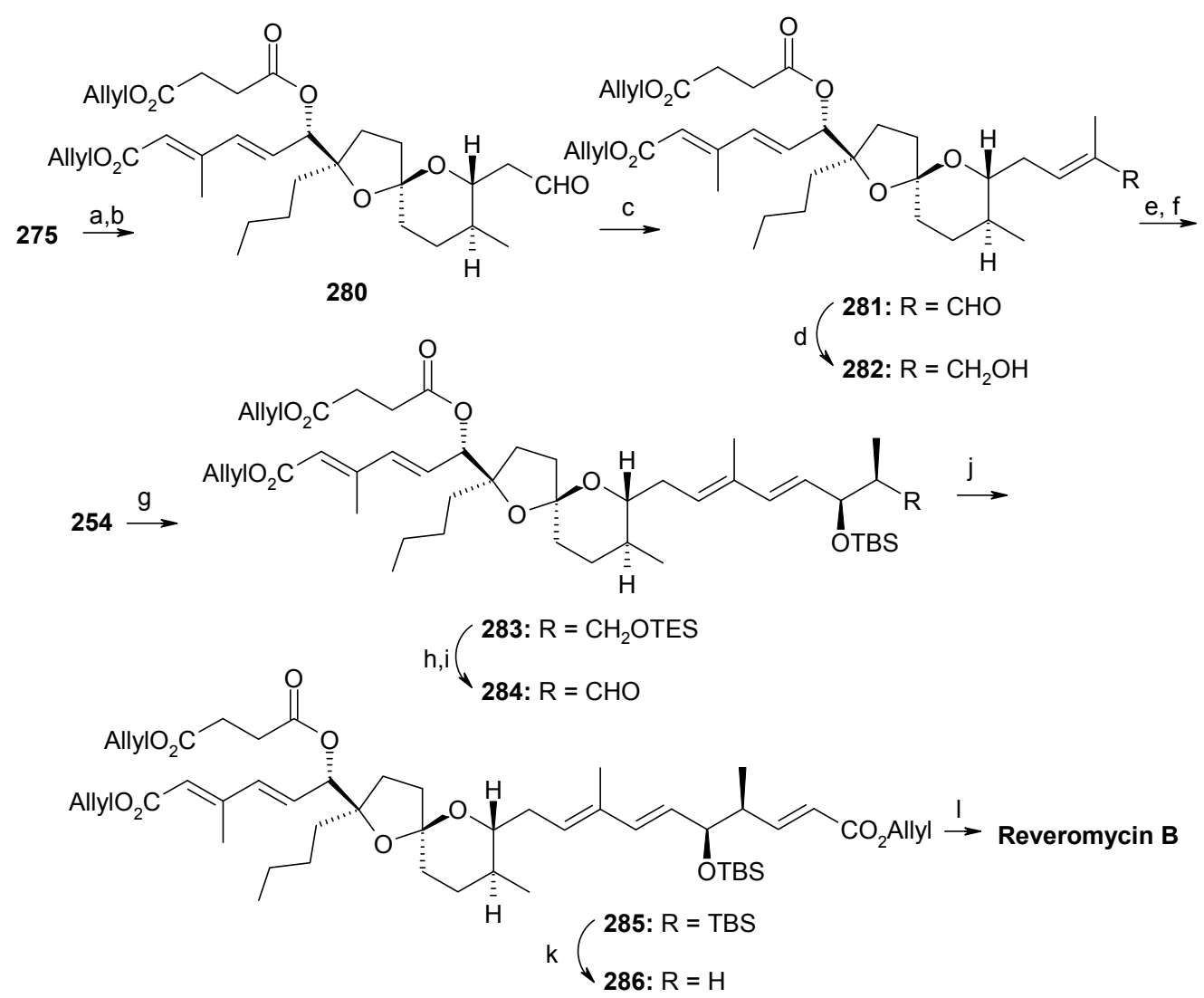

Reagents and conditions: (a) DDQ, $\mathrm{CH}_{2} \mathrm{Cl}_{2}, \mathrm{H}_{2} \mathrm{O}$, rt, $91 \%$; (b) $\mathrm{SO}_{3} \cdot \mathrm{Py}, \mathrm{Et}_{3} \mathrm{~N}, \mathrm{CH}_{2} \mathrm{Cl}_{2}, \mathrm{DMSO}, 0{ }^{\circ} \mathrm{C}$, to rt, 99\%; (c) $\mathrm{Ph}_{3} \mathrm{P}=\mathrm{C}(\mathrm{Me}) \mathrm{CHO}$, toluene, $110{ }^{\circ} \mathrm{C}, 93 \%$, (d) $\mathrm{Zn}\left(\mathrm{BH}_{4}\right)_{2}, \mathrm{Et}_{2} \mathrm{O}, 0{ }^{\circ} \mathrm{C}$; (e) 2-mercaptobenzothiazole, $\mathrm{Ph}_{3} \mathrm{P}$, DEAD, THF, rt; (f) $\mathrm{Mo}_{7} \mathrm{O}_{24}\left(\mathrm{NH}_{4}\right)_{6} \cdot 4 \mathrm{H}_{2} \mathrm{O}, \mathrm{H}_{2} \mathrm{O}_{2}$, EtOH, $0{ }^{\circ} \mathrm{C}$ to rt, 79\%; (g) LiHMDS, 255, THF, -78 ${ }^{\circ} \mathrm{C}$ to $0{ }^{\circ} \mathrm{C}, 56 \%$; (h) PPTS, $\mathrm{CHCl}_{3}, \mathrm{MeOH}, 0{ }^{\circ} \mathrm{C}, 95 \%$; (i) Dess-Martin periodinane, $\mathrm{CH}_{2} \mathrm{Cl}_{2}, \mathrm{rt}, 90 \%$; (j) $\mathrm{Ph}_{3} \mathrm{P}=\mathrm{CHCO}_{2}$ (allyl), toluene, $80{ }^{\circ} \mathrm{C}, 98 \%$; (k) HF.Py, THF, $0{ }^{\circ} \mathrm{C}$, to rt, $78 \%$; (l) $\mathrm{Pd}_{2}(\mathrm{dba})_{3} \cdot \mathrm{CHCl}_{3}, n-\mathrm{Bu}_{3} \mathrm{P}$, $\mathrm{HCO}_{2} \mathrm{H}, \mathrm{Et}_{3} \mathrm{~N}, 1,4-$ dioxane, $50^{\circ} \mathrm{C}, 62 \%$.

Among the three approaches for the synthesis of reveromycin B, the Theodorakis synthesis is the shortest route, consisting of total 21 linear steps and the Shimizo-Nakata synthesis, with 39 steps, the longest one. On the other hand, Rizzacasa completed it in 25 steps. Rizzacasa uses the hetero-DielsAlder reaction, followed by oxidation and subsequent acid-induced ring contraction strategy for construction of the 5,6-spiroketal unit in high yield. Another feature of this synthesis is that only the TBS ether protecting group is used throughout the synthesis. The spiroketal units in the Theodorakis and Shimizu-Nakata syntheses are achieved from spiroketalization of suitably substituted keto alcohols.

\subsection{Total synthesis of (+)-bistramide $C$}

The bistramides were isolated from the marine ascidian Lissoclinum bistratum [124]. Bistramides gained importance due to their attractive biological properties, including antiproliferative effects [125], sodium channel blockage [126], and unique protein kinase $C \delta$ activation [127]. Wipf and coworkers have described the convergent total synthesis of the marine natural product (+)-bistramide C [128]. 
Scheme 66. Retrosynthetic analysis of (+)-bistramide C.

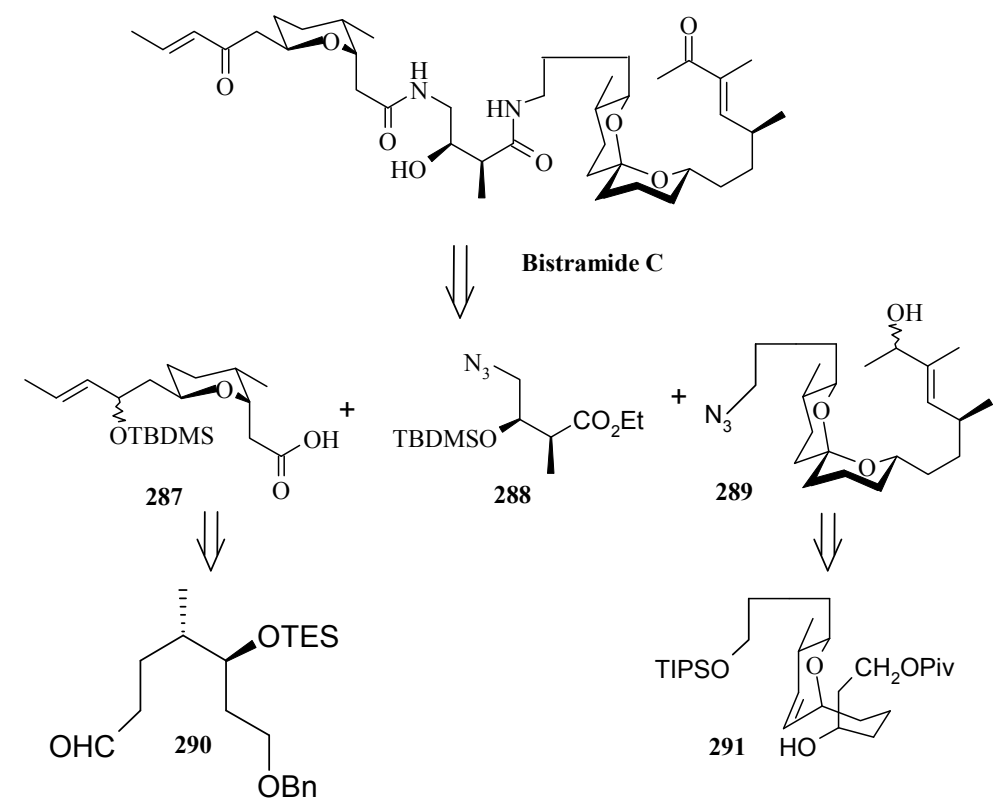

Scheme 67. Synthesis of pyran fragment 287.
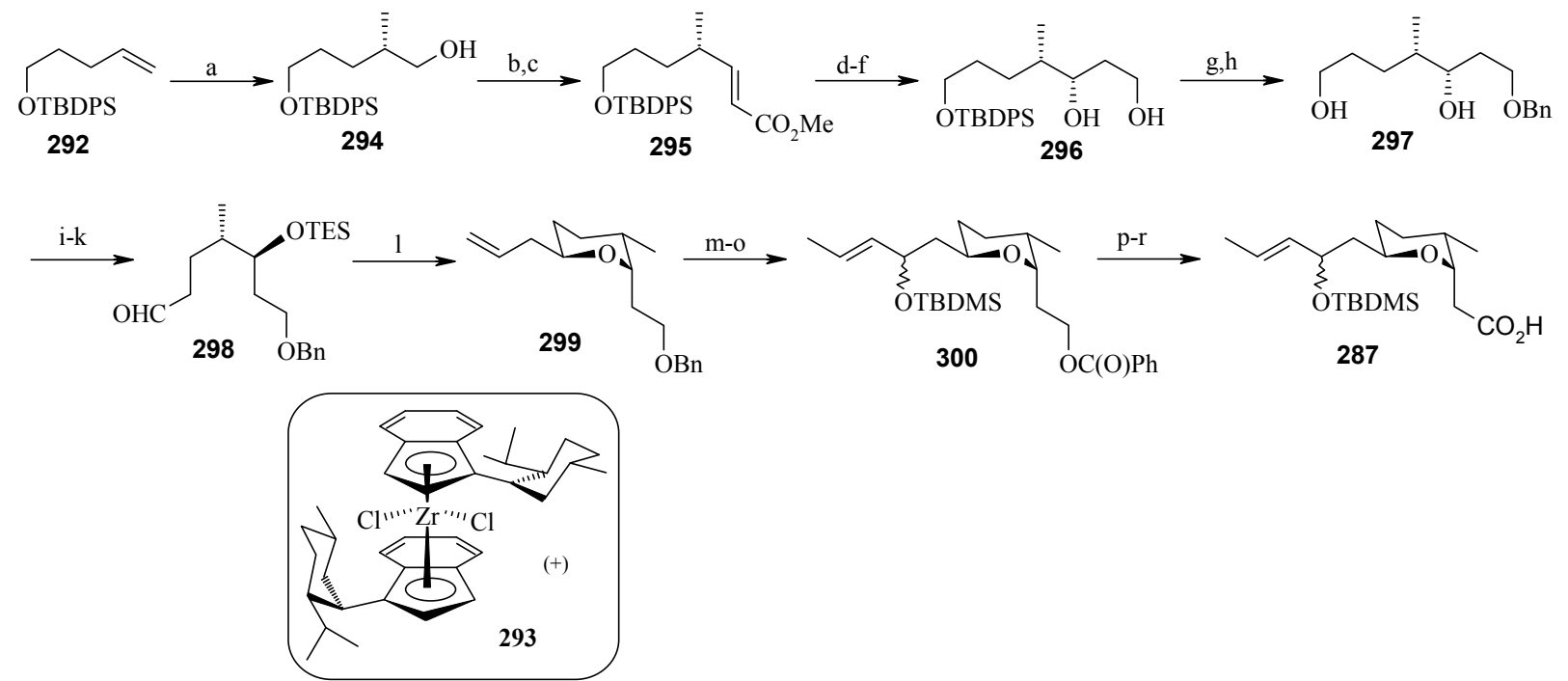

Reagents and conditions: $\mathrm{AlMe}_{3}$ (4.3 equiv.), 293 (2.8 mol\%), $\mathrm{MAO}$ (1.5 equiv), $\mathrm{CH}_{2} \mathrm{Cl}_{2}, 3-5{ }^{\circ} \mathrm{C}, 15 \mathrm{~h}$; then $\mathrm{O}_{2},-20{ }^{\circ} \mathrm{C}$ to rt, $78 \%$; (b) $\mathrm{NaOCl}$, TEMPO, $\mathrm{KBr}, \mathrm{NaHCO}_{3} / \mathrm{Na}_{2} \mathrm{CO}_{3}, \mathrm{CH}_{2} \mathrm{Cl}_{2}, 0{ }^{\circ} \mathrm{C}, 3 \mathrm{~h}, 92 \%$; (c) trimethylphosphonoacetate, DBU, $\mathrm{LiCl}, \mathrm{CH}_{3} \mathrm{CN}, 0{ }^{\circ} \mathrm{C}$ to rt, $6 \mathrm{~h}, 91 \%$; (d) DIBALH, $\mathrm{CH}_{2} \mathrm{Cl}_{2},-78{ }^{\circ} \mathrm{C}, 2 \mathrm{~h}, 98 \%$; (e) TBHP, D-(-)-DIPT, Ti(O-iPr $)_{4}, 4 \AA \mathrm{MS}, \mathrm{CH}_{2} \mathrm{Cl}_{2},-20{ }^{\circ} \mathrm{C}, 15 \mathrm{~h}, 96 \%$; (f) Red-Al, toluene, $-78{ }^{\circ} \mathrm{C}$ to rt, $13 \mathrm{~h}$, quant.; (g) NaH, THF, $0{ }^{\circ} \mathrm{C}$ to rt, $15 \mathrm{~h}, 98 \%$; (h) TBAF, THF, $0{ }^{\circ} \mathrm{C}$ to rt, $15 \mathrm{~h}, 98 \%$; (i) TES-OTf, 2,6-lutidine, $\mathrm{CH}_{2} \mathrm{Cl}_{2}, 0{ }^{\circ} \mathrm{C}, 30$ min, quant; (j) $\mathrm{H}_{2} \mathrm{O}$, AcOH, THF (1:3:10), $0{ }^{\circ} \mathrm{C}$ to rt, 4h, 79\%; (k) Dess-Martin periodinane, $\mathrm{NaHCO}_{3}, \mathrm{CH}_{2} \mathrm{Cl}_{2}, 0{ }^{\circ} \mathrm{C}$ to rt, $2 \mathrm{~h}, 81 \%$; (l) allyl-TMS, $\mathrm{BiBr}_{3}$ (cat), $\mathrm{CH}_{3} \mathrm{CN}$, rt, 23h, $72 \%$; (m) $\mathrm{O}_{3} / \mathrm{O}_{2}$, methyl pyruvate, $\mathrm{CH}_{2} \mathrm{Cl}_{2},-78{ }^{\circ} \mathrm{C}, 30 \mathrm{~min}$; then $\mathrm{PPh}_{3},-78{ }^{\circ} \mathrm{C}$ to rt, $16 \mathrm{~h}, 60-65 \%$; (n) trans-2-propenyl bromide, $t$ - $\mathrm{BuLi}, \mathrm{Et}_{2} \mathrm{O},-78{ }^{\circ} \mathrm{C}(45 \mathrm{~min})$ to $0{ }^{\circ} \mathrm{C}$ to $-78{ }^{\circ} \mathrm{C}$ then addition to $100{ }^{\circ} \mathrm{C}$ solution of aldehyde in $\mathrm{Et}_{2} \mathrm{O}$; (o) TBDMS-Cl, imidazole, $\mathrm{CH}_{2} \mathrm{Cl}_{2}, 0{ }^{\circ} \mathrm{C}$ to rt, $21 \mathrm{~h}, 82 \%$; (p) $\mathrm{NaOMe}, \mathrm{MeOH} / \mathrm{THF}, 0{ }^{\circ} \mathrm{C}$ to rt, $24 \mathrm{~h}$, 90\%; (q) Dess-Martin periodinane, $\mathrm{NaHCO}_{3}, \mathrm{CH}_{2} \mathrm{Cl}_{2}, 0{ }^{\circ} \mathrm{C}$, to rt, 1h; (r) $\mathrm{NaH}_{2} \mathrm{PO}_{4} \cdot \mathrm{H}_{2} \mathrm{O}, 2$-methyl-2-butene, $t$-BuOH, rt. $1 \mathrm{~h}, 67 \%$. 
The retrosynthetic analysis of the molecule is shown in Scheme 66. The basic units of the molecules are 287, 288 and 289. Azide coupling connects all three units. The pyran is prepared from aldehyde 290, whereas the spiroketal is synthesized from alcohol 291. Fragment 287 is prepared starting from 292 (Scheme 67) [129]. Erker's chiral zirconocene 293 is used to synthesize the $\beta$-methylated alcohol 294 with $83 \%$ ee. Oxidation followed by a Horner-Wadsworth-Emmons reaction provides enoate 295, which after reduction to alcohol is subjected to Sharpless asymmetric epoxidation. The resulting epoxy alcohol is converted to diol 296, of which the primary alcohol is selectively protected as a benzyl ether and then desilylated to give 297. Compound 297 is then converted to aldehyde 298 after protection/deprotection and oxidation sequences. Aldehyde 298 is converted to trans-2,6-substituted tetrahydropyran 299 with a $>5: 1$ diastereomeric ratio using Evans' methodology [130]. Oxidation of 299 with ozone, followed by in situ reduction with $\mathrm{Ph}_{3} \mathrm{P}$ transforms the benzyl ether into the benzoate ester and the allyl group into the aldehyde, which upon treatment with propenyl lithium provides the secondary allylic alcohol as a $>10: 1$ mixture of epimers. The allylic alcohol is then converted to the requisite carboxylic acid fragment $\mathbf{2 8 7}$ after protection/deprotection and two-step oxidation sequence.

Scheme 68. Synthesis of spiroketal fragment 289.
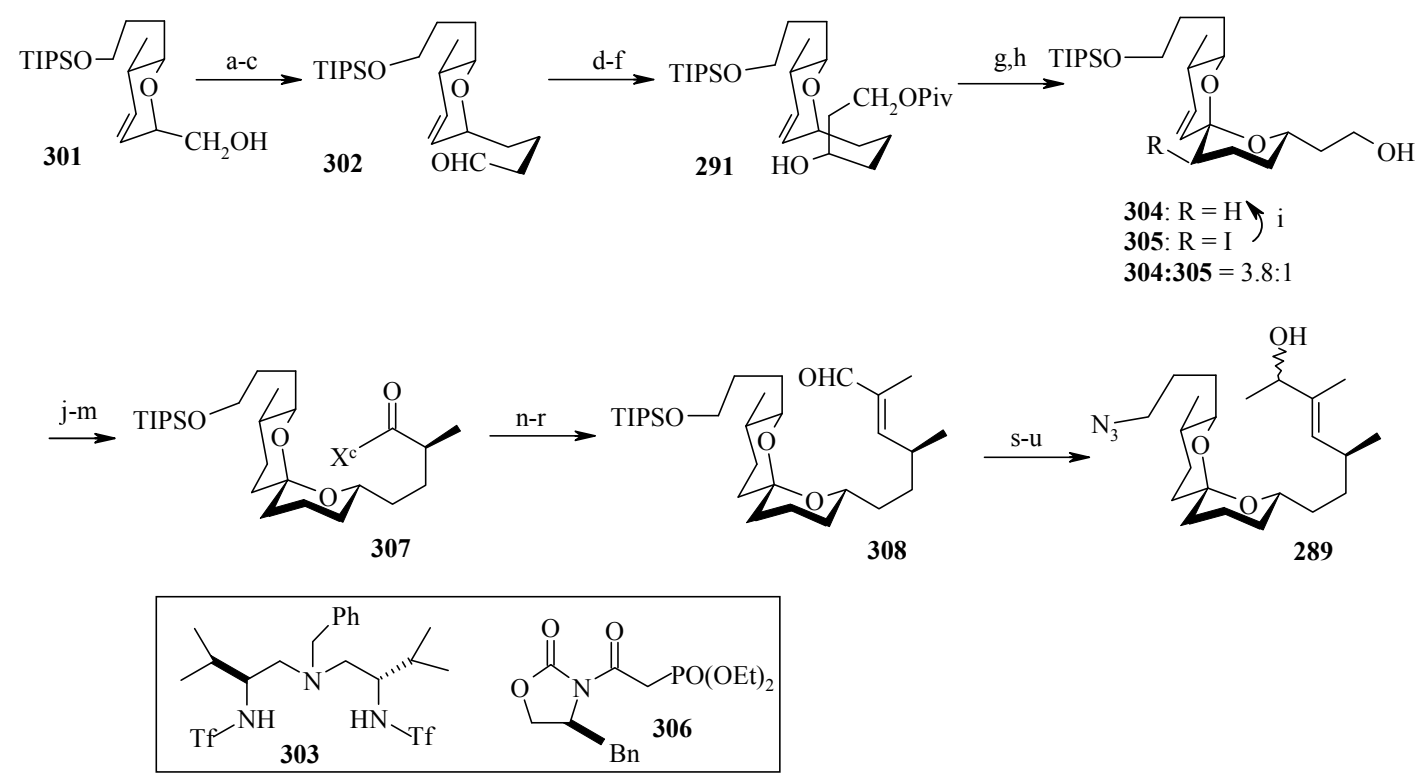

Reagents and conditions: (a) $\mathrm{Tf}_{2} \mathrm{O}$, pyridine, $\mathrm{CH}_{2} \mathrm{Cl}_{2},-45{ }^{\circ} \mathrm{C}$ to $0{ }^{\circ} \mathrm{C}, 45 \mathrm{~min}$; then $\left(\mathrm{CH}_{2} \mathrm{CHCH}_{2}\right)_{2} \mathrm{CuCNLi}_{2}$ (1.5 equiv), THF, -78 to $-60{ }^{\circ} \mathrm{C}$, $4 \mathrm{~h}, 79 \%$; (b) 9-BBN, THF, $0{ }^{\circ} \mathrm{C}$ to rt, $14 \mathrm{~h}$; then $0.5 \mathrm{M} \mathrm{NaOH}, 30 \% \mathrm{H}_{2} \mathrm{O}_{2}, 0$ ${ }^{\circ} \mathrm{C}$ to rt, $65 \%$; (c) Dess-Martin periodinane, $\mathrm{CH}_{2} \mathrm{Cl}_{2}, 0{ }^{\circ} \mathrm{C}$ to rt, $1 \mathrm{~h}, 77 \%$; (d) 303 (30 mol\%), $\mathrm{AlMe}_{3}$, acetyl bromide, $(i \mathrm{Pr})_{2} \mathrm{NEt}, \mathrm{CH}_{2} \mathrm{Cl}_{2},-50{ }^{\circ} \mathrm{C}, 20 \mathrm{~h}$; (e) $\mathrm{LAH}, \mathrm{Et}_{2} \mathrm{O}, 0{ }^{\circ} \mathrm{C}$ to rt, $75 \mathrm{~min}, 88 \%$; (f) pivaloyl chloride, Py, rt, 24h, 83\%; (g) $\mathrm{PhI}(\mathrm{OAc})_{2}, \mathrm{I}_{2}, \mathrm{CCl}_{4}$, hv, rt, 2h; (h) LAH, $\mathrm{Et}_{2} \mathrm{O}, 0{ }^{\circ} \mathrm{C}$ to rt, $26 \%$; (i) $(n-\mathrm{Bu})_{3} \mathrm{SnH}, \mathrm{AIBN}, 80{ }^{\circ} \mathrm{C}$, 14h, 94\%; (j) PCC, NaOAc, $\mathrm{CH}_{2} \mathrm{Cl}_{2}$, rt, 1.5h, 84\%; (k) 174, (iPr) ${ }_{2} \mathrm{NEt}$, LiCl, THF, $12 \mathrm{~h}, 87 \%$; (l) Pt/C, $\mathrm{H}_{2}$, $\mathrm{MeOH}$, rt, 1.5h, 79\%; (m) NaHMDS, MeI, THF, $-78^{\circ} \mathrm{C}, 4.5 \mathrm{~h}, 67 \%$; (n) $\mathrm{LiBH}_{4}, \mathrm{EtOH}, \mathrm{Et}_{2} \mathrm{O},-25^{\circ} \mathrm{C}$ to $0{ }^{\circ} \mathrm{C}$ (2.5h) to $5{ }^{\circ} \mathrm{C}$, (12h), 77\%; (o) Dess-Martin periodinane, $\mathrm{CH}_{2} \mathrm{Cl}_{2}, \mathrm{rt}, 25 \mathrm{~min}, 77 \%$; (p) $\mathrm{EtO}_{2} \mathrm{CC}(\mathrm{Me})=\mathrm{PPh}_{3}$, toluene (degassed), rt, 10d; (q) LAH, THF, $0{ }^{\circ} \mathrm{C}$ to rt., $2 \mathrm{~h}, 68 \%$; (r) Dess-Martin periopdinane, $0{ }^{\circ} \mathrm{C}$ to $\mathrm{rt}, 70$ min, $93 \%$, (s) $\mathrm{MeMgBr}, \mathrm{Et}_{2} \mathrm{O}, 0{ }^{\circ} \mathrm{C}, 93 \%$; (t) TBAF, THF, $0{ }^{\circ} \mathrm{C}$ to rt, $18 \mathrm{~h}$, quant.; (u) $\mathrm{Ms}_{2} \mathrm{O},(i \operatorname{Pr})_{2} \mathrm{NEt}$, $\mathrm{CH}_{2} \mathrm{Cl}_{2}, 0{ }^{\circ} \mathrm{C}$ to rt, $1 \mathrm{~h}$, then $\mathrm{NaN}_{3}$, DMF, $70{ }^{\circ} \mathrm{C}, 48 \mathrm{~h}, 49 \%$. 
The spiroketal fragment $\mathbf{2 8 9}$ is prepared from the D-glucal derivative $\mathbf{3 0 1}$ [131], which is converted to the primary triflate and then chain extended by allyl cuprate (Scheme 68) [132]. The terminal olefin of the resulting compound is converted to the key aldehyde intermediate $\mathbf{3 0 2}$ by selective hydroboration followed by Dess-Martin oxidation. The $(S)$-configured stereocenter at the bistramide C-31 is installed by Nelson's acyl halide-aldehyde condensation method [133]. Thus, the condensation of acetyl bromide and $\mathbf{3 0 2}$ under this condition affords $\beta$-lactone with excellent diastereoselectivity ( $>95 \%$ de), which is converted to spiroketal precursor 291 after reduction and pivaloylation of primary alcohol.

The precursor $\mathbf{2 9 1}$ is then oxidatively cyclised in the presence of iodobenzenediacetate and iodine to give a mixture of partially iodinated spiroketals $\mathbf{3 0 4}$ and $\mathbf{3 0 5}$ upon irradiation with a $250 \mathrm{~W}$ tungsten lamp [134]. Reductive removal of the pivaloate and oxidation of the primary alcohol to the aldehyde, the $\alpha, \beta$-unsaturated oxazolidinone is obtained via a Horner-Wadsworth-Emmons reaction with phosphonate 306 [135]. Catalytic hydrogenation of both alkenes with $\mathrm{Pt} / \mathrm{C}$ followed by Evans methylation gives $\mathbf{3 0 7}$ [115]. Reductive removal of the chiral auxiliary in $\mathbf{3 0 7}$ followed by oxidation of the intermediate alcohol leads to the aldehyde, which upon Wittig reaction, followed by reduction of the resultant enoate with lithium aluminium hydride and oxidation of the allylic alcohol affords 308 . Finally, the key azide fragment $\mathbf{2 8 9}$ is obtained by Grignard reaction, deprotection of silyl group, and selective mesylation of the $1^{\circ}$ alcohol followed by an $\mathrm{S}_{\mathrm{N}} 2$-displacement of the crude mesylate with sodium azide.

Scheme 69. Total synthesis of (+)-bistramide C.

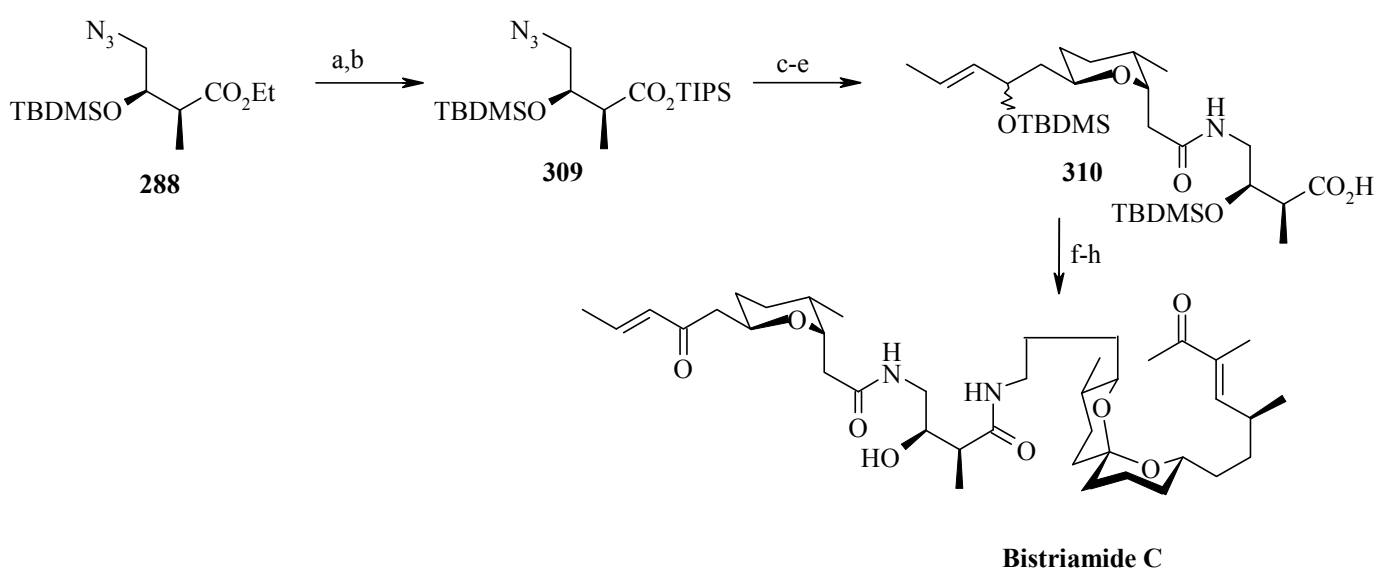

Reagents and conditions: (a) LiOH.H ${ }_{2} \mathrm{O}$, EtOH, $0{ }^{\circ} \mathrm{C}$ to rt, $15 \mathrm{~h}$; (b) TIPS-Cl, NEt ${ }_{3}$. THF/DMF (1:1), $0{ }^{\circ} \mathrm{C}, 30$ min, 82\%; (c) $\mathrm{H}_{2}$ (1 atm), Pd/C, THF, rt, 3.5h; (d) 287, PyBOP, Et $\mathrm{E}_{3} \mathrm{~N}, \mathrm{CH}_{2} \mathrm{Cl}_{2}, \mathrm{rt}, 16 \mathrm{~h}$; (e) TBAF, (0.1 M), THF, $0{ }^{\circ} \mathrm{C}, 25 \mathrm{~min}, 86 \%$; (f) 289, $\mathrm{Ph}_{3} \mathrm{P}$ (1.0 Mol in THF), $\mathrm{H}_{2} \mathrm{O}$, THF (degassed), rt, 41h, then 180, PyBOP, ( $i \mathrm{Pr})_{2} \mathrm{NEt}$, DMF, rt, 47h, 58\%; (g) PPTS, MeOH, rt; 48h; (h) Dess-Martin periodinane (15wt $\%$ in $\left.\mathrm{CH}_{2} \mathrm{Cl}_{2}\right)$, $\mathrm{CH}_{2} \mathrm{Cl}_{2}, 0{ }^{\circ} \mathrm{C}$ to rt, $1 \mathrm{~h}, 77 \%$.

The $\gamma$-amino carboxylate 288, obtained from D-malic acid, is converted to azide $\mathbf{3 0 9}$ via saponification of the ethyl ester and temporary re-protection of the resultant carboxylic acid as the TIPS ester in two-steps. The azide $\mathbf{3 0 9}$ is reduced to amine and then condensed with acid $\mathbf{2 8 7}$ to give the desired C-13 amide, which is then deprotected to give carboxylic acid 310. The spiroketal azide 289 is converted to amine and the crude amine is treated with 310, followed by PyBOP and Hunig's 
base. Finally, global deprotection under mildly acidic conditions followed by selective oxidation of the two allylic alcohols provides (+)-bistramide C (Scheme 69).

\subsection{Total synthesis of Attenol A}

Novel bicyclic triols, attenols A and B, were isolated from the Chinese bivalve Pinna attenuata [136]. These attenols exhibited moderate cytotoxicity against P388 cells. Attenol A differs from the attenol $\mathrm{B}$ in that the former contains a $[5,4]$ spiroketal moiety and the later contains a dioxabicyclo[3.2.1] octane unit. Attenols are highly functionalized, asymmetric molecules, and their preparation poses interesting challenges to synthetic organic chemists.

\subsubsection{Weghe and Eustache Synthesis}

Weghe et al. have reported a synthesis of attenol A using silicon tethered coupling metathesis [137]. The retrosynthetic analysis of the attenol A shows that the spiroketal moiety 311 can be obtained from ketone diol 312, which in turn can be accessed from silicon tethered ring-closing metathesis of fragments 314 and 316. Fragment 314 is prepared from (tert-butyl-diphenylsiloloxy)acetaldehyde 315 [138]. On the other hand the fragment 316 is prepared from known diepoxide 319 via C2-symmetric diol 318 (Scheme 70) [139].

Thus, reaction of allylmagnesium bromide/cuprous iodide with diepoxide 319 affords the diol $\mathbf{3 1 8}$, which is converted to monoprotected alcohol 321. In this stage one of the olefin should be protected while other should be subjected to allylic oxidation to provide anchor for the silicon tether. The free alcohol and olefin are protected by converting them to cyclic ether 322a and 322b [140]. Selenium dioxide oxidation of 322a,b affords the allylic alcohols 323a,b (Scheme 71).

Scheme 70. Retrosynthetic analysis of attenol A.

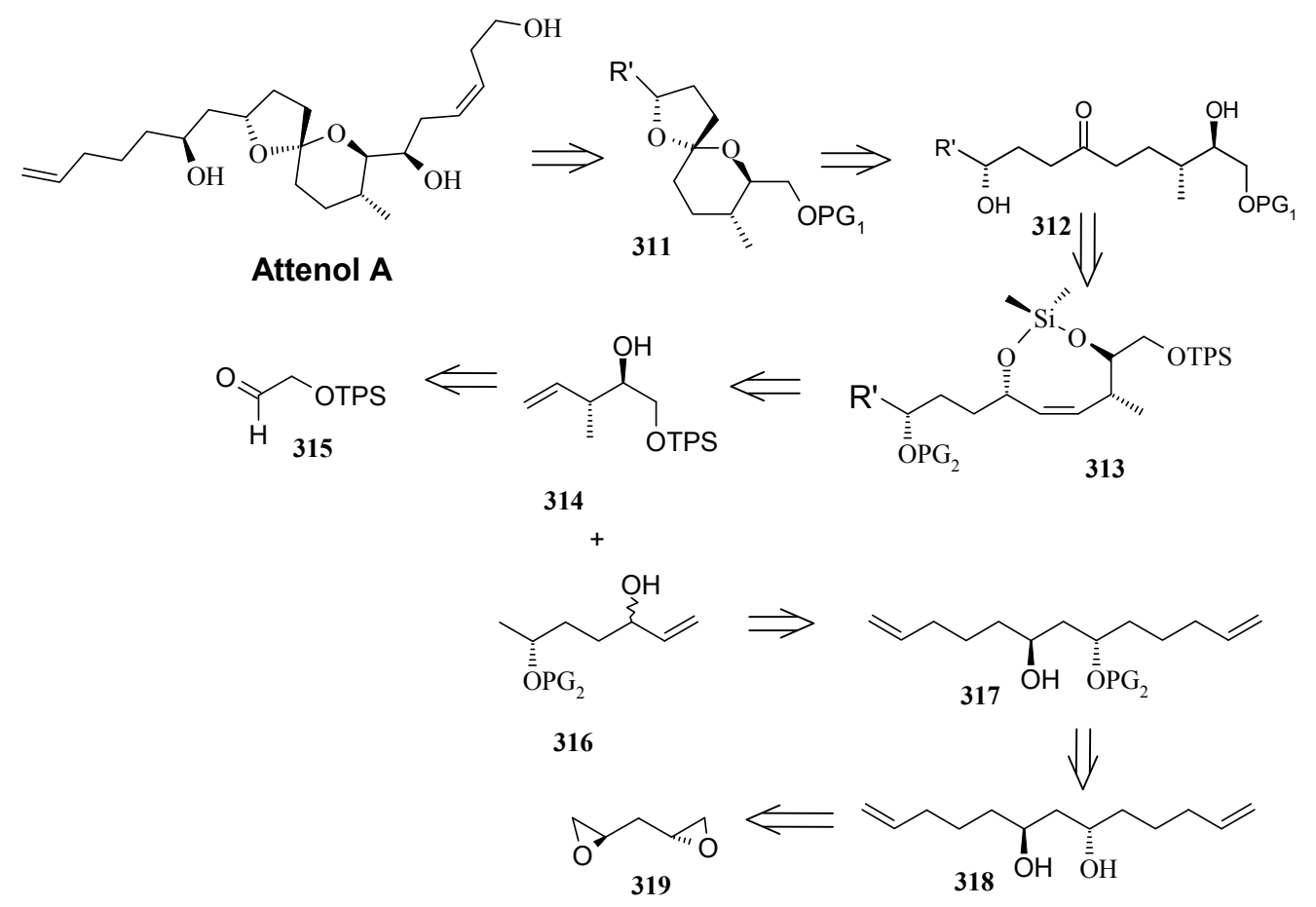


Scheme 71. Synthesis of allylic alcohols 323a, $\mathbf{b}$ from diepoxide 319.<smiles>C=CCCCC1CC(CCCC=CC)OC(C(N)=O)O1</smiles>

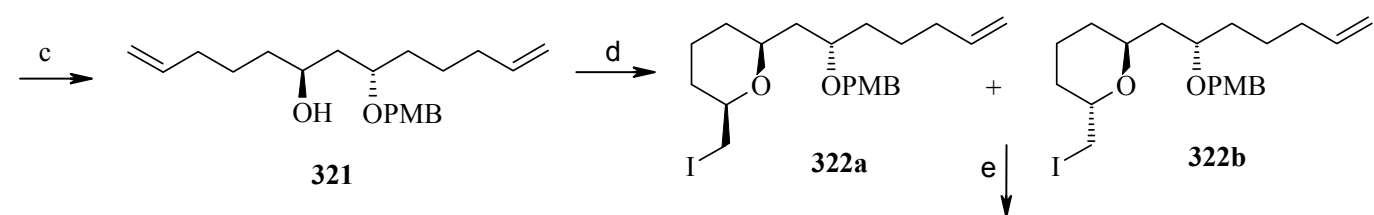

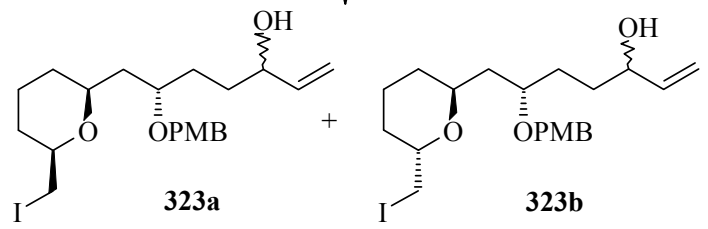

Reagents and conditions: (a) $\mathrm{CH}_{2}=\mathrm{CHCH}_{2} \mathrm{CH}_{2} \mathrm{MgBr} / \mathrm{CuI}$, THF, $-40{ }^{\circ} \mathrm{C}, 3.5 \mathrm{~h}, 88 \%$; (b) $\mathrm{PMPCH}(\mathrm{OMe})_{2}$, CSA (cat), $\mathrm{CH}_{2} \mathrm{Cl}_{2}, 16 \mathrm{~h}, 20{ }^{\circ} \mathrm{C}, 88 \%$; (c) $\mathrm{NaBH}_{3} \mathrm{CN}, \mathrm{CF}_{3} \mathrm{COOH}$, DMF, $0{ }^{\circ} \mathrm{C}, 10 \mathrm{~h}, 76 \%$; (d) $\mathrm{NIS}, \mathrm{K}_{2} \mathrm{CO}_{3}$, $\mathrm{CH}_{2} \mathrm{Cl}_{2}, 20{ }^{\circ} \mathrm{C}, 80 \%$; (e) $\mathrm{SeO}_{2} / \mathrm{TBHP} . \mathrm{CH}_{2} \mathrm{Cl}_{2}, 20^{\circ} \mathrm{C}, 12$ days, $68 \%$.

Scheme 72. Synthesis of spiroketal 327 from fragment 314.

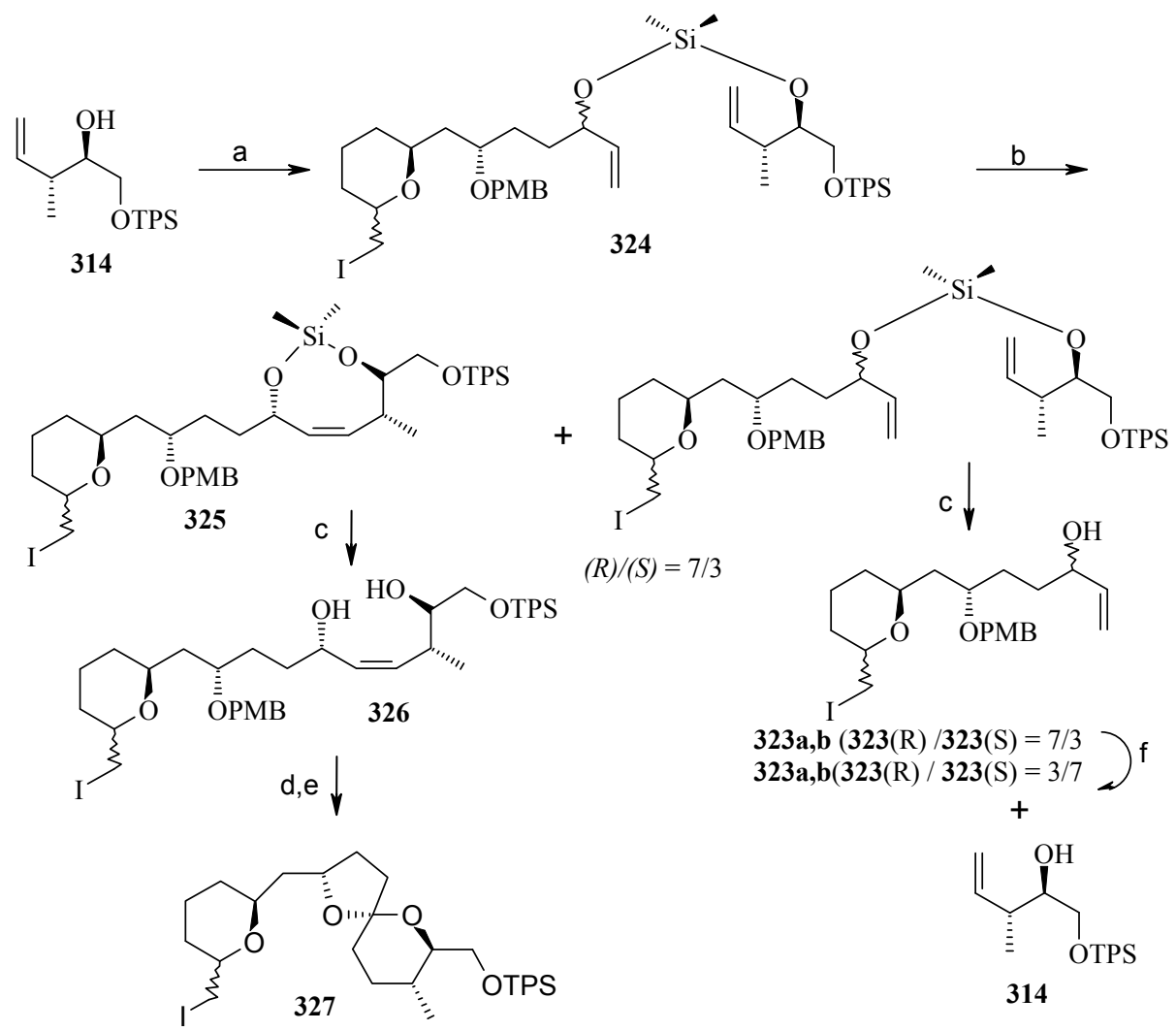

Reagents and conditions: (a) (i) BuLi, THF, $-78{ }^{\circ} \mathrm{C}, 10 \mathrm{~min}$, then $\mathrm{Me}_{2} \mathrm{SiCl}_{2}$ (excess), 78 to $20{ }^{\circ} \mathrm{C}, 1 \mathrm{~h}$; (ii) 323a,b, imidazole, THF, $20{ }^{\circ} \mathrm{C}, 16 \mathrm{~h}, 92 \%$; (b) [Mo], benzene, $20^{\circ} \mathrm{C}, 24 \mathrm{~h}$; (c) TFA, THF, MeOH, $20{ }^{\circ} \mathrm{C}, 24 \mathrm{~h}$, 22\% (326, 2 steps), 30\% (323, 2steps), 45\% (323, 2 steps); (d) $\mathrm{MnO}_{2}$ (30 equiv), EtOAc, rt, 24h; (e) (i) $\mathrm{H}_{2}$, $\mathrm{Pd} / \mathrm{C}$, EtOAc, rt, 4h, (ii) DDQ, $\mathrm{CH}_{2} \mathrm{Cl}_{2}, \mathrm{H}_{2} \mathrm{O}, 20{ }^{\circ} \mathrm{C}, 30 \mathrm{~min}, 72 \%$ (3 steps); (f) (i) $p-\mathrm{NO}_{2} \mathrm{BzCOOH}, \mathrm{Ph}_{3} \mathrm{P}$, DEAD, $-20{ }^{\circ} \mathrm{C}, 2 \mathrm{~h}$, (ii) $\mathrm{NaOH}, \mathrm{EtOH}, 0{ }^{\circ} \mathrm{C}$ to $20^{\circ} \mathrm{C}, 2 \mathrm{~h}, 80 \%$ (2 steps). 
Reaction of dichlorodimethylsilane with fragments 314 and 323a,b affords the silylketal 324, which is subjected to ring closing metathesis reaction using the molybdenum complex A as catalyst.

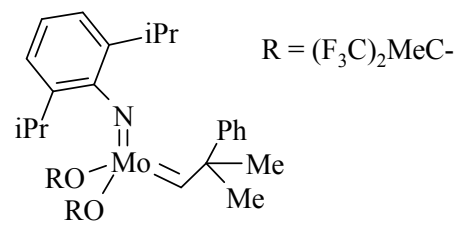

[A]

Two isomers with $(S)$-configuration at C-11 are formed out of four possible isomers along with some starting material. The unreacted silyl ether is cleaved to provide $\mathbf{3 1 4}$ and 323a,b that are recirculated to increase the yield (Scheme 72). Cleavage of the silyl group followed by oxidation of allylic alcohol, reduction of the conjugated double bond and removal of the PMB protecting group affords the ketal 327. Ketal 327 is converted to aldehyde $\mathbf{3 2 9}$ in two steps and then condensed with stannyl derivative of (E)-5-(4-methoxybenzyloxy)-pent-2-en-1-ol to give $\mathbf{3 3 0}$ as a 6:4 mixture, which was separated by chromatography. Regenerating the terminal olefin and C-OH-6 by treatment with butyllithium and the deprotection of PMB group affords attenol A (Scheme 73).

Scheme 73. Total synthesis of attenol A.
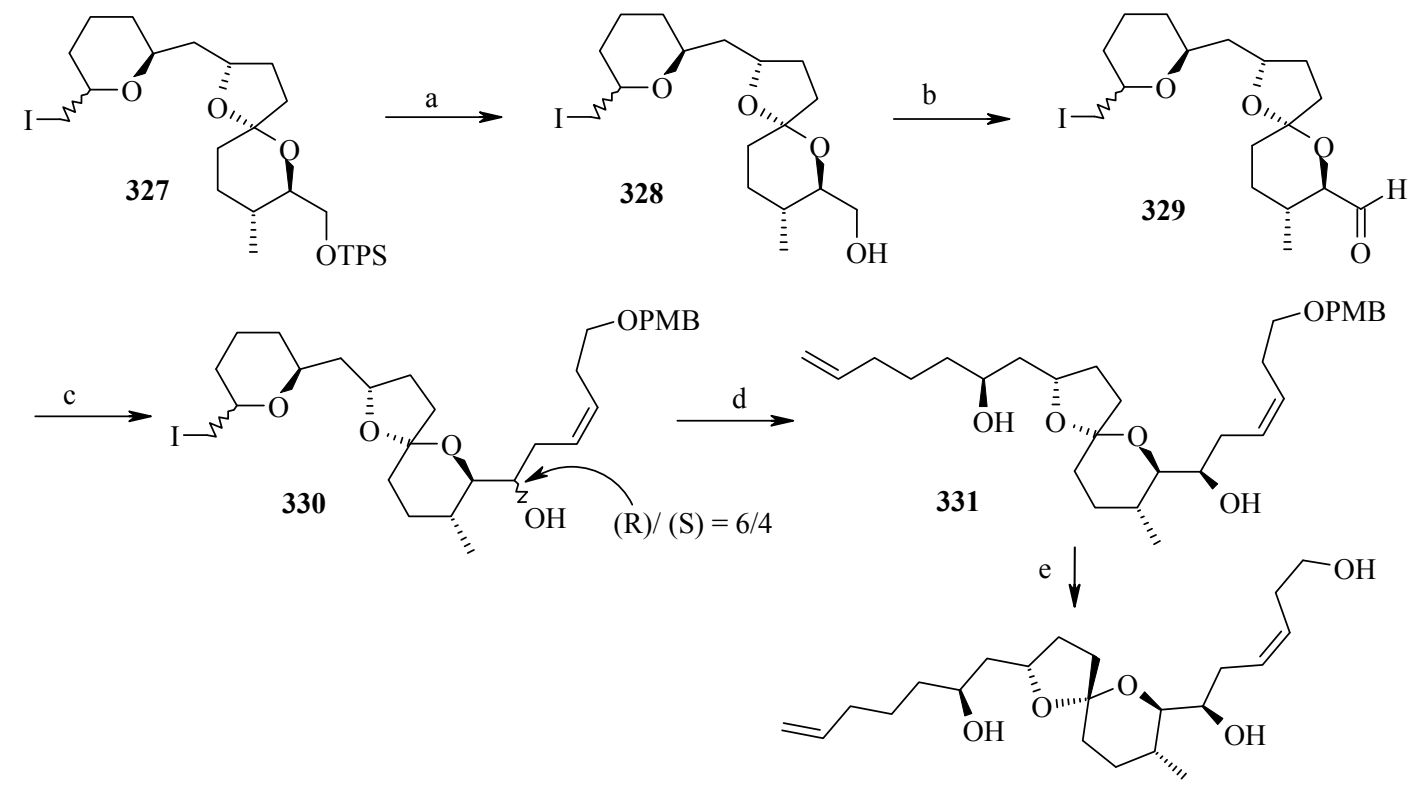

Attenol A

Reagents and conditions: (a) TBAF (1.2 equiv), THF, $20{ }^{\circ} \mathrm{C}, 24 \mathrm{~h}, 80 \%$; (b) Dess-Martin periodinane, pyridine, $\mathrm{CH}_{2} \mathrm{Cl}_{2}, 20^{\circ} \mathrm{C}, 2.5 \mathrm{~h}$; (c) (E) $-\mathrm{Bu}_{3} \mathrm{Sn}-\mathrm{CH}_{2} \mathrm{CH}=\mathrm{CHCH}_{2} \mathrm{CH}_{2} \mathrm{OPMB}, \mathrm{SnCl}_{4}, \mathrm{CH}_{2} \mathrm{Cl}_{2},-78{ }^{\circ} \mathrm{C}(330$ (R)) $35 \%$ and $\left(\boldsymbol{S}\right.$-330) 30\% (2 steps); (d) BuLi (3 equiv), $-78{ }^{\circ} \mathrm{C}, 3 \mathrm{~h}, 60 \%$ (25\% 330 recovered); (e) DDQ, $\mathrm{CH}_{2} \mathrm{Cl}_{2}, \mathrm{H}_{2} \mathrm{O}, 20^{\circ} \mathrm{C}, 30 \mathrm{~min}, 60 \%$.

\subsubsection{Enders Synthesis}

Enders et al. have provided a short enantioselective total synthesis of attenol A based on asymmetric alkylation of SAMP-hydrazones as well as a Sharpless asymmetric dihydroxilation as key steps [141]. 
The retrosynthetic analysis is shown in Scheme 74. It reveals that the key dithiane unit $\mathbf{3 3 2}$ can be cyclised to give attenol A after dethoketalysation and acid catalyzed spiroketalization. The unit 332 can be prepared from 333 and $\mathbf{3 3 4}$. Compounds 333 and 334 can be prepared by asymmetric alkylation using the SAMP-hydrazone methodology [142].

Scheme 74. Retrosynthetic analysis of attenol A.

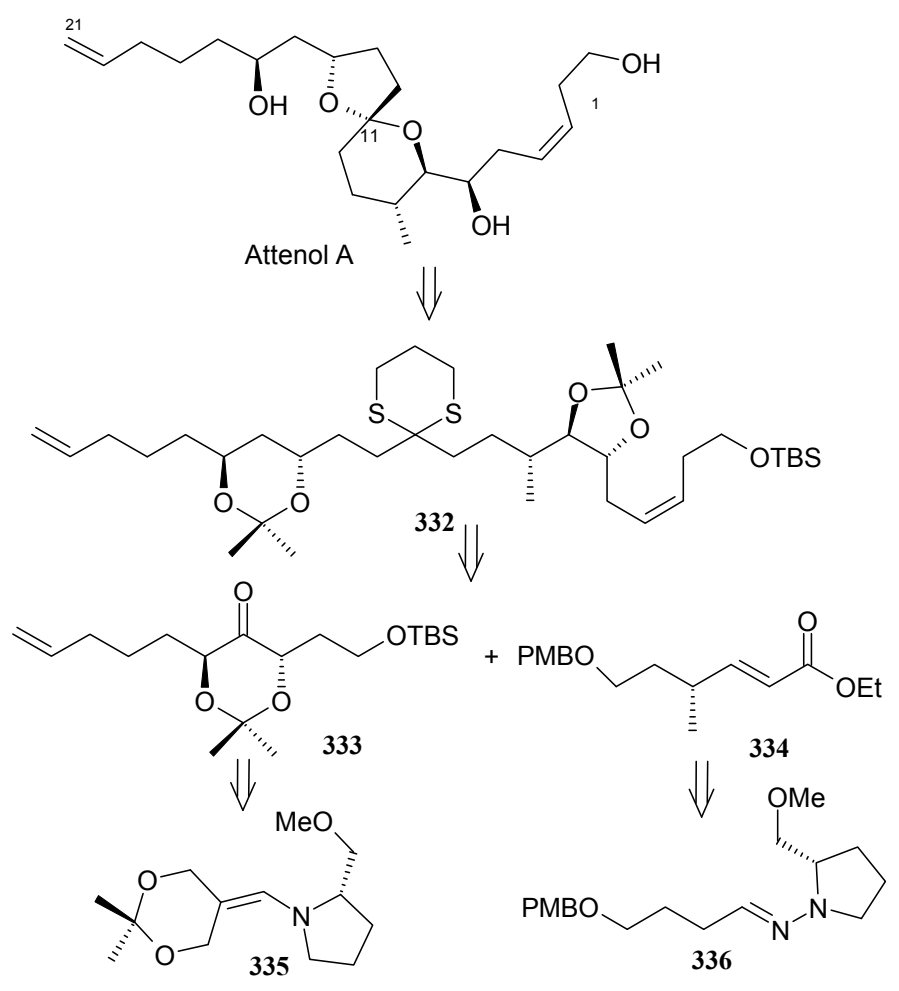

The anti-2,2-dimethyl-1,3-dioxan-5-one $\mathbf{3 3 3}$ is prepared from 2,2-dimethyl-1,3-dioxan-5-one SAMP-hydrazone 335. The alkylation of $\mathbf{3 3 5}$ with (2-bromoethoxy)-tert-butyldimethylsilane and 5bromopent-1-ene affords 337, which on deprotection of the hydrazone gives $\mathbf{3 3 3}$. Compound 333 is converted to alcohol 339 via xanthate 338 (Scheme 75). The alcohol 339 is converted to its iodide 340. Next the aldehyde 341 is converted to its hydrazone 336 by reacting with SAMP. Methylation with MeI affords 342 with $96 \%$ de. Ozonolysis of the hydrazone followed by Wittig reaction gives unit 334, which is subjected to Sharpless asymmetric dihydroxilation to give a mixture of diastereomers $\mathbf{3 4 3}$ [143]. The cis-diol is protected as its acetonide and the ester group is reduced to alcohol. The resulting alcohol is converted to triflate $\mathbf{3 4 5}$ and then treated with lithiated tert-butyl-3-ynylozxydimethylsilane to give alkyne 346. The compound 346 is then converted to 347 by reduction, deprotection and iodination (Scheme 76). 
Scheme 75. Synthesis of iodide 340.<smiles>C=CCCCC1OC(C)(C)O[C@H](CCCC=C)C1OC(C)=S</smiles>

Reagents and conditions: (a) $t$-BuLi, THF, $-78^{\circ} \mathrm{C}$, then (2-bromoethoxy)-tert-butyldimethylsilane, $-100{ }^{\circ} \mathrm{C}$ to $25{ }^{\circ} \mathrm{C}$; (b) $t$-BuLi, THF, $-78{ }^{\circ} \mathrm{C}$, then 5 -bromopent-1-ene, $-100{ }^{\circ} \mathrm{C}$, to $25{ }^{\circ} \mathrm{C}$; (c) oxalic acid, $\mathrm{Et}_{2} \mathrm{O}, 25{ }^{\circ} \mathrm{C}$, $75 \%$; (d) $\mathrm{NaBH}_{4}, \mathrm{MeOH}, 0{ }^{\circ} \mathrm{C}$; (e) $\mathrm{NaH}$, THF, $\mathrm{CS}_{2}$, MeI, $0{ }^{\circ} \mathrm{C}$, to $25{ }^{\circ} \mathrm{C}, 96 \%$; (f) $\mathrm{Bu}_{3} \mathrm{SnH}$, AIBN, toluene, reflux; (g) TBAF, THF, $25^{\circ} \mathrm{C}, 91 \%$; (h) $\mathrm{Ph}_{3} \mathrm{P}$, imidazole, $\mathrm{I}_{2}, \mathrm{Et}_{2} \mathrm{O} / \mathrm{CH}_{3} \mathrm{CN}, 0{ }^{\circ} \mathrm{C}, 94 \%$.

Scheme 76. Synthesis of iodide 347.

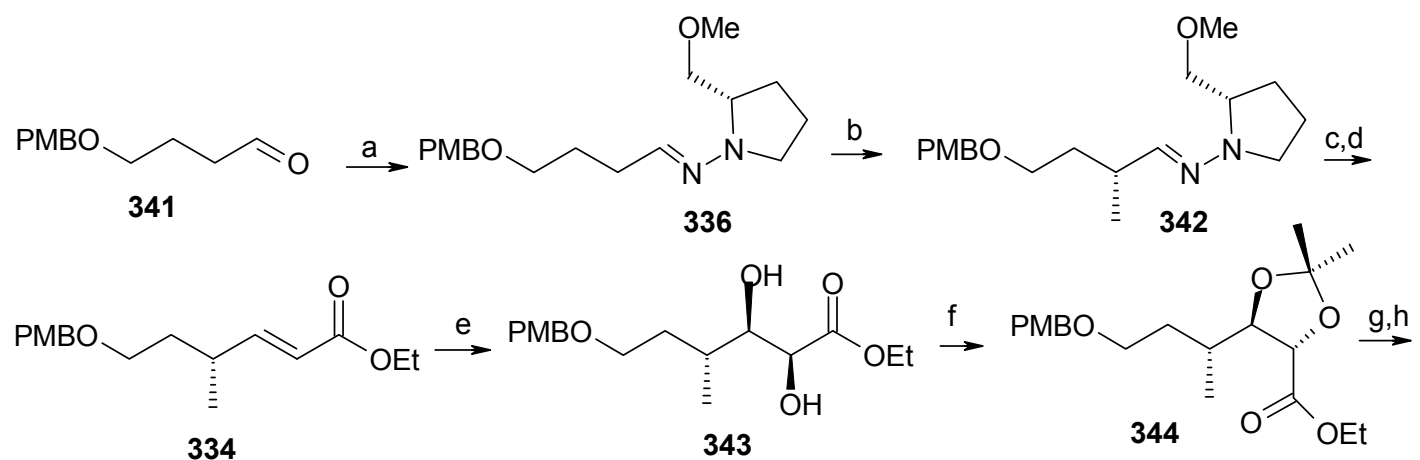

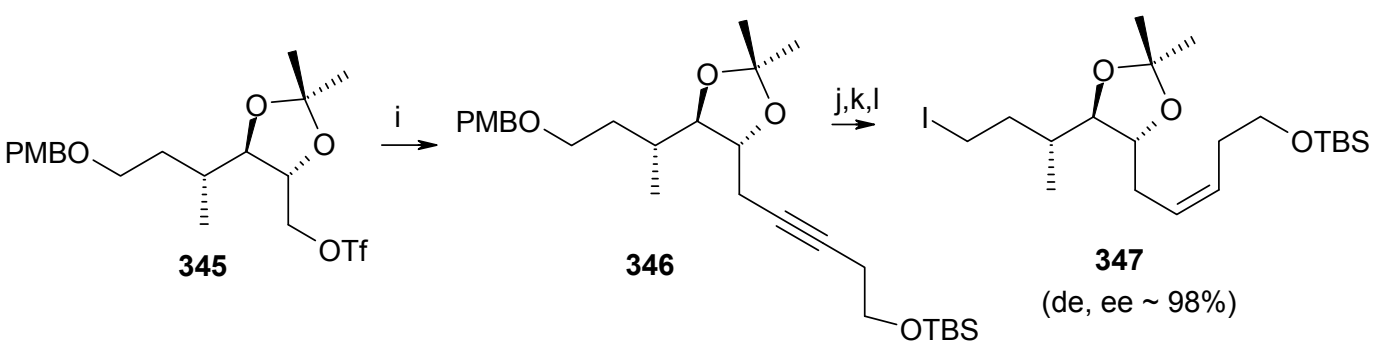

Reagents and conditions: (a) SAMP, $\mathrm{Et}_{2} \mathrm{O}, 0{ }^{\circ} \mathrm{C}$ to $25{ }^{\circ} \mathrm{C}, 95 \%$; (b) LDA, THF, $0{ }^{\circ} \mathrm{C}$, then MeI, $-120{ }^{\circ} \mathrm{C}$ to 25 ${ }^{\circ} \mathrm{C}, 86 \%$; (c) $\mathrm{O}_{3}, \mathrm{CH}_{2} \mathrm{Cl}_{2},-78{ }^{\circ} \mathrm{C}$; (d) $\mathrm{Ph}_{3} \mathrm{PCHCO}_{2} \mathrm{Et}, \mathrm{CH}_{2} \mathrm{Cl}_{2}, 25{ }^{\circ} \mathrm{C}, 71 \%$; (e) AD-mix $\beta, \mathrm{MeSO}_{2} \mathrm{NH}_{2}, t$ BuOH: $\mathrm{H}_{2} \mathrm{O}=1: 1,0{ }^{\circ} \mathrm{C}, 96 \%$; (f) 2,2-DMP, PTSA, $25{ }^{\circ} \mathrm{C}, 94 \%$; (g) LAH, Et $2 \mathrm{O}, 0{ }^{\circ} \mathrm{C}, 95 \%$; (h) $\mathrm{Tf}_{2} \mathrm{O}, 2,6$-ditert-butyl-4-methylpyridine, $\mathrm{CH}_{2} \mathrm{Cl}_{2},-40{ }^{\circ} \mathrm{C}$ to $-30{ }^{\circ} \mathrm{C}$; (i) tert-butylbut-3-ynyloxydimethylsilane, $t$-BuLi, THF, DMPU, $-78{ }^{\circ} \mathrm{C}$, then $345,-78{ }^{\circ} \mathrm{C}$ to $25^{\circ} \mathrm{C}, 89 \%$; (j) $\mathrm{H}_{2}$, Lindlar catalyst, $\mathrm{MeOH}, 25^{\circ} \mathrm{C}, 94 \%$; (k) DDQ, $\mathrm{CH}_{2} \mathrm{Cl}_{2}, 25{ }^{\circ} \mathrm{C}, 99 \%$; (1) $\mathrm{Ph}_{3} \mathrm{P}$, imidazole, $\mathrm{I}_{2}, \mathrm{Et}_{2} \mathrm{O} / \mathrm{CH}_{3} \mathrm{CN}, 0{ }^{\circ} \mathrm{C}, 83 \%$. 
Scheme 77. Total synthesis of attenol A.

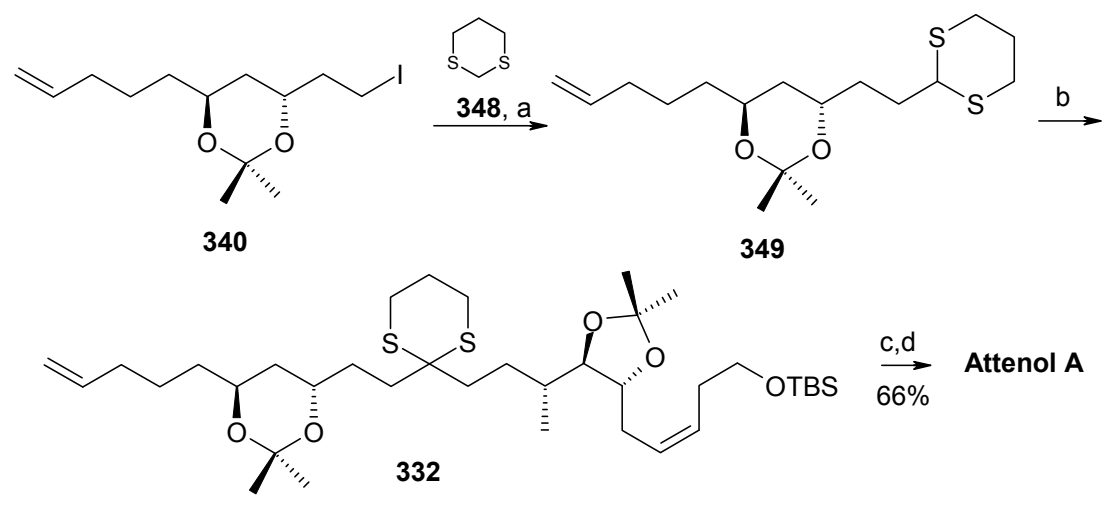

Reagents and conditions: (a) 348, $t$-Buli, THF, DMPU, $-78{ }^{\circ} \mathrm{C}, 96 \%$; (b) $t$-BuLi, THF, HMPA, $-78{ }^{\circ} \mathrm{C}$, then $347,-78^{\circ} \mathrm{C}$ to $25^{\circ} \mathrm{C}, 84 \%$; (c) $\mathrm{CuO}, \mathrm{CuCl}$, aq. $\mathrm{Me}_{2} \mathrm{CO}$, (d) PTSA, $\mathrm{MeOH}, 25^{\circ} \mathrm{C}, 66 \%$ over two steps.

The iodide 340 is treated with dithiane 348 to give $\mathbf{3 4 9}$, which is then subjected to a second alkylation with iodide 347 to afford the key intermediate 332 (Scheme 77). Finally, the copper catalysed hydrolysis of dithiane and acid catalyzed ketal formation gives attenol $\mathrm{A}$ as a major compound, along with minor amounts of attenol B.

\subsubsection{Suenaga and Uemura Synthesis}

Suenaga, Uemura and coworkers have synthesized attenol A by using diastereoselective hydroboration, coupling with lithium acetylide, Lindlar reduction and acid catalysed acetal formation [144]. The disconnection of the molecule reveals that ketone 350, which can be obtained from Julia reaction between fragments $\mathbf{3 5 1}$ and 352, is the key intermediate. Fragment $\mathbf{3 5 2}$ can be obtained from disubstituted alcohol 353 and alkyne 354 (Scheme 78).

The synthesis of fragment 352 starts with 2,3-O-isopropylidene-D-threitol 355. Monosilylation of 355 followed by oxidation gives aldehyde 356, which is converted to ketone 357 in two steps (Scheme 79). Wittig reaction of $\mathbf{3 5 7}$ followed by diastereoselective hydroboration with 9-BBN and oxidation with $\mathrm{H}_{2} \mathrm{O}_{2}$ provides alcohol $359(\alpha / \beta=8 / 1)$ with $(R)$ stereochemistry at $\mathrm{C}-8$. Oxidation of 359 followed by Horner-Emmons reaction affords conjugated ester $\mathbf{3 6 0}$ and hydrogenation of which gives saturated ester 361. Reduction of ester $\mathbf{3 6 1}$ to alcohol and then protection of alcohol as $p$-methoxybenzyl ether followed by desilylation of TBS group affords alcohol 353. The alcohol 353 is converted to triflate and then coupled with 4-tert-butyldimethylsilyloxy-1-butyne to give alkyne 363 . Reduction of 363 with Lindlar catalyst affords cis-olefin 364 of which MPM group is removed to give alcohol 365 . DessMartin oxidation of $\mathbf{3 6 5}$ affords the aldehyde fragment $\mathbf{3 5 2}$.

Synthesis of fragment 351 is started with alkylation of dithiane with 5-bromo-1-pentene (366) to give olefin 367. The second alkylation of dithiane with $(R)$-benzylglycidyl ether provides hydroxy ketone 368 after removal of dithiane group. Hydroxyketone $\mathbf{3 6 8}$ is then subjected to stereoselective reduction with tetramethylammonium triacetoxy-borohydride affords anti-diol 369 (88\%) along with minor amounts of syn-diol (10\%) [145]. 
Scheme 78. Retrosynthetic analysis of attenol A.

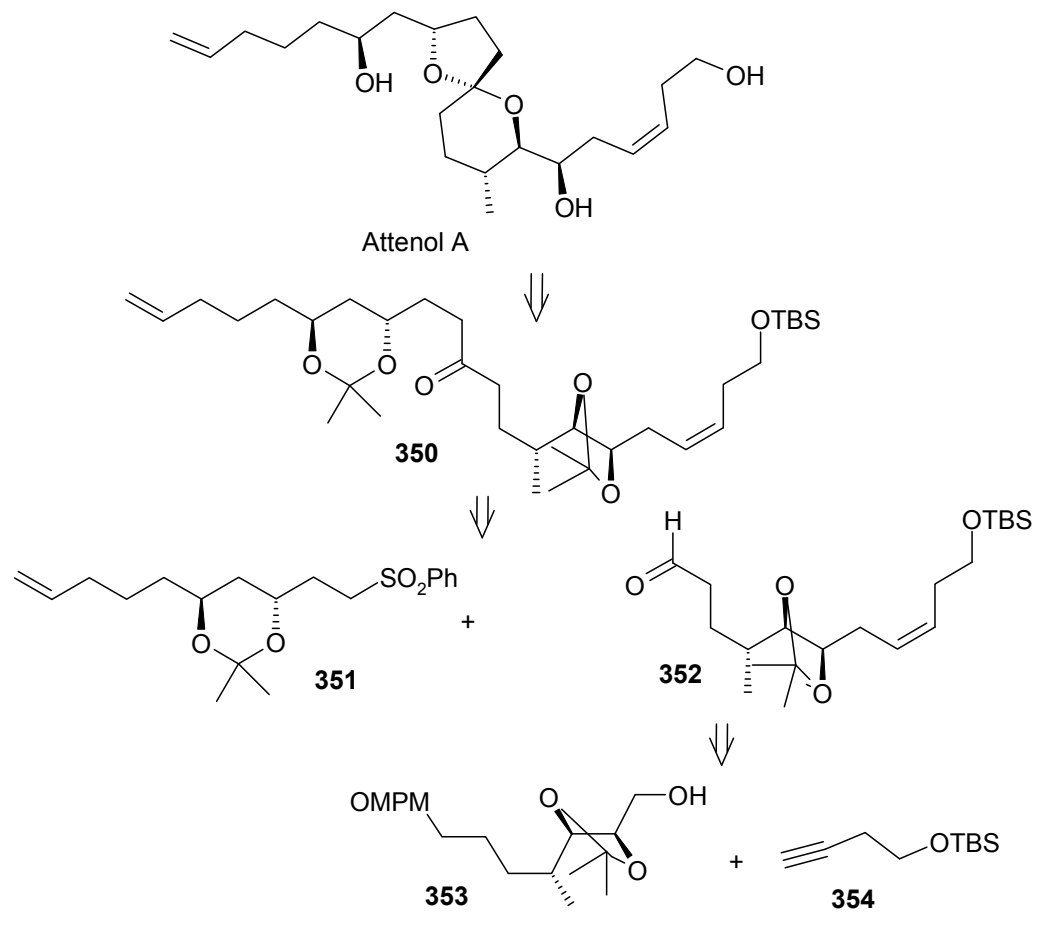

Scheme 79. Synthesis of right hand frgment 352.
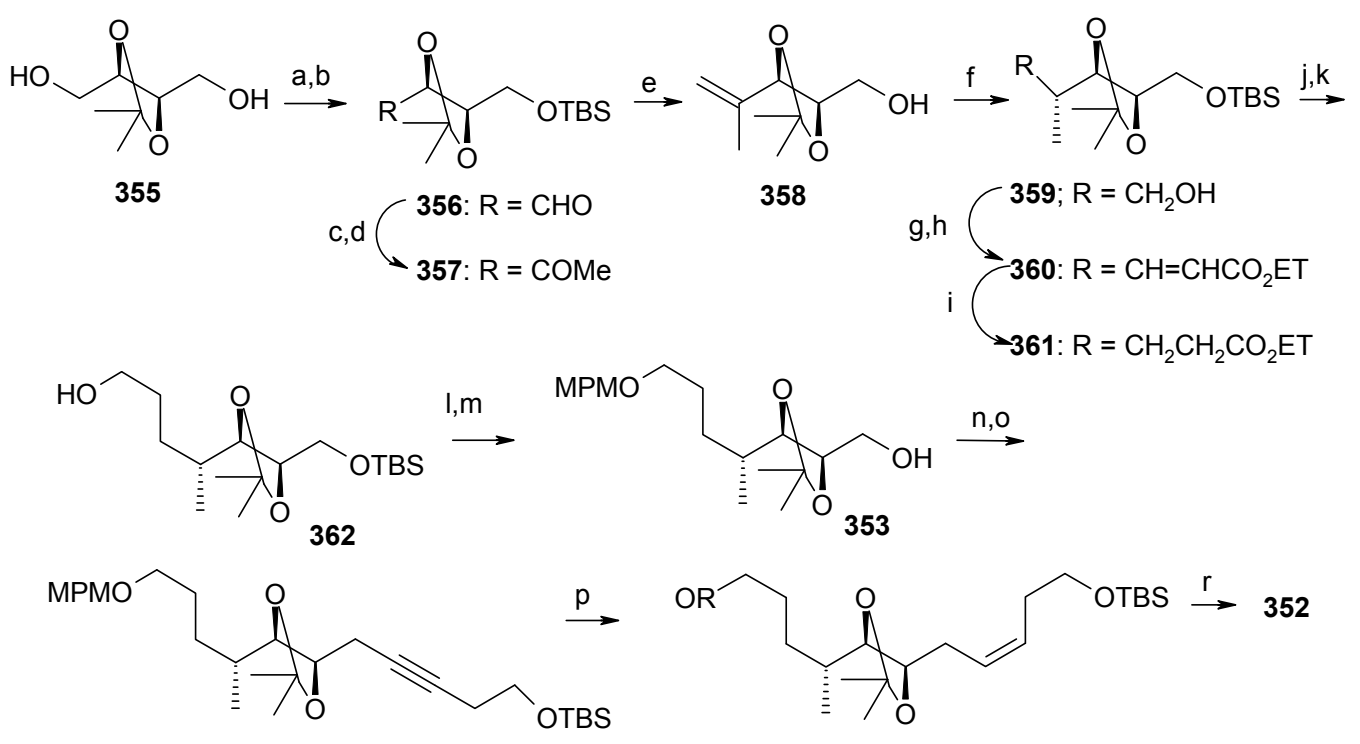

363

$q\left\{\begin{array}{l}364: R=M P M \\ 365: R=H\end{array}\right.$

Reagents and conditions: (a) TBSCl, NaH, DME, $0{ }^{\circ} \mathrm{C}$, to rt; (b) $(\mathrm{COCl})_{2}, \mathrm{DMSO}, \mathrm{CH}_{2} \mathrm{CL}_{2},-78{ }^{\circ} \mathrm{C}$, then $\mathrm{Et}_{3} \mathrm{~N},-78{ }^{\circ} \mathrm{C}$ to rt; (c) $\mathrm{MeLi}$, CuI, $\mathrm{Et}_{2} \mathrm{O},-78{ }^{\circ} \mathrm{C}$ to $0{ }^{\circ} \mathrm{C}$; (d) $(\mathrm{COCl})_{2}$, DMSO, $\mathrm{Et}_{3} \mathrm{~N},-78{ }^{\circ} \mathrm{C}$ to $0{ }^{\circ} \mathrm{C}$; (e) $\mathrm{Ph}_{3} \mathrm{PCH}_{3} \mathrm{Br}$, BuLi, $-40{ }^{\circ} \mathrm{C}$ to $0{ }^{\circ} \mathrm{C}$; (f) 9-BBN, THF, $0{ }^{\circ} \mathrm{C}$ to rt, then $\mathrm{H}_{2} \mathrm{O}_{2}$, NaOAc, aq.; (g) Dess-Martin periodinane, $\mathrm{CH}_{2} \mathrm{Cl}_{2}$, rt; (h) (EtO) ${ }_{2} \mathrm{P}(\mathrm{O}) \mathrm{CH}_{2} \mathrm{CO}_{2} \mathrm{Et}$, $t$-BuOK, THF, $-78{ }^{\circ} \mathrm{C}$ to $0{ }^{\circ} \mathrm{C}$; (i) $\mathrm{H}_{2}, 5 \%, \mathrm{Rh}-\mathrm{Al}_{2} \mathrm{O}_{3}$, EtOAc, rt; (j) DIBALH, $\mathrm{CH}_{2} \mathrm{Cl}_{2},-78{ }^{\circ} \mathrm{C}$; (k) $\mathrm{NaBH}_{4}$, EtOH, $0{ }^{\circ} \mathrm{C}$; (l) MPMCl, NaH, DMF, $-20{ }^{\circ} \mathrm{C}$; (m) $\mathrm{Bu}_{4} \mathrm{NF}$, THF, rt; (n) $\mathrm{Tf}_{2} \mathrm{O}$, 2,6-di-tert-butyl-4-methylpyridine, $\mathrm{CH}_{2} \mathrm{Cl}_{2}, \quad-20{ }^{\circ} \mathrm{C}$; (o) 4-tertbutyldimethylsiloloxy-1-butyne, BuLi, HMPA, THF, $-78^{\circ} \mathrm{C}$, then triflate, $-35{ }^{\circ} \mathrm{C}$, to rt; (p) $\mathrm{H}_{2}$, Lindlar cat., $\mathrm{MeOH}$, rt; (q) DDQ, $\mathrm{CH}_{2} \mathrm{Cl}_{2}, t$-BuOH-phosphate buffer(pH 6); (r) Dess-Martin periodinane, $\mathrm{CH}_{2} \mathrm{Cl}_{2}$, rt. 
Scheme 80. Synthesis of left hand fragment 351.

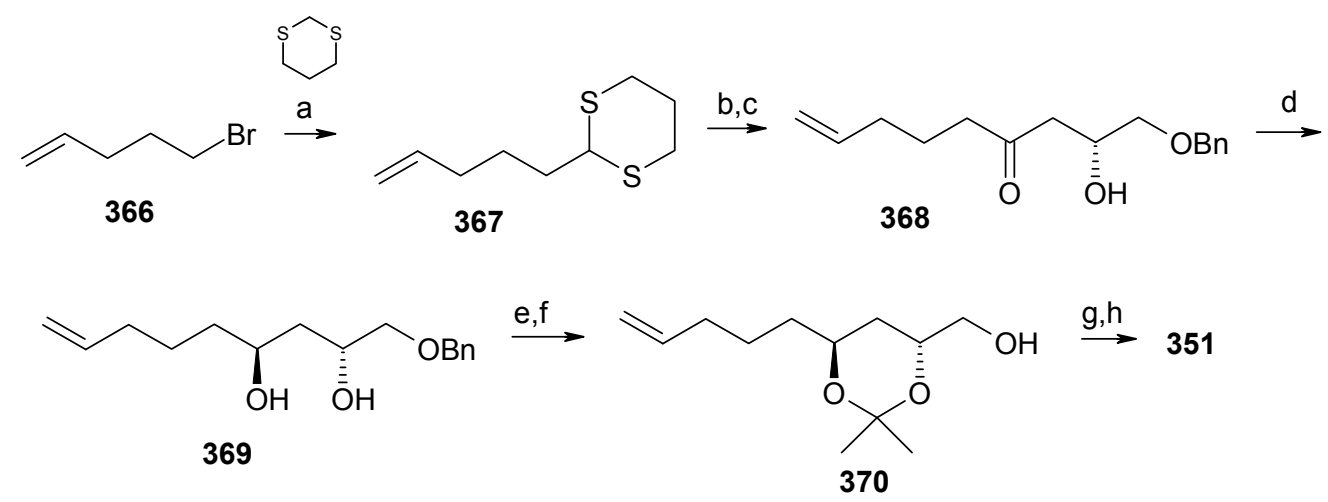

Reagents and conditions: (a) BuLi, THF, $-78^{\circ} \mathrm{C}$ to rt, (b) BuLi, (R)-benzylglycidyl ether, THF, $-78{ }^{\circ} \mathrm{C}$ to $\mathrm{rt}$; (c) $\mathrm{CuCl}_{2}, \mathrm{CuO}, \mathrm{Me}_{2} \mathrm{CO}-\mathrm{H}_{2} \mathrm{O}$, rt; (d) $\mathrm{Me}_{4} \mathrm{NHB}(\mathrm{OAc})_{3}, \mathrm{MeCN}-\mathrm{AcOH},-40$ to $-30{ }^{\circ} \mathrm{C}$; (e) $\mathrm{Me}_{2} \mathrm{C}(\mathrm{OMe})_{2}, \mathrm{CSA}$, $\mathrm{Me}_{2} \mathrm{CO}$, rt; (f) Na, liq $\mathrm{NH}_{3}$, THF, $-78{ }^{\circ} \mathrm{C}$; (g) $p$-TsCl, $\mathrm{Py}, 0^{\circ} \mathrm{C}$; (h) $\mathrm{MeSO}_{2} \mathrm{Ph}, \mathrm{BuLi}$, THF, reflux.

Acetonide protection of diol $\mathbf{3 6 9}$ followed by deprotection of benzyl group furnishes alcohol 370, which is converted to fragment $\mathbf{3 5 1}$ after tosylation followed by reaction with methyl phenyl sulfone (Scheme 80). The Julia reaction of fragments 351 and $\mathbf{3 5 2}$ followed by oxidation and reduction gives ketone 350 the key intermediate for the synthesis of attenol A. Finally the spiroketalisation is achieved by deprotecting with PPTS in methanol in one step (Scheme 81).

Scheme 81. Total synthesis of attenol A.

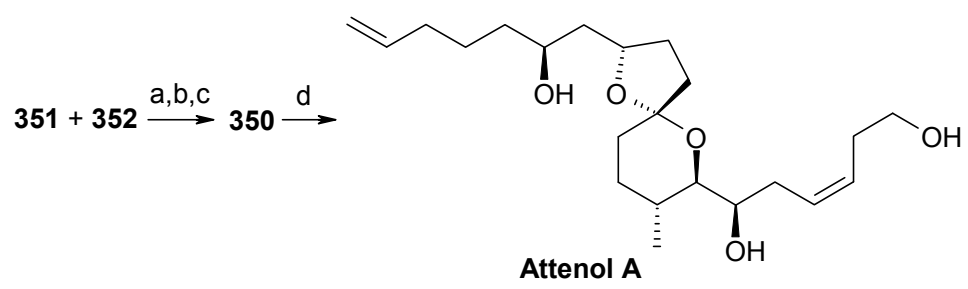

Reagents and conditions: (a) 351, BuLi, THF, $-78{ }^{\circ} \mathrm{C}$, then 352, $-78{ }^{\circ} \mathrm{C}$; (b) Dess-Martin periodinane, Py, $\mathrm{CH}_{2} \mathrm{Cl}_{2}$, rt; (c) $5 \% \mathrm{Na}-\mathrm{Hg}, \mathrm{Na}_{2} \mathrm{HPO}_{4}, \mathrm{MeOH}, 0^{\circ} \mathrm{C}$; (d) PPTS, $\mathrm{MeOH}$, rt.

\subsubsection{Rychnovsky Synthesis}

Recently Rychnovosky et al. have reported the total synthesis of attenol A using a reductive cyclisation approach [146]. This reductive cyclisation strategy facilitates the stereoselective assembly of nonanomeric spiroacetals [147]. The advantage of this strategy over the traditional spiroacetal syntheses is that it gives rise to a single nonanomeric stabilized [5.4]-spiroacetal, which equilibrates under acidic conditions to the more stable anomeric epimer [147]. As a result both epimers can be accessed from the same intermediate.

The retrosynthetic pathway is shown in Scheme 82, which reveals that the right hand side chain can be obtained by a vinyl cuprate addition to spiroketal unit 371, obtained from non-anomeric spiroketal $\mathbf{3 7 2}$ by acid treatment. The unit $\mathbf{3 7 2}$ can be obtained from reductive lithiation of cyanoacetal $\mathbf{3 7 3}$, 
which in turn can be obtained from spiroorthoester 374. Spiroester 374 can be prepared from chiral molecules 375 and 376.

Scheme 82. Retrosynthetic analysis of attenol A.

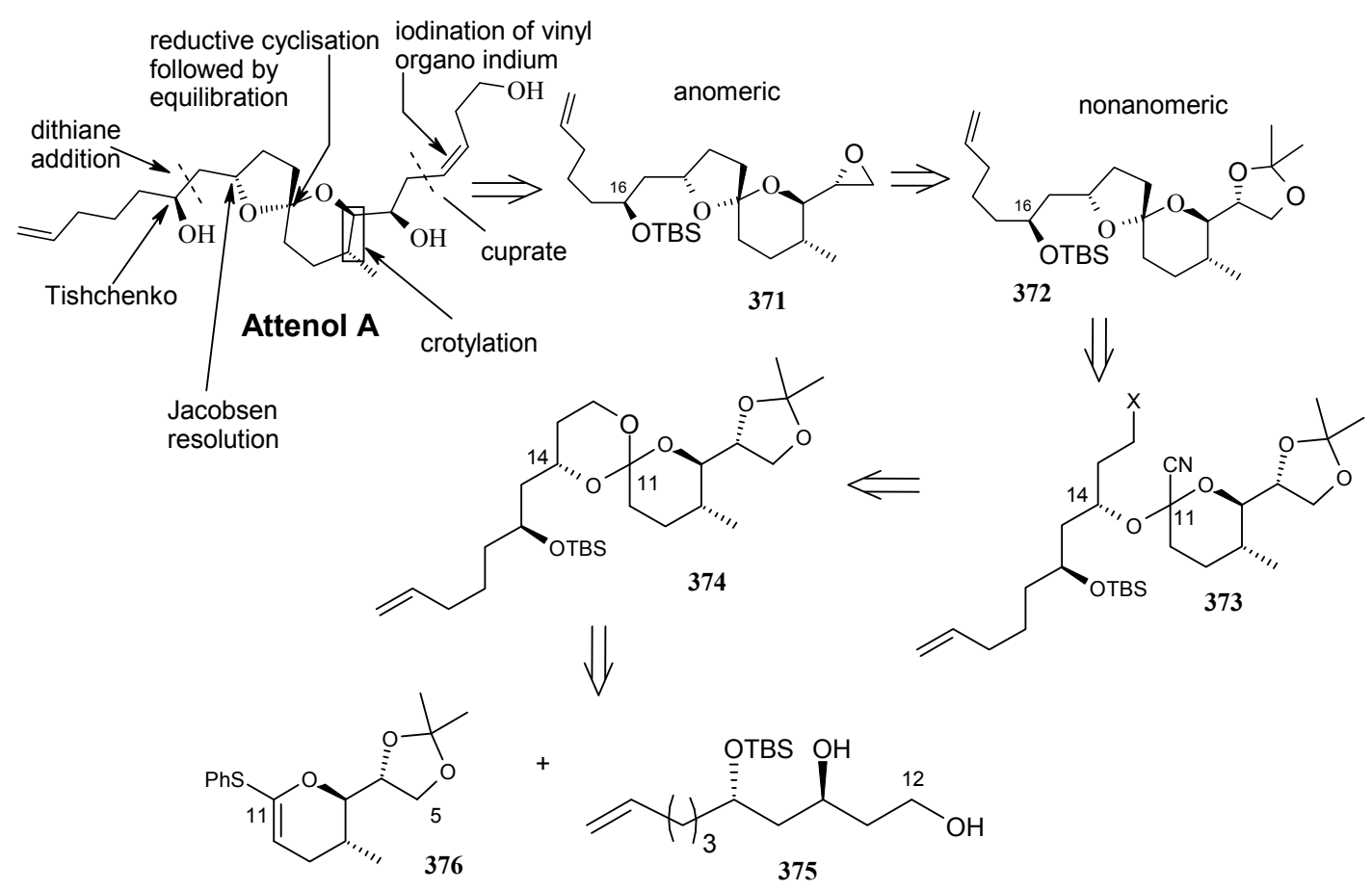

The preparation of diol 375 starts with optically pure epoxide 378, obtained by Jacobson resolution [148]. Epoxide 378 is treated with lithiated dithiane 377 to give alcohol 379, which upon hydrolysis with aqueous MeI affords hydroxyketone 380. Reduction of ketone $\mathbf{3 8 0}$ using Schneider's conditions at $-78{ }^{\circ} \mathrm{C}$ gives desired anti ester 381 with good stereoselectivity (98:2) [149]. Ester 381 is converted to diol 375 after protection and deprotection sequence (Scheme 83).

Scheme 83. Synthesis of diol 375.

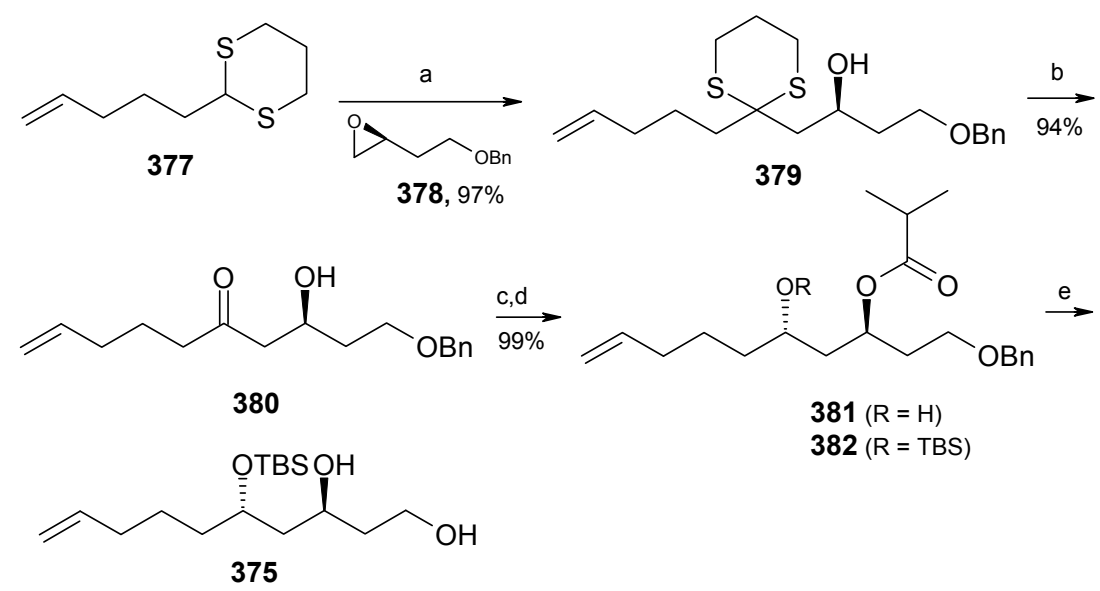

Reagents and conditions: (a) $n$ - $\mathrm{BuLi}, 378,97 \%$; (b) $\mathrm{CaCO}_{3}, \mathrm{MeI}, \mathrm{MeCN} / \mathrm{H}_{2} \mathrm{O}, 94 \%$; (c) $\mathrm{Zr}(\mathrm{O}-t-\mathrm{Bu})_{4}$, $i$-PrCHO, 83\%, 98:2 dr; (d) TBSOTf, 99\%; (e) MeLi, THF/NH3 $/ \mathrm{Li}(0), 92-99 \%$. 
Scheme 84. Synthesis of organocuprate 384.

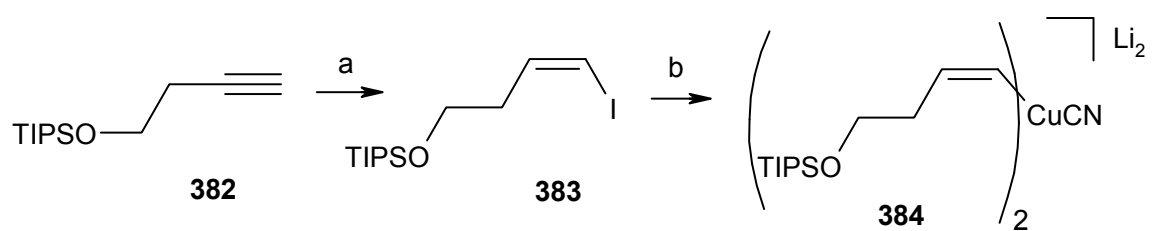

Reagents and conditions: (a) $\mathrm{InCl}_{3}, \mathrm{Et}_{3} \mathrm{~B}, \mathrm{I}_{2}, 83 \%$; (b) $n$-BuLi, $\mathrm{CuCN}$.

Next the right hand side chain unit vinyl cuprate $\mathbf{3 8 4}$ is prepared from alkyne $\mathbf{3 8 2}$ in two steps (Scheme 84) [150]. Thioketene acetal 376 is prepared starting from homoallylic alcohol $\mathbf{3 8 5}$. Alcohol 385 is converted to vinyl ester 386, which upon treatment with Grubbs' second generation catalyst and subsequent hydrogenation gives lactone 388 [151]. Desired thioketene acetal 376 is obtained after application of Koscienski's Ni(0) protocol (Scheme 86) [152].

The thioketene acetal 376 is coupled with diol 375 to give orthoester 374, which is subjected to ring opening with $\mathrm{BF}_{3} \cdot \mathrm{Et}_{2} \mathrm{O}$ and TMSCN to give alcohol 390 as a single diastereomer [147]. The alcohol 390 is then converted to phosphate ester 391 (Scheme 85) [153].

The phosphate ester 391 is reductively cyclised with lithium di-tert-butylbiphenylide (LiDBB) to give nonanomeric spiroacetal 372 as a major product along with anomeric spiroacetal 392 and 393 as minor products (Scheme 87) [154].

Scheme 85. Synthesis of thioketene aceatal 376.

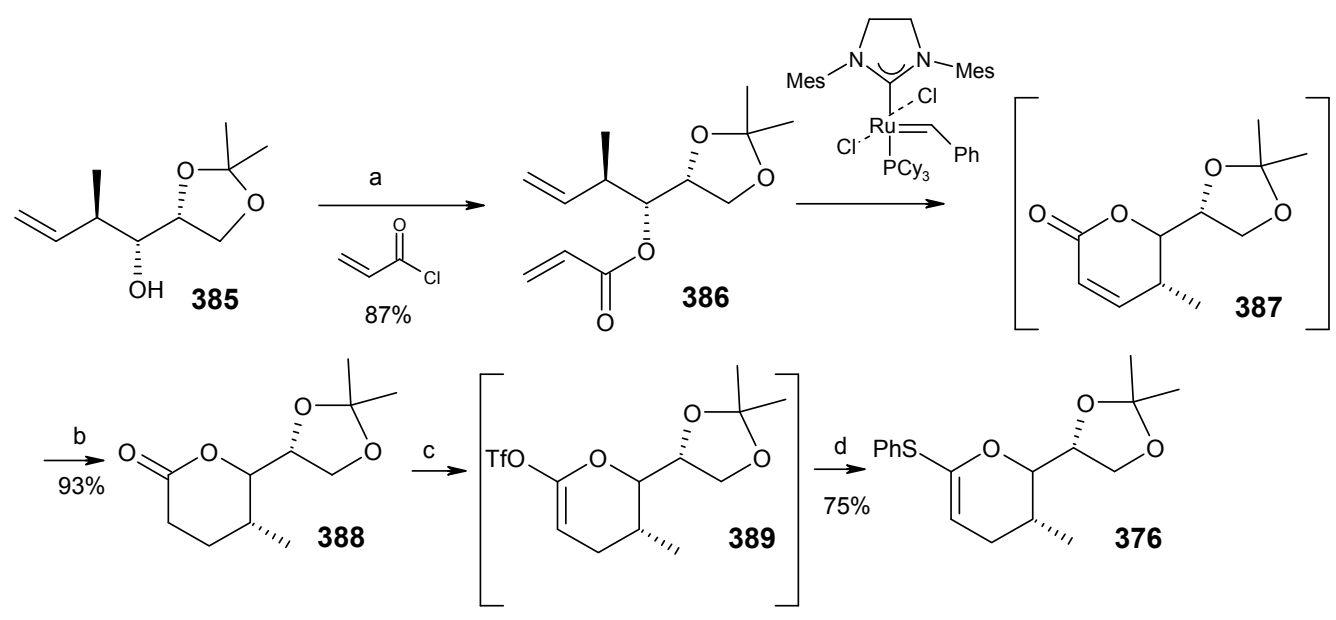

Reagents and conditions: (a) (iPr) $)_{2} \mathrm{NEt}$, DMAP, 87\%; (b) $\mathrm{H}_{2}, 100$ psi, 93\%; (c) KHMDS, PhN(Tf) ${ }_{2}$ (d) $\mathrm{Ni}(0), \mathrm{PhSNa}, 75 \%$. 
Scheme 86. Synthesis of phosphate ester 391.

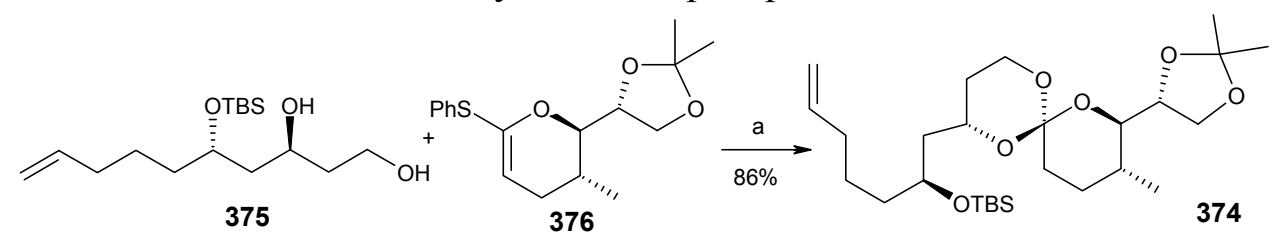

375 376<smiles>C=CCCCC(C[C@@H](CCOP(=O)(OC)OCC)OC1(C)CC[C@@H](C)[C@H]([C@H]2COC(C)(C)O2)O1)OCC</smiles>

374<smiles>C=CCCCC(C[C@@H](CCO)OC1(C#N)CC[C@@H](C)C([C@H]2COC(C)(C)O2)O1)O[Na]</smiles>
390 391

Reagents and conditions: (a) CSA, 86\%; (b) $\mathrm{BF}_{3} \cdot \mathrm{Et}_{2} \mathrm{O}$, TMSCN, 71\%; (c) (EtO) ${ }_{2} \mathrm{P}(\mathrm{O}) \mathrm{Cl}, 97 \%$.

Scheme 87. Reductive cyclisation of 391.

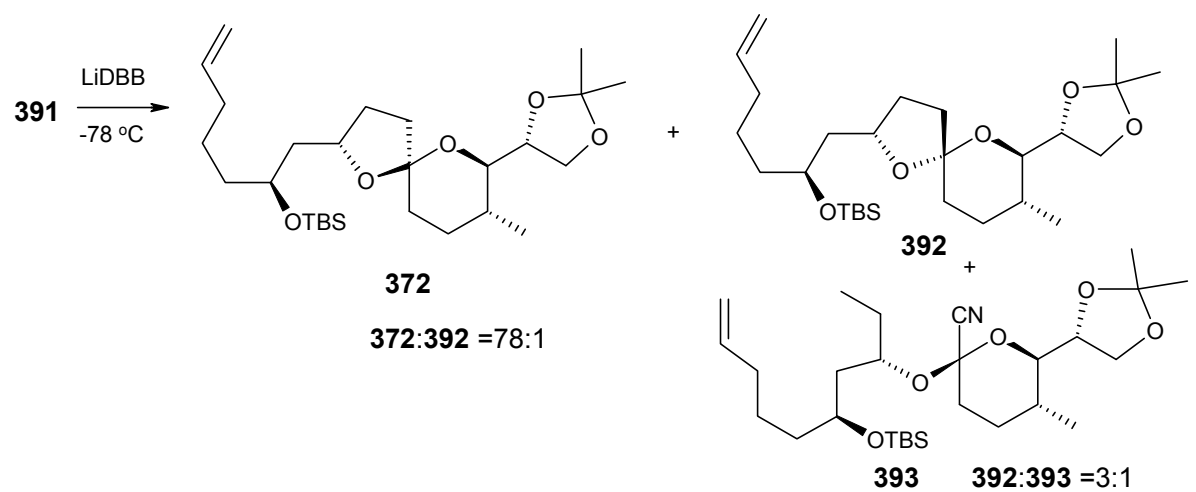

The nonanomeric spiroacetal 372 is treated with PPTS in methanol to bring about equilibrium conditions to give anomeric spiroacetal 392 along with 393. The spiroacetal 392 is then epoxidized using the Sharpless-Moffat protocol to give epoxide 371 [155]. The epoxide 371 is treated with vinyl cuprate 384 to afford alcohol 394. Finally, the TIPS silyl group is removed to furnish the natural product attenol A (Scheme 88).

Scheme 88. Total synthesis of attenol A.

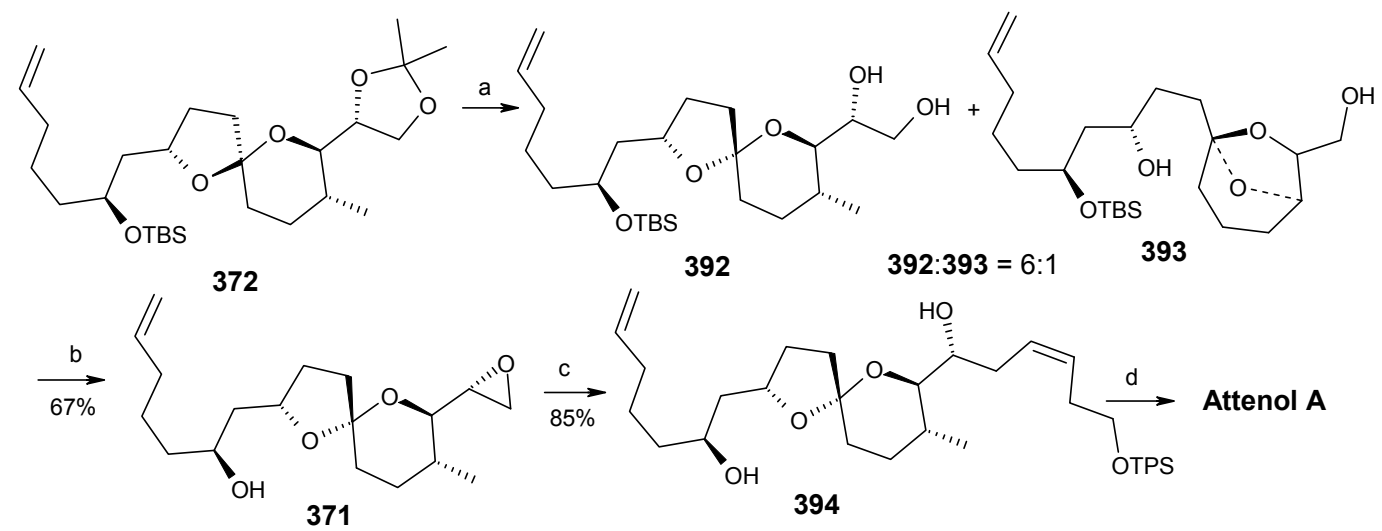

Reagents and conditions: (a) PPTS, $\mathrm{MeOH}$; (b) (i) PPTS, $\mathrm{MeC}(\mathrm{OMe})_{3}$, (ii) $\mathrm{AcBr}$, (iii) $\mathrm{MeOH}, \mathrm{K}_{2} \mathrm{CO}_{3}, 67 \%$; (c) Cuprate 384, 87\%; (d) TBAF. 
The Weghe and Eustache approach utilizes silicon tethered coupling metathesis for the synthesis of spiroketal unit. Although the synthesis was completed in 15 steps, it suffers from low yield in the metathesis step. Enders and Suenaga/Uemura, on the other hand, use an acid catalyzed spirocyclisation strategy for spiroketal synthesis from suitably protected keto alcohol. They completed the synthesis in 15 and 22 steps with $19 \%$ and $16.4 \%$ overall yield, respectively. Rychnovsky achieved the synthesis of attenol $\mathrm{A}$ in 13 (longest linear sequence) steps with $21.4 \%$ overall yield. This is a more efficient route than previously reported methods. An important feature of this synthesis is that it uses the nontraditional reductive cyclisation approach for construction of anomeric spiroacetal unit. This is the first report for isolation of an anomeric spiroacetal from reductive cyclisation reaction.

\subsection{Stereoselective Total Synthesis of Bistramide A}

Bistramides, A-D and $\mathrm{K}$, constitute a novel class of bioactive marine natural products that were isolated from the marine ascidian Lissoclinum bistratum [126]. It is also believed that bistramide A can inhibit nucleotide exchange by stabilizing the closed actin conformation [156]. These promising biological activities of bistramide A have manifested it as a potential candidate for anticancer therapy. The bistramide A skeleton consists of a substituted tetrahydropyran and spiroketal subunit connected by a central $\gamma$-amino acid linker.

\subsubsection{Yadav Synthesis}

Yadav et al. have reported the total synthesis of bistramide $\mathrm{A}$ in which the construction of the spiroketal unit is achieved by hydrolysis of dialkylated tosylmethyl isocyanide derivative derived via alkylation of TosMIC with suitably substituted halohydrin derivatives [157].

Scheme 89. Retrosynthetic analysis of bistramide A.

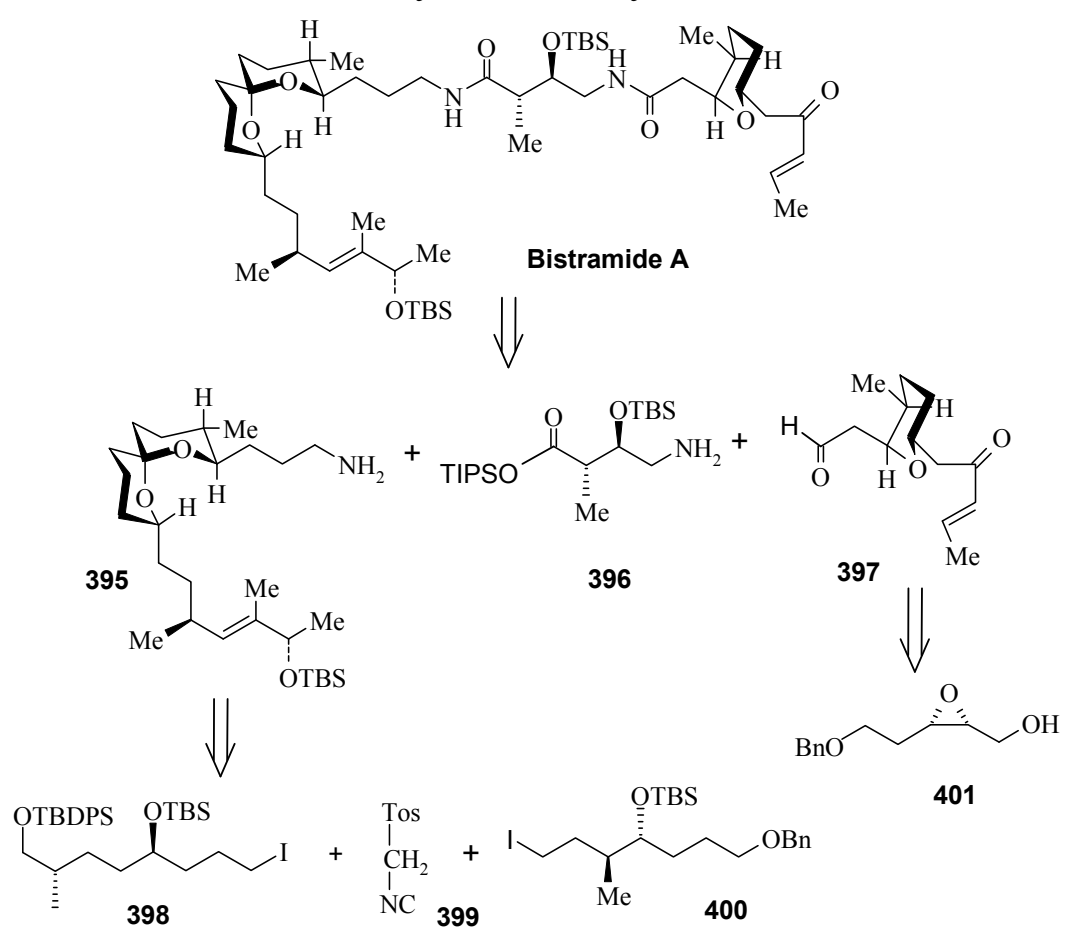


The retrosynthetic analysis of the molecule is shown in Scheme 89. It shows that the molecule is composed of three units; spiroketal fragment 395, $\gamma$-amino acid fragment 396 and pyran fragment 397. Fragment 395 can be obtained from 399 by alkylation of iodides 398 and $\mathbf{4 0 0}$ (Scheme 89).

The synthesis of unit 400 starts with allyl alcohol $\mathbf{4 0 2}$. Alcohol 402 is converted to lactone 403 over three steps $[158,159]$. The lactone $\mathbf{4 0 3}$ is reduced to the corresponding diol with $\mathrm{LiAlH}_{4}(82 \%)$ of which the primary hydroxyl group of the diol is protected as its pivalate ester and the secondary hydroxyl group as TBS ether to furnish 404. Deprotection of the pivalate ester and subsequent treatment with iodine and triphenylphosphine affords iodo compound $\mathbf{4 0 0}$ (Scheme 90).

Scheme 90. Synthesis of iodide fragment $\mathbf{4 0 0 .}$

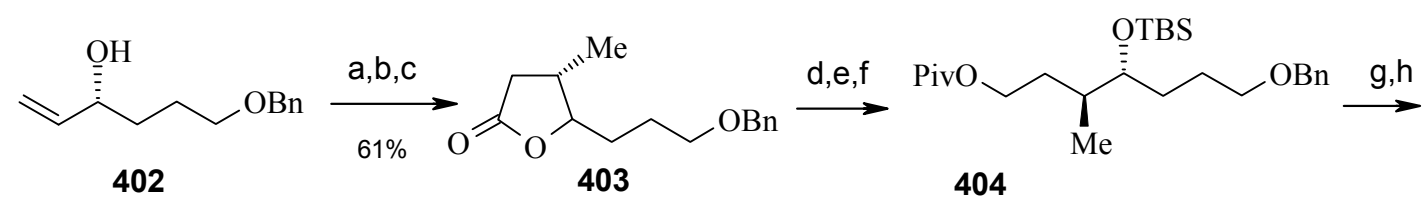<smiles>C[C@@H](CCI)[C@@H](CCCOc1ccccc1)O[Na]</smiles>

Reagents and conditions: (a) $\mathrm{CH}_{2}=\mathrm{CHOEt}, \mathrm{NBS}, \mathrm{CH}_{2} \mathrm{Cl}_{2}$; (b) $\mathrm{Bu}_{3} \mathrm{SnH}, \mathrm{AIBN}$, benzene; (c) Jones reagent, $\mathrm{Me}_{2} \mathrm{CO}, 61 \%$; (d) $\mathrm{LiAlH}_{4}, \mathrm{Et}_{2} \mathrm{O}, 82 \%$; (e) PivCl, $\mathrm{Et}_{3} \mathrm{~N}, \mathrm{CH}_{2} \mathrm{Cl}_{2}, 86 \%$; (f) TBSOTf, 2,6-lutidine, $\mathrm{CH}_{2} \mathrm{Cl}_{2}$, 97\%; (g) DIBALH, toluene, $-78^{\circ} \mathrm{C}, 88 \%$; (h) $\mathrm{I}_{2}, \mathrm{Ph}_{3} \mathrm{P}$, imidazole, THF, 94\%.

Compound 398 is synthesized starting from dithiane 405 [160]. Reaction of lithiated dithiane 405 with epoxide 406 affords an alcohol, which is protected as its TBS ether to give 407. Removal of dithiane as well as benzyl group with Raney-nickel under a $\mathrm{H}_{2}$ atmosphere affords the primary alcohol, which is converted into corresponding iodo compound 398 (Scheme 91).

Scheme 91. Synthesis of iodide fragment 398.

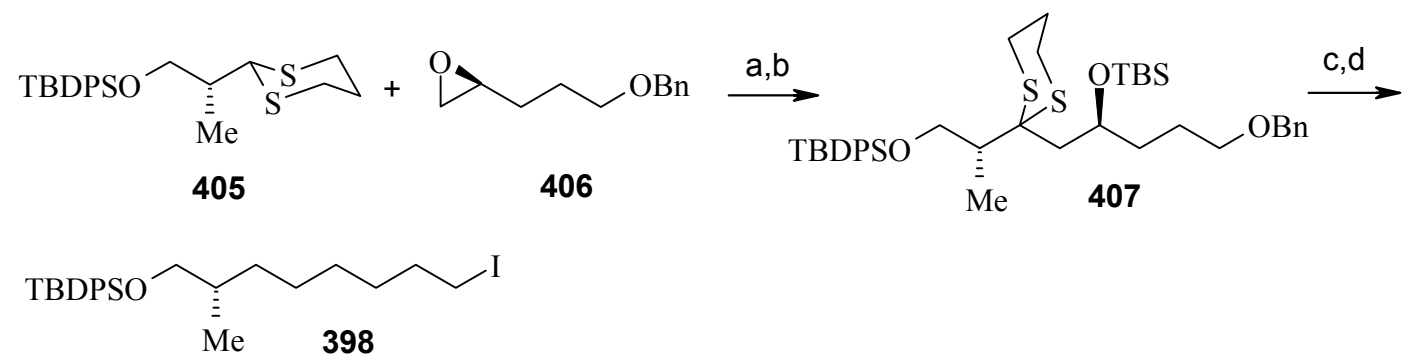

Reagents and conditions: (a) $n$-BuLi, THF, $-20{ }^{\circ} \mathrm{C}$ to $\mathrm{rt}, 72 \%$; (b) TBSOTf, 2,6-lutidine, $\mathrm{CH}_{2} \mathrm{Cl}_{2}, 96 \%$; (c) Raney Ni, $\mathrm{H}_{2}$, EtOH, 75\%; (d) $\mathrm{I}_{2}, \mathrm{Ph}_{3} \mathrm{P}$, imidazole, THF, $90 \%$.

Synthesis of spiroketal fragment 395 of bistramide A starts with TosMIC 399 (Scheme 92). Dialkylation of TosMIC 399 with iodo compounds 400 and 398 in the presence of $n$-BuLi affords dialkylated product, which on treatment with aq. HF affords spiroketal 409 (85\%) [161]. Compound 409 is converted to an $\alpha, \beta$-unsaturated ketone 410 using Swern oxidation and Horner-Wadsworth- 
Emmons olefination [162]. The ketone $\mathbf{4 1 0}$ is reduced with Corey's chiral oxazaborolidine to afford allyl alcohol, which is protected as TBS ether to give 411 [163]. The compound 411 is converted to spiroketal fragment 395 in three steps [164].

Scheme 92. Synthesis of spiroketal fragment 395.

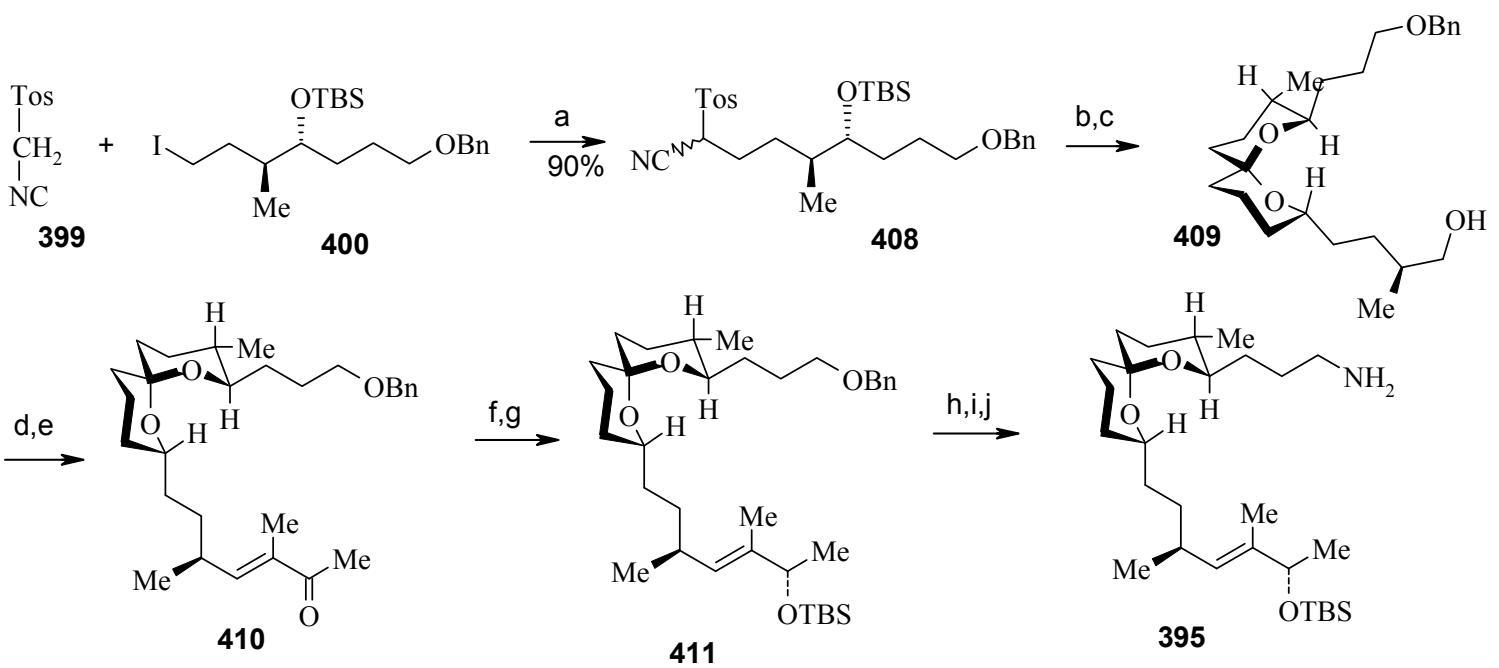

Reagents and conditions: (a) $n$-BuLi, HMPA, THF, $-78{ }^{\circ} \mathrm{C}$ to rt, $90 \%$; (b) $n$-BuLi, HMPA, THF then 398, $78{ }^{\circ} \mathrm{C}$ to rt, 83\%; (c) aq. $\mathrm{HF}, \mathrm{MeOH}$, THF, 85\%; (d) $(\mathrm{COCl})_{2}, \mathrm{DMSO}, \mathrm{Et}_{3} \mathrm{~N}, \mathrm{CH}_{2} \mathrm{Cl}_{2},-78{ }^{\circ} \mathrm{C}$; (e) $\mathrm{MeCOCH}(\mathrm{Me}) \mathrm{P}(\mathrm{OEt})_{2}, \mathrm{Ba}(\mathrm{OH})_{2}$, THF, 63\%; (f) $(R)$-CBS, catecholborane, toluene, 93\%; (g) TBSOTf, 2,6lutidine, $\mathrm{CH}_{2} \mathrm{Cl}_{2}, 91 \%$; (h) $\mathrm{Na}, \mathrm{NH}_{3}$ (l), THF, $89 \%$; (i) $\mathrm{Ph}_{3} \mathrm{P},\left(\mathrm{C}_{6} \mathrm{H}_{5} \mathrm{O}\right)_{2} \mathrm{P}(\mathrm{O}) \mathrm{N}_{3}$, DIAD, THF, 85\%; (j) $\mathrm{PMe}_{3}$, $\mathrm{THF} / \mathrm{H}_{2} \mathrm{O}$.

The $\gamma$-amino acid fragment 396 is synthesized as shown in Scheme 93. The anti aldol adduct $\mathbf{4 1 4}$ obtained from previously reported procedure is converted into the corresponding Weinreb amide 415 after protecting the free hydroxyl group as TBS ether $[165,166]$.

Scheme 93. Synthesis of $\gamma$-amino acid fragment 396.
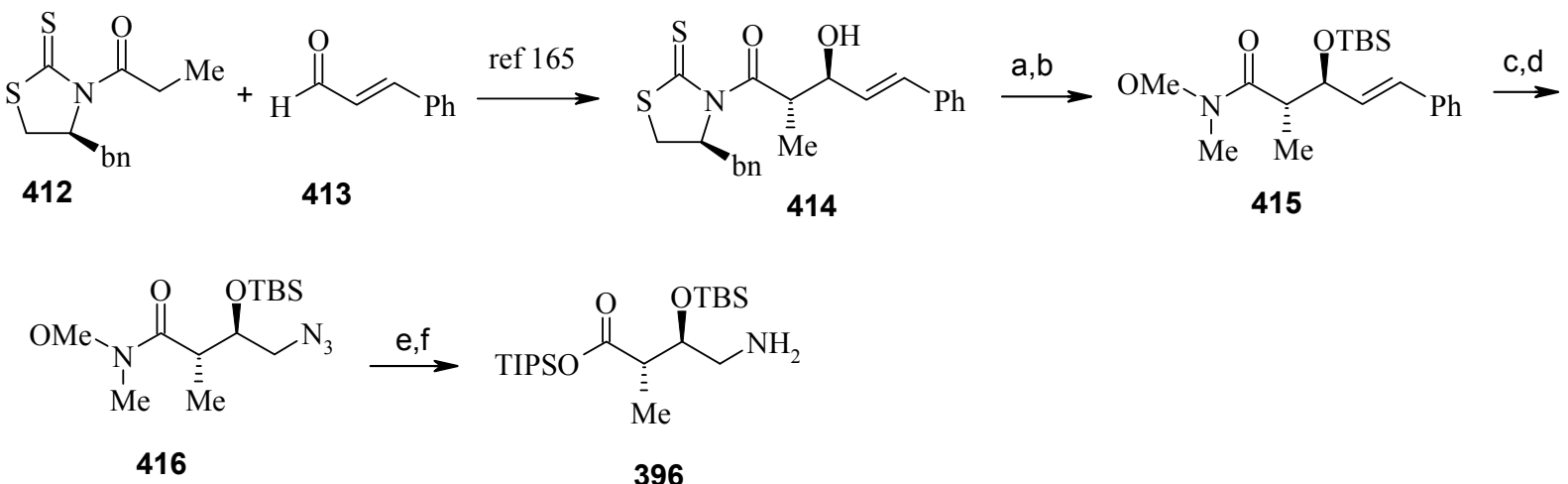

Reagents and conditions: (a) $\mathrm{MeO}(\mathrm{H}) \mathrm{NMe} . \mathrm{HCl}$, imidazole, $\mathrm{CH}_{2} \mathrm{Cl}_{2}, 84 \%$; (b) TBSOTf, 2,6-lutidine, $\mathrm{CH}_{2} \mathrm{Cl}_{2}$, 95\%; (c) $\mathrm{O}_{3}, \mathrm{CHCl}_{3}, \mathrm{Ph}_{3} \mathrm{P}, \mathrm{MeOH}, \mathrm{NaBH}_{4}, 75 \%$; (d) $\mathrm{Ph}_{3} \mathrm{P},\left(\mathrm{C}_{6} \mathrm{H}_{5} \mathrm{O}\right)_{2} \mathrm{P}(\mathrm{O}) \mathrm{N}_{3}$, DIAD, THF, 80\%; (e) (i) $\mathrm{KO}{ }^{t} \mathrm{Bu}, \mathrm{THF}, \mathrm{H}_{2} \mathrm{O}$, (ii) TIPSOTf, $\mathrm{CH}_{2} \mathrm{Cl}_{2}, \mathrm{Et}_{3} \mathrm{~N}, 72 \%$; (f) $\mathrm{H}_{2}, \mathrm{Pd} / \mathrm{C}$, THF. 
Ozonolysis of $\mathbf{4 1 5}$ followed by reduction with $\mathrm{NaBH}_{4}$ affords a primary alcohol, which is then converted into the corresponding azide 416 by using $(\mathrm{PhO})_{2} \mathrm{P}(\mathrm{O}) \mathrm{N}_{3}$ under Mitsunobu conditions. The azide 416 is then converted into $\gamma$-amino acid fragment 396 in three steps.

Scheme 94. Synthesis of pyran fragment 397.

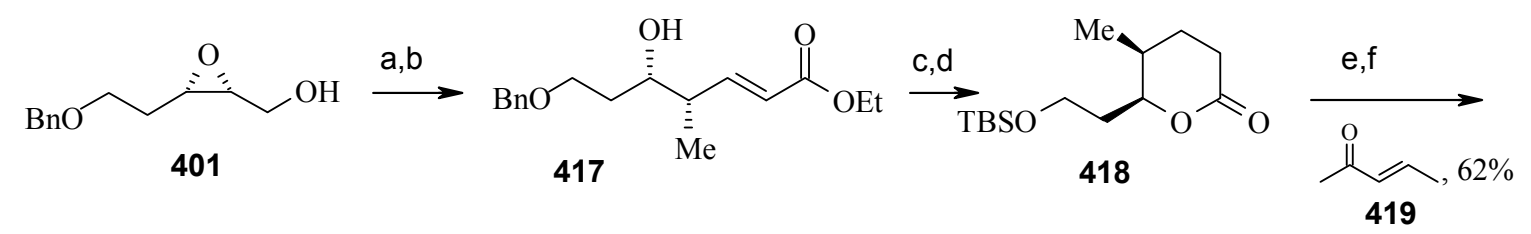<smiles>C/C=C/C(=O)O[C@H](CC(=O)O)[C@H](C)CC(=O)O</smiles>

Reagents and conditions: (a) (i) $(\mathrm{COCl})_{2}, \mathrm{DMSO}, \mathrm{Et}_{3} \mathrm{~N}, \mathrm{CH}_{2} \mathrm{Cl}_{2}$, (ii) $\mathrm{Ph}_{3} \mathrm{PCHCO}_{2} \mathrm{Et}$, benzene, $90 \%$; (b) $\mathrm{Me}_{3} \mathrm{Al}, \mathrm{CH}_{2} \mathrm{Cl}_{2}, \mathrm{H}_{2} \mathrm{O}, 92 \%$; (c) (i) Raney Ni, $\mathrm{H}_{2}$, EtOH, (ii) PPTS, $\mathrm{CH}_{2} \mathrm{Cl}_{2}, 78 \%$; (d) TBSCl, imidazole, $\mathrm{CH}_{2} \mathrm{Cl}_{2}, 93 \%$; (e) DIBALH, $\mathrm{CH}_{2} \mathrm{Cl}_{2}$, Py, DMAP, $\mathrm{Ac}_{2} \mathrm{O}, 78 \%$; (f) TMSOTf, $\mathrm{Et}_{3} \mathrm{~N}, \mathrm{CH}_{2} \mathrm{Cl}_{2}, 419,62 \%$; (g) $\mathrm{H}_{5} \mathrm{IO}_{6} / \mathrm{CrO}_{3}, \mathrm{MeCN}$.

Synthesis of pyran fragment 397 starts with known cis epoxy alcohol 401, which is converted in two steps to the $\gamma, \delta$-epoxy acrylate, which in turn is subjected to reaction with $\mathrm{Me}_{3} \mathrm{Al}$ following Miyashita's protocol to furnish the syn product 417 regio- and stereoselectively $[167,168]$.

Treatment of $\mathbf{4 1 7}$ with Raney-nickel gives a mixture of hydroxyl ester and lactone, the hydroxy ester on treatment with PPTS affords the lactone exclusively [169]. The free hydroxyl group of lactone is protected as TBS ether to give compound 418. The lactone $\mathbf{4 1 8}$ is converted to acetate following the Rychnovsky's protocol, which upon treatment with ketone 419 affords $\mathbf{4 2 0}$. Oxidation of 420 gives the pyran fragment 397 (Scheme 94) [170].

Scheme 95. Total synthesis of bistramide A.

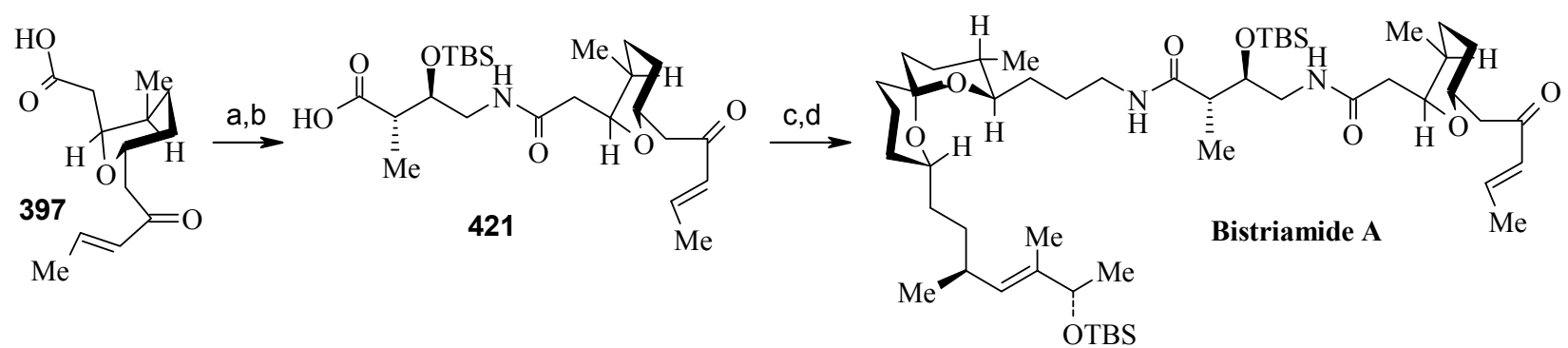

Reagents and conditions: (a) PyBOP, $\mathrm{Et}_{3} \mathrm{~N}, \mathrm{CH}_{2} \mathrm{Cl}_{2}, 396,62 \%$; (b) TBAF, THF, 89\%; (c) PyBOP, DIPEA, DMF, 395, 65\%; (d) PPTS, MeOH, 79\%.

Finally all three fragments 395, 396, and 397 are coupled to obtain bistramide A (Scheme 95). Coupling of tetrahydropyran subunit 397 and amine 396 in the presence of PyBOP gives TIPS ester, which is selectively deprotected with TBAF to afford acid 421. Finally, peptide coupling of acid $\mathbf{4 2 1}$ 
with amine 395 leads to the formation of silyl protected bistramide and removal of the silyl protecting group with PPTS affords bistramide A [164].

\subsubsection{Kozmin Synthesis}

Kozmin et al. have synthesized bistramide A using a flexible and convergent strategy [171]. In this synthesis the molecule is disconnected into three fragments: spiroketal fragment 422, amino acid fragment $\mathbf{4 2 3}$ and pyran fragment 424, as shown in Scheme 96. The spiroketal unit can be synthesized from polyol 425, which in turn can be synthesized from strained cyclopropene acetal 428 and homoallyl alcohol $\mathbf{4 2 7}$ and $\mathbf{4 2 9}$ by sequential ring opening/cross-metathesis.

Scheme 96. Retrosynthetic analysis bistramide A.

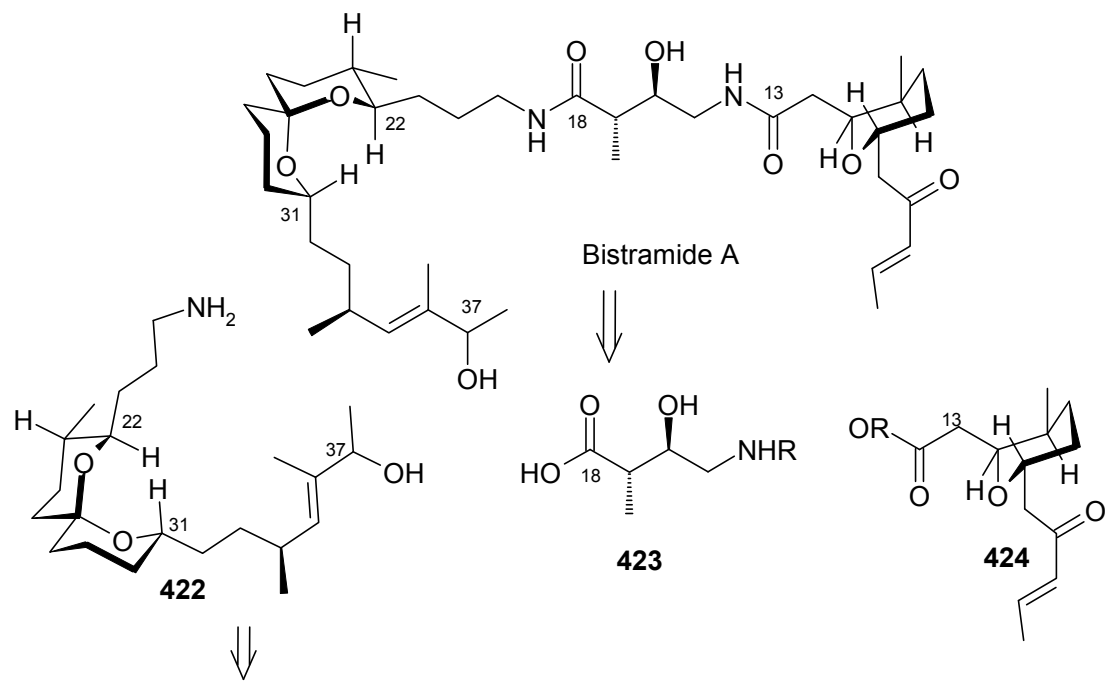<smiles>[R16]NCCC[C@@H](O)[C@H](C)CCC(=O)CCC[C@H](O)CC[C@H](C)CO</smiles>

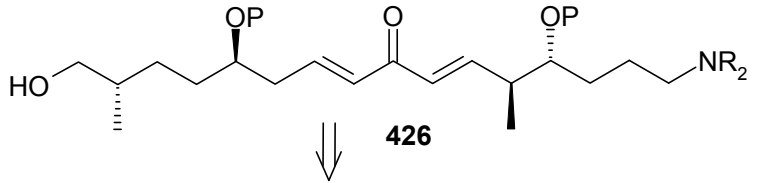<smiles></smiles>

The synthesis of spiroketal fragment $\mathbf{4 2 2}$ starts with ring opening metathesis of cyclopropene acetal 431 with alkene 430 [172]. Removal of the acetal under acidic conditions affords dienone 432, which after a second metathesis with $\mathbf{4 3 3}$ gives the desired cross-metathesis product 434 [173]. Treatment of 434 with hydrogen in the presence of $\mathrm{Pd}(\mathrm{OH})_{2} / \mathrm{C}$ reduces the double bond and deprotects the benzyl group at the same time to give a saturated hydroxyketone, which on oxidation affords spiroketal $\mathbf{4 3 5}$. The complete synthesis of fragment $\mathbf{4 2 2}$ is accomplished by $\mathrm{Cr}$-mediated olefination, Itsuno-Corey reduction, and phthalimide deprotection (Scheme 97) [174,175]. 
Scheme 97. Synthesis of spirioketal fragment $\mathbf{4 2 2}$.

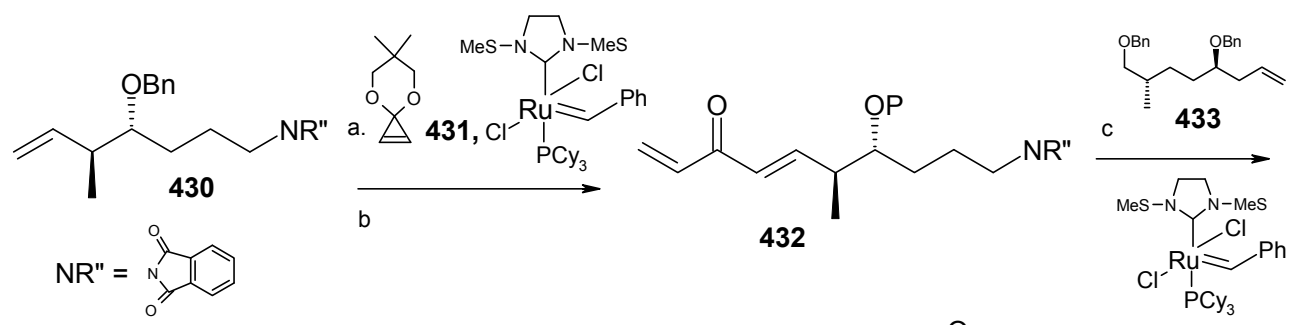

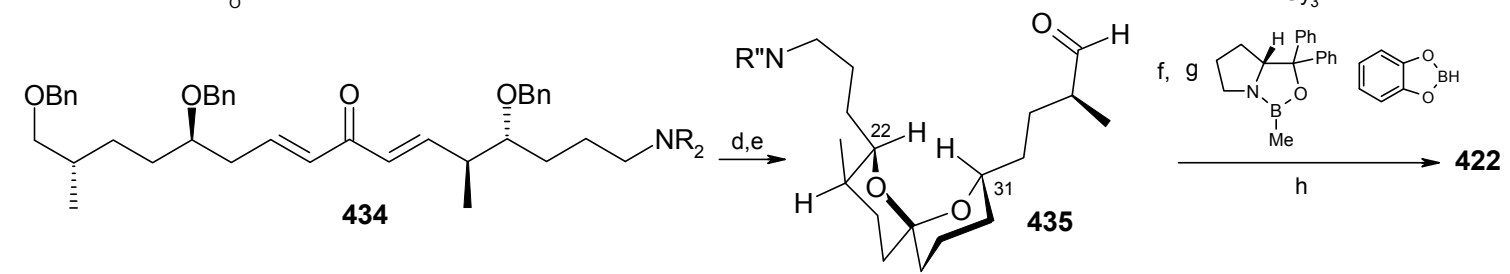

Reagents and conditions: (a) 431, Grubbs catalyst, benzene, $60{ }^{\circ} \mathrm{C}$; (b) $1 \mathrm{M} \mathrm{H}_{2} \mathrm{SO}_{4}, \mathrm{MeCN}, 63 \%$; (c) 433, Grubbs catalyst, 68\%; (d) $\mathrm{H}_{2}, \mathrm{Pd}(\mathrm{OH})_{2} / \mathrm{C}$; (e) Dess-Martin reagent, 53\%; (f) $\mathrm{CrCl}_{2} / \mathrm{THF}, \mathrm{CH}_{3} \mathrm{COCBr}_{2} \mathrm{CH}_{3}$; (g) boron reagent; (h) $\mathrm{MeNH}_{2}, \mathrm{MeOH}, 65^{\circ} \mathrm{C}, 40 \%$.

Scheme 98. Synthesis of Amino acid fragment 423.

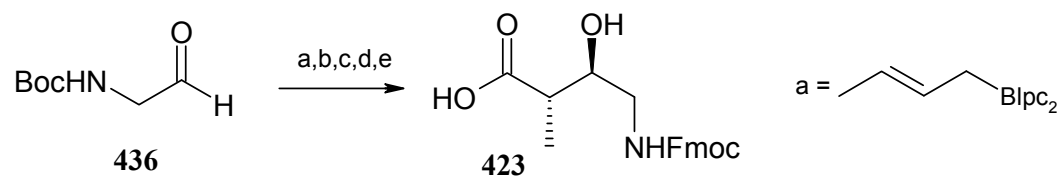

Reagents and conditions: (a) trans- $\mathrm{CH}_{3} \mathrm{CH}=\mathrm{CHCH}_{2} \mathrm{Blpc}_{2}$; (b) $\mathrm{Me}_{2} \mathrm{C}(\mathrm{OMe})_{2}$, PPTS; (c) $\mathrm{RuCl}_{3}, \mathrm{NaIO}_{4}$; (d) $3 \mathrm{M} \mathrm{HCl}$, EtOAc; (e) FmocOSu, dioxane- $\mathrm{H}_{2} \mathrm{O}, 25 \%$.

Scheme 99. Synthesis of pyran fragment 424.

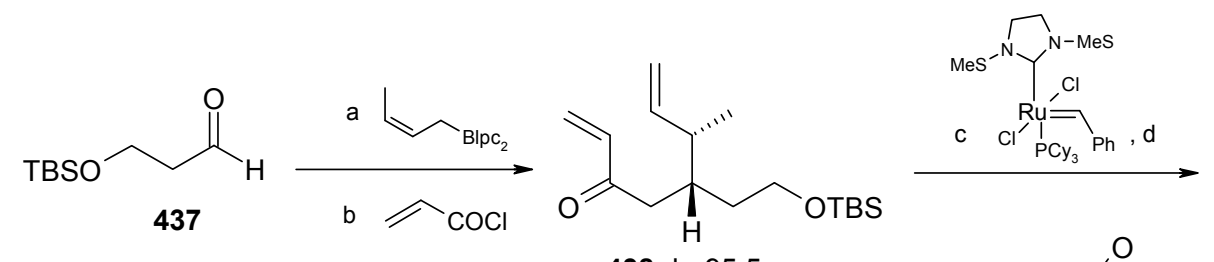
438 dr: $95: 5$

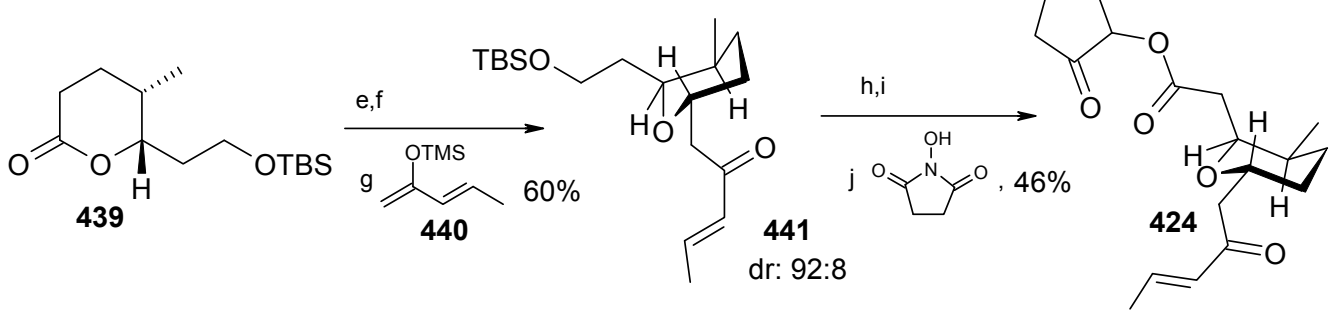

Reagents and conditions: (a) cis- $\mathrm{CH}_{3} \mathrm{CH}=\mathrm{CHCH}_{2} \mathrm{Blpc}_{2}$; (b) $\mathrm{CH}_{2}=\mathrm{CHCOCl}, \mathrm{Et}_{3} \mathrm{~N}$, DMAP, 55\%; (c) Grubbs catalyst; (d) $\mathrm{H}_{2}, \mathrm{Pd} / \mathrm{C}, 72 \%$; (e) DIBALH, $\mathrm{CH}_{2} \mathrm{Cl}_{2}$; (f) $\mathrm{Ac}_{2} \mathrm{O}, \mathrm{Py}$; (g) 440, $\mathrm{ZnCl}_{2}, 60 \%$; (h) HF, $\mathrm{MeCN}$; (i) $\mathrm{H}_{5} \mathrm{IO}_{6}, \mathrm{CrO}_{3}$; (j) DCC, THF, $46 \%$. 
Scheme 100. Total synthesis of bistramide A.

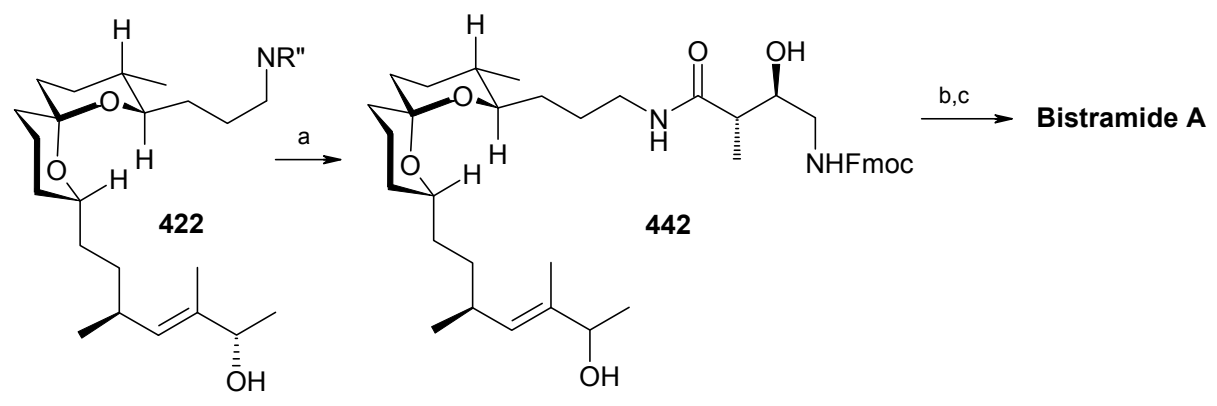

Reagents and conditions: (a) 423, PyBOP, DMF, 85\%; (b) Et 3 N, DMF; (c) 424, DMF, $20{ }^{\circ} \mathrm{C}$.

The amino acid fragment $\mathbf{4 2 3}$ is prepared in five steps starting with Brown crotylboration of aldehyde 436 as shown in Scheme 98 [176]. Similarly, synthesis of pyran fragment 424 starts with the Brown crotylboration of aldehyde $\mathbf{4 3 7}$, followed by acylation with acryloyl chloride to give diene $\mathbf{4 3 8}$ (Scheme 99). Ring closing-metathesis followed by hydrogenation affords lactone 439, which is converted to lactol by DIBALH reduction and then to acetate. The resulting acetate is converted to $C$ glycoside after reaction with silyl dienol ether $\mathbf{4 4 0}$ to give desired enone $\mathbf{4 4 1}$ with good efficiency and diastereoselectivity ( $d r:$ 92:8). The enone $\mathbf{4 4 1}$ is then converted to desired fragment $\mathbf{4 2 4}$ in three steps. Finally, the coupling of three fragments $\mathbf{4 2 2}, \mathbf{4 2 3}$, and $\mathbf{4 2 4}$ affords bistramide A as shown in Scheme 100. It starts with PyBOP-mediated condensation of primary amine $\mathbf{4 2 2}$ with Fmoc-protected amino acid fragment $\mathbf{4 2 3}$ to give $\mathbf{4 4 2}$, which on deprotection of Fmoc, followed by reaction with fragment 424 affords the target.

\subsubsection{Crimmins Synthesis}

Crimmins et al. have reported a convergent, enatioselective total synthesis of bistramide A [177]. In this approach the molecule is disconnected into three fragments: pyran 443, carboxylic acid 444 and spiroketal fragment 445 (Scheme 101).

Scheme 101. Retrosynthetic analysis bistramide A.

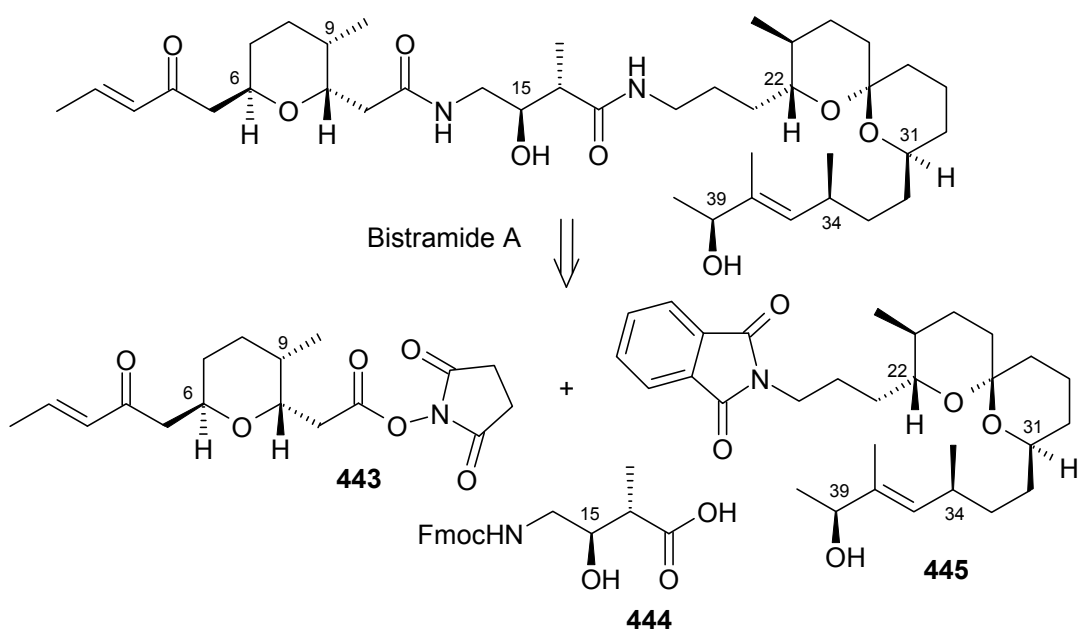


The synthesis of pyran fragment starts with aldehyde 446, which on aldol condensation with chlorotitanium enolate of $\mathrm{N}$-propionyl thiazolidinethione 447 affords aldol product 448 with excellent diastereoselectivity (98:2 dr) [178]. Removal of chiral auxiliary followed by Wittig reaction gives ester 449. Hydrogenation of olefin and subsequent lactonisation followed by reductive acetylation yields acetate $\mathbf{4 5 0}$ as a mixture of anomers (7:1). The acetate $\mathbf{4 5 0}$ is converted to pyran fragment $\mathbf{4 4 3}$ in four steps (Scheme 102).

Scheme 102. Synthesis of pyran fragment 443.

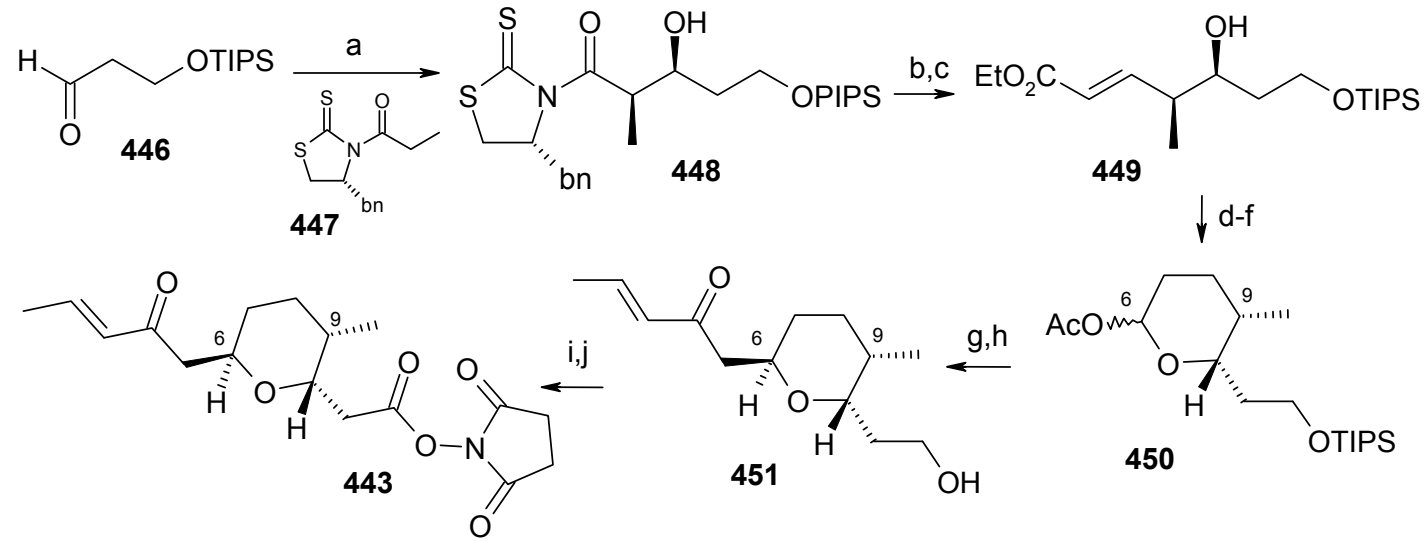

Reagents and conditions: (a) $\mathrm{TiCl}_{4}$, NMP, (-)-sparteine, $\mathrm{CH}_{2} \mathrm{Cl}_{2},-78{ }^{\circ} \mathrm{C}, 447,87 \%$, (b) $i-\mathrm{Bu}_{2} \mathrm{AlH}$, THF, -78 ${ }^{\circ} \mathrm{C}$, (c) $\mathrm{Ph}_{3} \mathrm{P}=\mathrm{CHCO}_{2} \mathrm{Et}, \mathrm{CH}_{2} \mathrm{Cl}_{2}, 78 \%$, (d) $\mathrm{H}_{2}$, Raney Ni, EtOH, (e) PPTS, $\mathrm{CH}_{2} \mathrm{Cl}_{2}, 40{ }^{\circ} \mathrm{C}, 81 \%$, (f) $i-\mathrm{Bu}_{2} \mathrm{AlH}$, Py, DMAP, $\mathrm{Ac}_{2} \mathrm{O}, \mathrm{CH}_{2} \mathrm{Cl}_{2},-78$ to $-20{ }^{\circ} \mathrm{C} 96 \%$, (g) Et $3 \mathrm{~N}$, TMSOTf, 3-penten-2-one, $\mathrm{CH}_{2} \mathrm{Cl}_{2}, 0{ }^{\circ} \mathrm{C}$, then 78 ${ }^{\circ} \mathrm{C}$, then acetate $450,87 \%, 9: 1 \mathrm{dr}$, (h) $\mathrm{H}_{2} \mathrm{SiF}_{6}, \mathrm{MeCN}, 0{ }^{\circ} \mathrm{C}, 75 \%$, (i) $\mathrm{H}_{5} \mathrm{IO}_{6} / \mathrm{CrO}_{3}, \mathrm{MeCN}, 77 \%$, (j) $\mathrm{N}$ hydroxysuccinimide, EDC. $\mathrm{HCl}, \mathrm{CH}_{2} \mathrm{Cl}_{2}, 100 \%$.

Preparation of carboxylic acid fragment 444 starts with allyl alcohol $\mathbf{4 5 2}$. Sharpless epoxidation of 452 followed by treatment with lithium dimethylcuprate affords 1,3-diol 453 along with the unwanted 1,2-diol in a ratio of $6: 1$.

Scheme 103. Synthesis of carboxylic acid fragment 444.

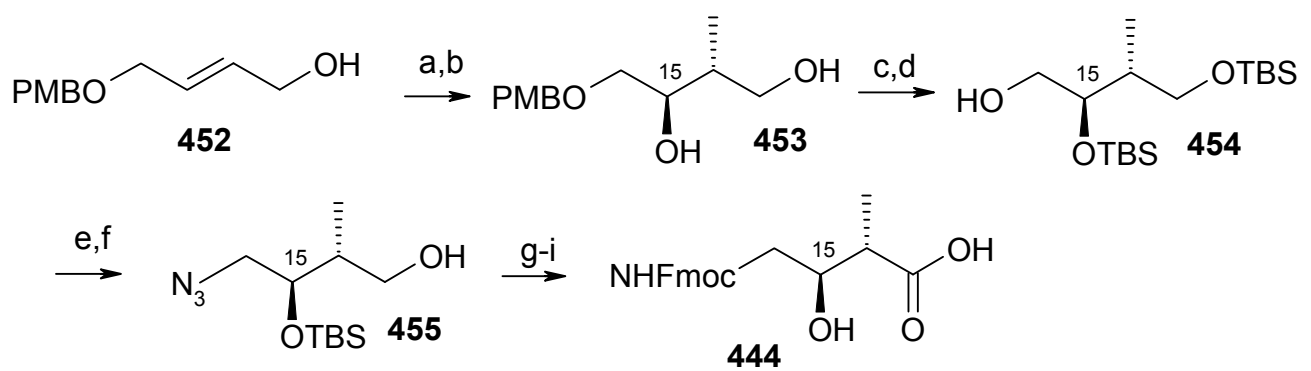

Reagents and conditions: (a) L-(+)-DET, Ti(Oi-Pr) $)_{4}, t-\mathrm{BuOOH}, \mathrm{CH}_{2} \mathrm{Cl}_{2}, \mathrm{MS} 4 \mathrm{~A},-20{ }^{\circ} \mathrm{C}, 95 \%, 98 \%$ ee, (b) $\mathrm{Me}_{2} \mathrm{CuLi}, \mathrm{Et}_{2} \mathrm{O},-50$ to $25^{\circ} \mathrm{C}, 6: 1$ of 1,3- to 1,2-diol; $\mathrm{NaIO}_{4}, \mathrm{H}_{2} \mathrm{O}, 71 \%$, (c) TBSOTf, 2,6-lutidine, $\mathrm{CH}_{2} \mathrm{Cl}_{2}, 0$ ${ }^{\circ} \mathrm{C}, 97 \%$, (d) DDQ, pH 7 buffer, $\mathrm{CH}_{2} \mathrm{Cl}_{2}, 0{ }^{\circ} \mathrm{C}, 98 \%$, (e) DEAD, $\mathrm{Ph}_{3} \mathrm{P},(\mathrm{PhO})_{2} \mathrm{PON}_{3}, \mathrm{THF}, 0{ }^{\circ} \mathrm{C}, 90 \%$, (f) $\mathrm{CSA}, \mathrm{MeOH}, \mathrm{CH}_{2} \mathrm{Cl}_{2},{ }^{\circ} \mathrm{C}, 85 \%$, (g) Pd/C, Fmoc-Osu, THF, 70\%. 
The minor 1,2-diol is removed by treating the mixture with sodium metaperiodate to give 1,3-diol 453. The diol $\mathbf{4 5 3}$ is converted to $\mathbf{4 5 4}$ in a two-step protection/deprotection sequence. Mitsunobu reaction with diphenylphosphoryl azide converted compound $\mathbf{4 5 4}$ to an azide, which on reaction with CSA affords alcohol 455. Oxidation of primary alcohol, deprotection of TBS ether and reduction of azide to amine followed by in situ acylation gives carboxylic fragment 444 (Scheme 103).

Synthesis of spiroketal fragment starts with the asymmetric glycolate alkylation of sodium enolate of amide 456 with allyl iodide to give allylated acyl oxazolidinone, which after removal of chiral auxiliary followed by oxidation of the resulting primary alcohol under Swern condition affords aldehyde 457. Modified Julia olefination of the aldehyde 457 with sulfone 458 yields diene 459 as a mixture (60:40) [36]. Diene 459 is subjected to a cross metathesis reaction with methyl acrylate to give unsaturated methyl ester, which on hydrogenation followed by acidification yields lactone $\mathbf{4 6 0}$. Lactone 460 on treatment with lithiated alkyne 461 affords keto alcohol, which on hydrogenation with hydrogen in presence of palladium yields trihydroxy alcohol, which immediately cyclised to give spiroketal 462.

Scheme 104. Synthesis of spiroketal fragment 445.

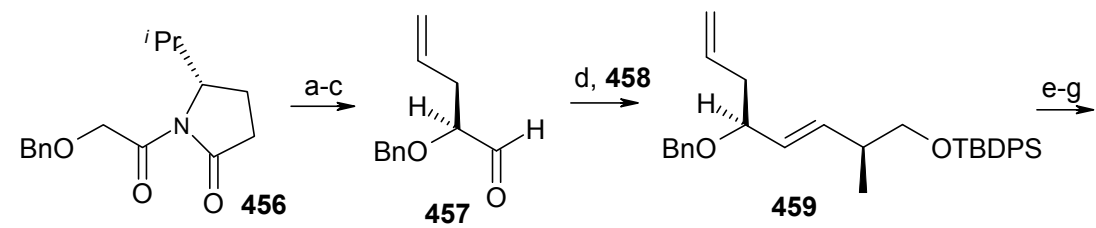<smiles>CC(CCC1CCCC(=O)O1)C[O+]Sc1ccccc1</smiles><smiles>CC(C)COC(C)CC[C@H]1CCC[C@@]2(CCC(C)[C@@H](CCCO)O2)O1</smiles>

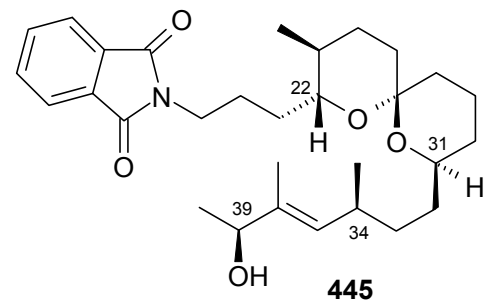

462

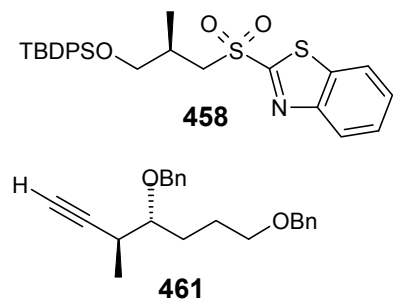

Reagents and conditions: (a) NaHMDS, allyl iodide, THF, toluene, -78 to $-45^{\circ} \mathrm{C}, 81 \%$, (b) $\mathrm{LiBH}_{4}, \mathrm{MeOH}$ $\mathrm{Et}_{2} \mathrm{O}, 98 \%$, (c) $\mathrm{Et}_{3} \mathrm{~N}$, DMSO, $(\mathrm{COCl})_{2}, \mathrm{CH}_{2} \mathrm{Cl}_{2},-78$ to $-25{ }^{\circ} \mathrm{C}, 98 \%$, (d) LiHMDS, THF, sulfone $458,-78$ to $-20{ }^{\circ} \mathrm{C}, 87 \%$, (e) $\mathrm{Cl}_{2}\left(\mathrm{Cy}_{3} \mathrm{P}\right)$ (Imes) $\mathrm{Ru}=\mathrm{CHPh}$, methyl acrylate, $\mathrm{CH}_{2} \mathrm{Cl}_{2}, 40{ }^{\circ} \mathrm{C}, 87 \%$, (f) $\mathrm{H}_{2}, \mathrm{Pd} / \mathrm{C}, \mathrm{EtOAc},(\mathrm{g})$ p-TSA, benzene, $80{ }^{\circ} \mathrm{C}, 70 \%$, (h) alkyne 461, $n$-BuLi, $-78{ }^{\circ} \mathrm{C}$, (i) $\mathrm{H}_{2}, \mathrm{Pd} / \mathrm{C}, \mathrm{MeOH}, \mathrm{EtOAc}, 83 \%,(\mathrm{j}) \mathrm{Ph}_{3} \mathrm{P}$, DEAD, phthalimide, THF, $0{ }^{\circ} \mathrm{C}$, (k) HF.Py., THF, 84\%, (l) Dess-Martin periodinane, $\mathrm{CH}_{2} \mathrm{Cl}_{2}, \mathrm{Py} .92 \%$, (m) $\mathrm{Ba}(\mathrm{OH})_{2}, \mathrm{THF}, \mathrm{MeCOCH}(\mathrm{Me}) \mathrm{P}(\mathrm{O})(\mathrm{OEt})_{2}, 58 \%$, (n) $(R)$-CBS, catecholborane, toluene, $-78{ }^{\circ} \mathrm{C}, 65 \%, 98: 2$ dr.

The spiroketal 462 is then converted under Mitsunobu conditions to its phthalimide derivative, which after TBDPS deprotection gives an alcohol (Scheme 104). Oxidation of the alcohol to an aldehyde followed by Horner-Wadsworth-Emmons olefination installs the $E$-olefin. The 
stereoselective reduction of ketone by Corey's oxazoborolidine affords spiroketal fragment 445 with desired C-39 stereochemistry [175]. Finally, the condensation of three units $\mathbf{4 4 3}, \mathbf{4 4 4}$ and 445 affords bistramide A. Removal of phthalidide group from 445 by methylamine, PyBOP-mediated condensation with acid 444, affords amide 463. Deprotection of Fmoc group and then treatment with ester $\mathbf{4 4 3}$ establishes the final structure (Scheme 105).

Scheme 105. Total synthesis of bistramide A.

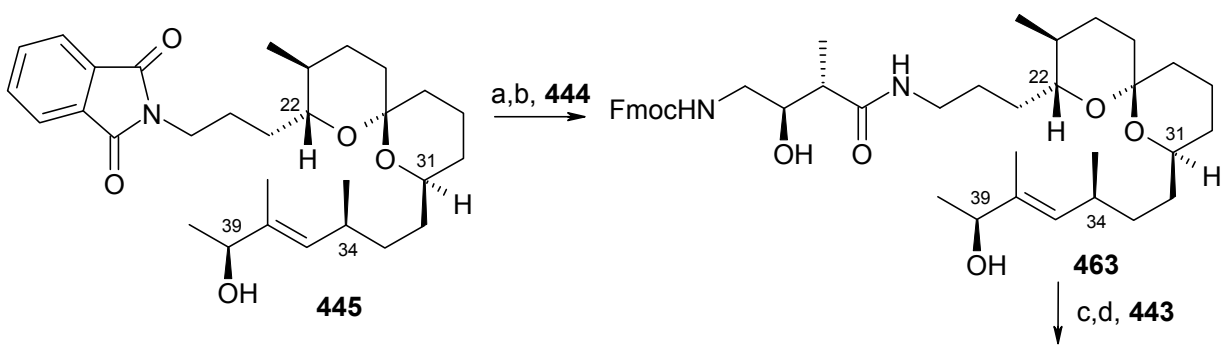

Bistramide A

Reagents and conditions: (a) $\mathrm{MeOH}, \mathrm{MeNH}_{2}, 65^{\circ} \mathrm{C}$, (b) PyBOP, 444, DIEA, DMF, $88 \%$, (c) $\mathrm{Et}_{2} \mathrm{NH}, \mathrm{DMF}$,

(d) 443 , DMF, $82 \%$.

\subsubsection{Panek Synthesis}

Panek et al. have reported a total synthesis of bistramide A using three different organosilane reagents [179]. The retrosynthetic analysis of the molecule is shown in Scheme 106.

Scheme 106. Retrosynthetic analysis of bistramide A.
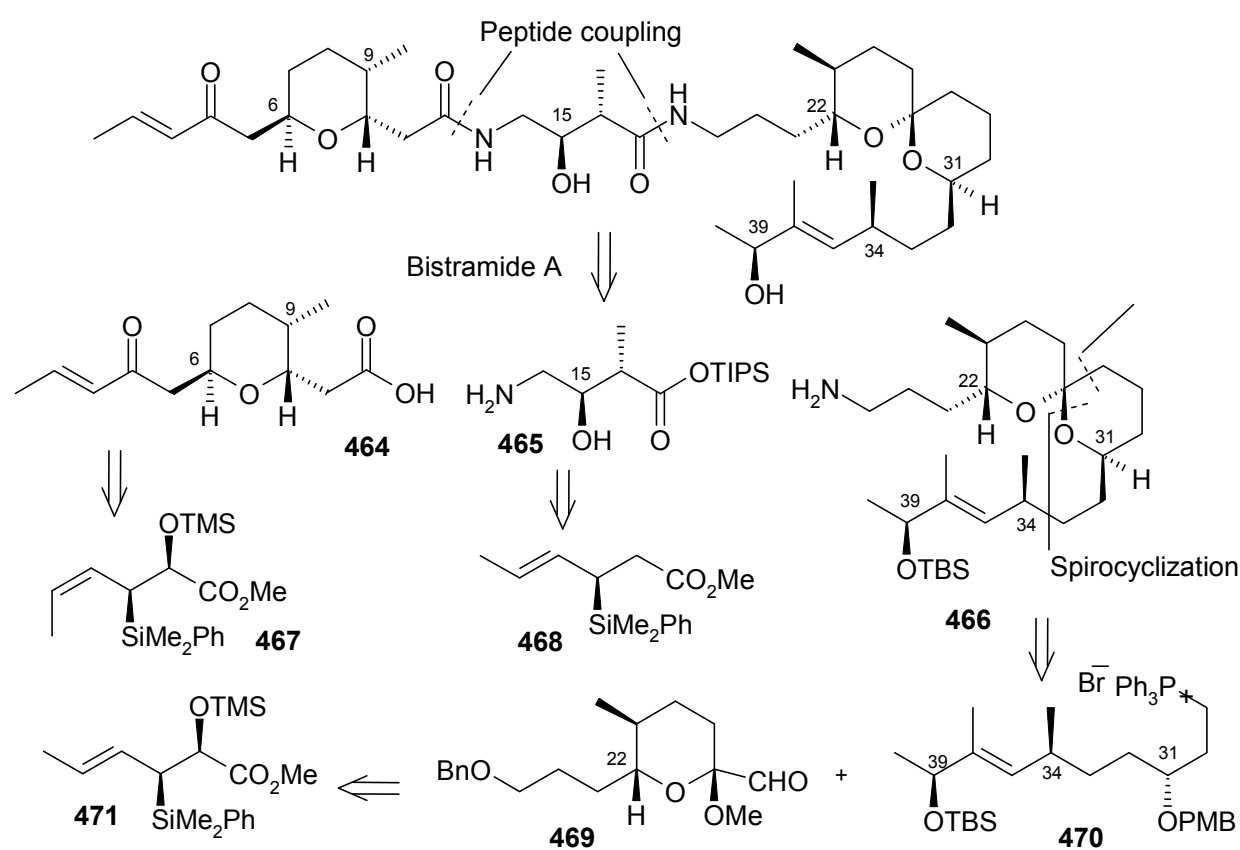

It reveals that three units, pyran 464, $\gamma$-amino acid 465 and spiroketal 466 constitute the molecule. Pyran unit 464 can be prepared from (Z)-crotylsilane reagent 467, whereas the $\gamma$-amino acid 465 can be obtained from $(R)$-silane reagent 468. On the other hand the spiroketal unit can be accessible from 
pyran 469 and phosphonium salt 470. Tetrahydropyran 469 in turn can be obtained from crotyl silane 471.

The $\gamma$-amino acid 465 is prepared starting from known homoallylic alcohol 472 (Scheme 107). Protection of alcohol as its silyl ether, ozonolysis followed by reduction/protection affords alcohol 473. Deprotection of benzyl ether and then azide formation followed by selective silyl ether deprotection affords the desired alcohol 474, which after oxidation/protection and reduction sequence gives the $\gamma$-amino acid $\mathbf{4 6 5}$.

Scheme 107. Synthesis of $\gamma$-amino acid fragment 465.

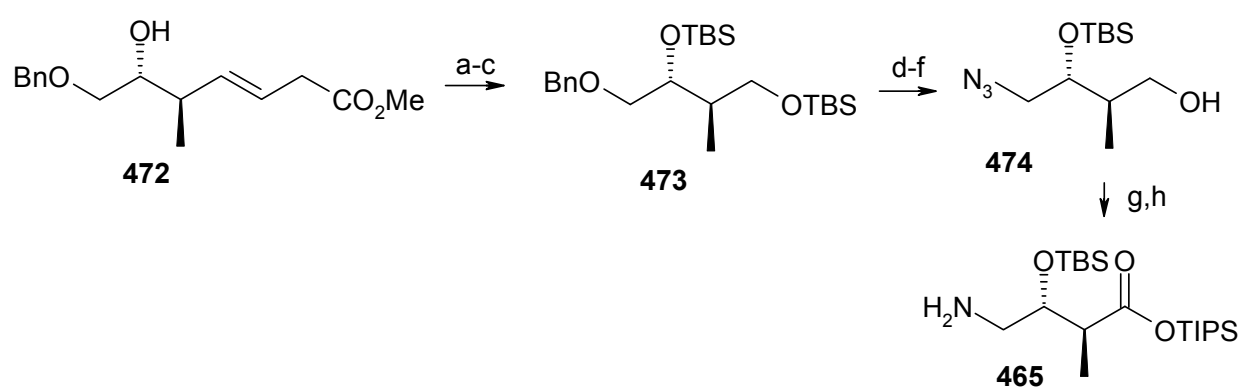

Reagents and conditions: (a) TBSOTf, 2,6-lutidine, $\mathrm{CH}_{2} \mathrm{Cl}_{2}, 99 \%$, (b) $\mathrm{O}_{3}, \mathrm{MeOH}, \mathrm{Py}, \mathrm{NaBH}_{4}, 92 \%$, (c) TBSCl, imidazole, DMF 99\%, (d) $\mathrm{H}_{2}$, Pd/C, EtOAc, 84\%, (e) $\mathrm{Ph}_{3} \mathrm{P}$, DIAD, THF, $\left(\mathrm{C}_{6} \mathrm{H}_{5} \mathrm{O}\right)_{2} \mathrm{P}(\mathrm{O}) \mathrm{N}_{3}, 93 \%$, (f) CSA, $\mathrm{MeOH}, \mathrm{CH}_{2} \mathrm{Cl}_{2}, 90 \%$, (g) (i) $\mathrm{NaOCl}, \mathrm{NaClO}_{2}$, TEMPO, (ii) TIPSCl, $\mathrm{CH}_{2} \mathrm{Cl}_{2}, \mathrm{Et}_{3} \mathrm{~N}, 76 \%$, (h) $\mathrm{H}_{2}, \mathrm{Pd} / \mathrm{C}$, THF.

Synthesis of fragment $\mathbf{4 7 0}$ begins with $\mathbf{4 7 5}$ obtained from $(S)$-1,2,3-butanetriol. Wittig reaction followed by reduction of olefin and deprotection of benzyl ether with Raney nickel affords a primary alcohol, which upon oxidation under Swern condition affords the aldehyde. The resulting aldehyde is then converted to $\alpha, \beta$-unsaturated ketone $\mathbf{4 7 8}$.

Scheme 108. Synthesis of phosphonium salt fragment 470.
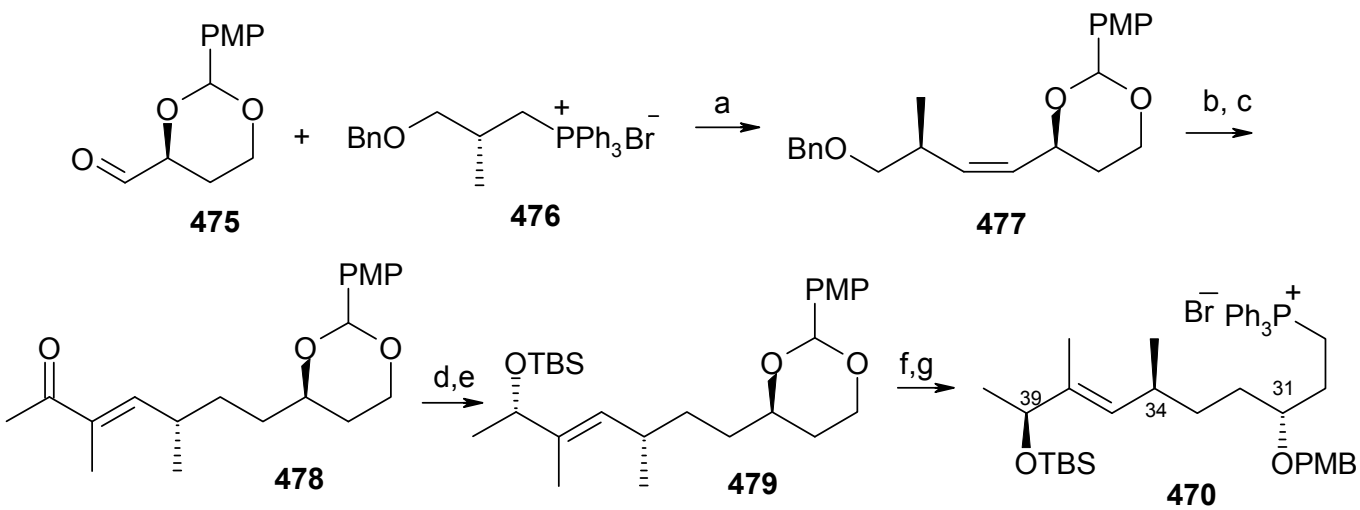

Reactions and conditions: (a) $n$-BuLi, THF, $0{ }^{\circ} \mathrm{C}, 70 \%,\left(E: Z=10: 1\right.$, (b) $\mathrm{H}_{2}$, Raney $\mathrm{Ni}, \mathrm{EtOH}, 78 \%$, (c) (i) $(\mathrm{COCl})_{2}, \mathrm{DMSO}, \mathrm{Et}_{3} \mathrm{~N}, \mathrm{CH}_{2} \mathrm{Cl}_{2}$, (ii) $\mathrm{MeCOCH}(\mathrm{Me}) \mathrm{P}(\mathrm{O})(\mathrm{OEt})_{2}, \mathrm{Ba}(\mathrm{OH})_{2}, \mathrm{THF}, 63 \%$, (d) $(R)-\mathrm{CBS}$, catecholborane, toluene, 88\%, (e) TBSOTf, 2,6-lutidine, $\mathrm{CH}_{2} \mathrm{Cl}_{2}, 86 \%$, (f) DIBALH, THF, 98\%, (g) $\mathrm{CBr}_{4}$, $\mathrm{Ph}_{3} \mathrm{P}, 2$,6-lutidine, $\mathrm{CH}_{2} \mathrm{Cl}_{2}, 97 \%$, (g) $\mathrm{Ph}_{3} \mathrm{P}, 2$,6-lutidine, $\mathrm{MeCN}, 96 \%$. 
The ketone is then reduced to alcohol using Corey's chiral oxazaborolidine and protected as a TBS ether to give 479, which is converted to phosphonium salt 470 in three steps (Scheme 108) [163]. Synthesis of spiroketal unit 466 is starts with [4+2] cycloaddition of syn-(E)-crotylsilane 471 with aldehyde 480 to give endocyclic dihydropyran 481 , which is isomerised to conjugated dihydropyran 482 using tetrabutylammonium hydroxide [180,181]. The dihydropyran $\mathbf{4 8 2}$ is converted to its methyl glycoside and then to aldehyde 469. Olefination of aldehyde 469 with phosphonium salt 470 affords $(Z)$-alkene 483 as a single isomer. Selective reduction of C28-C29 olefin of 483 followed by deprotection of PMB ether under DDQ conditions affords spiroketal 484 without formation of 485. Deprotection of benzyl ether followed by conversion of alcohol to azide and subsequent amine formation affords the spiroketal fragment 466 (Scheme 109).

Scheme 109. Synthesis of spiroketal fragment 466.
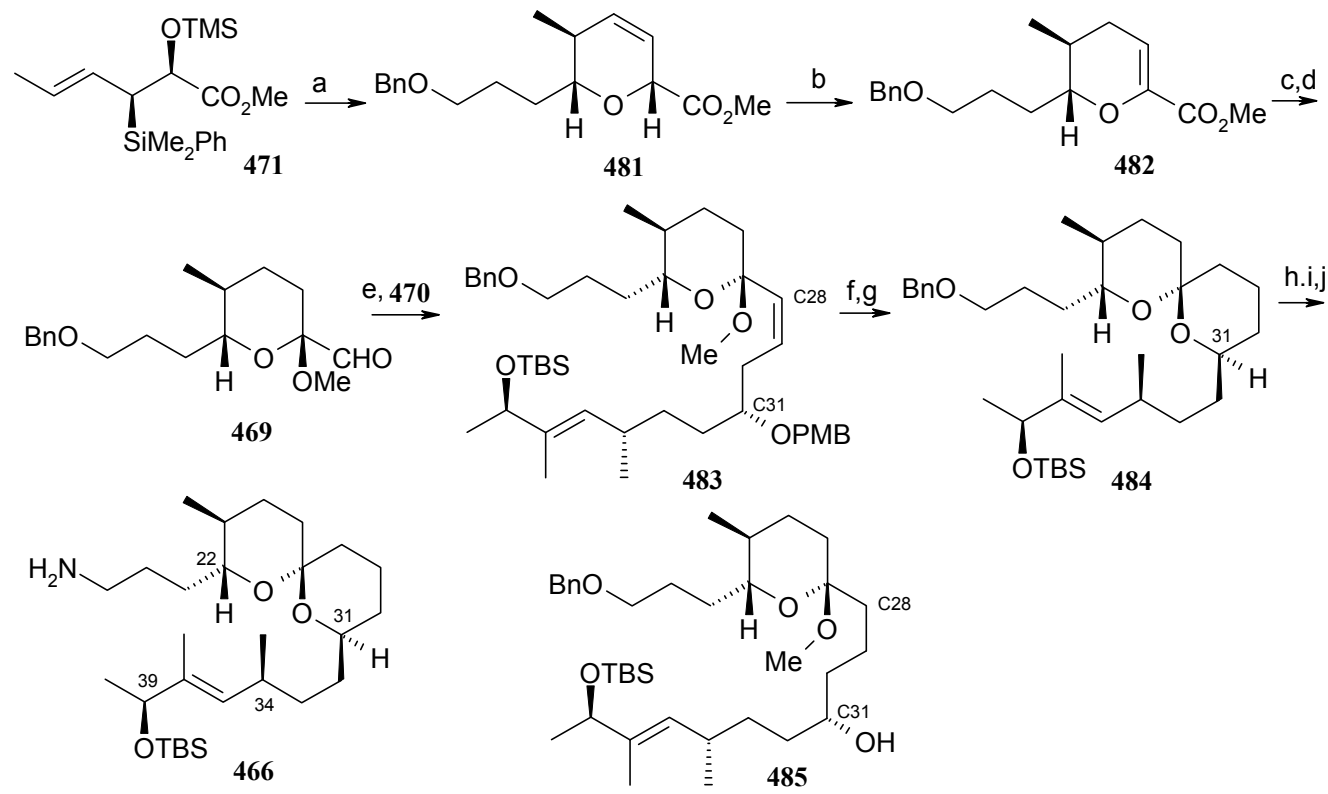

Reagents and conditions: (a) TMSOTf, $\mathrm{CH}_{2} \mathrm{Cl}_{2}, \mathrm{BnO}\left(\mathrm{CH}_{2}\right)_{3} \mathrm{CHO}, 480,-50{ }^{\circ} \mathrm{C}, 97 \%, \mathrm{dr}=20: 1$; (b) $n$ $\mathrm{Bu}_{4} \mathrm{NOH}$, THF, $96 \%$; (c) CSA, MeOH, $81 \%$, (d) DIBALH, $\mathrm{Et}_{2} \mathrm{O}, 94 \%$; (e) $n$-BuLi, 470, THF, $0{ }^{\circ} \mathrm{C}, 86 \%$; (f) $\left(\mathrm{Ph}_{3} \mathrm{P}\right)_{3} \mathrm{RhCl}$, benzene, $75 \%$; (g) $\mathrm{Ph}_{3} \mathrm{P}$, DIAD, $\left(\mathrm{C}_{6} \mathrm{H}_{5} \mathrm{O}\right)_{2} \mathrm{P}(\mathrm{O}) \mathrm{N}_{3}$, THF, 86\%; (h) $\mathrm{PMe}_{3}, \mathrm{THF}, \mathrm{H}_{2} \mathrm{O}$.

Scheme 110. Total synthesis of bistramide A.

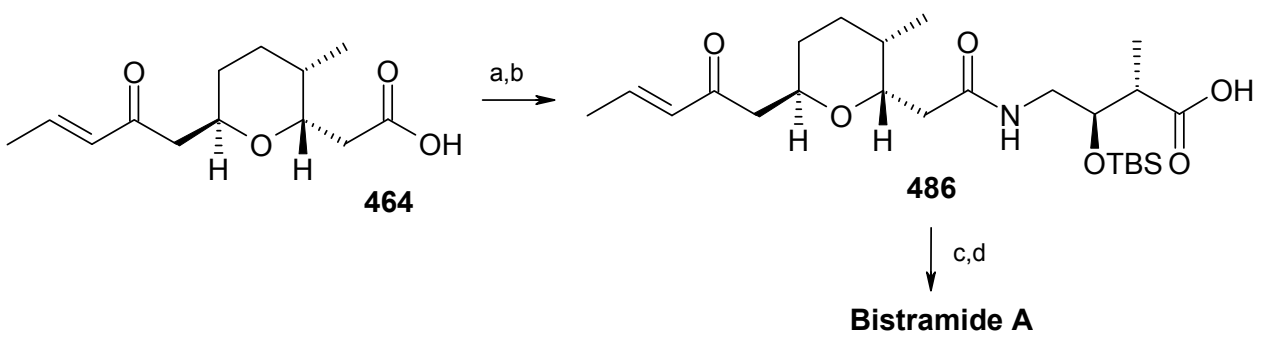

Reagents and conditions: (a) PyBOP, $\mathrm{Et}_{3} \mathrm{~N}, \mathrm{CH}_{2} \mathrm{Cl}_{2}, 465,61 \%$; (b) TBAF, THF, 92\%; (c) PyBOP, DIPEA, DMF, 466, 72\%; (d) PPTS, MeOH, 61\%. 
Finally the three units 464, $\mathbf{4 6 5}$ and $\mathbf{4 6 6}$ are coupled to furnish bistramide A. Coupling of fragments 464 with 465 is effected by the PyBOP peptide coupling reagent. The resulting coupled product is treated with fluoride ion to deprotect the TIPS, which permit the second peptide coupling of acid $\mathbf{4 8 6}$, and amine fragment 466 to give the silyl protected bistramide A (Scheme 110). Deprotection of silyl group affords bistramide A.

Among the four approaches for the synthesis of bistramide A, the Crimmins method is the shortest one. The advantage of this synthesis is that spirocyclisation from a keto alcohol takes place spontaneously in a neutral medium with high yield (83\% in two steps). Similarly in the Kozmin synthesis the spirocyclisation from a keto alcohol also takes place spontaneously in a neutral media affording single diastereomer with good yield (53\% in two steps). The Yadav group constructed the spiroketal unit by hydrolysis of dialkylated tosylmethyl isocyanide derivative derived via alkylation of TosMIC with suitably substituted halohydrin derivatives ( $85 \%$ yield). Panek, on the other hand utilizes the oxidative spirocyclisation for the construction of spiroketal unit with good yield (76\%).

\subsection{Asymmetric Total Synthesis of (-)-Spirofungin A and (+)-Spirofungin B}

Spirofungins A and B are novel polyketide-type antifungal antibiotics isolated from Streptomyces Violaceusniger [182]. Structurally, they are related to reveromycins, antibiotics produced by another Streptomyces strain [183-186].

Scheme 111. The retrosynthetic analysis of (-)-spirofungin A and (+)-spirofungin B.

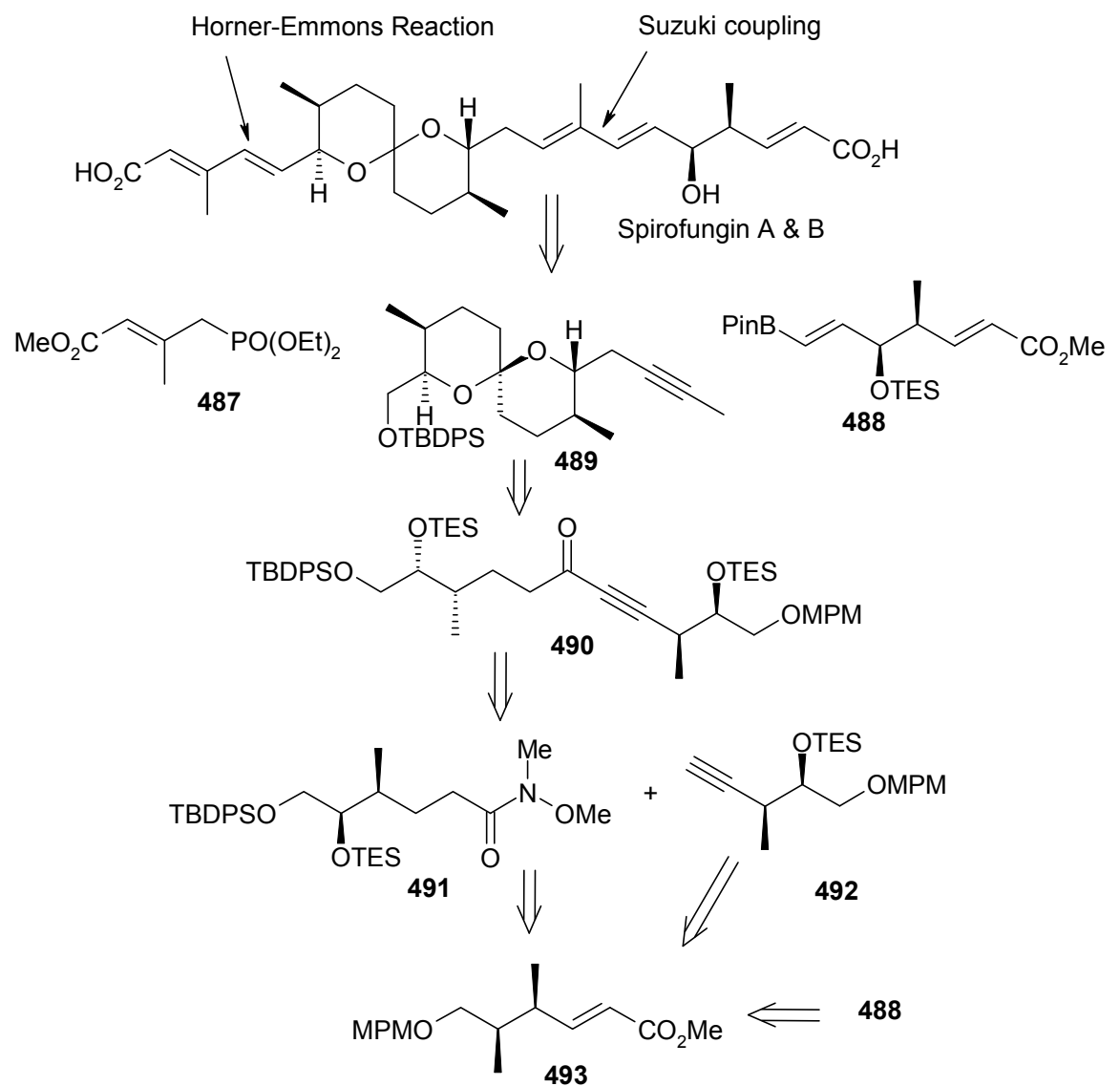


Shimizu and his coworkers have reported the first asymmetric total synthesis of natural spirofungins A and B starting from a common intermediate 493 [187]. The retrosynthetic analysis of the molecule reveals that the left and right side chain can be attached by Horner-Emmons and Suzuki coupling respectively. The spiroketal unit 489 can be obtained from ketone $\mathbf{4 9 0}$, which in turn can be obtained from Weinreb amide 491 and alkyne 492. Both alkyne 492 and amide 491 can be achieved from common intermediate 493 (Scheme 111).

Scheme 112. Synthesis of spiroketals 499 and $\mathbf{5 0 0 .}$

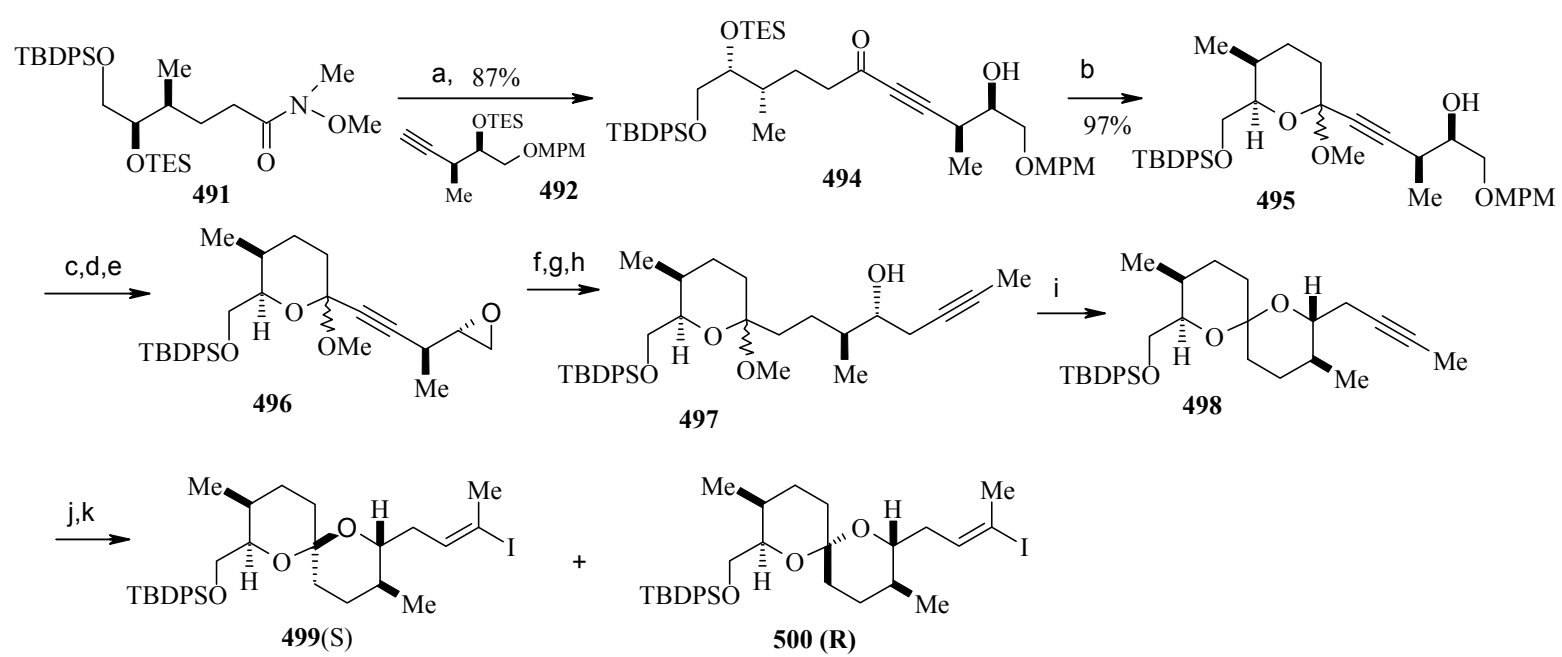

Reagents and conditions: (a) 492, LHMDS, THF, $0{ }^{\circ} \mathrm{C}$ to rt, 87\%; (b) PPTS, MeOH, rt, 97\%; (c) $\mathrm{MsCl}, \mathrm{Py}, 0$ ${ }^{\circ} \mathrm{C}$ to rt, 99\%; (d) DDQ, $\mathrm{CH}_{2} \mathrm{Cl}_{2}-\mathrm{MeOH}$, rt; (e) $\mathrm{K}_{2} \mathrm{CO}_{3}, \mathrm{MeOH}, \mathrm{rt}, 86 \%$; (f) $\mathrm{H}_{2}, \mathrm{Pd} / \mathrm{C}$, EtOAc, rt; (g) PPTS, $\mathrm{MeOH}, \mathrm{rt}, 81 \%$; (h) Propyne, $n$-BuLi, $\mathrm{BF}_{3} \cdot \mathrm{Et}_{2} \mathrm{O}$, THF, $-78{ }^{\circ} \mathrm{C}$; (i) PPTS, $\mathrm{MeOH}, \mathrm{rt}, 93 \%$; (j) $\mathrm{Cp}_{2} \mathrm{ZrHCl}$, benzene, $50{ }^{\circ} \mathrm{C}, \mathrm{I} 2,0{ }^{\circ} \mathrm{C}$; (k) TBAF, THF, rt, $75 \%$.

The synthesis of spiroketal unit is shown in Scheme 112. The Weinreb amide 491 is coupled with lithiated alkyne 492 to give ketone 494. Selective deprotection of TES group by PPTS in methanol furnishes the methyl ketal alkynol 495. Next the alcohol is converted to its mesylate, which is then treated with DDQ to remove MPM. The resulting alcohol on treatment with $\mathrm{K}_{2} \mathrm{CO}_{3}$ provides the epoxide 496 with inversion of configuration at $\mathrm{C}-11$. Hydrogenation of the alkyne followed by reaction with PPTS affords the saturated ketal as a single isomer, which is then converted to alkyne 497 by treating with propyne and $n$-BuLi in the presence of $\mathrm{BF}_{3} . \mathrm{OEt}_{2}$ [188]. Spiroketalization of 497 is achieved by treating with PPTS, which is converted to a mixture of iodides. Deprotection of the resulting iodide affords separable alcohols 499 ( $S$-isomer) and 500 ( $R$-isomer).

Next, the 1-alkenylboronic acid pinacol ester $\mathbf{4 8 8}$ is prepared starting from the common precursor 493 (Scheme 113), whch is silylated with TBSCl, followed by cleavage of the MPM group with DDQ, to afford the alcohol, which is oxidized using Dess-Martin periodinane to provide 501. The aldehyde $\mathbf{5 0 1}$ is converted to iodide $\mathbf{5 0 2}$ as the $(E)$-stereoisomer [189]. The synthesis of $\mathbf{4 8 8}$ from $\mathbf{5 0 2}$ is achieved by palladium catalyzed cross coupling [190]. 
Scheme 113. Synthesis of the 1-alkenylboronic acid pinacol ester 488.

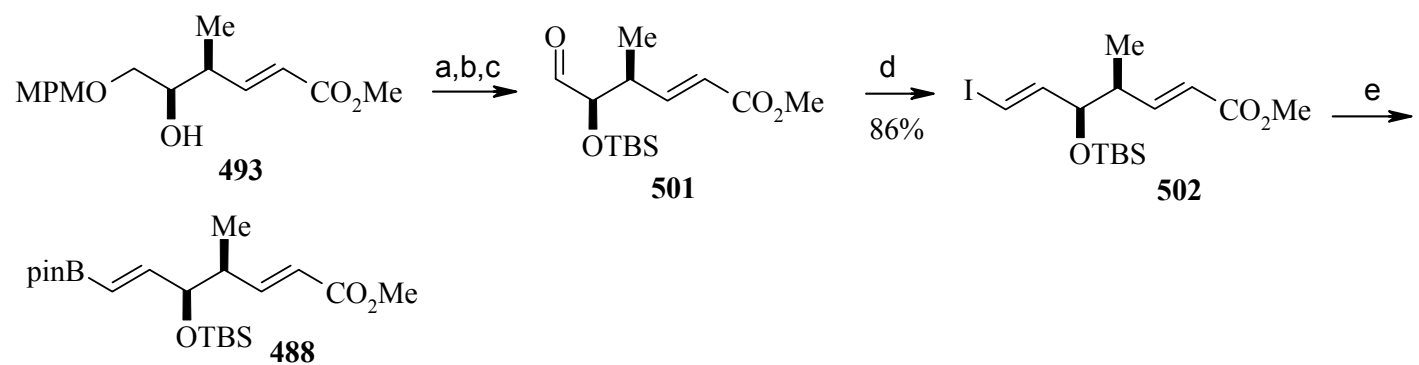

Reagents and conditions: (a) TBSCl, imidazole, DMF, rt; (b) DDQ, $\mathrm{CH}_{2} \mathrm{Cl}_{2}-\mathrm{H}_{2} \mathrm{O}$, rt, 97\%; (c) Dess-Martin periodinane, $\mathrm{CH}_{2} \mathrm{Cl}_{2}, \mathrm{rt}, 98 \%$; (d) $\mathrm{CHI}_{3}, \mathrm{CrCl}_{2}$, THF, $0{ }^{\circ} \mathrm{C}$ to rt, $86 \%$; (e) $\operatorname{pin}_{2} \mathrm{~B}_{2}, \mathrm{KOPh}, \mathrm{PdCl}_{2},\left(\mathrm{PPh}_{3}\right)_{2}$, toluene, $50{ }^{\circ} \mathrm{C}$.

The final total synthesis of spirofungin A and B is shown in Scheme 114. Dess-Martin oxidation of 499 give an aldehyde, which is subjected to the Horner-Emmons reaction with $(\mathrm{EtO})_{2} \mathrm{P}(\mathrm{O}) \mathrm{CH}_{2} \mathrm{C}(\mathrm{Me})=\mathrm{CHCO}_{2} \mathrm{Me}$, to give the desired $(20 E,-22 E)$-dienoic esters 503 [191]. The ester 503 is then condensed with side chain 488 using $\operatorname{Pd}(0)$-mediated diene synthesis developed by Suzuki and co-workers to afford 505, while retaining the original configuration of both $\mathbf{5 0 3}$ and $\mathbf{4 8 8}$. [192].

Scheme 114. Total synthesis of (-)-spirofungin A and (+)-spirofungin B.
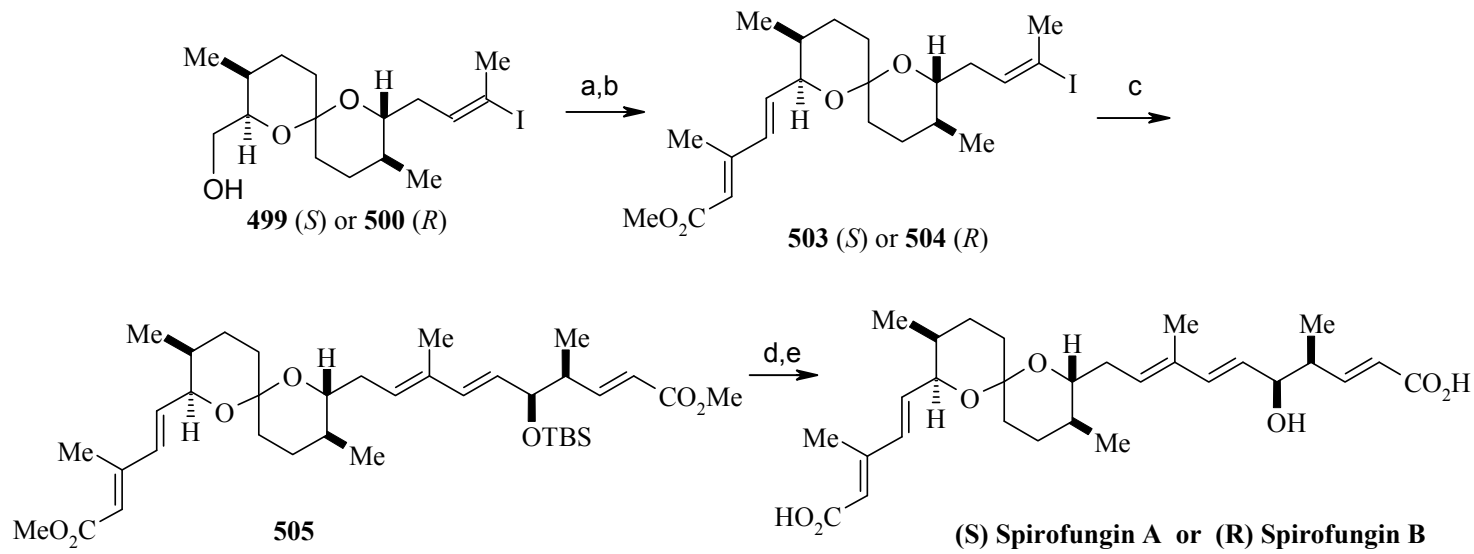

Reagents and conditions: (a) Dess-Martin periodinane, $\mathrm{CH}_{2} \mathrm{Cl}_{2}$, rt; (b) 487, LHMDS, THF-HMPA, $-78{ }^{\circ} \mathrm{C}$; (c) 488, $\mathrm{Pd}\left(\mathrm{PPh}_{3}\right)_{4}, \mathrm{TlOEt}, \mathrm{THF}, \mathrm{rt}$; (d) LiOH, THF-MeOH-H${ }_{2} \mathrm{O}$, rt; (e) TBAF, DMPU, rt.

Hydrolysis of the two-ester groups in $\mathbf{5 0 5}$ with $\mathrm{LiOH}$ in THF-MeOH- $\mathrm{H}_{2} \mathrm{O}$ followed by deprotection of the TBS group with TBAF in DMPU give (-)-spirofungin A. The synthesis of (+)-spirofungin B, is achieved from $\mathbf{5 0 0}$ using the same reaction sequence as spirospongin $\mathrm{A}$. The synthesis is completed in 31 longest linear steps with $7.9 \%$ and $5.2 \%$ overall yield respectively.

\subsection{Total Synthesis of (+)-Calyculin A and (-)-Calyculin B}

Caliculins A and B are naturally occurring spiroketal isolated from the marine Discodermia calyx and potent serine-threonine protein phosphatase (PP1 and PP2A) inhibitors with remarkable cell membrane permeability [193]. Evans, Masamune and Yokokawa reported the synthesis of (+)- 
caliculin A and its antipode (-)-caliculin A [194,195,196]. Amos B. Smith, III, et al. disclosed the total synthesis of (+)-caliculin A and the first total synthesis of (-)-calyculin B in 1998 [197].

The approach is based on a common intermediate, which provide both calyculin A, and B. The retrosynthetic pathway is presented in Scheme 115. Disconnections at the C-2 and C-8 olefins lead to phosphonate 506. Disconnection of 507 at the C-25 olefin reveals substrates 508, which can be obtained from vinyl bromide 510 with epoxide 511, and 509, available from furan 512 and lactam 513 (Scheme 115).

Scheme 115. Retrosynthetic analysis of (+)-calyculin A and (-)-calyculin B.

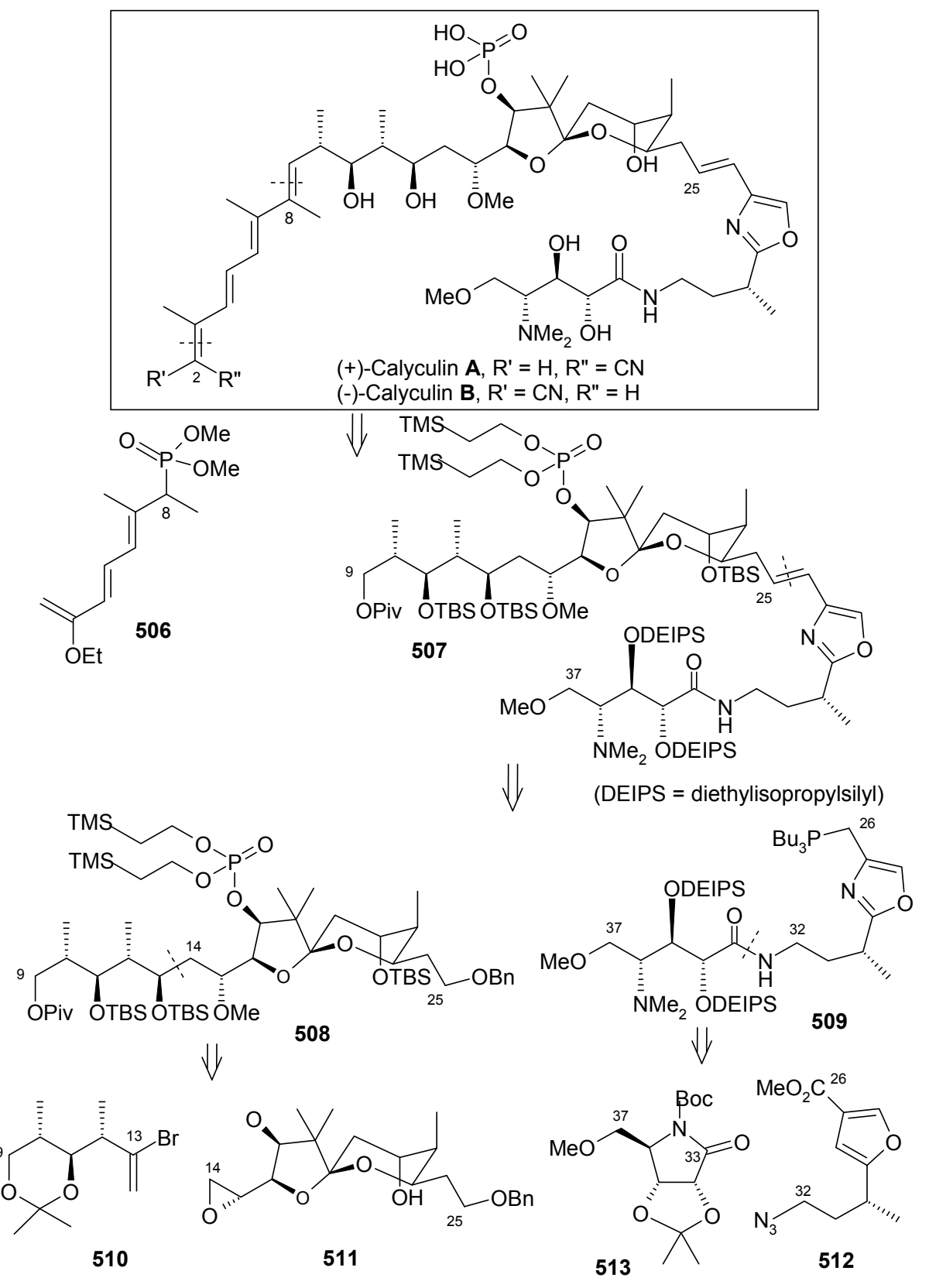


Phosphonate 506 is prepared starting from an organozinc via a Suzuki [198] one-pot-threecomponent triene synthesis (Scheme 116). Thus, Pd-catalyzed coupling of organizinc 514, $(E)$ bromovinyl boronate 515 and vinyl iodide 517 furnishes the desired triene 518, which after methylation affords phosphonate 506 [198].

Scheme 116. Synthesis of phosphonate fragment 506.

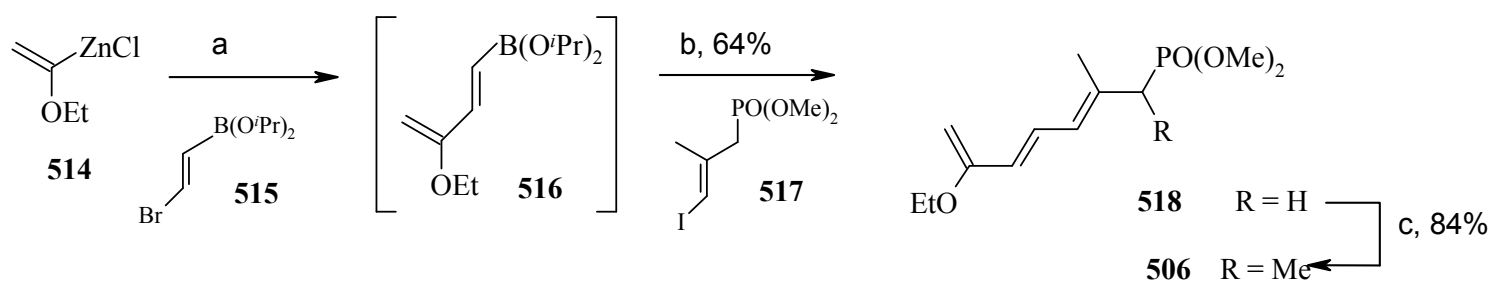

Reagents and conditions: (a) 515, $\mathrm{Pd}\left(\mathrm{Ph}_{3} \mathrm{P}\right)_{4}$; (b) 517, $\mathrm{Ag}_{2} \mathrm{O}, \mathrm{H}_{2} \mathrm{O}$, reflux, 64\%; (c) $n$-BuLi, MeI, $84 \%$.

Synthesis of unit $\mathbf{5 1 0}$ starts with desilylation of the Roush crotylboration product $(+)-\mathbf{5 1 9}$, followed by 1,3-acetonide formation and a modified Wacker oxidation protocol to furnish ketone 520 [199]. The resulting ketone is converted to enol triflate and then reacted with a mixed stannylcuprate, to give stannane which upon bromodestannylation leads to the acyl anion equivalent (+)-510 (Scheme 117) $[200,201]$.

Scheme 117. Synthesis of vinyl bromide fragment 510.

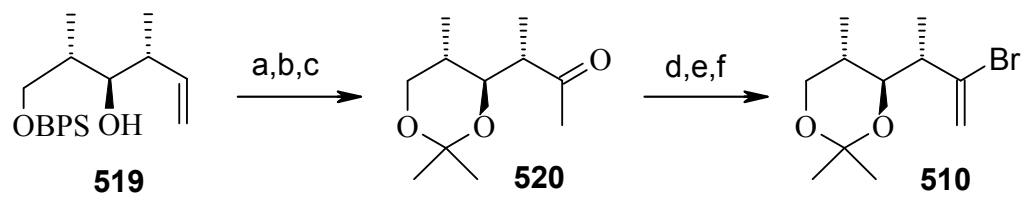

Reagents and conditions: (a) TBAF, THF; (b) $\mathrm{Me}_{2} \mathrm{C}(\mathrm{OMe})_{2}, \mathrm{TsOH}$; (c) $\mathrm{Cu}(\mathrm{OAc})_{2}, \mathrm{PdCl}_{2}, \mathrm{O}_{2}$, aq. $\mathrm{AcNMe}$, $83 \%$; (d) KHMDS, PhNTf 2 , 97\%; (e) (Th)CuCNLi, Bu 3 SnLi, 76\%; (f) NBS, 88\%.

Scheme 118. Synthesis of Wittig reagent 509.

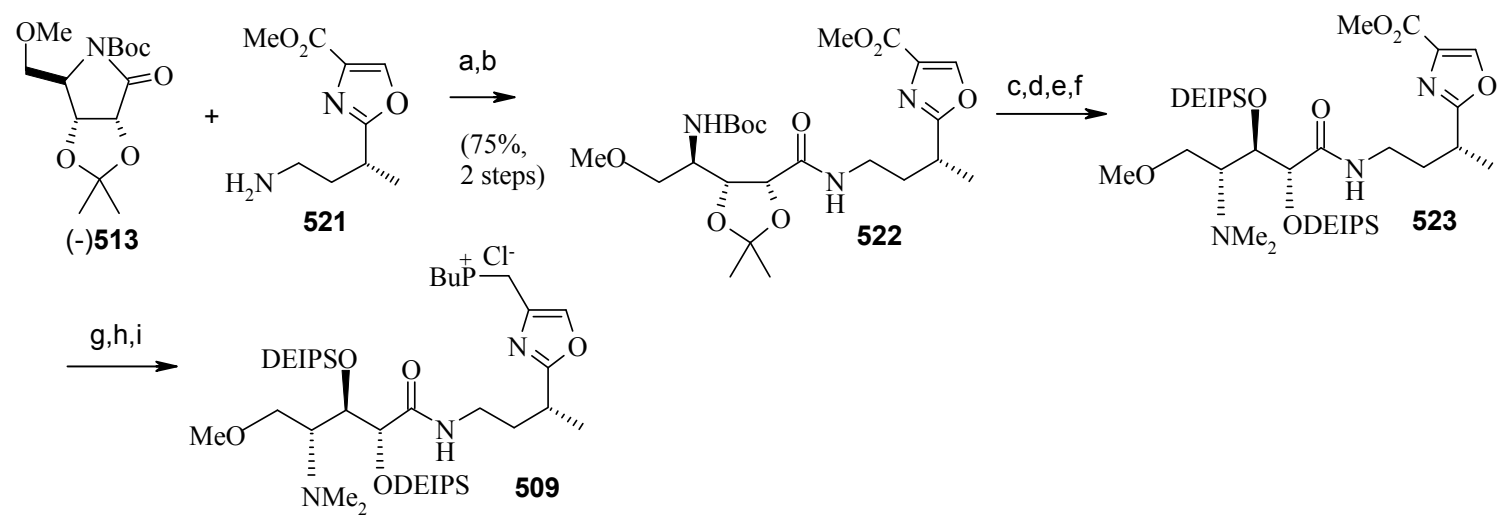

Reagents and conditions: (a) LiOH, $\mathrm{H}_{2} \mathrm{O} / \mathrm{THF}$; (b) DECP, Et ${ }_{3} \mathrm{~N}, \mathbf{5 2 1}$; (c) TMSOTf, 2,6-lutidine; (d) HCHO, $\mathrm{NaBH}_{3} \mathrm{CN}$; (e) $\mathrm{HCl}, \mathrm{MeOH}$; (f) DEIPSOTf, 2,6-lutidine, 50\%, 4 steps; (g) LAH, 89\%; (h) $\mathrm{MsCl}_{2} \mathrm{Et}_{3} \mathrm{~N}$, $\mathrm{BnEt}_{3} \mathrm{NCl}, 79 \%$; (i) $\mathrm{PBu}_{3}, 23{ }^{\circ} \mathrm{C}, \mathrm{MeCN}, \mathrm{THF}, 95 \%$. 
The preparation of the $\mathbf{5 0 9}$ starts with lactam (-)-513. Hydrolysis of lactam (-)-513, [202] and subsequent coupling with amine 521, obtained via Lindlar reduction of azide (-)512, [203] affords amide (+)-522, which on deprotection, reductive methylation of the C-36 amine, and interchange of acetonide group with bis-diethylisopropylsilyl ether affords $(+) \mathbf{5 2 3}$ [204]. Finally $(+)-\mathbf{5 2 3}$ is converted to Wittig reagent $(+)-509$ in three steps, reduction, chlorination and salt formation (Scheme 118).

Scheme 119. Total synthesis of (+)-calyculin A and (-)-calyculin B.
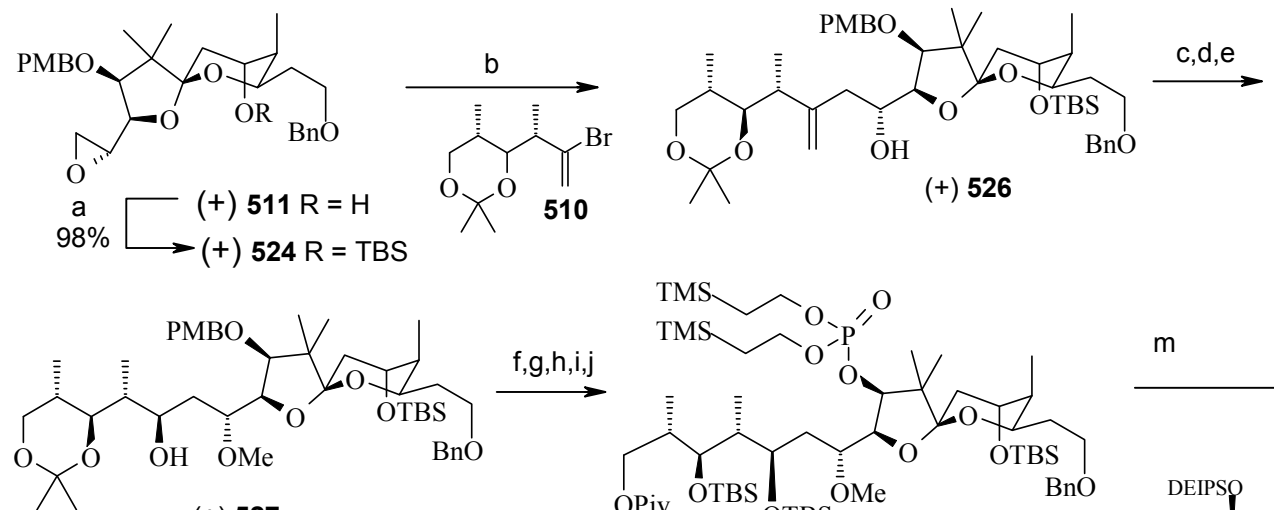

$(+) 527$

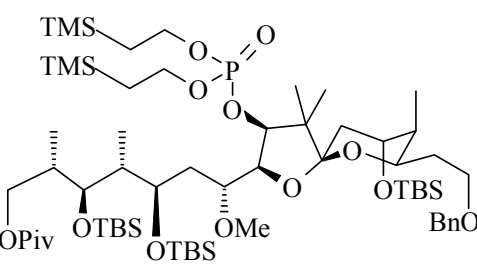

$\mathrm{k}, \mathrm{l}$
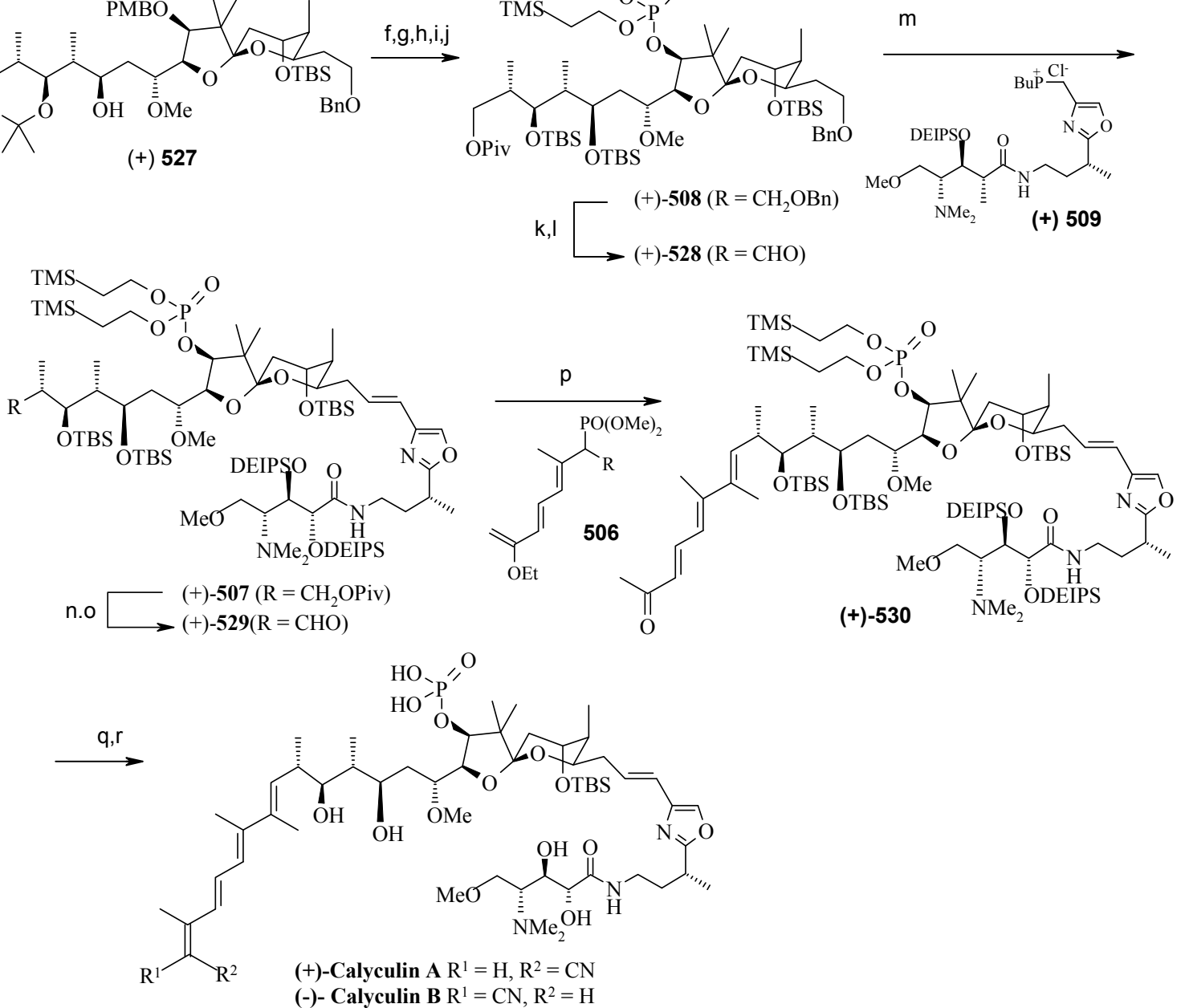

Reagents and conditions: (a) TBSCl, $\mathrm{Et}_{3} \mathrm{~N}, 98 \%$; (b) 510, $t$-BuLi, (Th)CuCNLi, 525, 83\%; (c) KHMDS, MeI, 96\%; (d) $\mathrm{OsO}_{4}, \mathrm{NMO}, \mathrm{NaIO}_{4}, 87 \%$; (e) DIBALH, 84\%; (f) $\mathrm{HO}\left(\mathrm{CH}_{2}\right)_{3} \mathrm{OH}, \mathrm{PPTS}, 64 \%$; (g) PiVCl, Py; (h) TBSOTf, 2,6-lutidine, 93\% in two steps; (i) DDQ, $\mathrm{H}_{2} \mathrm{O}, 92 \%$; (j) $\mathrm{PCl}_{3}$, Py, $\mathrm{TMS}\left(\mathrm{CH}_{2}\right)_{2} \mathrm{OH}, \mathrm{H}_{2} \mathrm{O}_{2}, 91 \%$; (k) $\mathrm{H}_{2}, \mathrm{Pd} / \mathrm{C}$, EtOH; (l) TPAP, NMO, $\mathrm{CH}_{2} \mathrm{Cl}_{2}, 84 \%$; (m) (+)-509, LiHMDS, DMF, $0{ }^{\circ} \mathrm{C}, 83 \%$, 9:1; (n) DIBALH, $-78{ }^{\circ} \mathrm{C}, \mathrm{CH}_{2} \mathrm{Cl}_{2}, 87 \%$; (o) TPAP, NMO, $\mathrm{CH}_{2} \mathrm{Cl}_{2}, 84 \%$; (p) 506, $n$-BuLi, THF, $-78{ }^{\circ} \mathrm{C}, 0.5 \mathrm{~N}$ aq. $\mathrm{HCl}$ workup, $92 \%, 15: 1 \mathrm{E:Z}$ at C-8; (q) $\mathrm{TMSCH}_{2} \mathrm{CN}, n$-BuLi, $-78^{\circ} \mathrm{C}, 1.7: 1 \mathrm{E} / \mathrm{Z}, 94 \%$; ( r) $\mathrm{HF}, \mathrm{MeCN}, \mathrm{H}_{2} \mathrm{O}$. 
Finally, union of all fragments leads to the natural products calyculin A and B (Scheme 119). The unit (+)-511, obtained from Smith's previous work [206], is protected as its corresponding silyl ether $(+)-524$, which is then treated with the vinyl thienylcuprate derived from $\mathbf{5 2 5}$ and $\mathbf{5 1 0}$ to furnish (+)526 [205]. Methylation of the hydroxy group, followed by olefin cleavage and selective reduction of the resulting ketone with DIBALH affords the $\beta$ alcohol (+)-527. Fragment (+)-508 is obtained after protective group exchange, PMB removal and phosphorylation employing the Evans protocol [207].

Hydrogenolysis of $(+)-508$, TPAP oxidation and Wittig olefination with $(+)-509$ provides $(+)-507$ $(E / Z=9: 1)[208,209]$. The pivaloate moiety is removed and the alcohol oxidized to an aldehyde, which is then subjected to Horner-Emmons olefination reaction with phosphonate 506, to furnish trienone (+)-530. Finally Peterson olefination $\left(\mathrm{Me}_{3} \mathrm{SiCH}_{2} \mathrm{CN}, n\right.$-BuLi, $\left.-78{ }^{\circ} \mathrm{C}\right)$ affords protected calyculins $\mathbf{A}$ and $\mathbf{B}$ (1:1.7). Separation of two isomers and treatment with HF acid gives pure calyculin A and caliculin B (Scheme 119).

\subsection{Asymmetric synthesis of spiroacetal 2,2,8-trimethyl-1,7-dioxaspiro[5.5] undecane found in rove} beetles (Ontholestes murinus)

In 1990, Huth and Dettner [210] first reported the presence of 2,2,8-trimethyl-1,7dioxaspiro[5.5] undecane in the defensive secretion of Ontholestes murinus (L.). Kitching and his coworkers have described an asymmetric total synthesis of this compound [211], based on hydrazone alkylation with the $(R)$-iodide 532, followed by an oxymercuration-deprotection-cyclisation sequence as shown in Scheme 120. The hydrazone $\mathbf{5 3 1}$ is first alkylated with iodide $\mathbf{5 3 2}$ to give the (6S,8R)enantiomer 533, which is then treated with silica in hexane-ether to furnish the ketone $\mathbf{5 3 4}$ in good yield (83\%). The compound $\mathbf{5 3 4}$ is first converted to a tertiary alcohol by oxymercuration and then deprotected and finally cyclised to give 2,2,8-trimethyl-1,7-dioxaspiro[5.5] undecane [(6S,8R)-535] (Scheme 120).

Scheme 120. Total synthesis of spiroacetal 2,2,8-trimethyl-1,7-dioxaspiro[5.5] undecane.
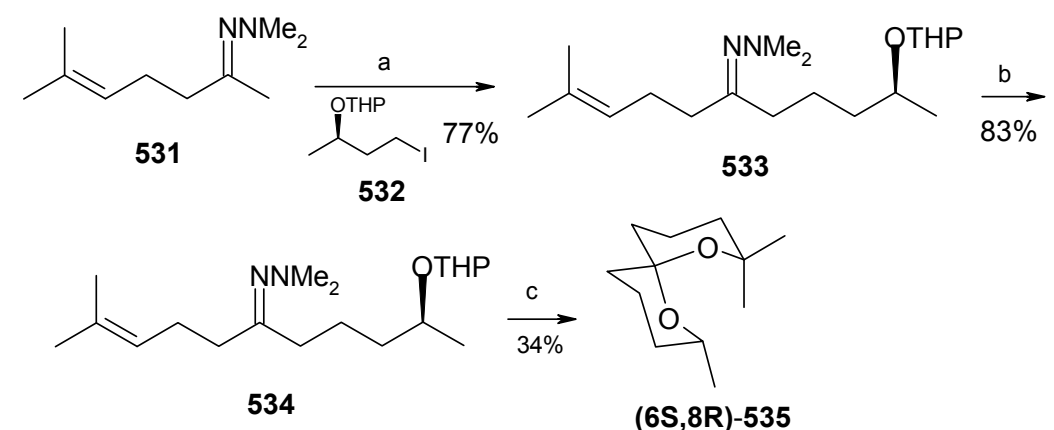

Reagents and conditions: (a) (i) LDA, THF, $-78^{\circ} \mathrm{C}$, (ii) 532, 77\%; (b) (i) $\mathrm{SiO}_{2}$, hexane-ether, $83 \%$; (c) (i) $\mathrm{Hg}(\mathrm{OAc})_{2}$, THF- $\mathrm{H}_{2} \mathrm{O}$, (ii) $\mathrm{BnN}^{+} \mathrm{Et}_{3} \mathrm{Cl}^{-}$. $\mathrm{NaBH}_{4}, \mathrm{NaOH}-\mathrm{H}_{2} \mathrm{O}-\mathrm{CH}_{2} \mathrm{Cl}_{2}, 34 \%$. 


\subsection{Total Synthesis of (+)-Saponaceolide B}

Saponaceolide B was isolated by Bernardi and coworkers from the Northern Italian mushroom Tricholoma saponaceum and it possess antitumor activity in 60 human cancer cell lines [212, 213]. Trost and coworkers first reported the asymmetric synthesis of (+)-saponaceolide B in 1999 [214]. The retrosynthetic analysis is shown in Scheme 121 and it consists of three units 536, $\mathbf{5 3 7}$ and 538. The central unit $\mathbf{5 3 8}$ is crucial in this synthesis, as the cis configuration at C-2 and C-6 is thermodynamically less stable than the corresponding trans one.

Scheme 121. Retrosynthetic analysis of (+)-saponaceolide B.

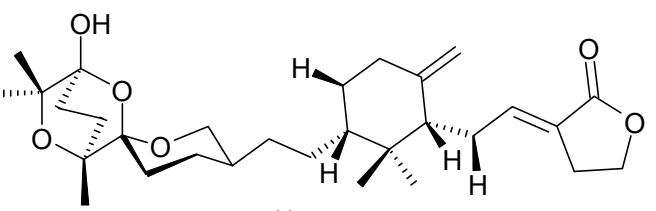

(+)-Saponaceolide B $\Downarrow$

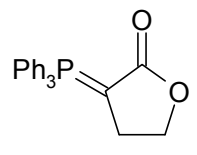

536

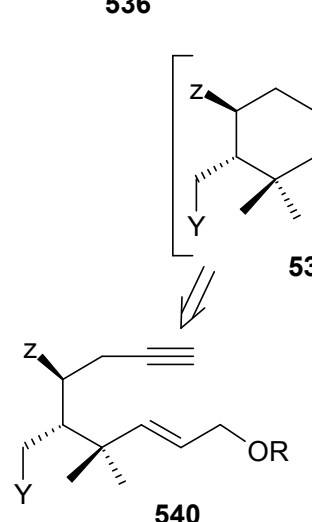

540<smiles>[Y]C[C@H]1[C@@H]([Z])CC(=C)[C@@H](CC=O)C1(C)C</smiles>

$\vee$<smiles>[V]</smiles>

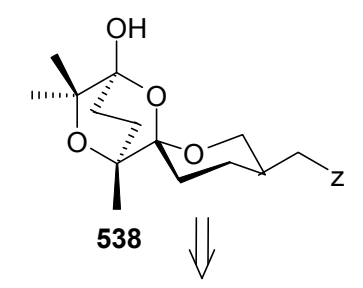<smiles>[R]O[C@H]1CC[C@](C)(C=O)OC1(C)C</smiles>

542

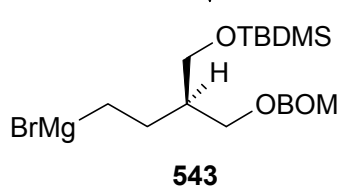

541<smiles>[Y]C[C@H]([C@@H]([Z])CC(=C)Br)C(C)(C)/C=C/CO[R]</smiles>

Synthesis of the spiroketal portion is started with known $(R)$-acetate $\mathbf{5 4 4}$ and known geraniol epoxide (547a). The Grignard reagent 543 is prepared from hydroxy acetate 544. The acetate and hydroxyl group of the compound $\mathbf{5 4 4}$ are transformed into TBDMS and BOM ethers to make the compound compatible for formation of the Grignard reagent 543.

Scheme 122. Synthesis of Grignard reagent 543.

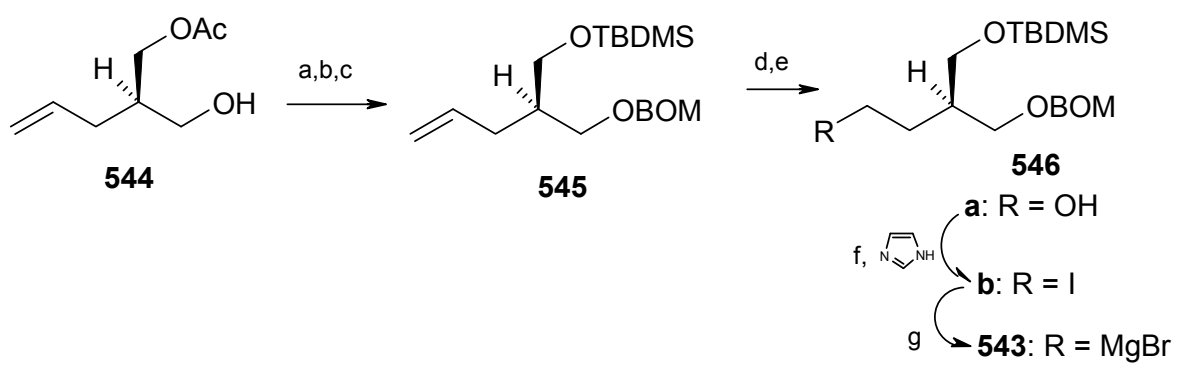

Reagents and conditions: (a) BOMC, $\mathrm{EtN}(i \mathrm{Pr})_{2}, \mathrm{CH}_{2} \mathrm{Cl}_{2}$; (b) $\mathrm{K}_{2} \mathrm{CO}_{3}, \mathrm{MeOH}$; (c) TBDMSCl, $\mathrm{Et}_{3} \mathrm{~N}, \mathrm{CH}_{2} \mathrm{Cl}_{2}$; (d) $\mathrm{O}_{3}, \mathrm{CH}_{3} \mathrm{OH}, \mathrm{CH}_{2} \mathrm{Cl}_{2},-78^{\circ} \mathrm{C}$, (e) $\mathrm{NaBH}_{4}$; (f) $\mathrm{Ph}_{3} \mathrm{P}, \mathrm{I}_{2}$; (g) $t-\mathrm{BuLi}, \mathrm{MgBr}_{2}$. 
Scheme 123. Synthesis of spiroketals 553a-d.
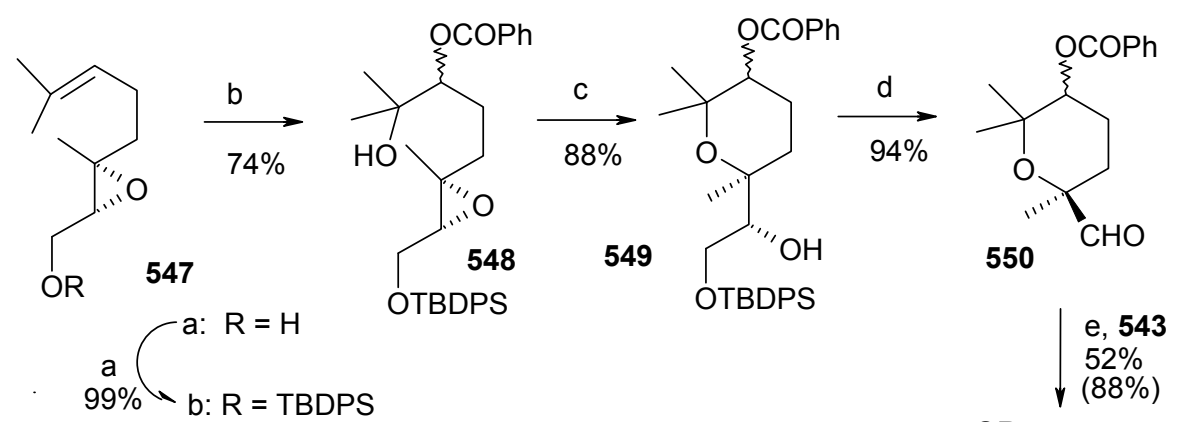

OTBDPS

OTBDPS
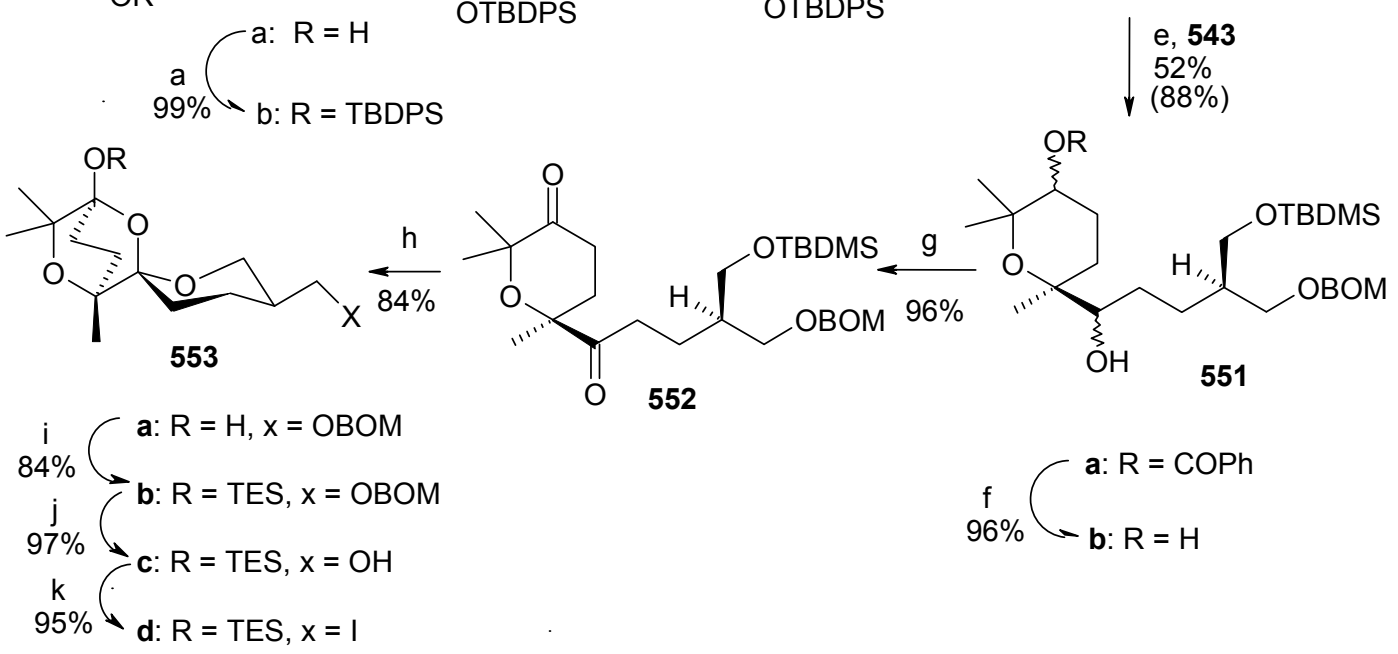

Reagents and conditions: (a) TBDPSCl, $\mathrm{CH}_{2} \mathrm{Cl}_{2}, \mathrm{Et}_{3} \mathrm{~N},-20{ }^{\circ} \mathrm{C}$ to rt; b) $5 \mathrm{ml} \% \mathrm{OsO}_{4}, \mathrm{NMO}, \mathrm{C}_{5} \mathrm{H}_{5} \mathrm{~N}$, tert$\mathrm{C}_{4} \mathrm{H}_{9} \mathrm{OH}$, THF; then $\mathrm{PhCO}_{2} \mathrm{H}$, DCC, DMAP, $\mathrm{CH}_{2} \mathrm{Cl}_{2}$, rt; c) CSA, $\mathrm{CH}_{2} \mathrm{Cl}_{2},-15{ }^{\circ} \mathrm{C}$ to rt; d) TBAF, THF, rt, then $\mathrm{NaIO}_{4}$, THF, $\mathrm{H}_{2} \mathrm{O}, 0{ }^{\circ} \mathrm{C}$; e) $\mathrm{Et}_{2} \mathrm{O},-78{ }^{\circ} \mathrm{C}$; f) $\mathrm{K}_{2} \mathrm{CO}_{3}, \mathrm{CH}_{3} \mathrm{OH}$, rt; g) TPAP, NMO, 4- $\AA \mathrm{MS}, \mathrm{CH}_{2} \mathrm{Cl}_{2}, \mathrm{rt}$; h) $1 \mathrm{~N}$ aq. $\mathrm{HCl}$, THF, rt; I) TESOSO $\mathrm{CF}_{3}$, 2,6-lutidine, $\mathrm{CH}_{2} \mathrm{Cl}_{2}, 0{ }^{\circ} \mathrm{C}$; j) $\left.\mathrm{H}_{2}, 10 \% \mathrm{Pd} / \mathrm{C}, \mathrm{C}_{2} \mathrm{H}_{5} \mathrm{OAc} ; \mathrm{k}\right) \mathrm{Ph}_{3} \mathrm{P}, \mathrm{I}_{2}$, imidazole, $\mathrm{Et}_{2} \mathrm{O}, \mathrm{CH}_{3} \mathrm{CN}, 0{ }^{\circ} \mathrm{C}$.

Oxidative cleavage of 545 with ozone followed by reduction with borohydride gives alcohol 546, which is then converted to the corresponding iodide. The Grignard reagent is prepared by iodidelithium exchange followed by addition of magnesium bromide (Scheme 122).

The aldehyde 550, is synthesized from geraniol epoxide 547 via 548 and 549 as described by Vidari et al., followed by oxidative cleavage (Scheme 123) [215]. The aldehyde 550 is reacted with Grignard reagent 543 to give Grignard product 551a in good yield. Selective hydrolysis of 551a followed by double oxidation with tetrapropylammonium perruthenate (TPAP) produces the diketone 552. Spiroketalysation of $\mathbf{5 5 2}$ with $1 \mathrm{~N} \mathrm{HCl}$ furnishes the desired spiroketal skeleton 553a. The acyclic stereochemistry of diketone $\mathbf{5 5 2}$ directs the folding to place the alkoxymethyl group in an equatorial position. Manipulation of functional groups on 553a provides the iodide 553d for the coupling stage.

The coupling of fragments $\mathbf{5 3 7}$ and $\mathbf{5 3 8}$ is based on alkylation of sulfone-stabilized anion. The sulfone 554b is obtained from the corresponding alcohol 554a by sulfide displacement followed by oxidation [216]. The alkylation is done by treating 554b and 553d with butyl lithium. Treatment of the resulting alkylated product 555 with sodium amalgam gives desulfonylation product 556 along with some elimination product 557. Wittig reaction between 556 and stabilized Wittig reagent 558 gives a mixture of $E: Z$ olefins $\mathbf{5 5 9}$ with a ratio $13: 1$; the major isomer being the $E$ isomer. This is confirmed by proton NMR as the major isomer shows a lower field shift $(\delta=6.70)$, compared to the minor one $(\delta=$ 
6.19). The final compound (+)-Saponaceolide B (560) is obtained by desilylation with tetrabutyl ammonium fluoride (Scheme 124).

Scheme 124. Total synthesis of (+)-saponaceolide B.

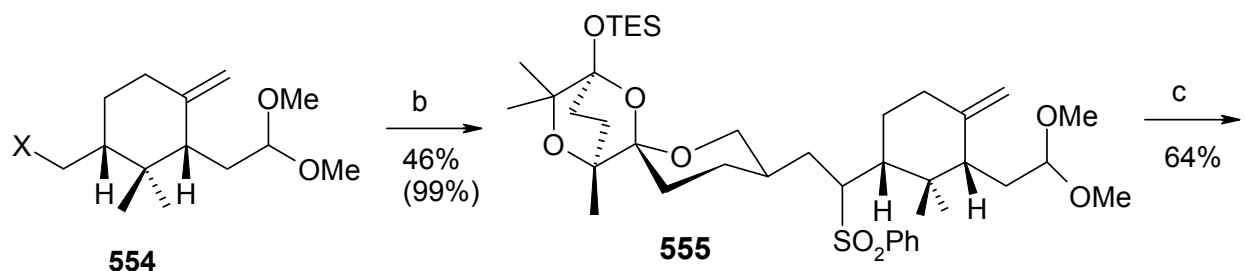

$\underset{86 \%}{\mathrm{a}} C_{b: \mathrm{x}}=\mathrm{SO}_{2} \mathrm{Ph}$

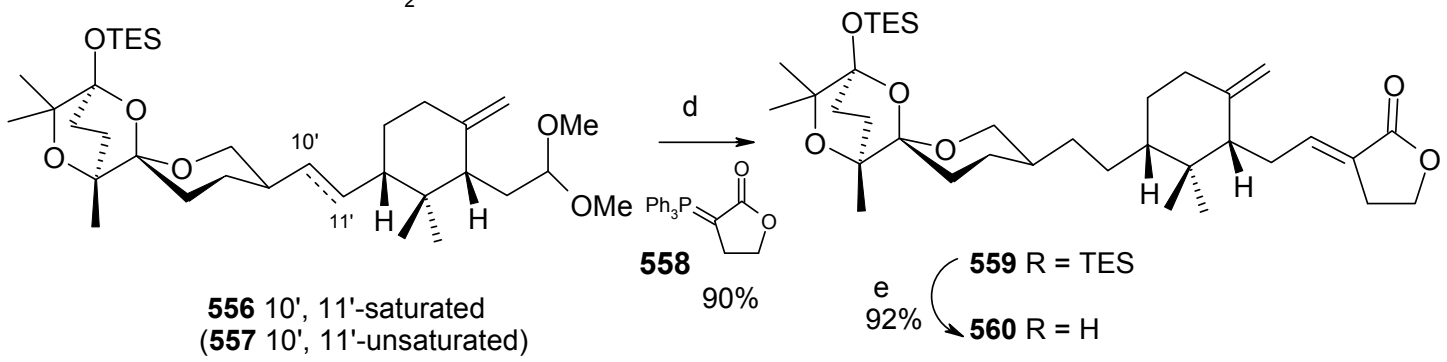

Reagents and conditions: (a) $\left(\mathrm{C}_{4} \mathrm{H}_{9}\right)_{3} \mathrm{P}, \mathrm{PhSSPh}, \mathrm{PhH}$, rt then TPAP, NMO, 4- $\AA$ MS, $\mathrm{CH}_{3} \mathrm{CN}, 0{ }^{\circ} \mathrm{C}$; b) $n$ BuLi, THF, HMPA, 553d, -55 to $-30{ }^{\circ} \mathrm{C}$; c) $5 \% \mathrm{Na}(\mathrm{Hg}), \mathrm{NaH}_{2} \mathrm{PO}_{4}, \mathrm{CH}_{3} \mathrm{OH},-15{ }^{\circ} \mathrm{C}$; d) $\mathrm{CF}_{3} \mathrm{CO}_{2} \mathrm{H}, \mathrm{THF}$, $\mathrm{H}_{2} \mathrm{O}$, rt, then 558, $\mathrm{CH}_{2} \mathrm{Cl}_{2}$, rt; e) TBAF, HOAc, THF, rt.

\subsection{Enantiospecific total synthesis of (-)-Talaromycins $C$ and $E$}

Talaromycins (A-G) are naturally occurring spiroketal mycotoxins produced by the fungus Talaromyces stipitatus. Talaromycin $\mathrm{C}$ and $\mathrm{E}$ were isolated and identified by Lynn et al. [217]. The total asymmetric syntheses of Talaromycins $\mathrm{C}$ and $\mathrm{E}$ were reported by Izquierdo and coworkers [218]. The same group presented enantiospecific synthesis of talaromycins A and B in which D-fructose is used as a chiral starting material [219]. From the retrosynthetic analysis it is evident that talaromycins $\mathrm{A}, \mathrm{B}$, and 9-epi-A-G could be transformed into the corresponding talaromycins C-E and D-F by simply inverting the configuration at $\mathrm{C}-4$. Thus, the four later talaromycins could be prepared from the common 1,2,3,4,5-pentadeoxy-3-C-hydroxymethyldec-6-ulose intermediate 561, depending on the C-3 configuration (Scheme 125).

The synthesis of talaromycins $\mathrm{C}$ and $\mathrm{E}$ is based on the synthesis of first racemic alcohol $3 R S-561$, and then diastereomeric enzymatic resolution to desired $3 S-561$ components. The attempt to make $3 S-$ 561 component by enzymatic desymmetrization of 2-ethyl-1,3-propanediol was unsuccessful, since it gives only 3R-561, although different enzymes are used [220]. Synthesis of 561 is started with 1-Obenzyl-2-ethyl-3-iodopropanol (563), which is converted to its phosphonium salt 564. Treatment of 564 with diacetone D-fructose aldehyde in the presence of tert-butoxide gives both 3- $C$ (benzyloxymethyl)-1,2,3,4,5-pentadeoxy-6,7:8,9-di- $O$-isopropylidene- $\beta$-D-gluco- and-D-manno-dec4-ene-6-ulo-6,10-pyranose $\mathbf{5 6 6}$ as a mixture of $E$ and $Z$ isomers, which is subsequently hydrogenated to give $3 R S-561$ ( $89 \%$ yield) (Scheme 126). The compound $3 R S-561$ is then treated with vinyl acetate 
in the presence of Chirazyme ${ }^{(\mathbb{R})} \mathrm{L}-2$, c.-f., $\mathrm{C} 2$ to afford the corresponding acetate $3 S-\mathbf{5 6 7}$, along with unreacted 3R-561 (Scheme 127).

Scheme 125. Retrosynthetic analysis of (-)-talaromycins C and E.

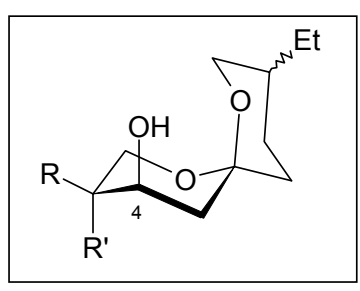

Talaromycins C,E, D, F

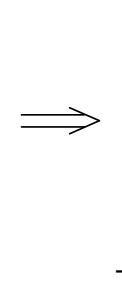

$$
\mathrm{R}=\mathrm{R}^{\prime}=\mathrm{H} \text { or } \mathrm{CH}_{2} \mathrm{OH}
$$$$
\text { Talaromycins A, B, 9-epi-A, G }
$$

D-Fructose
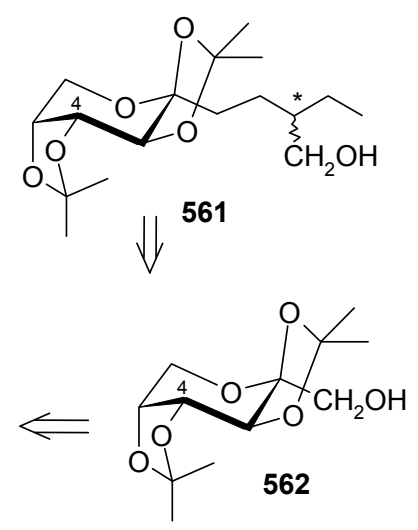

The determination of the diastereomeric excess of either compound by GLC was unsuccessful, even on a capillary $\beta$-DEX ${ }^{(\mathrm{R})} 325$ column and therefore they were subjected to spiroketalysation by treating with acetone/sulfuric acid to give spiroketals $(3 R, 4 S, 5 S, 6 R, 9 R)$ - and $(3 R, 4 S, 5 S, 6 R, 9 S)$-9-ethyl-3,4isopropylidenedioxy-1,7-dioxaspiro[5.5] undecane (568 and 569). The result was not sattisfactory since the diastereomeric excess is small. Therefore, the partial enzymatic hydrolysis of $3 R S-561$ is also performed which gives a better diastereomeric excess [218]. This may be due to the larger size or the hydrophobicity of the substituent at the stereocenter.

Scheme 126. Synthesis of intermediate 561.

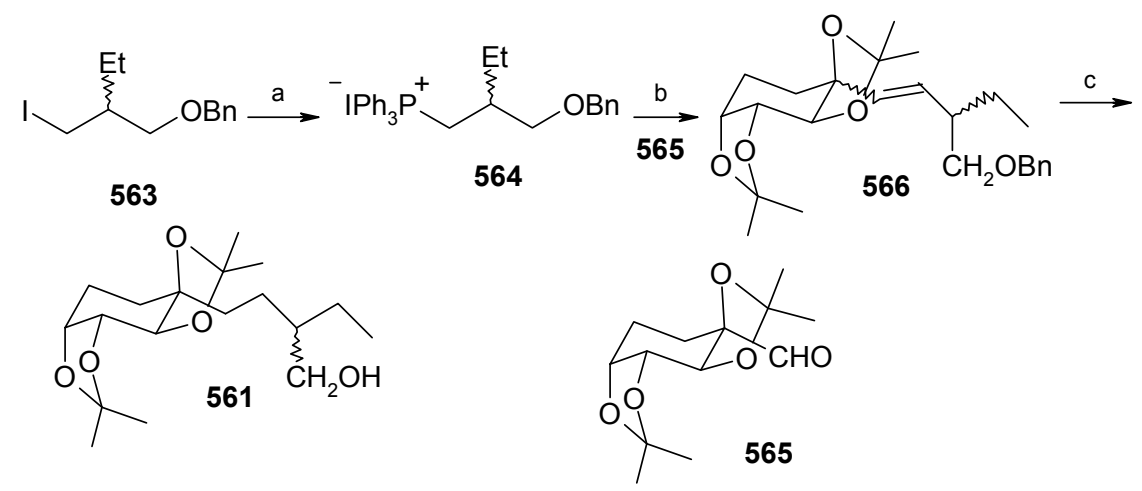

Reagents and conditions: (a) $\mathrm{Ph}_{3} \mathrm{P}$, toluene, heat; (b) 565, $\mathrm{K}^{t} \mathrm{OBu}, \mathrm{THF}$; (c) $\mathrm{Pd} / \mathrm{C}, \mathrm{H}_{2}, \mathrm{MeOH}$.

Compound 568 is deoxygenated through its 5-O-xanthate with a modified Barton procedure [221] $\mathbf{5 7 0}$, to afford 571, which is subjected to hydrolysis by a reported procedure [219] to give diol $\mathbf{5 7 2}$ (Scheme 128). Compound $\mathbf{5 7 2}$ is converted to its $n$-dibutylstannylene derivative $\mathbf{5 7 3}$, which is then regioselectively silylated at C-4 to give 574. Oxidation of 574 with PCC affords the corresponding ketone 575, which is coupled with methylenetriphenylphosphorane to afford 576. Hydroboration 
followed by oxidation of $\mathbf{5 7 6}$ gives an unresolved mixture (3:7 ratio) of 4- $O$-silylated talaromycins B, $\mathbf{5 7 7}$ and A, 578, which are separated as their benzoyl derivatives $\mathbf{5 7 9}$ and $\mathbf{5 8 0}$ respectively.

Scheme 127. Diastereomeric resolution of 561.

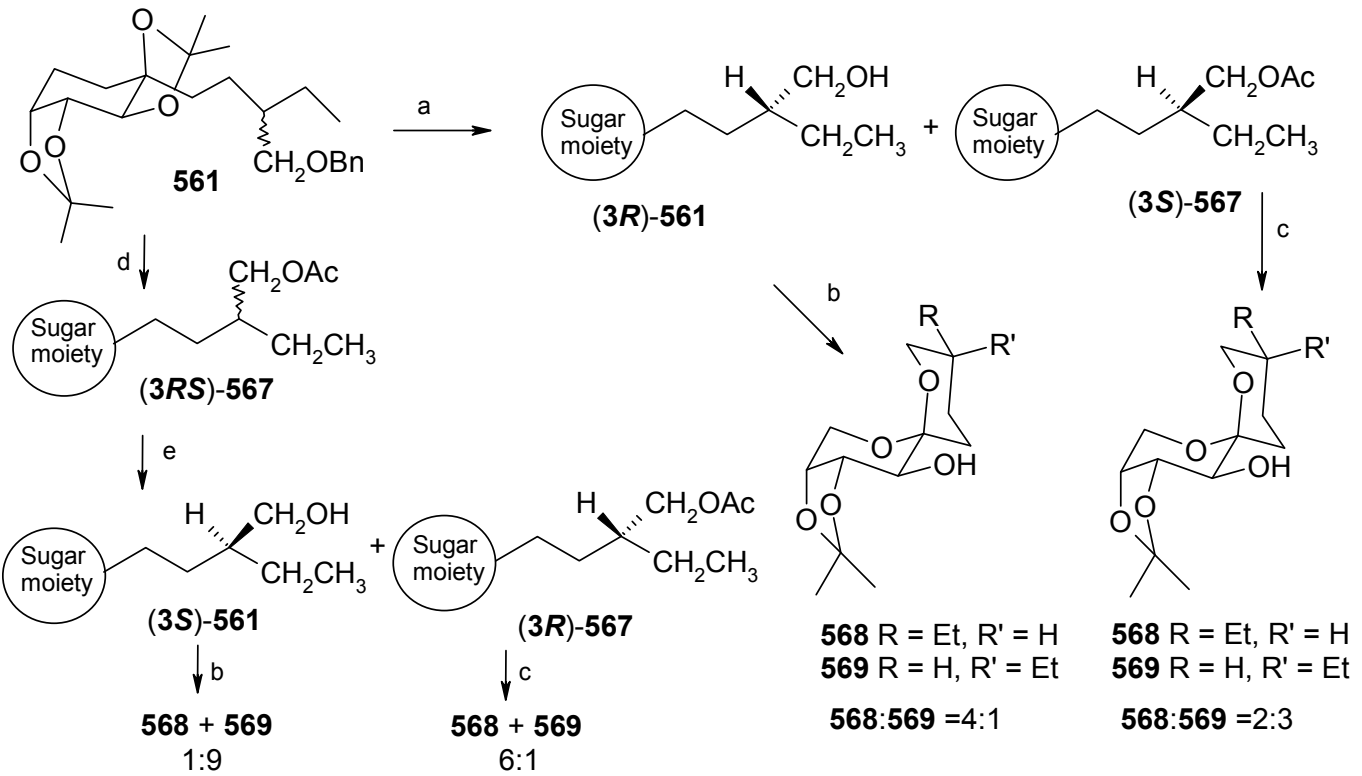

Reagents and conditions: (a) Chirazyme ${ }^{\circledR} \mathrm{L}-2$, c-f., $\mathrm{C} 2$ /vinyl acetate; (b) $\mathrm{Me}_{2} \mathrm{CO} / \mathrm{H}^{+}$; (c) (i) $\mathrm{NaOMe}, \mathrm{MeOH}$, (ii) $\mathrm{Me}_{2} \mathrm{CO} / \mathrm{H}+$; (d) $\mathrm{Ac}_{2} \mathrm{O}, \mathrm{CH}_{2} \mathrm{Cl}_{2}, \mathrm{Et}_{3} \mathrm{~N}$, DMAP; (e) Chirazyme®L-2, c-f., $\mathrm{C} 2 /$ buffer (pH = 7) rt.

Scheme 128. Synthesis of protected (-)-talaromycins B (579) and A (580).

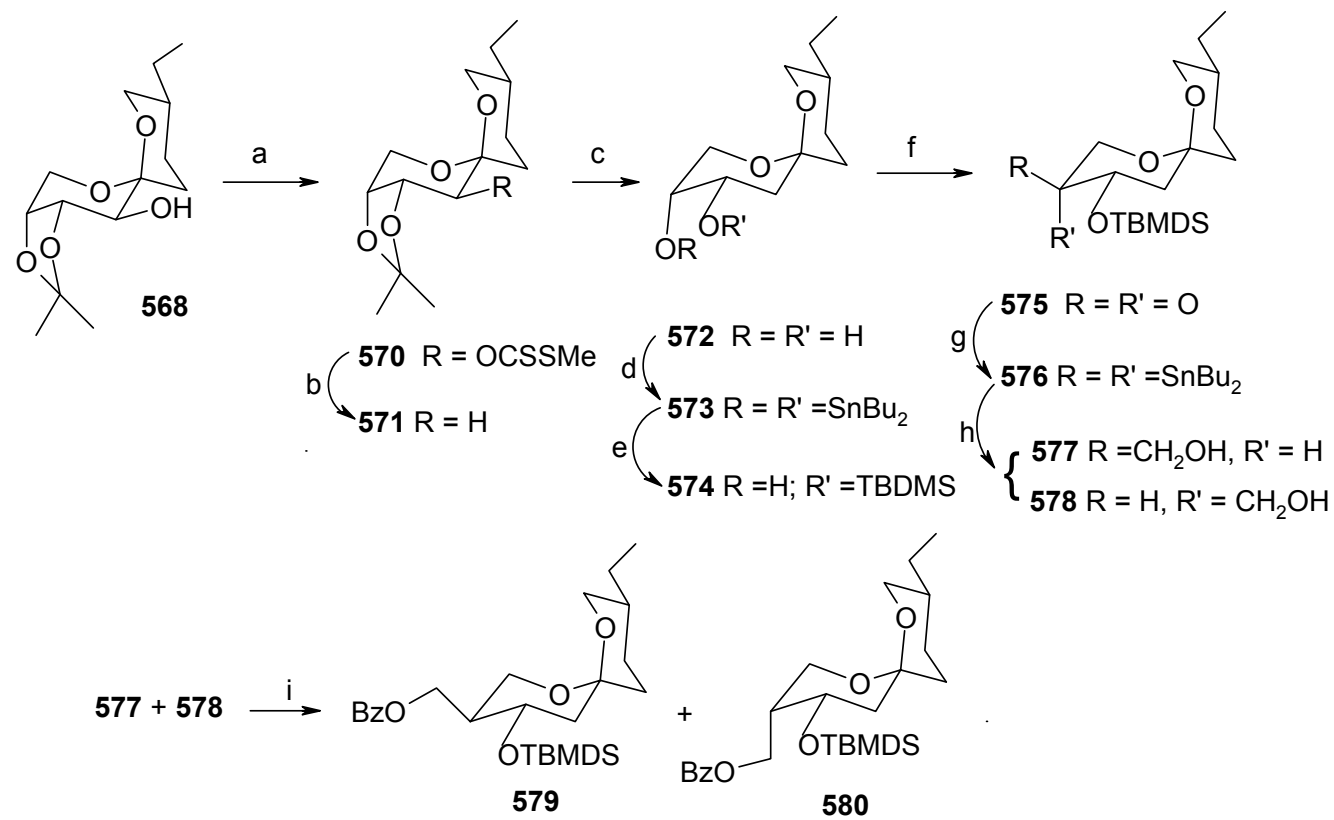

Reagents and conditions: (a) NaH/THF/imidazole/ $/ \mathrm{CS}_{2} / \mathrm{MeI} ;$ b) $\mathrm{H}_{3} \mathrm{PO}_{4} /$ dioxane $/ \mathrm{H}_{2} \mathrm{O} / \mathrm{Et}_{3} \mathrm{~N} / \mathrm{AIBN}$; c) $\mathrm{AcOH} / \mathrm{H}_{2} \mathrm{O} / 50{ }^{\circ} \mathrm{C} / 1 \mathrm{~h}$; d) $n \mathrm{Bu} \mathrm{Lu}_{2} \mathrm{SnO} / \mathrm{MeOH}$; e) TBDMSCl$/$ dioxane; f) $\mathrm{PCC} / \mathrm{CH}_{2} \mathrm{Cl}_{2} / \mathrm{NaOAc} / \mathrm{MS} 4 \AA$; g) $\mathrm{NaCH}_{2} \mathrm{SOCH}_{3} / \mathrm{Ph}_{3} \mathrm{PCH}_{3} \mathrm{Br} / \mathrm{DMSO}$; h) $\mathrm{BH}_{3}-\mathrm{SMe}_{2} / \mathrm{THF}$, then $\mathrm{NaOH} / \mathrm{H}_{2} \mathrm{O}_{2}$; I) $\mathrm{BzCl} / \mathrm{Et}_{3} \mathrm{~N} / \mathrm{CH}_{2} \mathrm{Cl}_{2}$. 
Scheme 129. Total synthesis of (-)-Talaromycins C and E.

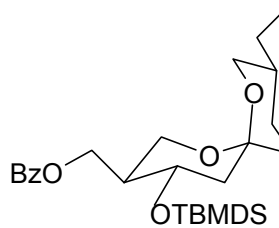

579

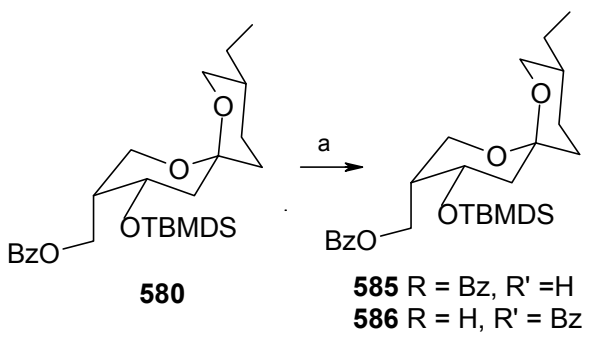

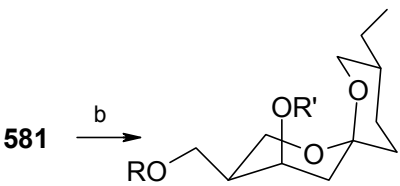

c $\left\{\begin{array}{c}583 \mathrm{R}=\mathrm{Bz}, \mathrm{R}^{\prime}=3,5-\mathrm{DNBz} \\ 584 \text { Talaromycin E R =R = H }\end{array}\right.$

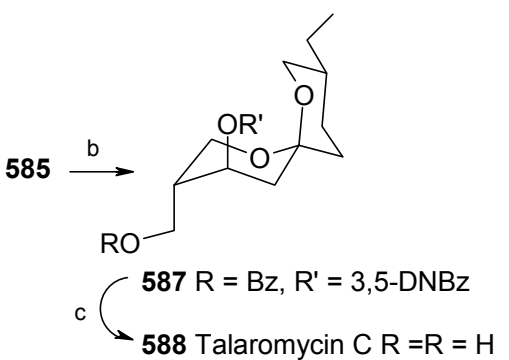

Reagents and conditions: (a) $n$ - $\mathrm{Bu}_{4} \mathrm{NF} .3 \mathrm{H}_{2} \mathrm{O}$, THF; (b) $\mathrm{Ph}_{3} \mathrm{P}, 3$,5-dinitrobenzoic acid, DEAD, $\mathrm{rt}$; (c) $\mathrm{NaOMe}, \mathrm{MeOH}$.

Desilylation of $\mathbf{5 7 9}$ and $\mathbf{5 8 0}$ with tetrabutyl ammonium fluoride affords compounds $\mathbf{5 8 1}$ and $\mathbf{5 8 5}$ along with minute amount of their corresponding 12- $O$ to 4-O benzoyl migrated compounds 582 and $\mathbf{5 8 6}$ respectively. Inversion of configuration at C-4 of both the compounds $\mathbf{5 8 1}$ and $\mathbf{5 8 5}$ by Mitsunobu reaction affords 583 and 587. Finally, Zemplen deacetylation of 583 and $\mathbf{5 8 7}$ gives the expected molecules (-)-talaromycin E, 584 (72\%) and C, 588 (86\%), respectively (Scheme 129).

\subsection{Total synthesis of Siphonarin B and Dihydrosiphonarin B}

Siphonarin B is an unusual $\gamma$-pyrone polypropionate, containing a characteristic spiroacetal ring, which was first isolated by Faulkner and Ireland and their co-workers from the marine molluscus, Siphonaria zelandica and S. atra, collectected on the coast of New South Wales, Australia [222]. Dihydrosiphonarin B was obtained from a siphonariid collection made in Hawaii [223]. Paterson et al. have reported the total synthesis of siphonarin B and dihydrosiphonarin B (Figure 3) [223].

Figure 3. Structures of Siphonarin B and Dihydrosiphonarin B.<smiles>[R]c1oc([C@H]2O[C@]3(O[C@H](C(C)C([Y])([X])CC)[C@@H](C)C(=O)[C@H]3C)[C@@H](C)[C@H](O)[C@@H]2C)c(C)c(=O)c1C</smiles>

Siphonarin $\mathrm{B}: \mathrm{X}-\mathrm{Y}=\mathrm{O}, \mathrm{R}=\mathrm{Et}$

Dihydrosiphonarin $\mathrm{B}$ : $\mathrm{X}=\mathrm{OH}, \mathrm{Y}=\mathrm{H}, \mathrm{R}=\mathrm{Et}$ 
The retrosynthetic pathway of siphonarin B reveals that the triketones $\mathbf{5 8 9}$ (C1-C21) and 592 (C3C21) are protected acyclic precursors. There are two approaches starting from precursors $\mathbf{5 8 9}$ and $\mathbf{5 9 2}$. The first approach is based on the assumption that C8-C9 aldol coupling between ketone $\mathbf{5 9 0}$ and aldehyde 591 followed by oxidation of the $9-\mathrm{OH}$ and $13-\mathrm{OH}$ and the release of the 5-OH to initiate a cascade to deliver the spiro-bis-acetal ring system (Scheme 130).

Scheme 130. Retrosynthetic analysis of siphonarin B.

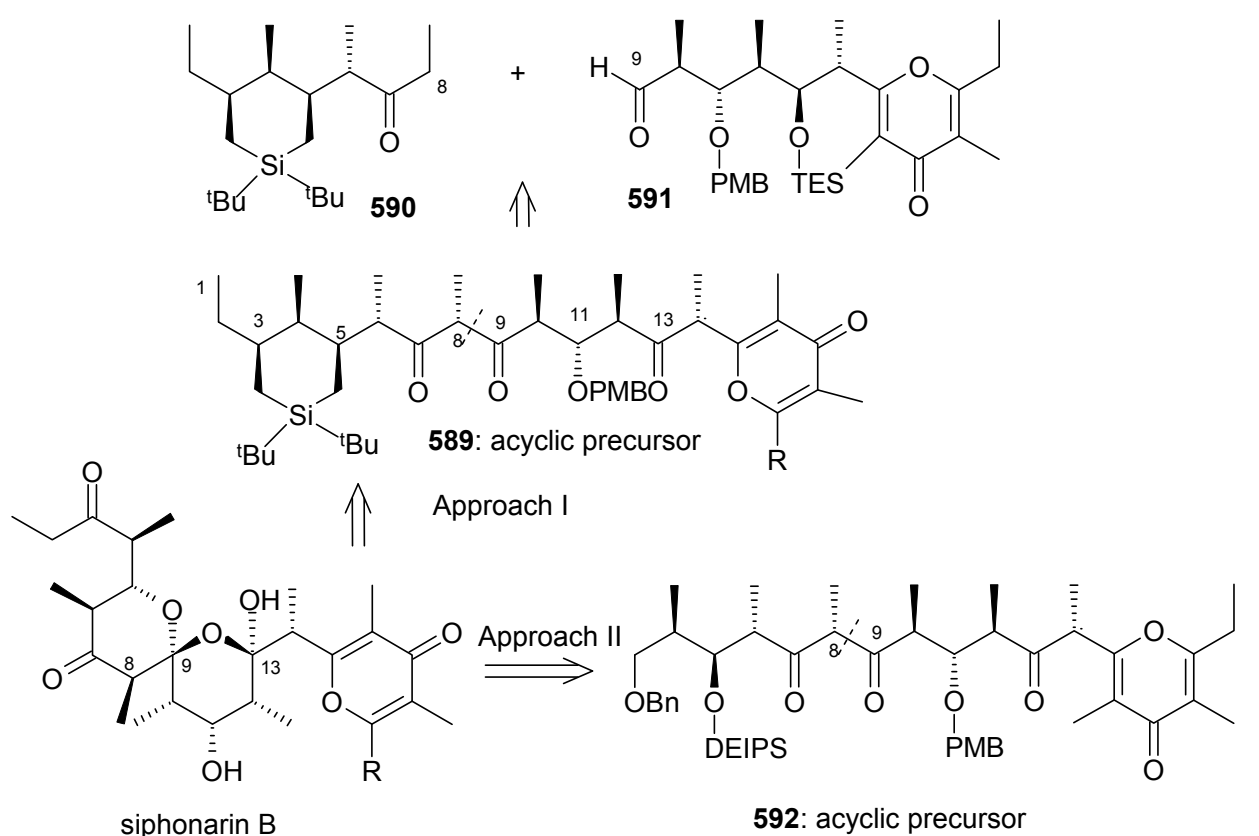

The preparation of ketone $\mathbf{5 9 0}$ starts with an asymmetric aldol condensation between 3-pentanone 593 and (E)-2-methyl-2-pentenal using (-)-Ipc ${ }_{2}$ BOTf [224]. The resulting product 594 is reduced to 1,3-syn diol 595 using the Narasaka protocol, followed by silyl protection; hydroboration and DessMartin oxidation gives compound 590 [225] (Scheme 131). The aldehyde component 591 is obtained from the diol 596 by a sequence of bis-TES protection, selective cleavage, and Dess-Martin oxidation (Scheme 131).

The aldol condensation between $\mathbf{5 9 0}$ and $\mathbf{5 9 1}$ is carried out using $\mathrm{Sn}(\mathrm{OTf})_{2} / \mathrm{Et}_{3} \mathrm{~N}$ leading to a mixture of adducts $\mathbf{5 9 7}$ (ca. 60:40 ds in favor of the 6,8-syn-8,9-syn isomer). The syn product is subjected to selective deprotection of TES and the Dess-Martin oxidation to give triketone 589 . Deprotection of cyclic silyl ether using HF-pyridine gives hemiacetal $\mathbf{5 9 8}$ instead of spirocyclisation. After oxidative removal of PMB ether lead to the spiroacetal 599 accompanied by epimerisation at $\mathrm{C}-8$. This acetal ring is stabilized by a double anomeric effect, and alkyl substituent at equatorial position.

Attempt to isomerise the compound 599 using several acidic conditions to generate 3-epidihydrosiphonarin $\mathbf{6 0 0}$ is failed (Scheme 131). Since the first approach is failed a modified precursor 592 is used for the synthesis of siphonarin B and dihydrosiphonarin B. In this approach the preparation of 592 is started with aldol condensation between ketone $\mathbf{6 0 1}$ and propionaldehyde followed by reduction by $\mathrm{LiBH}_{4}$ to give 1,3 diol $\mathbf{6 0 2}(95: 5 \mathrm{ds})$. 
Scheme 131. Synthesis of ketone 590, aldehyde 591 and spiroacetal 599.

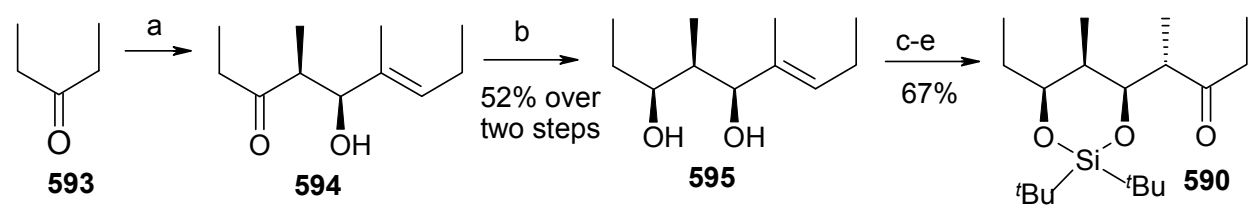

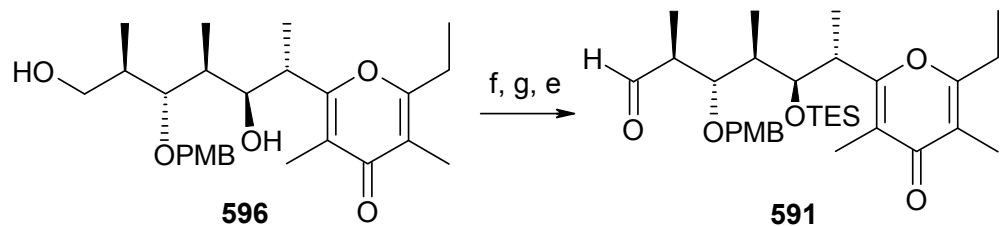

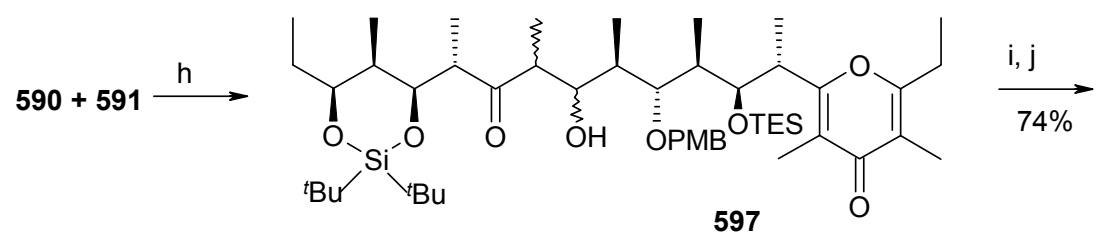

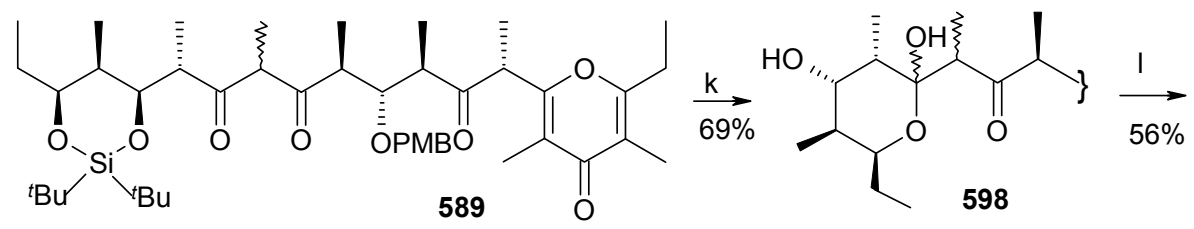

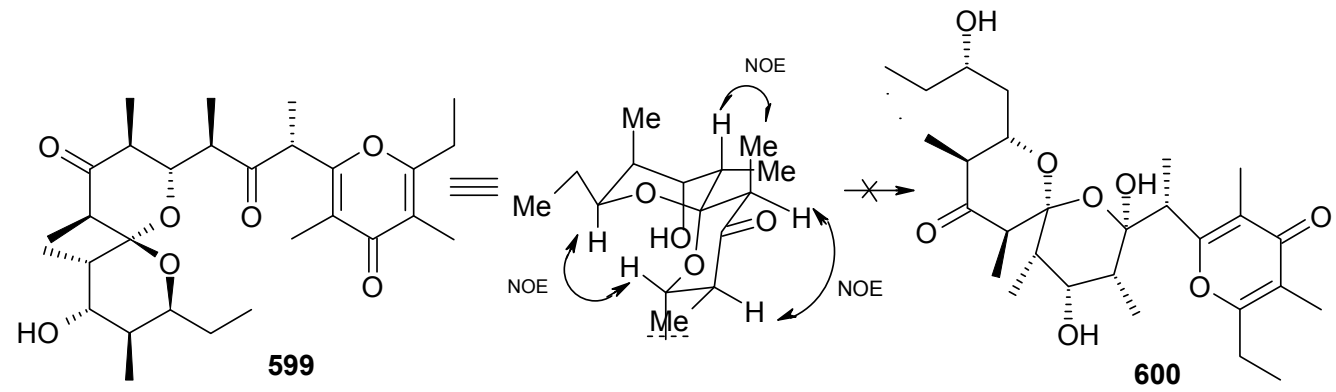

Reagents and conditions: a) (E)-2-methyl-2-pentenal, (-)-Ipc ${ }_{2} \mathrm{BOTf}, i \mathrm{Pr}_{2} \mathrm{NEt}, \mathrm{CH}_{2} \mathrm{Cl}_{2} ;$ b) $n$ - $\mathrm{Bu}_{2} \mathrm{BOMe}$, THF/MeOH, $\mathrm{LiBH}_{4}$; c) $t$ - $\mathrm{Bu}_{2} \mathrm{Si}(\mathrm{OTf})_{2}$, 2,6-lutidine, $\mathrm{CH}_{2} \mathrm{Cl}_{2}$; d) Thexylborane, THF, $\mathrm{H}_{2} \mathrm{O}_{2}, \mathrm{NaOH}$; e) DessMartin periodinane, $\mathrm{CH}_{2} \mathrm{Cl}_{2}$; f) TESOTf, 2,6-lutidine, $\mathrm{CH}_{2} \mathrm{Cl}_{2}$, g) AcOH/THF/H $\mathrm{H}_{2} \mathrm{O}$; h) $\mathrm{Sn}(\mathrm{OTf})_{2}, \mathrm{Et}_{3} \mathrm{~N}$, $\mathrm{CH}_{2} \mathrm{Cl}_{2}$; I) PPTS, $\mathrm{MeOH} / \mathrm{CH}_{2} \mathrm{Cl}_{2}$; j) $(\mathrm{COCl})_{2}$, DMSO, $\mathrm{CH}_{2} \mathrm{Cl}_{2}$; Et 3 N; k) HF.Py/Py, THF; l) DDQ, $\mathrm{CH}_{2} \mathrm{Cl}_{2} / \mathrm{pH}$ 7 buffer.

Protection of diol 602 with DEIPSCl followed by selective deprotection of less hindered silyl ether to alocohol and then oxidation of free alcohol to ketone gives compound 603. Similarly bis-TMS protection of diol 596 followed by selective cleavage of the primary silyl ether and the Dess- Martin oxidation affords the $\gamma$-pyrone aldehyde $\mathbf{6 0 4}$, which is subjected to react with the $\mathrm{Sn}(\mathrm{II})$ enolate of ketone $\mathbf{6 0 3}$ to give a mixture of aldol adduct $\mathbf{6 0 5}$ (ca. 73:27 ds in favor of the 6,8-syn-8,9-syn isomer). 
Scheme 132. Total synthesis of siphonarin B and dihydrosiphonarin B.

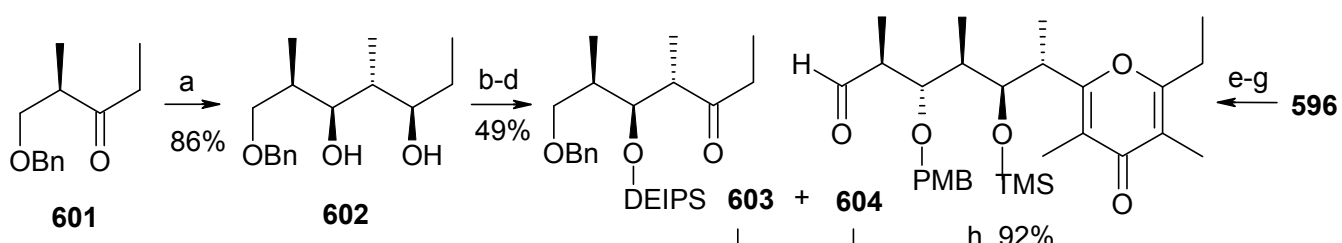

601 h, $92 \%$

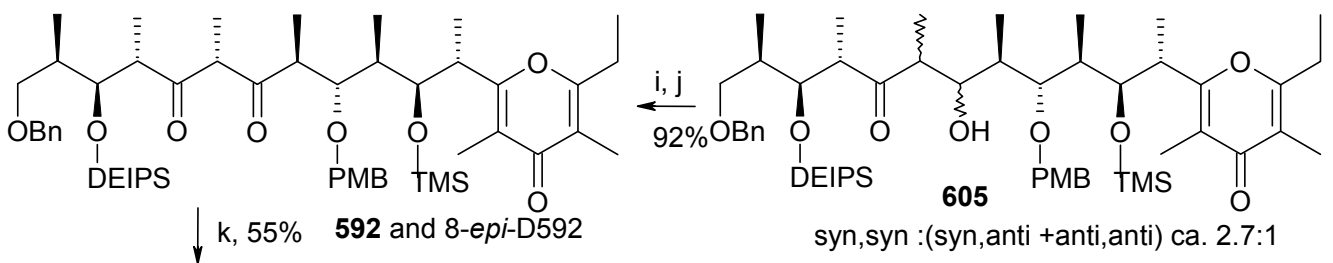

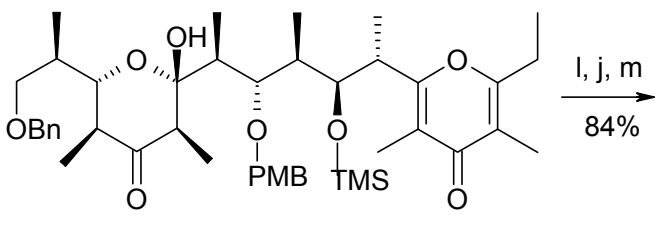

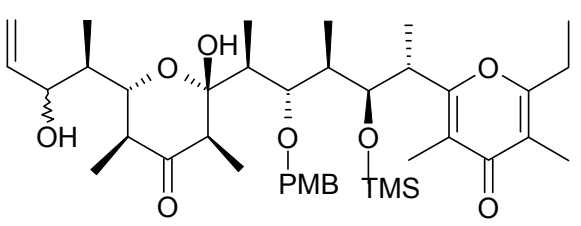

606

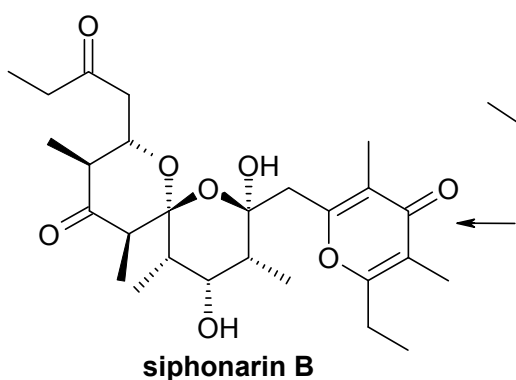

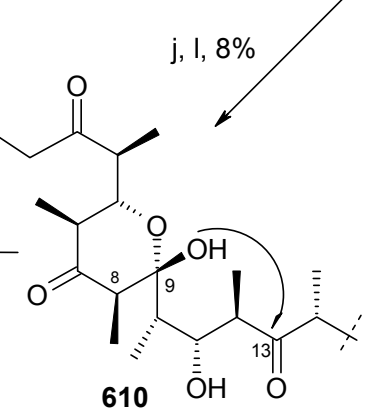

609<smiles>CCc1oc(C[C@]2(O)O[C@@]3(O[C@H](C[C@H](O)CC)[C@@H](C)C(=O)[C@H]3C)[C@H](C)[C@H](O)[C@@H]2C)c(C)c(=O)c1C</smiles>

Reagents and conditions: a) $\left.(c-\mathrm{Hex})_{2} \mathrm{BCl}, \mathrm{Et}_{3} \mathrm{~N}, \mathrm{Et}_{2} \mathrm{O}, \mathrm{EtCHO} ; \mathrm{LiBH}_{4} ; \mathrm{b}\right) \mathrm{DEIPSCl}$, imidazole, DMF; c) PPTS, $\mathrm{MeOH} / \mathrm{CH}_{2} \mathrm{Cl}_{2}$; d) Dess-Martin periodinane, $\mathrm{CH}_{2} \mathrm{Cl}_{2}$; e) TMSOTf, 2,6-lutidine, $\left.\mathrm{CH}_{2} \mathrm{Cl}_{2}, \mathrm{f}\right) \mathrm{K}_{2} \mathrm{CO}_{3}$, $\mathrm{MeOH} ; \mathrm{g})$ Dess-Martin periodinane, $\mathrm{Py}, \mathrm{CH}_{2} \mathrm{Cl}_{2}$; h) $\mathrm{Sn}(\mathrm{OTf})_{2}, \mathrm{Et}_{3} \mathrm{~N}, \mathrm{CH}_{2} \mathrm{Cl}_{2} ;$ i) PPTS, $\mathrm{MeOH} / \mathrm{CH}_{2} \mathrm{Cl}_{2} ; \mathrm{j}$ ) $(\mathrm{COCl})_{2}, \mathrm{DMSO}, \mathrm{CH}_{2} \mathrm{Cl}_{2}, \mathrm{Et}_{3} \mathrm{~N}$; k) HF.Py/Py, THF; l) $\left.\mathrm{Pd} / \mathrm{C}, \mathrm{H}_{2}, \mathrm{EtOH} ; \mathrm{m}\right) \mathrm{NiCl}_{2} / \mathrm{CrCl}_{2}\left(5 \% \mathrm{NiCl}_{2}\right)$, $\mathrm{H}_{2} \mathrm{C}=\mathrm{CHI}, \mathrm{DMF}$.

Selective deprotection of the TES ether, followed by double Swern oxidation gives the desired triketone 592 (and its C-8 epimer, ca. 2.7:1; 92\%). Desilylation of cyclic silyl ether lead to the formation of six membered hemiacetal 606, in which all the alkyl substituents in the equatorial position. This hemiacetal $\mathbf{6 0 6}$ is very sensitive to mild acid or bases and exposure to these resulted in a retro-Claisen reaction, producing the baconipyrone ester 607 (Scheme 133). On the other hand hydrogenolysis of the benzyl and PMB ethers lead to the desired thermodynamically favorable spirobis-acetal core $\mathbf{6 0 8}$ where all the alkyl substituents are equatorially oriented with anomeric stabilysation at the $\mathrm{C}-9$ and $\mathrm{C}-13$ acetal centers. This indicates that mild reaction conditions and work up procedures are crucial for the remaining synthesis of siphonarin $\mathrm{B}$. Therefore, the benzyl group is removed under controlled conditions $\left(\mathrm{H}_{2}, \mathrm{Pd} / \mathrm{C}, \mathrm{EtOH}\right)$ with retension of the PMB ether, followed by Swern oxidation of the resulting primary alcohol to give the labile aldehyde which is immediately subjected to Kishi-Nozaki coupling to give a mixture (ca. 2.5:1) of allylic alcohol 609 in $84 \%$ yield [226,227]. The compound $\mathbf{6 0 9}$ is subjected to Swern oxidation to give enone, which is then selectively 
reduced to saturated ketone with concomitant removal of the PBM ether. Interestingly this step also furnished the desired spirocyclisation through hemiacetalization between the 9-OH and the C-13 ketone in 610, leading to isolation of $(+)$-siphonarin B. Similarly dihydrosiphonarin B is obtained by catalytic hydrogenation of the major epimer at C-3 in 609 (Scheme 132).

Scheme 133. Generation of spirocyclic core of the siphonarins.
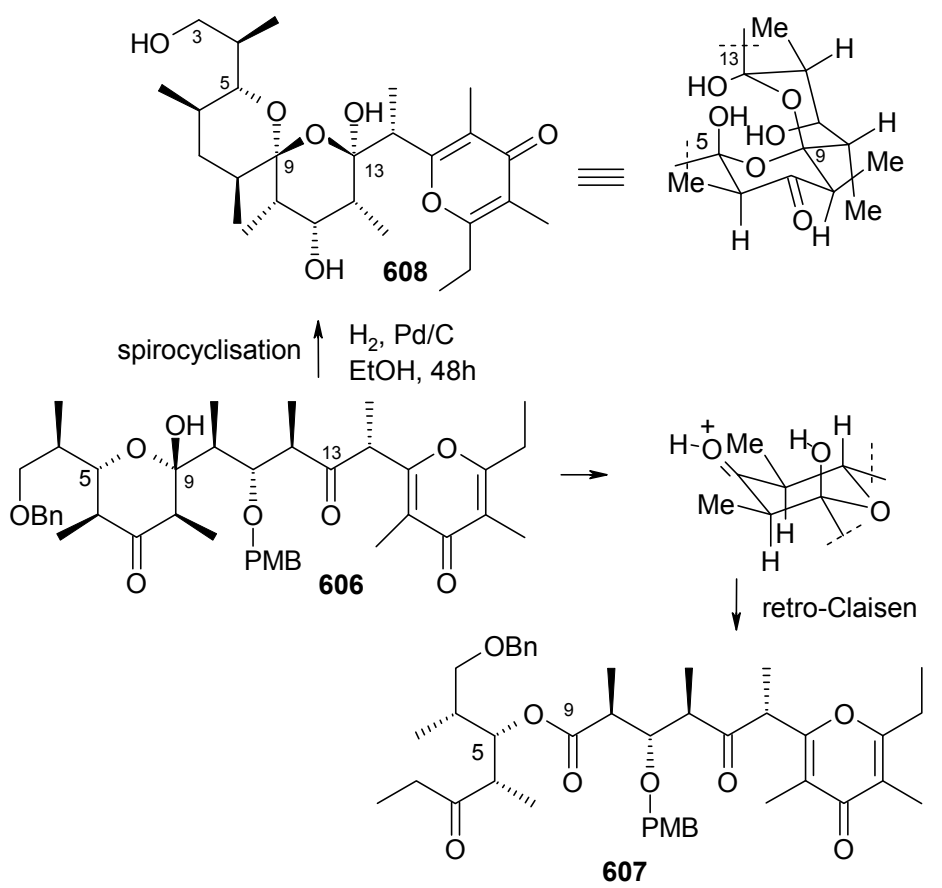

\section{Conclusions}

One of the purposes of this review is to attract the attention of the synthetic chemists to the total asymmetric synthesis of naturally occurring spiroketals. Asymmetric synthesis of twenty-seven natural products having spiroketal unit have been presented.

\section{References and Notes}

1. Perron, F.; Albizati, K. F. Chemistry of spiroketals. Chem. Rev. 1989, 89, 1617-1661.

2. Mead, K. T.; Brewer, B. N. Strategies in spiroketal synthesis revisited: Recent applications and advances. Curr. Org. Chem. 2003, 7, 227-256.

3. Brimble, M. A.; Furkert, D. P. Chemistry of bis-spiroacetal systems: Natural products, synthesis and stereochemistry. Curr. Org. Chem. 2003, 7, 1461-1484.

4. Koshino, H.; Takahashi, H.; Osada, H.; Isono, K. Reveromycins, new inhibitors of eukaryotic cell growth. J. Antibiot. 1992, 45, 1420-1427.

5. Shimizu, T.; Machida, K.; Furuya, K.; Osada, H.; Nakata, T. Chemical modification of reveromycin A and its biological activities. Bioorg. Med. Chem. Lett. 2002, 12, 3363-3366. 
6. Pettit, G. R.; Inoue, M.; Kamano, Y.; Herald, D. L.; Arm, C.; Dufresne, C.;Christie, N. D.; Schmidt, J. M.; Doubek, D. L.; Krupa, T. S. Antineoplastic agents. 147. Isolation and structure of the powerful cell growth inhibitor cephalostatin1. J. Am. Chem. Soc. 1998, 120, 2006-2007.

7. Muller, I. M.; Dirsch, V. M.; Rudy, A.; Lopez-Anton, N.; Pettit, G. R.; Vollmar, A. M. Cephalostatin 1 inactivates Bcl-2 by hyperphosphorylation independent of M-phase arrest and DNA damage. Mol. Pharmacol. 2005, 67, 1684-1689.

8. Ueno, T.; Takahashi, H.; Oda, M.; Mizunuma, M.; Yokoyama, A.; Goto, Y.; Mizushina, Y.; Sakaguchi, K.; Hayashi, H. Inhibition of human telomerase by rubromycins: Implication of spiroketal system of the compounds as an active moiety. Biochemistry 2000, 39, 5995-6002.

9. Li, A.; Piel, J. Gene cluster from a marine streptomyces encoding the biosynthesis of the aromatic spiroketal polyketide griseorhodin A. Chem. Biol. 2002, 9, 1017-1026.

10. Francke, W.; Kitching, W. Spiroacetals in insects. Curr. Org. Chem. 2001, 5, 233-251.

11. Exceptions were reported, e.g.: Stok, J. E.; Lang, C.-S.; Schwartz, B. D.; Fletcher, M. T.; Kitching, W.; de Voss, J. J. Carbon hydroxylation of alkyltetrahydropyranols: A paradigm for spiroacetal biosynthesis in Bactrocera sp. Org. Lett. 2001, 3, 397-400, references [1] and [10]

12. Bender, T.; Schuhmann, T.; Magull, J.; Grond, S.; Zezschwitz, P. Comprehensive study of okaspirodiol: characterization, total synthesis, and biosynthesis of a new metabolite from streptomyces. J. Org. Chem 2006, 71, 7125 - 7132.

13. Philips, C.; Jacobson, R.; Abrahams, B.; Williams, H. J.; Smith, L. R. Useful route to 1,6dioxaspiro[4.4]nonane and 1,6-dioxaspiro[4.5]decane derivatives. J. Org. Chem. 1980, 45, 19201924.

14. Hayes, P.; Fletcher, M. T.; Moore, C. J.; Kitching, W. Synthesis and absolute stereochemistry of a constitutionally new spiroacetal from an insect. J. Org. Chem. 2001, 66, 2530-2533.

15. Hungerbuhler, E.; Naef, R.; Wasmuth, D.; Seebach, D.; Loosli, H. R.; Wehrli, A. Synthesis of optically active 2-methyl- and 2-methyl-1,6-dioxaspiro[4.4] nonane and -[4.5] decane pheromones from common chiral precursor. Helv. Chim. Acta. 1980, 63, 1960-1970.

16. Ueki, T.; Kinoshita, T. Stereoselective synthesis and structure of butalactin and lactone II isolated from Streptomyces species. Org. Biomol. Chem. 2004, 2, 2777-2785.

17. White, J. D.; Somers, T. C.; Reddy, G. N. Degradation and absolute configurational assignment to C34-botryococcene. J. Org. Chem. 1992, 57, 4991-4998.

18. Phillips, C.; Jacobsen, R.; Abrahams, B.; Williams, H. J.; Smith, L. R. Useful route to 1,6dioxaspiro[4.4]nonane and 1,6-dioxaspiro[4.5]decane derivatives. J. Org. Chem. 1980, 45, 19201924.

19. Shiozawa, H.; Takahashi, M.; Takatsu, T.; Kinishita, T.; Tanazawa, K.; Hosoya, T.; Furuya, K.; Takahashi, S.; Furihata, K.; Seta, H. Trachyspic acid, a new metabolite produced by talaromyces trachyspermus, that inhibits tumor cell heparanase: Taxonomy of the producing strain, fermentation, isolation, structural elucidation, and biological activity. J. Antibiot. 1995, 48, 357362.

20. For a recent review see: Neta, I.; Micheal, E.; Israel, V. Regulation, function and clinical significance of heparanase in cancer metastasis and angiogenesis. Int. J. Biochem. Cell Biol. 2006, 38, 2018-2039. 
21. Zammit, S.C., Ferro,V.; Hammond, E.; Rizzacasa, M. A. Enantiospecific synthesis of the heparanase inhibitor (+)-trachyspic acid and stereoisomers from a common precursor. Org. Biomol. Chem. 2007, 5, 2826-2834.

22. Zammit, S.C.; White, J. M.; Rizzacasa, Enantiospecific synthesis of (-)-trachyspic acid. Org. Biomol. Chem. 2005, 3, 2073.

23. Di Florio, R.; Rizzacasa, M. A. Synthesis of 2,2-disubstituted furanoid natural products: Total synthesis of sphydrofuran. J. Org. Chem. 1998, 63, 8595-8598.

24. Giuliano, R. M.; Villani, F. J. Jr., Stereoselectivity of addition of organometallic reagents to pentodialdo-1,4-furanoses: Synthesis of L-axenose and D-evermicose from a common intermediate. J. Org. Chem. 1995, 60, 202-211.

25. Kingsbury, C. L.; Sharp, K. S.; Smith, R. A. J. Effects of dimethyl sulfide on the reaction of dibutylcopper reagents with $\alpha, \beta$-unsaturated ketones. Tetrahedron 1999, 55, 14693-14700.

26. Laschober, R. Stadlbauer, W. Synthesis of 3-heptyl- and 3-nonyl-2,4(1H,3H)-quinolinediones. Liebigs Ann. Chem. 1990, 11, 1083-1086.

27. McDougal, P. G.; Rico, J. G.; Oh, Y.; Condon, B. D. A convenient procedure for the monosilylation of symmetric 1,n-diols. J. Org. Chem. 1986, 51, 3388-3390.

28. Corey, E. J.; Fuchs, P. L. A synthetic method for formyl $\rightarrow$ ethynyl conversion. Tetrahedron Lett. 1972, 13, 3769-3772.

29. Hirai, K.; Ooi, H.; Esumi, T.; Iwabuchi, Y.; Hatakeyama, S. Total synthesis of ( \pm )-trachyspic acid and determination of the relative configuration. Org. Lett. 2003, 5, 857-859.

30. Martin, S. F.; Dodge, J. A. Efficacious modification of the mitsunobu reaction for inversions of sterically hindered secondary alcohols. Tetrahedron Lett. 1991, 32, 3017-3020.

31. Deffieux, G.; Baute, R.; Baute, M.-A.; Neven, A. A new metabolite produced by the fungus corticium caeruleum (sehrad.ex.Fr.) Fr. (Aphyllophorales): Cortciolic acid, isolation and chemical structure. C. R. Hebd. Seances Acad. Sci. Ser. D 1979, 288, 647-649.

32. Robinson, J. E.; Brimble M. A. The first enantioselective total synthesis of the anti-Helicobacter pylori agent (+)-spirolaxine methyl ether. Chem. Commun. 2005, 1560-1562.

33. Gauthier, D. R., Jr.; Carreira, E. M. Catalytic, enantioselective addition of allylsilanes to aldehydes: generation of a novel, reactive $\mathrm{Ti}^{\mathrm{IV}}$ complex from $\mathrm{TiF}_{4}$. Angew. Chem., Int. Ed. 1996, $35,2363-2365$.

34. Cotterill, A. S.; Gill, M.; Gimenez, A.; Milanovic, N. M. Pigments of fungi. Part 38. Synthesis of austrocorticinic acid and (S)-(-)-austrocorticin; absolute stereochemistry of natural austrocorticin. J. Chem. Soc. Perkin Trans. 1 1994, 1, 3269-3276.

35. The effect of LiBr on acetylide addition reactions has been noted: Van Rijn, P. E.; Mommers, S.; Visser, R. G.; Verkruijsse, H. D.; Brandsma, L. An efficient one-spot procedure for methyl ethers derived from tertiary acetylenic alcohols: strong influence of lithium bromide upon the coupling between propynyl lithium and cyclopentanone or cyclohexanone. Synthesis 1981, 459460

36. Blakemore, P. R. The modified Julia olefination: alkene synthesis via the condensation of metallated heteroarylalkylsulfones with carbonyl compounds. J. Chem. Soc. Perkin Trans. 1 2002, 2563-2585. 
37. Ley, S. V.; Humphries, A. C.; Eick, H.; Downham, R.; Ross, A. R.; Boyce, R. J.; Pavey, J. B. J.; Pietruszka, J. Total synthesis of the protein phosphatase inhibitor okadaic acid. J. Chem. Soc., Perkin Trans. 1, 1998, 3907-3912.

38. Nannei, R.; Dallavalle, S.; Merlini, L.; Bava, A.; Nasini, G. Synthesis of (+)-spirolaxine methyl ether. J. Org. Chem. 2006, 71, 6277-6280.

39. Arundale, E.; Mikeska, L. A. The olefin-aldehyde condensation. The Prins reaction. Chem. Rev. 1952, 52, 505-555.

40. Brown, H. C.; Jadhav, P. K. Asymmetric carbon-carbon bond formation via $\beta$-allyldiisopinocamphenylborane. Simple synthesis of secondary homoallylic alcohols with excellent enantiomeric purities. J. Am. Chem. Soc. 1983, 105, 2092-2093.

41. Coppi, L.; Ricci, A.; Taddei, M. Lewis acid-mediated condensation of alkenols and aldehydes. A selective synthesis of tetrahydropyrans and oxepanes. J. Org. Chem. 1988, 53, 911-913.

42. Dallallavalle, S.; Merlini, L.; Nannei, R.; Nasini, G.; Bava, A. A synthetic approach to sporotricale methylether. Synlett, 2005, 17, 2676-2678.

43. Keaton, K. A.; Phillips, A. J. Cyclopropanol-based strategy for subunit coupling: Total synthesis of (+)-spirolaxine methyl ether. J. Org. Lett. 2007, 9, 2717-2719.

44. Kulinkovich, O. G.; de Meijere, A. 1,n-Dicarbanionic titanium intermediates from monocarbanionic organometallics and their application in organic synthesis. Chem. Rev. 2000, 100, 2789-2834.

45. Netherton, M. R.; Dai, C.; Neuschutz, K.; Fu, G. C. Room-temperature alkyl-alkyl Suzuki crosscoupling of alkyl bromides that possess beta hydrogens. J. Am. Chem. Soc. 2001, 123, 10099100100 .

46. Dekker, K. A.; Inagaki, T.; Gootz, T. D.; Kaneda, K.; Nomura, E.; Sakakibara, T.; Sakemi, S,; Sugie, Y.; Yamauchi, Y.; Yoshikawa, N.; Kojima, N. CJ-12,954 and its congeners, new antiHelicobacter pylori compounds produced by Phanerochaete velutina: fermentation, isolation, structural elucidation and biological activities. J. Antibiot. 1997, 50, 833-839.

47. Brimble, M. A.; Bryant, C. J. Synthesis of the spiroacetal-containing anti-Helicobacter pylori agents CJ-12,954 and CJ-13,014. Chem. Commun. 2006, 4506-4508.

48. Corey, E. J.; Bakshi, R. K.; Shibata, S.; Chen, C.-P.; Singh, V. K. A stable and easily prepared catalyst for the enantioselective reduction of ketones. Applications to multistep syntheses. J. Am. Chem. Soc. 1987, 109, 7925-7926.

49. Freeman, F.; Kim, D. S. H. L.; Rodriguez, E. Preparation of 1,4-diketones and their reactions with bis(trialkyltin) or bis(triphenyltin) sulfide-boron trichloride. J. Org. Chem. 1992, 57, 17221727.

50. Blakemore, P. R. The modified Julia olefination: alkene synthesis via the condensation of metallated heteroarylalkylsulfones with carbonyl compounds. J. Chem. Soc. Perkin Trans. 1 2002, 2563-2585.

51. Álvarez-Bercedo, P.; Falomir, E.; Carda, M.; Marco, J. A. Enantioselective synthesis and absolute configurations of aculeatins A, B, D and 6-epi-aculeatin D. Tetraherdon 2006, 62, 9641-9649.

52. Ronald, R. C.; Wheeler, C. J. Synthesis of the simple flavonoid broussonin A. J. Org. Chem. 1984, 49, $1658-1660$. 
53. For review see: Ramachandran, P.V. Pinane-based versatile "allyl" boranes. Aldrichimica Acta 2002, 35, 23-35.

54. Tsuji, J. Comprehensive Organic Synthesis; Trost, B. M., Fleming, I., Winterfeldt, E., Eds.; Pergamon: Oxford, UK, 1993; Vol. 7, pp. 449-468.

55. Cowden, C. J.; Paterson, I. Organic Reactions; Paquette, L. A., Ed.; Wiley: New York, USA, 1997; Vol. 51, pp 1-200.

56. The addition step of the enolborane of $\beta$-alkoxy methyl ketone $\mathbf{1 0 1}$ to $n$-tetradecanal takes place with complete stereoselectivity, which reflects a high anti-1,5-induction. Paterson, I.; Gibson, K. R.; Oballa, R. M. Remote, 1,5-anti stereoinduction in the boron-mediated aldol reactions of $\beta$ oxygenated methyl ketones. Tetrahedron Lett. 1996, 37, 8585-8588.

57. Wong, Y-S. Synthesis of ( \pm )-aculeatins A and B. Chem. Commun. 2002, 686-687.

58. Moriarty, R. M. Organohypervalent iodine: Development, applications, and future directions. $J$. Org. Chem. 2005, 70, 2893-2903.

59. Evans, D. A.; Chapman, K. T.; Carreira, E. M. Directed reduction of $\beta$-hydroxy ketones employing tetramethylammonium triacetoxyborohydride. J. Am. Chem. Soc. 1988, 110, 35603578.

60. Scheidt, K. A.; Chen, H.; Follows, B. C.; Chemler, S. R.; Coffey, D. S.; Roush, W. R. Tris(dimethylamino)sulfonium difluorotrimethylsilicate, a mild reagent for the removal of silicon protecting groups. J. Org. Chem. 1998, 63, 6436-6437.

61. Chandrasekhar, S.; Rambabu, C.; Shyamsunder, T. Total synthesis of aculeatins A and B via a tethered oxa-Michael approach. Tetrahedron Lett. 2007, 48, 4683-4685.

62. Hanawa, H.; Hashimoto, T.; Maruoka, K. Bis(((S)-binaphthoxy)(isopropoxy)titanium) oxide as a $\mu$-oxo-type chiral Lewis acid: application to catalytic asymmetric allylation of aldehydes. $J$. Am. Chem. Soc. 2003, 125, 1708-1709.

63. Evans, D. A.; Gouchet-Prunet, J. A. Diastereoselective synthesis of protected syn 1,3-diols by base-catalyzed intramolecular conjugate addition of hemiacetal-derived alkoxide nucleophiles. $J$. Org. Chem. 1993, 58, 2446-2453.

64. Zhadankin, V. V.; Stang, P. J. Recent developments in the chemistry of polyvalent iodine compounds. Chem. Rev. 2002, 102, 2523-2584.

65. Peuchmaur, M.; Wong, Y.-S. Diastereoconvergent strategies for the synthesis of homochiral aculeatins. J. Org. Chem. 2007, 72, 5374-5379.

66. Nokami, J.; Ohga, M.; Nakamoto, H.; Matsubara, T.; Hussain, I.; Kataoka, K. The first and highly enantioselective crotylation of aldehydes via an allyl-transfer reaction from a chiral crotyl-donor. J. Am. Chem. Soc. 2001, 123, 9168-9169.

67. Wiseman, J. M.; McDonald, F. E.; Liotta, D. C. 1-Deoxy-5-hydroxysphingolipids as new anticancer principles: An Efficient Procedure for stereoselective syntheses of 2-amino-3, 5-diols. Org. Lett. 2005, 7, 3155-3157.

68. Vongvilai, P.; Isaka, M.; Kittakoop, P.; Prasert Srikitikulchai, P.; Kongsaeree, P.; Thebtaranonth, Y. Ketene acetal and spiroacetal constituents of the marine fungus Aigialus parvus BCC 5311.J. Nat. Prod. 2004, 67, 457-460. 
69. Isaka, M.; Suyarnsestakorn, C.; Tanticharoen, M.; Kongsaeree, P.; Thebtaranonth, Y. Aigialomycins A-E, New resorcylic macrolides from the marine mangrove fungus Aigialus parvus. J. Org. Chem. 2002, 67, 1561-1566.

70. Tanaka, H.; Nishida, K.; Sugita, K.; Yoshioka, T. Antitumor efficacy of hypothemycin, a new Ras-signaling inhibitor. Jpn. J. Cancer Res. 1999, 90, 1139-1145.

71. Figueroa, R.; Hsung, R. P.; Guevarra, C. C. An enantioselective total synthesis of (+)Aigialospirol. Org. Lett. 2007, 9, 4857-4859.

72. Hansen, T. V. Synthesis of (R)-(-)-argentilactone. Tetrahedron: Asymmetry 2002, 13, 547-550.

73. Khalaf, J. K.; Datta, A. Stereoselective route to the ezoaminuroic acid core of the ezomycins. $J$. Org. Chem. 2005, 70, 6937-6940.

74. Sakakura, A.; Suzuki, K.; Nakano, K.; Ishihara, K. Chiral 1,1'-binaphthyl-2,2'-diammonium salt catalysts for the enantioselective Diels-Alder reaction with -acyloxyacroleins. Org. Lett. 2006, 8, 2229-2232.

75. Ko, C.; Hsung, R. P. An unusual stereoselectivity in the anomeric substitution with carbamates promoted by HNTf 2 . Org. Biomol. Chem. 2007, 7, 431-434.

76. Trnka, T. M.; Grubbs, R. H. The development of $\mathrm{L}_{2} \mathrm{X}_{2} \mathrm{Ru}=\mathrm{CHR}$ olefin metathesis catalysts: An organometallic success story. Acc. Chem. Res. 2001, 34, 18-29.

77. Snieckus, V. Directed ortho metalation. Tertiary amide and O-carbamate directors in synthetic strategies for polysubstituted aromatics. Chem. Rev. 1990, 90, 879-933.

78. Selles, P.; Lett, R. Convergent stereospecific synthesis of C292 (or LL-Z1640-2), and hypothemycin. Part 1. Tetrahedron Lett. 2002, 43, 4621-4625.

79. Bez, G.; Bezbarua, M. S.; Saikia, A. K.; Barua, N. C. Short enantioselective syntheses of both 2,7-dimethyl-1,6-dioxaspiro[4.6]undecane and 2,7-diethyl-1,6-dioxaspiro[4.6]undecane using functionalized nitroalkane synthons. Synthesis 2000, 4, 537 - 540.

80. Francke, W.; Reith, W.; Bergstrom, G.; Tengoe, J. Pheromone bonquet of the mandibular glands in adrenahaemorrhoa F (Hym., Apoida). Z. Naturforsch. Teil C 1981, 36, 928-932.

81. Bergstroem, G.; Tengoe, J.; Reith, W.; Francke, W. Multicomponent mandibular gland secretions in three species of Andrena bees (Hym., Apoida). Z. Naturforsch., C, J. Biosci. 1982, 37C, 1124-1129.

82. Saikia, A. K.; Hazarika, M. J.; Barua, N. C. Bezbarua, Maitreyee S. Sharma, R. P.; Ghosh, A. C. Direct synthesis of keto nitroaliphatics via retro-Henry reaction of cyclic 2-nitroalcohols by anhydrous copper sulfate adsorbed on silica gel. A short synthesis of $( \pm$ )-phoracantholide I. Synthesis 1996, 981-985.

83. Occhiato, E. G.; Guranna, A.; Descrlo, F.; Scarpi, D. Baker's yeast reduction of prochiral $\gamma$ nitroketones.II. straightforward enantioselective synthesis of 2,7-dimethyl-1,6dioxaspiro[4.4]nonanes. Tetrahedron: Asymmetry 1995, 6, 2971-2976.

84. Ghosh, S. K.; Hsung, R. P.; Wang, J. Ketal-tethered ring-closing metathesis. An unconventional approach to constructing spiroketals and total synthesis of an insect pheromone. Tetrahedron Lett. 2004, 45, 5505-5510.

85. Tengoe, J.; Bergstroem, G.; Borg-Karlson, A. K.; Groth, I.; Francke, W. Volatile compounds from cephalic secretions of females in two cleptoparacite bee genera, Epeolus (Hym., 
Anthophoridea) and Coelioxys (Hym.' Megachilidae). Z. Naturforsch., C, J. Biosci. 1982, 37, 376-380.

86. Isaksson, R.; Liljefors, L.; Reinholdsson, P. Preparative separation of the enantiomers of trans,trans- and cis,trans-2,8-dimethyl-1,7-dioxaspiro[5.5]undecane, main pheromone components of Adrena bees, by liquid chromatography on triacetycellulose. J. Chem. Soc. Chem. Commun. 1984, 137-138.

87. Boeckman, R. K., Jr.; Bruza, K. J. A simplified isoquinoline synthesis. Tetrahedron 1981, 37, 39-97.

88. Ballini, R.; Bosica, G.; Schaafstra, R. Nitroketones in organic synthesis: a new short synthesis of racemic trans 2-methyl-1,7-dioxaspiro[5.5] undecane, trans, trans-and trans, cis-2,78-dimethyl1,7-dioxaspiro[5.5] undecane by Henry reaction. Liebig Ann. chem. 1994, 1235-1237;

89. Weber, G. F.; Hall, S. S. The chemistry of 2-alkoxy-3, 4-dihydro-2H-pyrans. 7. Effect of substituents on the reactivity of various alkyl- and phenyl-substituted 3, 4-dihydro-2H-pyrans with tert-butyl hypochlorite. J. Org. Chem. 1979, 44, 364-368.

90. Takahashi, H.; Osada, H.; Koshino, H.; Kudo, T.; Amano, S.; Shimizu, S.; Yoshihama, M.; Isono, K. Reveromycins, new inhibitors of eukaryotic cell growth. J. Antibiot. 1992, 45, 14091413.

91. Miyamoto, Y.; Machida, K.; Mizunuma, M.; Emoto, Y.; Sato, N.; Miyahara, K.; Hirata, D.; Usui, T.; Takahashi, H.; Osada, H.; Miyakawa, T. Identification of saccharomyces cerevisiae isoleucyl-tRNA synthetase as a target of the $\mathrm{G}_{1}$-specific inhibitor reveromycin A. J. Biol. Chem. 2002, 277, 28810-28814

92. Sous, M. E.; Ganame, D.; Tregloan, P. A.; Rizzacasa, M. A. Total synthesis of (-)-reveromycin A. Org. Lett. 2004, 6, 3001- 3004.

93. Bednarski, M.; Danishefsky, S. J. Mild Lewis acid catalysis: tris(6,6,7,7,8,8,8- heptafluoro-2,2dimethyl-3,5-octanedionato)europium-mediated hetero-Diels-Alder reaction. J. Am. Chem. Soc. 1983, 105, 3716-3717.

94. Cuzzupe, A. N.; Hutton, C. A.; Lilly, M. J.; Mann, R. K.; Rizzacasa, M. A.; Zammit, S. C. Total synthesis of (-)-reveromycin B. Org. Lett. 2000, 2, 191-194.

95. Dess, D. B.; Martin, J. C. A useful 12-I-5 triacetoxyperiodinane (the Dess-Martin periodinane) for the selective oxidation of primary or secondary alcohols and a variety of related 12-I-5 species. J. Am. Chem. Soc. 1991, 113, 7277-7287.

96. Nagao, Y.; Hagiwara, Y.; Kumagi, T.; Ochiai, M.; Inoue, T.; Hashimoto, K.; Fujita, E. New C-4chiral 1, 3-thiazolidine-2-thiones: excellent chiral auxiliaries for highly diastereo-controlled aldol-type reactions of acetic acid and $\alpha, \beta$-unsaturated aldehydes. J. Org. Chem. 1986, 51, 23912393.

97. Cuzzupe, A. N.; Hutton, C. A.; Lilly, M. J.; Mann, R. K.; McRae, K. J.; Rizzacasa, M. A.; Zammit, S. C. Total synthesis of the epidermal growth factor inhibitor (-)-reveromycin B. J. Org. Chem. 2001, 66, 2382-2393.

98. Zhang, H. X.; Guibe, F.; Balavoine, G. Palladium- and molybdenum-catalyzed hydrostannation of alkynes. A novel access to regio- and stereodefined vinylstannanes. J. Org. Chem. 1990, 55, 1857-1867. 
99. Hungerbuhler, E.; Seebach, D.; Wasmuth, D. Enantiomerically pure synthetic building blocks with four C-atoms and two or three functional groups from $\beta$-hydroxybutanoic, malic, and tartaric acids. Helv. Chim. Acta 1981, 64, 1467-1487.

100. Shimizu, T.; Masuda, T.; Hiromoto, K.; Nakata, T. Total synthesis of reveromycin A. Org. Lett. 2000, 2, 2153-2156.

101. Shimizu, T.; Kobayashi, R.; Ohmori, H, Nakata, T. Synthesis of dicarboxylic monoesters with cyclic anhydrides under high pressure. Synlett 1995, 650-652.

102. Tsunoda, T.;Yamamiya, Y.; Yumi Kawamura, Y.; Itô, S. Mitsunobu acylation of sterically congested secondary alcohols by $N, N, N^{\prime}, N^{\prime}$-tetramethylazodicarboxamide-tributylphosphine reagents. Tetrahedron Lett. 1995, 36, 2529-2530.

103. Baudin, J. B.; Hareau, G.; Julia, S. A. Ruel, O. Stereochemistry of the olefin formation from anti and syn heterocyclic $\beta$-hydroxy sulfones. Bull. Soc. Chim. Fr. 1993, 130, 336-357.

104. McRae, K. J.; Rizzacasa, M. A. Synthetic Studies toward the reveromycins: Asymmetric synthesis of the spiroketal segment of reveromycin B. J. Org. Chem. 1997, 62, 1196-1197.

105. Cuzzupe, A. N.; Hutton, C. A.; Lilly, M. J.; Mann, R. K.; Rizzacasa, M. A.; Zammit, S. C. Total synthesis of (-)-reveromycin B, Org. Lett. 2000, 2, 191-192.

106. McRae, K. J.; Rizzacasa, M. A. Synthetic studies toward the reveromycins: Asymmetric synthesis of the spiroketal segment of reveromycin B. J. Org. Chem. 1997, 62, 1196-1197.

107. Murray, R. W.; Jeyaraman, R. J. Dioxiranes: synthesis and reactions of methyldioxiranes. J. Org. Chem. 1985, 50, 2847-2853.

108. Zhang, H. X.; Guibe, F.; Balavoine, G. Palladium- and molybdenum-catalyzed hydrostannation of alkynes. A novel access to regio- and stereodefined vinylstannanes. J. Org. Chem. 1990, 55, 1857-1867.

109. LeNoble, W. J. The configurations of some substituted $\beta$-haloacyrlic acids. J. Am. Chem. Soc. 1961, 83, 3897-3899.

110. Farina, V.; Krishnan, B. Large rate accelerations in the Stille reaction with tri-2-furylphosphine and triphenylarsine as palladium ligands: mechanistic and synthetic implications. J. Am. Chem. Soc. 1991, 113, 9585-9595.

111. Guzzo, P. R.; Miller, M. J. Catalytic, Asymmetric synthesis of the carbacephem framework. $J$. Org. Chem. 1994, 59, 4862-4867.

112. Drouet, K. E.; Theodorakis, E. A. Enantioselective total synthesis of reveromycin B. J. Am. Chem. Soc. 1999, 121, 456-457.

113. Shimizu, T.; Kobayashi, R.; Osaka, K.; Osada, H.; Nakata, T. Synthetic studies on reveromycin A: Stereoselective synthesis of the spiroketal system. Tetrahedron Lett. 1996, 37, 6755-6758.

114. Corey, E. J.; Fuchs, P. L. A synthetic method for formyl $\rightarrow$ ethynyl conversion $(\mathrm{RCHO} \rightarrow \mathrm{RC} \equiv$ $\mathrm{CH}$ or $\left.\mathrm{RC} \equiv \mathrm{CR}^{\prime}\right)$. Tetrahedron Lett. 1972, 3769-3772.

115. Evans, D. A.; Ennis, M. D.; Mathre, D. J. Asymmetric alkylation reactions of chiral imide enolates. A practical approach to the enantioselective synthesis of alpha.-substituted carboxylic acid derivatives. J. Am. Chem. Soc. 1982, 104, 1737-1739.

116. Negishi, E.; Okukado, N.; King, A. O.; Van, Horn, D. E.; Spiegel, B. I. Selective carbon-carbon bond formation via transition metal catalysts. 9. Double metal catalysis in the cross-coupling 
reaction and its application to the stereo- and regioselective synthesis of trisubstituted olefins. $J$. Am. Chem. Soc. 1978, 100, 2254-2256.

117. Panek, J. S.; Hu, T. Stereo- and Regiocontrolled synthesis of branched trisubstituted conjugated dienes by palladium(0)-catalyzed cross-coupling reaction. J. Org. Chem. 1997, 62, 4912-4913.

118. Kishi, Y. Applications of nickel(II)/chromium(II)-mediated coupling reactions to natural products syntheses. Pure Appl. Chem. 1992, 64, 343-350.

119. Masuda, T.; Osaka, K.; Shimizu, T.; Nakata, T. Total synthesis of reveromycin B. Org. Lett. 1999, 1, 941-944.

120. Carlsen, P. H. J.; Katsuki, T.; Martin, V. S.; Sharpless, K. B. A greatly improved procedure for ruthenium tetroxide catalyzed oxidations of organic compounds. J. Org. Chem. 1981, 46, 39363938.

121. Shimizu, T.; Osaka, K.; Nakata, T. Reactions of perfluoro-1-chloro-2-trimethylsilylcyclobutene. Tetrahedron Lett. 1997, 38, 1685-2688.

122. Evans, D. A.; Bartoli, J.; Shih, T. L. Enantioselective aldol condensations. 2. erythro-selective chiral aldol condensations via boron enolates. J. Am. Chem. Soc. 1981, 103, 2127-2129.

123. Tsuji, J.; Minami, I.; Shimizu, I. Preparation of 1-alkenes by the palladium-catalyzed hydrogenolysis of terminal allylic carbonates and acetates with formic acid-triethylamine. Synthesis 1986, 623-627.

124. Gouiffes, D.; Moreau, S.; Helbecque, N.; Bernier, J. L.; Henichart, J. P.; Barbin,Y.; Laurent, D.; Verbist, J. F. Proton nuclear magnetic study of bistramide A, a new cytotoxic drug isolated from Lissoclinum Bistratum Sluiter. Tetrahedron 1988, 44, 451-459.

125. Riou, D.; Roussakis, C.; Robillard, N.; Biard, J. F.; Verbist, J. F. Bistramide A-induced irreversible arrest of cell proliferation in a non-small-cell bronchopulmonary carcinoma is similar to induction of terminal maturation. Biol. Cell. 1993, 77, 261-264.

126. Sauviat, M. P.; Gouiffes-Barbin, D.; Ecault, E.; Verbist, J. F. Blokage of sodium channels by bistramide A in voltage-clamped frog skeletal muscle fibres. Biochim. Biophys. Acta 1992, 1103, 109-114.

127. Freya, M. R.; Leontieva, O.; Watters, D. J.; Black, J. D. Stimulation of protein kinase Cdependent and -independent signaling pathways by bistratene A in intestinal epithelial cells. Biochem. Pharm. 2001, 61, 1093-1100.

128. Wipf, P.; Hopkins, T. D. Total synthesis and structure validation of (+)-bistramide C. Chem. Commun. 2005, 3421-3423.

129. Novak, T.; Tan, Z.; Liang, B.; Negishi, E. All-catalytic, efficient, and asymmetric synthesis of $\alpha, \omega$-diheterofunctional reduced polypropionates via "One-Pot" Zr-catalyzed asymmetric carboalumination-Pd-catalyzed cross-coupling tandem process. J. Am. Chem. Soc. 2005, 127, 2838-2839.

130. Evans, P. A.; Cui, J.; Gharpure, S. J.; Hinkle, R. J. Stereoselective construction of cyclic ethers using a tandem two-component etherification: Elucidation of the role of bismuth tribromide. $J$. Am. Chem. Soc. 2003, 125, 11456-11457.

131. Wipf, P.; Uto, Y.; Yoshimura, S. Total synthesis of a stereoisomer of bistramide $\mathrm{C}$ and assignment of configuration of the natural product. Chem. Eur. J. 2002, 8, 1670-1681. 
132. Lipshutz, B. H.; Elworthy, Intermolecular couplings between vinyl triflates and allylic cuprates: a mild and rapid atypical route to 1,4-dienes. J. Org. Chem. 1990, 55, 1695-1696.

133. Nelson, S. G.; Peelen, T. J.; Wan, Z. Catalytic asymmetric acyl halide-aldehyde cyclocondensations. A strategy for enantioselective catalyzed cross aldol reactions. J. Am. Chem. Soc. 1999, 121, 9742-9743.

134. Dorta, R. L.; Martin, A.; Salazar, J. A.; Suarez, E.; Prange, T. An enantioselective synthesis of D-(-)-2-amino-5-phosphonopentanoic acid. J. Org. Chem. 1998, 63, 2251-2261.

135. Broka, C. A.; Ehrler, J. Enantioselective total syntheses of bengamides B and E. Tetrahedron Lett. 1991, 32, 5907-5910.

136. Tanaka, N.; Suenaga, K.; Yamada, K.; Shu-zhen Zheng, S.-Z.; Chen, H.-S.; and Daisuke Uemura, D. Isolation and structures of attenols A and B. Novel bicyclic triols from the chinese bivalve Pinna attenuata. Chem. Lett. 1999, 1025-1026.

137. Weghe P. V. de.; Aoun, D.; Boiteau, J.-G.; Eustache, J. Silicon tether-aided coupling metathesis: Application to the synthesis of attenol A. Org. Lett. 2002, 4, 4105-4108.

138. Oikawa, M.; Ueno, T.; Oikawa, H.; Ichihara, A. Total synthesis of tautomycin. J. Org. Chem. 1995, 60, 5048-5068.

139. Rychnovsky, S. D.; Griesgraber, G. Zeller, S.; Skalitzky, D. J. Optically pure 1,3-diols from $(2 R, 4 R)$ - and (2S,4S)-1,2:4,5-diepoxypentane. J. Org. Chem. 1991, 56, 5161-5169.

140. Jung, M. E.; Karama, U.; Marquez, R. Conversion of homoallylic alcohols with alkene protection to the corresponding methyl ketones. J. Org. Chem. 1999, 64, 663-665.

141. Enders, D.; Lenzen, A.; Asymmetric total synthesis of attenol A and B. Synlett 2003, 2185-2187.

142. Job, A.; Janeck, C. F.; Bettray, W.; Peters, R.; Enders, D. The SAMP-/RAMP-hydrazone methodology in asymmetric synthesis. Tetrahedron 2002, 58, 2253-2329.

143. Kolb, H. C.; VanNieuwenhze, M. S.; Sharpless, K. B. Catalytic asymmetric dihydroxylation. Chem. Rev. 1994, 94, 2483.

144. Suenaga, K.; Araki, K.; Sengoku, T.; Uemura, D. Enantioselective synthesis of attenols A and B. Org. Lett. 2001, 3, 527-529.

145. Posner, G. H.; Weitzberg, M.; Hamill, T. G.; Asirvatham, E.; Cun-heng, H.; Clardy, J. Asymmetric michael additions of ester enolates to enantiomerically pure vinylic sulfoxides: synthesis of 3-substituted glutarate esters in high enantiomeric purity. Tetrahedron 1986, 42, 2919-2929.

146. La Cruz, T. E.; Rychnovsky, S. D. A reductive cyclisation approach to attenol A. J. Org. Chem. 2007, 72, 2602-2611.

147. Takaoka, L. R.; Buckmelter, A. J.; La Cruz, T. E.; Rychnovsky, S. D. Rational synthesis of contra-thermodynamic spiroacetals by reductive cyclizations J. Am. Chem. Soc. 2005, 127, 528529.

148. Schaus, S. E.; Brandes, B. D.; Larrow, J. F.; Tokunaga, M.; Hansen, K. B.; Gould, A. E.; Furrow, M. E.; Jacobsen, E. N. Highly selective hydrolytic kinetic resolution of terminal epoxides catalyzed by chiral (salen)Co ${ }^{\text {III }}$ complexes. Practical synthesis of enantioenriched terminal epoxides and 1,2-diols. J. Am. Chem. Soc. 2002, 124, 1307-1315.

149. Schneider, C.; Klapa, K.; Hansch, M. Zr (Ot-Bu) 4-catalyzed Tishchenko reduction of $\beta$-hydroxy ketones. Synlett 2005, 91-95. 
150. Takami, K.; Yorimitsu, H.; Oshima, K. Trans-Hydrometalation of Alkynes by a Combination of $\mathrm{InCl}_{3}$ and DIBALH: One-pot access to functionalized (Z)-alkenes. Org. Lett. 2004, 4, 2993-2995.

151. Louie, J.; Bielawski, C. W.; Grubbs, R. H. Tandem Catalysis: The sequential mediation of olefin metathesis, hydrogenation, and hydrogen transfer with single-component Ru complexes. J. Am. Chem. Soc. 2001, 123, 11312-11313.

152. Milne, J. E.; Kocienski, P. J. A Synthesis of $\alpha$-lithiated enol ethers from $\alpha$-arenesulfinyl enol ethers: $\mathrm{Ni}(0)$ - and $\mathrm{Pd}(0)$-catalysed coupling of enol triflates and phosphates derived from lactones with sodium arenethiolates gives $\alpha$-arenesulfanyl enol ethers. Synthesis 2003, 584-592.

153. Calaza, M. I.; Hupe, E.; Knochel, P. Highly anti-Selective $S_{N} 2$ ' Substitutions of chiral cyclic 2iodo-allylic alcohol derivatives with mixed zinc-copper reagents. Org. Lett. 2003, 5, 1059-1061.

154. Guijarro, D.; Mancheno, B.; Yus, M. Direct transformation of trialkyl phosphates into organolithium compounds by a DTBB-catalysed lithiation. Tetrahedron 1994, 50, 8551-8558.

155. Kolb, H. C.; Sharpless, K. B. A simplified procedure for the stereospecific transformation of 1,2diols into epoxides. Tetrahedron 1992, 48, 10515-10530.

156. Statsuk, A. V.; Bai, R.; Baryza, J. L.; Verma, V. A.; Hamel, E.; Wender, P. A.; Kozmin, S. A. Actin is the primary cellular recepter of bistramide A. Nat. Chem. Biol. 2005, 1, 383-388.

157. Yadav, J. S.; Chetia, L. Stereoselective total synthesis of bistramide A. Org. Lett. 2007, 9, 45874589.

158. Yadav, J. S.; Joyasawal, S.; Dutta, S. K.; Kunwar, A. C. Stereoselective synthesis of the ABCD ring framework of azaspiracids. Tetrahedron Lett. 2007, 48, 5335-5340

159. Yadav, J. S.; Gadgil, V. R. Effect of substituents on radical induced cyclization of bromoacetals of 3-hydroxyhexa-1,5-dienes. J. Chem. Soc. Chem. Commun. 1989, 1824-1825.

160. Smith, A. B., III; Condon, S. M.; McCauley, J. A.; Leazer, J. L., Jr.; Leahy, J. W.; Maleczka, R. E., Jr. A unified total synthesis of the immunomodulators (-)-rapamycin and (-)-27-demethoxyrapamycin: Construction of the C (21-42) Perimeters. J. Am. Chem. Soc. 1997, 119, 947-961.

161. Yadav, J. S.; Gadgil, V. R. TosMIC in the preparation of spiroacetals: synthesis of pheromone components of olive fruit fly. Tetrahedron Lett. 1990, 31, 6217-6218.

162. Paterson, I.; Yeung, K. S.; Smaill, J. B. The Horner-Wordsworth-Emmons reaction in natural product synthesis: Expedient construction of complex (E)-enones using barium hydroxide. Synlett. 1993, 774-776.

163. Corey, E. J.; Helal, C. J. Reduction of carbonyl compounds with chiral oxazaborolidine catalysts: A new paradigm for enantioselective catalysis and a powerful new synthetic method.Angew. Chem. Int. Ed. Engl. 1998, 37, 1986-2012.

164. Lowe, J. T.; Wrona, I. E.; Panek, J. S. Total synthesis of bistramide A. Org. Lett. 2007, 9, $327-$ 330.

165. Evans, D. A.; Downey, C. W.; Shaw, J. T.; Tedrow, J. S. Magnesium halide-catalyzed anti-aldol reactions of chiral N-acylthiazolidinethiones. Org. Lett. 2002, 4, 1127-1130.

166. Basha, A.; Lipton, M.; Weinreb, S. M. A mild, general method for conversion of esters to amides. Tetrahedron Lett. 1977, 18, 4171-4172.

167. Schomaker, J. M.; Pulgam, V. R.; Borhan, B. Synthesis of diastereomerically and enantiomerically pure 2,3-disubstituted tetrahydrofurans using a sulfoxonium ylide. J. Am. Chem. Soc. 2004, 126, 13600-13601. 
168. Miyashita, M.; Hoshino, M.; Yoshikoshi, A. Stereospecific methylation of $\gamma, \delta$-epoxy acrylates by trimethyl aluminum: a method for the iterative construction of polypropionate chains. J. Org. Chem. 1991, 56, 6483-6485.

169. Crimmins, M. T.; DeBaillie, A. C. Enantioselective total synthesis of bistramide A. J. Am. Chem. Soc. 2006, 128, 4936-4937.

170. Kopecky, D. J.; Rychnovsky, S. D. Improved procedure for the reductive acetylation of Acyclic esters and a new synthesis of ethers. J. Org. Chem. 2000, 65, 191-198.

171. Statsuk, A. V.; Liu, D.; Kozmin, S. A. Synthesis of bistramide A. J. Am. Chem. Soc. 2004, 126, 9546-9547.

172. Bringer, P.; Muller, B. R.; Mynott, R. Vinylcarbene complexes of titanocene. Angew. Chem., Int. Ed. Engl. 1989, 28, 610-611.

173. Scholl, M.; Ding, S.; Lee, C. W.; Grubbs, R. H. Synthesis and Activity of a New Generation of Ruthenium-Based Olefin Metathesis Catalysts Coordinated with 1,3-Dimesityl-4,5dihydroimidazol-2-ylidene Ligands. Org. Lett. 1999, 1, 953-956.

174. Barma, D. K.; Kundu, A.; Zhang, H. M.; Mioskowski, C.; Falck, J. R. (Z)- $\alpha$-Haloacrylates: An exceptionally stereoselective preparation via $\mathrm{Cr}(\mathrm{II})$-mediated olefination of aldehydes with trihaloacetates. J. Am. Chem. Soc. 2003, 125, 3218-3219.

175. Corey, E. J.; Helal, C. J. Reduction of carbonyl compounds with chiral oxazaborolidine catalysts: A new Paradigm for enantioselective catalysis and a powerful new synthetic method. Angew. Chem. Int. Ed. Engl. 1998, 37, 1986-2012.

176. Brown, H. C.; Bhat, K. S. Enantiomeric Z- and E-crotyldiisopinocampheylboranes. Synthesis in high optical purity of all four possible stereoisomers of $\beta$-methylhomoallyl alcohols. J. Am. Chem. Soc. 1986, 108, 293.

177. Crimmins, M. T.; DeBaillie, A. C. Enantioselective total synthesis of bistramide A. J. Am. Chem. Soc. 2006, 128, 4936-4937.

178. Crimmins, M. T.; King, B. W.; Tabet, E. A.; Chaudhary, K. Asymmetric Aldol Additions: Use of titanium tetrachloride and (-)-sparteine for the soft enolization of $\mathrm{N}$-acyl oxazolidinones, oxazolidinethiones, and thiazolidinethiones. J. Org. Chem. 2001, 66, 894-902.

179. Lowe, J. T.; Wrona, I. E.; Panek, J. S. Total synthesis of bistramide A. Org. Lett. 2007, 9, $327-$ 330 .

180. Huang, H.; Panek, J. S. Stereoselective synthesis of functonalized dihydropyrans via a formal [4+2]-annulation of chiral crotylsilanes. J. Am. Chem. Soc. 2000, 122, 9836.

181. Cloarec, J.-M.; Charette, A. B. Highly efficient two-step synthesis of C-sp ${ }^{3}$-centered geminal diiodides. Org. Lett. 2004, 6, 4731-4734.

182. Holtzel, A.; Kempter, C.; Metzger, J. W.; Jung, G.; Groth, I.; Fritz, T.; Fiedler, H.-P. Spirofungin, a new antifungal antibiotic from Streptomyces violaceusniger. J. Antibiot. 1998, 51, 699-707.

183. Takahashi, H.; Osada, H.; Koshino, H.; Kudo, T.; Amano, S.; Shimizu, S.; Yoshihama, M.; Isono, K. Revermycins, new inhibitors of eukaryotic cell growth. J. Antibiot. 1992, 45, 14091413. 
184. Takahashi, H.; Osada, H.; Koshino, H.; Sasaki, M.; Onose, R.; Nakakoshi, M.; Yoshihama, M.; Isono, K. Revermycins, new inhibitors of eukaryotic cell growth. J. Antibiot. 1992, 45, 14141419.

185. Koshino, H.; Takahashi, H.; Osada, H.; Isono, K. Reveromycins, new inhibitors of eukaryotic cell growth. J. Antibiot. 1992, 45, 1420-1427.

186. Ubukata, M.; Koshino, H.; Osada, H.; Isono, K. Absolute configuration of reveromycin A, an inhibitor of the signal transduction of epidermal growth factor. J. Chem. Soc., Chem. Commun. 1994, 1877-1878.

187. Shimizu, T.; Satoh, T.; Murakoshi, K.; Sodeoka, M. Asymmetric total synthesis of (-)spirofungin A and (+)-spirofungin B. Org. Lett. 2005, 7, 5573-5576.

188. Yamaguchi, M.; Hirao, I. An efficient method for the alkynylation of oxiranes using alkynyl boranes. Tetrahedron Lett. 1983, 24, 391-394.

189. Takai, K.; Nitta, K.; Utimoto, K. Simple and selective method for aldehydes (RCHO) $\longrightarrow$ (E)haloalkenes (RCH:CHX) conversion by means of a haloform-chromous chloride system. J. Am. Chem. Soc. 1986, 108, 7408-7410.

190. Takagi, J.; Takahashi, K.; Isiyama, T.; Miyaura, N. Palladium-catalyzed cross-coupling reaction of bis(pinacolato)diboron with 1-alkenyl halides or triflates: convenient synthesis of unsymmetrical 1,3-dienes via the borylation-coupling sequence. J. Am. Chem. Soc. 2002, 124, 8001-8006.

191. Corey, E. J.; Katzenellenbogen, J. A.; Roman, S. A.; Gilman, N. W. Stereospecific synthesis of a biologically active dehydro derivative of the $\mathrm{C}_{18}$-juvenile hormone of cecropia. New routes to a key $\mathrm{C}_{12}$-intermediate. Tetrahedron Lett. 1971, 21, 1821-1824.

192. Miyaura, N.; Suginome, H.; Suzuki, A. A stereospecific synthesis of conjugated (E,Z)- and (Z,Z)-alkadienes by a palladium-catalyzed cross-coupling reaction of 1-alkenylboranes with 1alkenyl bromides. Tetrahedron Lett. 1981, 22, 127-130.

193. Kato, y.; Kusetani, N.; Matsunaga, S.; Hashimoto, K.; Furuya, T. Bioactive marine metabolites. Part 16. Calyculin A. A novel antitumor metabolite from the marine sponge discodermia calyx. $J$. Am. Chem. Soc. 1986, 108, 2780-2781.

194. Evans, D. A.; Gage, J. R.; Leighton, J. L. Total synthesis of (+)-calyculin A. J. Am. Chem Soc. 1992, 114, 9434-9453.

195. Tanimoto, N.; Gerritz, S. W.; Sawabe, A.; Noda, T.; Filla, S. A.; Masamune, S. The synthesis of naturally occurring (-)-calyculin A. Angew. Chem. Int. Ed. Engl. 1994, 33, 673-675.

196. Yokokawa, F.; Hamada, Y.; Shioiri, T. Total synthesis of calyculin A: Construction of the C(9)C(37) fragment. J. Chem. Soc., Chem. Commun. 1996, 871-872.

197. Smith, A. B. III; Friestad, G. K.; Duan, J. J.-W,; Barbosa, J.; Hull, K. G.; Iwashima, M.; Qiu, Y.; Spoors, P. G.; Bertounesque, E.; Salvatore, B. A. Total synthesis of (+)-calyculin A and (-) calyculin B. J. Org. Chem. 1998, 63, 7596-7597.

198. Hyuga, S.; Chiba, Y.; Yamashina, N.; Hara. S.; Suzuki, A. (E)-(2-Bromoethenyl)dibromoborane. A New precursor for (E)-1, 2-disubstituted ethenes. Chem. Lett. 1987, 1757-1760.

199. Roush, W. R.; Palkowitz, A. D.; Ando, K. Acyclic diastereoselective synthesis using tartrate ester-modified crotylboronates. Double asymmetric reactions with $\alpha$-methyl chiral aldehydes and synthesis of the C(19)-C(29) segment of rifamycin S. J. Am. Chem. Soc. 1990, 112, 6348-6359. 
200. McMurry, J. E.; Scott, W. J. A method for the regiospecific synthesis of enol triflates by enolate trapping. Tetrahedron Lett. 1983, 24, 979-782.

201. Piers, E.; Tillyer, R. D. Dilithium (trimethylstannyl)(2-thienyl)(cyano)cuprate, a synthetically useful higher-order cuprate reagent. J. Org.Chem. 1988, 53, 5366-5369.

202. Smith, A. B., III; Salvatore, B. A.; Hull, K. G.; Duan J. J.-W. Calyculin synthetic studies. 2. Stereocontrolled assembly of the $C(9)-C(13)$ dithiane and $C(26)-C(37)$ oxazole intermediates. Tetrahedron Lett. 1991, 32, 4859-4862.

203. Salvatore, B. A.; Smith, A. B. III Calyculin synthetic studies. 3. Enantiomeric purity determination for the $\mathrm{C}(26)-\mathrm{C}(32)$ oxazole segment via the silks-odom ${ }^{77} \mathrm{Se}$ NMR method, Tetrahedron Lett. 1994, 35, 1329-1330.

204. Toshima, K.; Tatsuta, K.; Kinoshita, M. Total synthesis of elaiophylin (Azalomycin B). Bull. Chem. Soc. Jpn. 1988, 61, 2369-2381.

205. Lipshutz, B. H.; Sengupta, S. Organocopper reagents: substitutions, conjugate addition, carbo/metallocupration and other reactions. Org. React. 1992, 41, 135-631.

206. Smith, A. B., III; Iwashima, M. Calyculin synthetic studies. 4. Remarkable reversal of diastereoselectivity in payne epoxidation of vinyl spiroketal intermediates. Tetrahedron Lett. 1994, 35, 6051-6052.

207. Ley, S. V.; Norman, J.; Griffith, W. P.; Marsden, S. P. Tetrapropylammonium perruthenate, $\mathrm{Pr}_{4} \mathrm{~N}^{+} \mathrm{RuO}_{4}^{-}$, TPAP: A catalytic oxidant for organic synthesis. Synthesis 1994, 639-666.

208. Zhao, Z.; Scarlato, G. R.; Armstrong, R. W. Synthesis of trans-4-alkenyl oxazoles. Tetrahedron Lett. 1991, 32, 1609-1612.

209. Yamakado, Y.; Ishiguro, M.; Ikeda, N.; Yamamoto, H. Stereoselective carbonyl-olefination via organosilicon compounds. J. Am. Chem. Soc. 1981, 103, 5568-5570.

210. Huth, A.; Dettner, K. Defense chemicals from abdominal glands of 13 rove beetle species of subtribe staphylinina (Coleoptera: Staphylinidae, Staphylininae). J. Chem. Ecol. 1990, 16, 26912711.

211. Zhang, H.; Fletcher, M. T.; Dettner, K.; Francke, W.; Kitching, W. Synthesis and absolute stereochemistry of spiroacetals in rove beetles (Coleoptera: Staphylinidae). Tetrahedron Lett. 1999, 40, 7851-7854.

212. Bernardi, M. D.; Garlaschelli, L.; Toma, L.; Vidari, G,; Finzi, P. V. Fungal metabolites XXVI: The structure of saponaceolides B, C and D, new C-30 terpenoids from Tricholoma saponaceum. Tetrahedron 1991, 47, 7109-7116.

213. Vidari, G.; Lanfranchi, G.; Sartori, P.; Serra, S. Saponaceolides: differential cytotoxicity and enantioselective synthesis of the right-hand lactone moiety. Tetrahedron: Asymmetry 1995, 06, 2977-2990.

214. Trost, B. M.; Corte J. R. Total synthesis of (+)-saponaceolide B. Angew. Chem. Int. Ed. 1999, 38, 3664-3666.

215. Vidari, G.; Franzini, M.; Garlaschelli, L.; Maronati, A. diastereoselective synthesis of the saponaceolide tricyclic spiroketal substructure. Tetrahedron Lett. 1993, 34, 2685-2688.

216. Guertin, K. R.; Kende, A. S. Chemoselective catalytic oxidation of sulfides to sulfones with tetrapropylammonium perruthenate (TPAP). Tetrahedron Lett. 1993, 34, 5369-5372. 
217. Lynn, D. G.; Phillips, N. J.; Hutton, W. C.; Shabanowitz, J.; Fennell, D. I.; Cole, R. J. Talaromycins: application of homonuclear spin correlation maps to structure assignment. J. Am. Chem. Soc. 1982, 104, 7319-7322.

218. Izquierdo, I.; Plaza, M. T.; Rodríguez, M.; Tamayo, J. A. Hexulose derivatives and lipasemediated diastereomeric resolution in the enantiospecific total synthesis of (-)-talaromycins $\mathrm{C}$ and E. Eur. J. Org. Chem. 2002, 309-317.

219. Izquierdo, I.; Plaza, M. T. An enantiospecific synthesis of (-)-talaromycins A and B from Dfructose. Carbohydr. Res. 1990, 205, 293-304.

220. Izquierdo, I.; Plaza, M. T.; Rodríguez, M.; Tamayo, J. A. Chiral building-blocks by chemoenzymatic desymmetrization of 2-ethyl-1,3-propanediol for the preparation of biologically active natural products. Tetrahedron: Asymmetry 1999, 10, 449-455.

221. Barton D. H. R.; Jang, D. O.; Jaszberenyi, J. C. Hypophosphorous acid and its salts: New reagents for radical chain deoxygenation, dehalogenation and deamination. Tetrahedron Lett. 1992, 33, 5709-5712.

222. Hochlowski, J. E; Coll, J. C.; Faulkner, D. J.; Biskupiak, J. E.; Ireland, C. M.; Zheng, Q.; He, C.; Clardy, J. Novel metabolites of four Siphonaria species. J. Am. Chem. Soc. 1984, 106, 67486750.

223. Paterson, I.; Chen, D. Y.-K.; Franklin, A. S. Total synthesis of siphonarin B and dihydrosiphonarin B. Org. Lett. 2002, 4, 391-394.

224. Paterson, I.; Goodman, J. M.; Lister, M. A.; Schumann, R. C.; McClure, C. K.; Norcross, R. D. Enantio- and diastereoselective aldol reactions of achiral ethyl and methyl ketones with aldehydes: the use of enol diisopinocamphenylborinates. Tetrahedron 1990, 46, 4663-4684.

225. Narasaka, K.; Pai, F. C. Stereoselective reduction of $\beta$ hydroxyketones to 1, 3-diols highly selective 1,3-asymmetric induction via boron chelates. Tetrahedron 1984, 40, 2233-2238.

226. Takai, K.; Taghashira, M.; Kuroda, T.; Oshima, K.; Utimoto, K.; Nozaki, H. Reactions of alkenylchromium reagents prepared from alkenyl trifluoromethanesulfonates (triflates) with chromium(II) chloride under nickel catalysis. J. Am. Chem. Soc. 1986, 108, 6048-6050.

227. Jin, H.; Uenishi, J.-I.; Christ, W. J.; Kishi, Y. Catalytic effect of nickel(II) chloride and palladium(II) acetate on chromium(II)-mediated coupling reaction of iodo olefins with aldehydes. J. Am. Chem. Soc. 1986, 108, 5644-5646.

Sample Availability: Not available

(C) 2008 by the authors; licensee Molecular Diversity Preservation International, Basel, Switzerland. This article is an open-access article distributed under the terms and conditions of the Creative Commons Attribution license (http://creativecommons.org/licenses/by/3.0/). 